SANDRA NEVES ABDO

\title{
FERNANDO PESSOA: POETA CÉTICO?
}




\title{
FERNANDO PESSOA: POETA CÉTICO?
}

\author{
Tese apresentada ao Programa de Doutorado em Literatura \\ Portuguesa da Faculdade de Filosofia, Letras e Ciências \\ Humanas da Universidade de São Paulo, como requesito parcial \\ à obtenção do título de Doutor em Literatura Portuguesa. \\ Área de concentração: Literatura Portuguesa \\ Orientadora: Profa. Dra. Maria Helena Nery Garcez \\ Universidade de São Paulo
}

São Paulo

Faculdade de Filosofia, Letras e Ciências Humanas da USP

Departamento de Letras Clássicas e Vernáculas 


\section{AGRADECIMENTOS}

À Profa. Dra. Maria Helena Nery Garcez, pelos conselhos valiosos, pelo interesse e amizade com que sempre se dispôs a me orientar.

Às Profas. Dras. Aurora Fornoni e Raquel de Souza Ribeiro, pelas oportunas sugestões.

A Hermínio Carlos de Almeida, pelo incentivo, carinho e compreensão.

A todos que me apoiaram ao longo desse tempo. 
A meus pais

Salomão Abdo (em memória) e

Dalva Neves Abdo 


\section{SUMÁRIO}

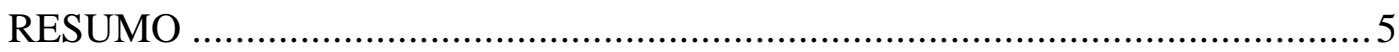

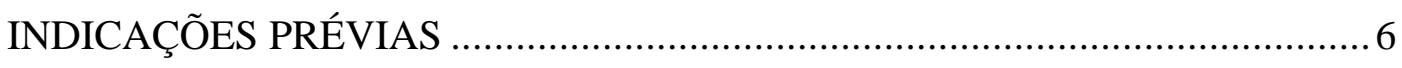

INTRODUÇÃ

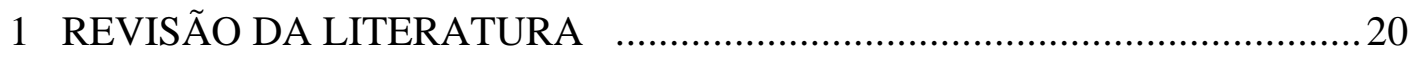

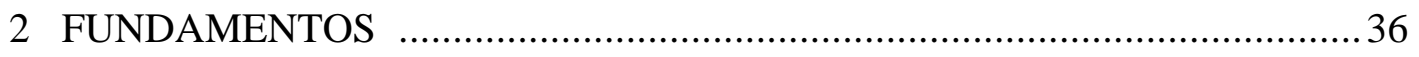

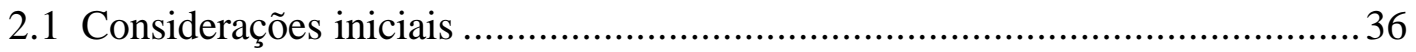

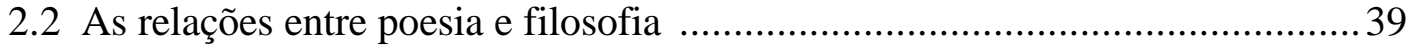

2.3 As poéticas novecentistas: alcance ontológico ….....................................52

2.4 Pareyson: estética e "ontologia hermenêutica" ................................................56

2.5 A filosofia cética: do pirronismo ao relativismo novecentista ......................70

3 A POÉTICA PESSOANA: diretrizes estilísticas e filosóficas ........................ 89

3.1 Fernando Pessoa: “...um poeta estimulado pela filosofia...” ..........................8 89

3.2 A poesia pessoana e a "crise da razão" .................................................... 94

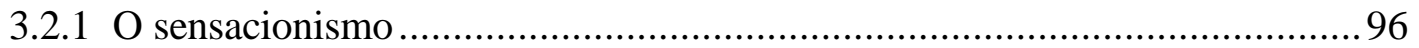

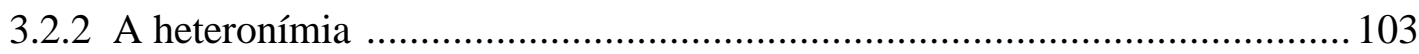

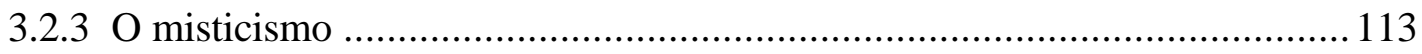

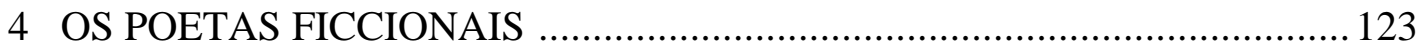

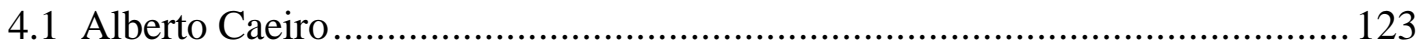

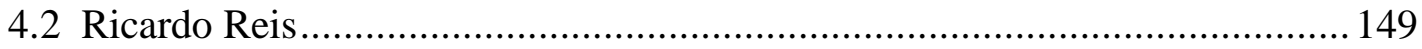

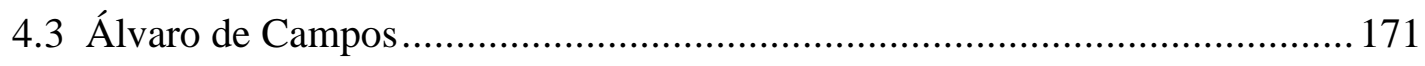

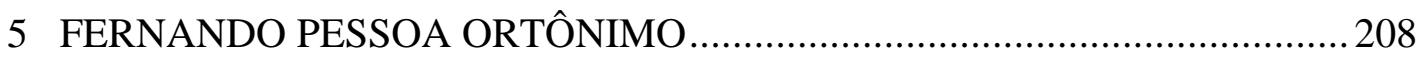

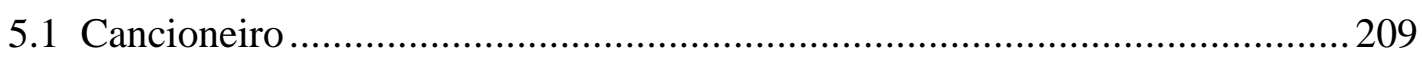

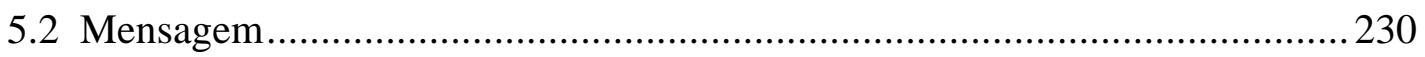

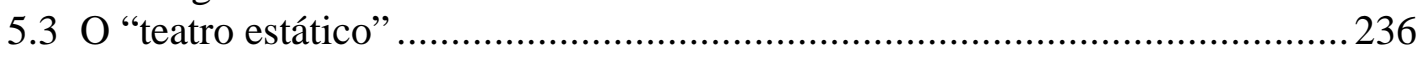

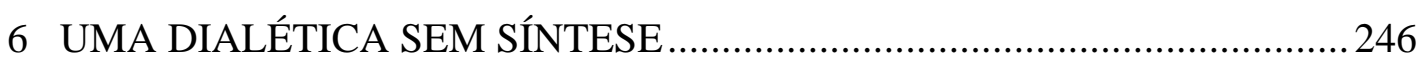

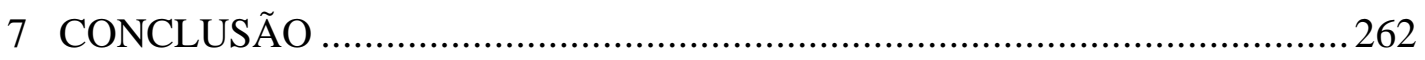

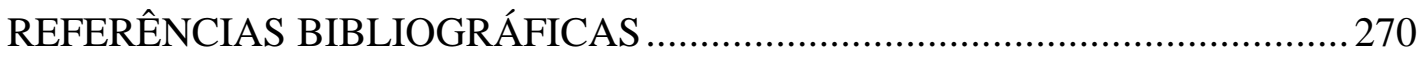




\section{RESUMO}

Este trabalho é uma reflexão sobre o alcance filosófico da poesia de Fernando Pessoa. Seu pressuposto fundamental é a idéia de que o significado primeiro dessa poesia, como de toda legítima poesia, desenvolve-se no nível de suas formas. A análise textual mostrou-se, assim, um procedimento decisivo, permitindo apontar a polifonia como princípio construtivo fundamental, pelo qual Fernando Pessoa faz um discurso poético essencialmente dubitativo, inquisitivo, suspensivo, uma verdadeira epoché cética.

Palavras-chave: modo de formar; heteronímia; polifonia; intertextualidade; ceticismo.

\section{RESUME}

Ce travail est une réflexion sur la portée philosophique de la poésie de Fernando Pessoa. Son présuposé fondamental est l'idée que le sens premier de cette poésie, comme tutte poésie légitime, se développe au niveau de ses formes. L'analyse textuelle s'est révelée une procédure décisive qui permet de signaler la polyphonie en tant que principe constructif fondamental, par lequel Fernando Pessoa fait un discours poétique essentiellement dubitatif, interrogatif, suspensif, une véritable époche sceptique.

Palavras chave: façon de former; hétéronyme; polyphonie; intertextualité; scepticisme 


\section{INDICAÇÕES PRÉVIAS}

1. Os poemas ortônimos e heterônimos de Fernando Pessoa são citados de:

PESSOA, Fernando. Obra poética. 7. ed. Rio de Janeiro: Nova Aguilar, 1977. (Organização, Introdução e Notas de Maria Aliete Galhoz).

Assinalo em notas de rodapé algumas divergências mais significativas, apresentadas pelas seguintes Edições Críticas:

PESSOA, Fernando. Poemas de Ricardo Reis. Lisboa: Imprensa Nacional / Casa da Moeda, 1944. (Edição Crítica organizada por Luís Fagundes Duarte).

PESSOA, Fernando. Álvaro de Campos. Livro de versos. 3. ed. Lisboa: Editorial Estampa, 1997. (Edição crítica organizada por Teresa Rita Lopes: introdução, transcrição, organização e notas).

PESSOA, Fernando. Mensagem. Poemas Esotéricos. Espanha: Archivos / CSIC, 1993. (Edição Crítica coordenada por José Augusto Seabra).

2. Na citação dos poemas uso como referência a numeração indicada entre colchetes, conforme consta da edição da Nova Aguilar.

3. As citações de textos em prosa de Fernando Pessoa são extraídas de:

PESSOA, Fernando. Obras em prosa. Rio de Janeiro: Nova Aguilar, 1995. (Organização, Introdução e Notas de Cleonice Berardinelli).

4. Nas citações de poemas não utilizados na íntegra uso (...), no início e no fim.

5. De modo geral, o formato das citações, notas e referências bibliográficas segue as normas da ABNT, levando em consideração a revisão da NBR-6023. Para maior clareza, no caso dos textos heterônimos, utilizei nas notas bibliográficas de rodapé o seguinte formato: (PESSOA-CAEIRO); (PESSOA-REIS); (PESSOACAMPOS). 


\section{INTRODUÇÃO}

Investigar o alcance filosófico da poesia, ortônima e heterônima, de Fernando Pessoa é tarefa complexa, que evidentemente não pode se limitar a um estudo tangencial, a um simples levantamento das leituras do poeta sobre este ou aquele filósofo, sobre esta ou aquela corrente de pensamento que o teria inspirado, nem tampouco pode se restringir à análise de temas, idéias e imagens presentes em seus poemas. Além do inconveniente de que tal metodologia confina no conteudismo estético, perdendo de vista o que há de mais essencial na concepção poética de Fernando Pessoa, há que se pesar o fato de que, em sua poesia, como, aliás, em toda grande poesia, a filosofia é um componente coessencial e profundo, que não apenas atua externamente, fecundando e revigorando a vibração emotiva e a intencionalidade formativa, mas com estas se consubstancia inteiramente, compondo uma trama orgânica coerente e indestrinçável.

Requer-se, pois, o respaldo teórico de uma estética que de fato fundamente o trabalho de busca do significado filosófico no próprio traçado físico da forma poética, possibilitando desse modo, não apenas a consideração de temas e assuntos, mas, igualmente, a das mais discretas inflexões formais como detentoras de profundos significados.

Daí a escolha da teoria da formatividade, de Luigi Pareyson (1918-1991), como pressuposto básico desta investigação. 
Publicada pela primeira vez em 1954 e, desde então, consagrada como um clássico da estética pós-croceana, notabiliza-se essa teoria pelo reconhecimento da forma artística como um organismo, ou seja, como um todo orgânico autônomo, indivisível, que goza de vida própria e legalidade intrínseca, e constitutivamente aberto a uma inesgotável interpretabilidade. Em outras palavras, trata-se de uma estética que tem como eixo a convicção de que, no processo interpretativo, é preciso estender “... o dever e a capacidade de exprimir e de significar a todos os aspectos da obra, dos assuntos aos temas, das idéias aos valores formais ...", considerando-os, todos, em sua unidade indissolúvel, enquanto “... igualmente resultantes dos gestos operativos do estilo." 1

Saliente-se, além disso, um outro aspecto, talvez o mais decisivo da estética pareysoniana e que se revela sobremodo pertinente para a presente investigação: o tratamento abrangente que a mesma concede à arte, explicando-a em sua indivisibilidade, sem perder de vista, em momento algum, a íntima conexão que unifica os seus três momentos fundamentais: o processo formativo, a forma acabada e as infinitas reações interpretativas e fruitivas a que a mesma se abre.

Como se verá mais à frente, o reconhecimento da unidade desses três momentos leva a dois outros reconhecimentos axiais: o do caráter essencialmente "fundante", processual e interpretativo da arte e, por conseguinte, o da necessidade de uma explicação que contemple essa sua natureza plena e não se centralize na mera busca dos seus "fundamentos" (filosóficos, históricos, estilísticos, sociológicos etc.). Não é que a explicação de tais "fundamentos" seja, de per si, inútil ou condenável. A

1 PAREYSON, 1997. p.63. 
questão é que ela não pode contemplar aquele alcance essencialmente "originário", "fundante", do discurso poético, quer dizer, o seu constituir-se como uma origem, logo como instituição e fundação de um novo significado, algo que antes não era e que agora passa a existir de um modo novo e irrepetível. ${ }^{2}$

Pesou, na escolha de Luigi Pareyson, a nossa longa experiência, minha ${ }^{3}$ e de minha Orientadora, Profa. Maria Helena Nery Garcez ${ }^{4}$, com a sua teoria da formatividade, bem como a nossa concordância quanto à sua fecundidade no estudo das vivas exigências postas pela poesia.

À luz do respaldo teórico oferecido por Pareyson, impôs-se investigar a dimensão filosófica da poesia pessoana, não como um significado externo a que ela remeteria e que exigiria ser resgatado para que se alcançasse uma adequada compreen-

\footnotetext{
${ }^{2}$ A propósito, Cf. especialmente: PAREYSON, 1988. p. 57-8, onde o filósofo reivindica de modo mais explícito a originariedade e ontologicidade da forma poética. Cf. também VATTIMO, 1985, cap. I.

${ }^{3}$ A estética de Pareyson foi tema de minha Dissertação de Mestrado em Filosofia, "A autonomia da arte na estética da formatividade", orientada pela Profa. Dra. Maria Helena Nery Garcez (UFMG, 1992). Desde então, mantenho contato intensivo com os escritos deste filósofo, aplicando-o em trabalhos diversos e divulgando-o através de traduções: "Filosofia da liberdade" (1996) e "A estética de Kant" (no prelo); comunicações: "A autonomia da arte na estética da formatividade" (1993), "Arte e condicionamento histórico-social na estética da formatividade" (1994), "Verdade e interpretação em Pareyson" (1996); artigos: "Arte e historicidade na estética de Pareyson" (1995), "Restauro artístico e suas implicações hermenêuticas" (1996), "Filosofia e história: um falso conflito" (1997), "Execução/interpretação musical: uma abordagem filosófica" (2000); seminários: "A estética de Luigi Pareyson" (USP, 1998); orientação da Dissertação de Mestrado em Filosofia: "Forma e formatividade em Luigi Pareyson: a formação do objeto artístico contemporâneo", defendida por Ronaldo Campos (UFMG, 1999).
}

4 Além de tradutora do primeiro livro de Luigi Pareyson publicado no Brasil — "Os problemas da estética" (1984; 2ed. 1989; 3ed.1997) — , a Profa. Dra. Maria Helena Nery Garcez é pioneira na aplicação dessa estética à leitura de Fernando Pessoa: Cf., especialmente, "Alberto Caeiro: 'Descobridor da Natureza'?" (1985), "Trilhas em Fernando Pessoa e em Mário de Sá-Carneiro" (1989) e "O tabuleiro antigo" (1990). É de interesse registrar que a citada professora já aplicava a teoria de Luigi Pareyson na preparação de sua tese para o concurso de professor livre-docente na Faculdade de Filosofia, Letras e Ciências Humanas da Universidade de São Paulo (1981). Desenvolve, atualmente, pesquisa sobre o gênero épico, na Antigüidade, Renascença e Época Moderna (privilegiando o diálogo entre Luís de Camões e Fernando Pessoa), sobre a "modernidade" portuguesa, desde poetas simbolistas como António Nobre e Camilo Pessanha aos poetas de "Orpheu", mormente Fernando Pessoa e Mário de Sá-Carneiro. Coordena, atualmente, um grupo de trabalho, na USP, sobre a estética e a filosofia da interpretação, de Luigi Pareyson. 
são, mas, antes, como um significado imanente, patenteado, de maneira singular e irredutível, no próprio modo como a forma poética se configura e pelo qual esta se propõe, num só ato, como documento de seus antecedentes e origem de infinitos desenvolvimentos e fruições, logo, como fundação de um novo ser.

De certo, isto não me impediu de pinçar temas ou enunciados, isolando-os, momentaneamente, para fins de análise, mas obrigou-me a não perder de vista o acento novo e inconfundível que estes adquirem dentro da organicidade poética de onde são extraídos.

Quanto aos antecedentes, terei por critério não colhê-los enquanto externos e meramente subsidiários da poesia, mas investigando sempre em que medida eles se tornaram constitutivos e participantes do conjunto orgânico e processual que é a obra de Fernando Pessoa. Como bem adverte Mikhail Bakhtin, "Entendida corretamente, a forma artística não formaliza um conteúdo já encontrado e acabado mas permite, pela primeira vez, percebê-lo e encontrá-lo., ${ }^{, 5}$ E como bem alerta Benedito Nunes, esse tipo de atenção é fundamental para quem não quer incorrer numa pretensa Crítica Filosófica, fundada na instrumentalização de conceitos e na consideração da obra como ilustração de alguma doutrina, equívoco este bastante comum no meio filosófico - e que ele próprio, Benedito Nunes, confessa ter cometido, num escrito anterior, ao tratar como ilustração do existencialismo sartreano a obra ficcional de Clarice Linspector. ${ }^{6}$

\footnotetext{
${ }^{5}$ BAKHTIN, 1997. p.45.

${ }^{6}$ NUNES, 1993. p.197-8. Transcrevo a passagem: "Eis o parco rendimento — ou rendimento nulo? — da Crítica desenvolvida como paráfrase filosófica. A ficção mesma da romancista, com seus procedimentos peculiares, da construção dos personagens ao aparato de sua linguagem, segundo a ligação caraterística entre a história e o discurso que nessa ficção se efetua - tudo isso, que é propriamente literário, era como que suprimido e eliminado em proveito do 'substrato filosófico' da narrativa. Nos estudos posteriores, pude, felizmente, corrigir essa distorção...”.
} 
Para a formulação da hipótese central, fundamentei-me primordialmente na leitura da obra poética, ortônima e heterônima, de Fernando Pessoa. Conforme esclareci nas Indicações Prévias, não me empenhei na leitura exaustiva das edições críticas da obra de Fernando Pessoa. Tomei conhecimento, é claro, a conselho de minha Orientadora, das principais polêmicas, como, por exemplo, a que Teresa Rita Lopes desenvolve em "Álvaro de Campos: Livro de versos”, contra “omissões”, “imprecisões", "correções" e "intervenções cirúrgicas" (enxertos de variantes e colagens) que ela atribui a Cleonice Berardinelli ("Poemas de Álvaro de Campos"). Mas, na medida do possível, procurei não entrar no mérito desta e de outras polêmicas.

Ao longo dessa leitura dos textos poéticos pessoanos, chamou-me especial atenção o caráter eminentemente polifônico de todo esse formidável construto. Alberto Caeiro, Ricardo Reis, Álvaro de Campos e Fernando Pessoa ortônimo pareceram-me, desde o primeiro instante, "vozes" independentes e contrastantes, unidas contudo pela trama de um dialogismo constante e multipolar, verificável, primeiramente, no plano interno de seus discursos individuais (pondo-os em relação permanente com tradição filosófica e poética), e além disso, no nível externo ou global dessa poética.

Pareceu-me de pronto que, ao contrário do que entendem alguns críticos, essa dialética não tem por base um modelo de movimento triádico e progressivo, do tipo hegeliano, mas antes se apresenta, tanto num nível quanto no outro, como um dialogismo sem síntese, que funde e identifica os contrários, instaurando paradoxos, sentidos dúbios e contradições insolúveis, sem direcionamento para uma síntese final. No nível interno dos poemas, chamaram-me especial atenção os recursos diversos — tais como metáforas, desenhos oximorescos e outras figuras retóricas ou estilísticas —, 
pelos quais os mesmos constróem o seu sentido favorecendo ou recriando uma característica atmosfera de ambigüidade e incerteza, em que erro e verdade, saber e nãosaber, configuram-se como valores equivalentes e permutáveis, minando toda pretensão de conhecimento verdadeiro.

Com o propósito de averiguar até que ponto o procedimento acima é consciente e programático em Fernando Pessoa, consultei, paralelamente ao exame dos seus textos poéticos, os pertencentes à sua produção no campo da crítica e da teoria literária.

Nesse sentido, fui analisando os depoimentos e comentários por ele deixados. É claro, com a cautela devida de não acolhê-los de modo desprevenido - e isto não tanto por serem de alguém declaradamente afeito à simulação (uma tendência orgânica e constante, segundo ele), mas, mais precisamente, porque, com freqüência, são fragmentos teóricos bastante distanciados no tempo e que, além disso, nem sempre correspondem ao seu pensamento pessoal, destinando-se, muitas vezes, ao delineamento filosófico de algum de seus heterônimos ou semi-heterônimos.

Pesadas estas ressalvas, devo dizer que, conquanto me interesse mais diretamente o que se concretiza no plano poemático, e não o que o autor defende no plano pessoal, algumas dessas passagens (em sua maioria extraídas da célebre carta de 11 de dezembro de 1931, a João Gaspar Simões) se mostraram especialmente instigantes, não como comprovação, é claro, mas como reforço de algumas das intuições suscitadas pela leitura de Fernando Pessoa.

Destaco, especialmente, as seguintes passagens:

"O ponto central da minha personalidade como artista é que sou um poeta dramático [...]. Desde que o crítico fixe [...] que sou essencialmente poeta dramático, tem a chave da minha personalidade, no que pode interessá-lo a 
ele, ou a qualquer pessoa que não seja um psiquiatra, que, por hipótese, o crítico não tem que ser. Munido desta chave, ele pode abrir lentamente todas as fechaduras da minha expressão. Sabe que, como poeta, sinto; que, como poeta dramático, sinto despegando-me de mim; que, como dramático (sem poeta), transmudo automaticamente o que sinto para uma expressão alheia ao que senti, construindo na emoção uma pessoa inexistente que a sentisse verdadeiramente, e por isso sentisse, em derivação, outras emoções que eu, puramente eu, me esqueci de sentir",

“... são atitudes literárias, sentidas intensamente por instinto dramático, quer as assine Álvaro de Campos quer as assine Fernando Pessoa",

“... é sério tudo o que escrevi sob os nomes de Caeiro, Reis, Álvaro de Campos. Em qualquer destes pus um profundo conceito de vida, divino em todos três, mas em todos gravemente atento à importância misteriosa de existir", ;

a obra de cada heterônimo forma “... uma espécie de drama; e todas elas juntas formam outro drama... "10.

Há, nesses depoimentos de Fernando Pessoa, alguns aspectos que, em consonância com as intuições já suscitadas pela leitura poética, parecem-me dignos de especial atenção.

Antes de mais nada, é preciso atentar à sua insistência (não só aqui, mas em vários outros momentos de sua obra em prosa) em se auto-definir como um poeta dramático, que sente e escreve na pessoa de outro, mesmo quando apõe sua própria assinatura a seus escritos. Segundo me parece, essa insistência tem uma importância capital dentro de sua poética, na medida em que, por meio dela, o poeta está a sinalizar o caráter dialógico do seu discurso, ou seja, o fato de que, em cada texto, ortônimo ou heterônimo, malgrado as características que asseguram o seu perfil próprio, ressoa uma

\footnotetext{
${ }^{7}$ PESSOA, 1995. p.67.

${ }^{8}$ PESSOA, 1995. p.65.

${ }^{9}$ PESSOA, 1995. p.55.

${ }^{10}$ PESSOA apud GARCEZ, 1985. p.10.
} 
interdiscursividade constitutiva, coessencial, pela qual, há que se considerá-los sempre em recíproco confronto, nunca isoladamente. Nesse sentido, é válido dizer que “... a poesia pessoana é um espaço sempre habitado por um outro: uma outra palavra, um outro discurso, na medida em que cada texto heteronímico assume os demais textospersonagens como a voz outra instauradora de sua fala."11

No que se refere à terceira passagem, as menções à "seriedade" de tudo o que está escrito sob os nomes dos heterônimos, ao "profundo conceito de vida" que cada um deles representa e à sua atenção para com a "importância misteriosa de existir", confirmam a profundidade filosófica que o próprio Fernando Pessoa consigna a todo esse espaço ficcional.

Na quarta passagem, é significativo o alerta quanto à existência de dois significados: um significado individual da produção de cada heterônimo e outro que se constitui no nível global (incluindo-se aí também o ortônimo, já que este, de acordo com o segundo trecho acima transcrito, é também uma "atitude literária").

A respeito, entendo que, primeiramente, a menção a um drama global não supõe obrigatoriamente a idéia de integração ou conciliação das perspectivas diversas em um ponto de vista unificado, podendo perfeitamente acolher a idéia de um sentido global, que tenha por base a manutenção das diferenças. Além disso, o termo "drama" alude aqui não só ao caráter representativo, mimético, construído, do contexto heteronímico, mas igualmente ao seu caráter dialógico, o que dá uma ênfase especial ao caráter polifônico de todo o contexto. Resumindo, há, com efeito, um drama Caeiro, um drama Reis, um drama Campos, que, em conjunto, compõem um outro drama. E há, por

\footnotetext{
${ }^{11}$ SEGOLIN, 1992. p.142.
} 
outro lado, a poesia ortônima que, mesmo possuindo um estatuto próprio, não identificável com o da poesia heterônima, é igualmente sentida "por instinto dramático", o que autoriza incluí-la na composição do sentido global, sinalizado por Fernando Pessoa. Pesando todos esses aspectos, parece-me mais profícuo pensar o sentido global da poesia pessoana à luz do conceito de polifonia.

Isto me leva a assim enunciar a hipótese central de meu trabalho:

— considerando que, no plano de sua obra individual, Fernando Pessoa ortônimo e os heterônimos Alberto Caeiro, Ricardo Reis e Álvaro de Campos ${ }^{12}$ constituem mundos poéticos singulares, organicamente permeados por uma tensão dialógica sem conciliação;

— considerando, além disso, que, no plano global da poética pessoana, todos eles juntos compõem um contexto polifônico e dialógico, cujas vozes se entrelaçam numa contrastação permanente, algumas vezes aparentando conciliar-se, mas de fato mantendo-se irredutíveis em seu jogo dubitativo, suspensivo e inquisitivo, dissolvendo toda pretensão de saber verdadeiro;

— é justo inferir que o significado global desse conjunto poético não está a solicitar tratamentos totalizantes, conciliantes e unificadores, do tipo preconizado pela aplicação do modelo reflexivo hegeliano, mas, antes, um tratamento não sintetizador,

\footnotetext{
12 Segundo o próprio Fernando Pessoa, são esses os seus verdadeiros heterônimos. Os demais personagens por ele inventados seriam, ou "semi-heterônimos" (por exemplo, Bernardo Soares, que dele se distingue pelas idéias, sentimentos e visão de mundo, mas não pelo estilo), ou simples "personalidades literárias". Note-se que Bernardo Soares é apresentado, ora como semi-heterônimo - "É um semiheterônimo porque, não sendo a personalidade a minha, é, não diferente da minha, mas uma simples mutilação dela. Sou eu menos o raciocínio e a afetividade" (PESSOA, 1995. p.98) - ora como uma personalidade literária - “... o B. S. não é um heterônimo, mas uma personalidade literária”, escreve em carta a Gaspar Simões, datada de 28/07/1932. (PESSOA, 1995. p.465).
} 
que resguarde a sua irredutibilidade dialógica e o seu sentido essencialmente dubitativo, inquisitivo e suspensivo. Tal modelo reflexivo, penso eu, pode ser buscado na epoché da filosofia cética.

Esta hipótese, obviamente, não é um pressuposto absoluto, uma chave semântica que pretenda deslindar de uma vez por todas o mistério pessoano (coisa impossível, evidentemente). É antes, um ponto de partida, sempre passível de revisão e aprofundamento, para um diálogo crítico e interativo com discurso poético do autor, tentando iluminá-lo sob um certo ponto de vista, mas cuidando de respeitá-lo na sua riqueza intrínseca e inesgotável.

É natural que, devido ao tipo de modelo reflexivo utilizado, esta investigação chegue a resultados contrastantes com os de outras conhecidas, sobretudo daquelas que, de uma forma ou de outra, tentam conciliar ou "resolver" a polifonia pessoana. Em princípio, esta diversidade de interpretações não nos coloca num terreno de recíproca exclusão. Como explicarei adiante, à luz dos fundamentos pareysonianos deste trabalho, se o processo interpretativo é continuamente aprofundável, isto não se deve a uma forçosa insuficiência ou parcialidade de cada uma das leituras, mas, antes, à natureza plurissêmica e inexaurível do próprio objeto investigado. Quer dizer: para que uma leitura seja válida, não é preciso supor que todas as demais sejam erradas, nem tampouco concluir que sejam todas igualmente "corretas", caindo assim naquele indiferenciamento hermenêutico tão ao gosto de certas correntes hodiernas. ${ }^{13}$ Ademais, vale sempre lembrar que a meta da interpretação não é a explicitação de um significado unívoco, nem a entrega do processo a um indiferente fluir de possibilidades, carentes de

\footnotetext{
13 Refiro-me àquela corrente hermenêutica que, com propriedade, Gianni Vattimo chama de “...
} ermeneutica del 'tutto và' ...". (VATTIMO, 1993. p.6). 
critério. A interpretação é plural, mas não arbitrária, pois tem uma lei reguladora, a própria obra, que, como critério interno, atua como parâmetro das reações diversas à sua plurissemanticidade inesgotável.

De acordo com alguns críticos e comentadores, é uma empresa vã tentar identificar o significado da obra poética de Fernando Pessoa: seja devido à morte prematura do poeta, antes de imprimir à sua obra uma organização mais definida, seja devido ao fato de ainda não se conhecer a totalidade dos seus escritos, não se poderia falar de um significado global. Antecipando-me a esse tipo de objeção, gostaria de ponderar que, à parte o fato de que já veio à luz o fundamental da obra pessoana, é preciso ter em conta que a impossibilidade de se falar de um significado definitivo é algo que diz respeito a toda legítima obra poética, e não apenas à de Fernando Pessoa. A infinitude da poesia não é algo que se deve a circunstâncias acidentais, mas é, antes, uma característica fundamental, que remete ao próprio modo de ser do seu discurso, que, como tal, é constitutivamente "aberto", inexaurível, fonte inesgotável de significados. É claro que estou a falar aqui da infinitude essencial da obra poética, em geral, acrescentando-se a esta ponderação o fato de que a poesia de Fernando Pessoa pertence àquela classe de produções, intencionalmente construídas de modo a provocar essa riqueza de sugestões e provocações.

Ademais, poder-se-ia perguntar: o desconhecimento da totalidade dos escritos de um autor pode constituir um impedimento para a sua compreensão?

Há ensinamentos deixados por Luigi Pareyson, em sua estética, que podem ser úteis para a resposta a esta pergunta. 
Diz o filósofo, desenvolvendo reflexões inspiradas em Aristóteles, que o todo precede às partes, não sendo estas que o possibilitam, mas exatamente o inverso, o que significa que, de um lado, a totalidade resulta da unidade das partes; do outro, essa totalidade é, ao mesmo tempo, anunciada e desejada por cada parte conhecida. Em outras palavras, sendo a obra de arte completa e conclusa, suas partes não constituem um aglomerado, mas formam um todo indivisível, constituindo, nessa sua unidade, a própria forma. Esta, por sua vez, não é apenas um todo que resulta do conjunto de suas partes, mas, essencialmente, um todo contido e evocado por cada uma delas. Assim sendo, todas as partes são essenciais, indispensáveis. Se, em certos momentos, alguma parte parece menos importante, isto se deve a uma distribuição interna de funções, em obediência às exigências do todo, e não ao fato de que sua contribuição à instauração do inteiro seja menor.

Por outro lado, acidentais "inacabamentos" não comprometem a "unitotalidade" da forma, pois a sua consumação já vem indicada, como fim a ser alcançado, precisamente por aquele todo que já vive dinamicamente ao longo do processo de formação. Se a totalidade da obra fosse estática, aí sim, um simples defeito romperia a sua unidade e destruiria o todo, impossibilitando a interpretação. ${ }^{14}$ Assim sendo, o fato de não serem conhecidos todos os escritos de Fernando Pessoa não é impedimento para

\footnotetext{
${ }^{14}$ Vale lembrar que, se não houvesse possibilidade de reconstruir as partes danificadas com base nas existentes, a arte da restauração seria inviável. O que assegura esse procedimento, mesmo em face do caráter inventivo do processo, é a possibilidade de se descobrir a lei que governa a obra e que confere coerência e unidade ao todo, ou, como diz Umberto Eco, a possibilidade de se inferir "o código gerador das partes que faltam e são adivinhadas" através do "código que se delineia, ao nível dos extratos ainda perceptíveis". (ECO, 1971. p. 58).
} 
a compreensão do significado de sua obra. Sempre é possível "adivinhar" o todo, mesmo quando algumas partes são desconhecidas. ${ }^{15}$

${ }^{15}$ Cf. PAREYSON, 1991. p.106 et seq. 


\section{REVISÃO DA LITERATURA CRÍTICA}

Sobre a obra poética de Fernando Pessoa debruçam-se críticos, comentadores, ensaístas, teóricos das mais diversas áreas, num incansável esforço de exegese. Levantam antecedentes, descobrem novos fragmentos, esboços, rascunhos, projetos operativos inacabados, vasculham íntimas motivações, dissecam minúcias do traçado estilístico, conferindo sempre um singular realce a um ou outro aspecto. Ora o foco é o processo criativo, ora a forma acabada, ora o influxo contextual, ora a herança estilística, ora as motivações internas do poeta. Por vezes, parece não haver mais nada a dizer ou a descobrir. Mas, a cada dia, surge uma nova tese, um novo ensaio crítico, desvelando ou enfatizando novos ângulos, numa sucessão interminável de leituras e releituras.

Essa infinidade interpretativa, em princípio, nada tem de negativo ou surpreendente, antes, é algo positivo e mais que esperável: tratando-se da compreensão de um discurso poético, logo, de um discurso sabidamente ambíguo e auto-reflexivo (um discurso que atrai a atenção do destinatário primordialmente para o modo como está elaborado, permitindo e estimulando várias decodificações) ${ }^{1}$, a sua infinita interpretabilidade realiza possibilidades inerentes à sua própria forma. Não é, em suma, uma ocorrência acidental, mas, antes, um fato definitivo, porque constitutivo do próprio modo de ser da obra de arte.

\footnotetext{
${ }^{1}$ Cf. ECO, 1971. p. 51-7.
} 
Na verdade, nem haveria necessidade desse comentário, se não fosse a persistência, em certa hermenêutica hodierna, de um lado, da falácia da completude; do outro, do pressuposto simplista de que a infinidade interpretativa é simples conseqüência da variedade subjetiva das acepções. Nos dois casos, ocorre um lamentável desconhecimento da natureza plurívoca da obra de arte e do processo mesmo da interpretação, o qual, como recorda Luigi Pareyson, é sempre pessoal, mas não necessariamente subjetivo: o seu critério diretivo é a própria obra, infinita em seus aspectos, com a qual a pessoa deve sintonizar, e não o ponto de vista dessa pessoa. Mais à frente, na explicação dos conceitos estéticos pareysonianos, retomo essa idéia. Por ora, quero apenas assinalar que o reconhecimento da igual plausibilidade de várias interpretações não implica a admissão de um indiferente fluir de possibilidades, carentes de critério. O processo interpretativo é infinito, mas não no sentido de que se entrega apenas ao arbítrio do leitor. A própria obra é a sua lei, não como um dado objetivo, obviamente, mas como lei que se exercita internamente a cada encontro. Tal critério, se por um lado não permite dizer qual interpretação é mais correta (pois cada avaliação só se dá dentro de alguma outra), por outro, permite apontar as equivocadas.

Ainda com referência a essa multiplicidade de leituras, é de se pesar um outro aspecto, a saber, o fato de que, tratando-se, aqui, de uma produção poética especial, reconhecidamente “... proteiforme, não apenas enquanto criação de uma pluralidade de linguagens, mas pelo seu apelo a uma pluralidade de leituras...”2, é perfeitamente esperável que a infinitude normal da palavra poética se apresente ainda mais acentuada, suscitando, por conseguinte, um considerável incremento da multiplicidade exegética.

\footnotetext{
${ }^{2}$ SEABRA, 1974. p.17.
} 
O objetivo desta revisão da literatura crítica sobre Fernando Pessoa não é oferecer uma relação exaustiva das análises realizadas por outros autores, mas resumir e comentar resultados alcançados por alguns desses estudos.

Começo pela linha das análises histórico-sociológicas, onde se destaca como conhecida referência o livro "Fernando Pessoa, poeta da hora absurda" (1958), de Mário Sacramento.

Seu pressuposto básico é, como já foi bastante discutido por outros críticos, uma direta equivalência entre poesia e contexto histórico-social, daí resultando um sensível comprometimento da avaliação propriamente literária da obra pessoana: a heteronímia acaba qualificada como um procedimento artificial, inautêntico, enfim, como uma mera tentativa, por parte de Fernando Pessoa, de adequar-se ao seu contexto histórico caótico - a "hora absurda".

Duas passagens servem para ilustrar o que acabo de comentar:

\begin{abstract}
"Ora em Fernando Pessoa o que logo (e sempre) nos punge é aquela solução tão por demais levianamente 'fácil' da heteronímia. Fácil, está claro, não porque destituída de talento (pois, ao invés, só foi possível mediante um talento que diremos 'excessivo'), mas porque tão comprazida em trilhar um caminho da mais descarnada artificiosidade."
\end{abstract}

"Perante o colapso do racionalismo idealista, Pessoa, racionalista não obstante, tem de substituir o culto da Razão pelo das razões da sem-razão da Razão (no sentido, não de razões-causa, que teriam podido libertá-lo, mas de razõessucedâneo ou razões na sem-razão e a despeito dela). Procurando subsistir, a vida depõe assim a vice-Razão do Desespero, e o-que-sente, agarrando pelos cabelos o-que-pensa, força-o a alienar-se no caos do absurdo."4

\footnotetext{
${ }^{3}$ SACRAMENTO, 1970. p.27-8. (Grifos do autor).

${ }^{4}$ SACRAMENTO, 1970. p.95. (Grifos do autor).
} 
Passando a uma outra linha analítica, a da crítica biográfico-psicanalítica, é forçoso citar, primeiramente, o livro "Vida e obra de Fernando Pessoa" (1950), de João Gaspar Simões.

Pioneiro nesse tipo de exegese da obra pessoana, o autor adota como pressuposto uma necessária e direta correspondência entre a poesia e a biografia de Fernando Pessoa, desenvolvendo esse pressuposto à luz de um "freudismo" um tanto radical. Daí resultam comentários como os que se seguem:

\begin{abstract}
"E o Fernando Pessoa de seis anos, que se julgara, durante, pelo menos, quase um ano — da morte do irmão, em janeiro de 1984, ao dia em que sua mão começou a preparar o enxoval para o seu segundo casamento, em fins desse mesmo ano - , de facto, para todo o sempre, 'o menino de sua mãe', sentindo que o não era, que o não podia continuar a ser, perdeu a ternura que tinha, tornando-se, talvez não 'cínico implacável', 'filho monstruoso do amor natal que se lhe negou', mas, pelo menos, frio mistificador, essa espécie de 'palco' impessoal, intemporal e abstracto, onde começa a representar-se o estranho drama da sua criação poética."
\end{abstract}

"Capaz de mentir, de fingir, de blaguear, de mistificar, no plano da vida; no plano da arte, pelo menos como Fernando Pessoa, ou enquanto Fernando Pessoa, centro verdadeiro da irradiação fictícia dos seus heterónimos — não o podia fazer. [...]. Quer dizer: os heterónimos, sendo, como são, uma mistificação, representam, afinal, na ética literária de Fernando Pessoa e na sua metafísica, uma das mais sérias manifestações de sinceridade de que ele foi capaz em vida. Por não saber harmonizar a sinceridade que a poesia exige com a insinceridade que viver implica é que Fernando Pessoa lançou mão, afinal, do expediente insincero dos heterónimos."

"É nesse ponto, contudo, que a sinceridade de Alberto Caeiro se nos apresenta condicionada, restrita, desumanizada. Sim, 'desumanizada'. Não podemos aceitar a sinceridade do autor dos Poemas Inconjuntos [...] no plano em que aceitamos a sinceridade de certos passos da poesia de Álvaro de Campos ou mesmo da do próprio Fernando Pessoa. E isto pela simples razão de que o nosso conceito de sinceridade — o conceito de sinceridade que a nós, crítico

\footnotetext{
${ }^{5}$ SIMÕES, 1987. p.53.

${ }^{6}$ SIMÕES, 1987. p.251.
} 
e biógrafo, importa — é outro: é o conceito de sinceridade que está na linha que liga a inspiração à vida, a criação à existência, a poesia à biografia."7

Como se sabe, já em 1931, esse tipo de leitura biográfica-psicanalítica motivara uma dura advertência do próprio Fernando Pessoa a João Gaspar Simões, recordando a este o seu dever, enquanto crítico, de ater-se ao artístico e não ao que pertence à vida pessoal do autor: o crítico, enquanto tal, não é psicólogo, sendo seu mister “... estudar o artista exclusivamente como artista, e não fazendo entrar no estudo mais do homem que o que seja rigorosamente preciso para explicar o artista". 8

No livro “A metáfora em Fernando Pessoa” (1973), de Maria da Glória Padrão, a obra de Fernando Pessoa é relacionada às experiências oníricas do poeta e “... outras tantas razões ora conscientes, ora inconscientes" ${ }^{\prime 9}$. Ao longo de seu trabalho, a autora perscruta o texto pessoano, examinando seus temas, enunciados e imagens poéticas à luz de conceitos extraídos de Freud, Jung, Bachelard; considera dados levantados por conhecidos biógrafos, como João Gaspar Simões, Armand Guibert, e até mesmo extraídos da correspondência pessoal do poeta. ${ }^{10}$ Daí conclui que metáforas recorrentes nessa poesia, tais como as da água, do mar, do rio, são reflexos do seu amor exacerbado pela mãe.

\footnotetext{
${ }^{7}$ SIMÕES, 1987. p.254.

${ }^{8}$ PESSOA, 1995. p.66. O motivo da reprimenda é o ensaio "O mistério da poesia", onde Gaspar Simões tece considerações psicanalíticas a seu respeito.

${ }^{9}$ PADRÃO, 1973. p.83.

${ }^{10}$ PADRÃO, 1973. p.94.
} 
As duas passagens abaixo exemplificam a linha argumentativa adotada pela

autora:

\begin{abstract}
"Mar humano ou mar místico, mar das travessias ou mar de 'ao pé do Fado' (Reis, 315), Pessoa tem por ele o respeito de quem o venera e a admiração de quem o enaltece. [...] Identificando essa verdade com a água e sentindo-se levado por ela, Pessoa franqueia a todos os olhares o amor que sempre teve a sua mãe. A crítica literária, desde que Freud divulgou as suas teorias do inconsciente, começou a alicerçar palavras e imagens no psiquismo do artista e esta tendência psicanalítica conduz-nos à afirmação acima enunciada: na água que aparece na obra de um autor, pode medir-se o grau de sentimento que o une à mãe." 11
\end{abstract}

"O simples facto de Álvaro de Campos escolher o mar para ilustrar uma determinada teoria poética, e não optar, por exemplo, pela tempestade a que se segue a calmaria ou por uma paisagem terrena de montanhas e vales, é só por si uma acusação: é o testemunho duma tendência inconsciente que Pessoa tem para eleger uma água que só é um espectáculo consciente depois de ter sido uma experiência onírica." 12

Tanto quanto pude observar, não são consideradas exigências internas do texto, que poderiam justificar a preferência por um ou outro termo, nem tampouco são aventadas outras hipóteses explicativas, igualmente plausíveis, por exemplo, a notória inspiração de Fernando Pessoa em Heráclito de Éfeso e seus conhecidos aforismos sobre os rios e o fluxo das águas.

Ao fim e ao cabo, fica a impressão de que, mais do que compreender a formidável estrutura poética de Fernando Pessoa, Maria da Glória Padrão quer compreender o homem Fernando Pessoa, seus desejos latentes, suas tendências inconfessas, seus

\footnotetext{
${ }^{11}$ PADRÃO, 1973. p.92.

12 PADRÃO, 1973. p.94.
} 
comportamentos excêntricos $^{13}$, tudo isto com base em uma possível correspondência entre seus temas e enunciados e os móveis inconscientes do seu poetar, reduzindo-se o valor da obra poética ao de veículo privilegiado para o extravasamento dessas instâncias inconscientes.

"Fernando Pessoa: aquém do eu, além do outro" (1982), de Leyla PerroneMoisés, é um estudo atento às peculiaridades do texto pessoano, porém direcionado para a compreensão do que, psicanaliticamente falando, o antecede e fundamenta.

À luz de conceitos lacanianos, a criação dos heterônimos aparece como uma decorrência de um transbordamento pulsional, que, não encontrando um "suporte subjetivo" adequado ("um ego que carregasse o excesso do desejo") se extravasaria gerando vários suportes, os vários "eus" representados pelos heterônimos. Cito a autora:

\begin{abstract}
"Multiplicar-se em vários eus não é, em Pessoa, a conseqüência de uma 'riqueza subjetiva', mas de uma falta subjetiva. [...] Pessoa teve de multiplicarse por falta de um ego que carregasse o excesso do desejo. Nele as pulsões estavam sem suporte subjetivo; como forças que são, as pulsões exigiram vazão e, ao abrirem-se as comportas, criaram não um, mas vários suportes. Por serem vários e 'reais' (filhos de múltiplos desejos), os suportes escaparam ao
\end{abstract}

\footnotetext{
${ }^{13}$ A propósito de comportamentos excêntricos, vale lembrar que estes nem sempre são meros sintomas de distúrbios mentais. Veja-se, por exemplo, algumas das tão faladas excentricidades de Fernando Pessoa tais como: andar pela rua sem se desviar de obstáculos, ir de encontro a postes etc.. (COELHO, A. P. 1971. p.27). Mesmo que tenham algo a ver com a sua decantada fragilidade mental, é preciso considerar outras possíveis explicações, dentre elas, o fato de que tais excentricidades coincidem literalmente com as atribuídas ao filósofo cético Pirro de Élis e que seriam decorrências de sua radical adesão aos princípios de sua doutrina. São atribuídos a Pirro de Élis comportamentos como: caminhar pelas ruas sem olhar e sem se esquivar de nada, afrontando toda sorte de obstáculos (Diógenes Laércio (IX, 61); deixar de socorrer um amigo caído acidentalmente num pântano, continuando seu caminho, como se nada tivesse acontecido (VERDAN, 1971. p.19). Isto nos coloca frente a uma possível inspiração de Fernando Pessoa nos comportamentos do filósofo helenista.
} 
ego, assumiram claramente sua condição de héteros, de comutadores alternantes." 14

Não pretendo aqui discutir a pertinência que esse caminho explicativo possa ter, seja para a compreensão do homem Fernando Pessoa, ou do psiquismo humano em geral, seja, como sugere a autora, para o esclarecimento da própria psicanálise. ${ }^{15}$ Quero apenas registrar que, conquanto se deva ressaltar a perspicuidade de muitas das análises e argumentos levantados, a relevância estética dos dados coletados é discutível. A propósito, a própria estudiosa tem consciência da diversidade dos caminhos e dos objetivos do psicanalista e do crítico literário. A psicanálise, ressalva ela, não explica o valor da arte, diante do qual “... o próprio Freud sempre se deteve”. ${ }^{16}$ Algumas linhas adiante:

\footnotetext{
“... o confronto do saber do Poeta com um saber científico (como aqui o estabeleci) revela que aquele não pode ser simplesmente submetido a este. A psicanálise não 'explica' Pessoa; Pessoa esclarece a psicanálise. Por isso, estas minhas observações tanto poderiam chamar-se 'Notas para uma leitura lacaniana de Pessoa' como 'Notas para uma leitura pessoana de Lacan'.,"17
}

“Os fundamentos filosóficos da obra de Fernando Pessoa” (1971), de António Pina Coelho, é uma menção obrigatória dentro da bibliografia empenhada em expor e interpretar as linhas filosóficas fundamentais da poesia pessoana.

\footnotetext{
${ }^{14}$ PERRONE-MOISÉS, 1990. p.89.

${ }^{15}$ PERRONE-MOISÉS, 1990. p.88-9.

${ }^{16}$ PERRONE-MOISÉS, 1990. p.88.

${ }^{17}$ PERRONE-MOISÉS, 1990. p.88-9.
} 
Ressalte-se aqui a seriedade dos levantamentos realizados, dentre os quais, inclui-se uma detalhada relação das leituras e interesses filosóficos do poeta. Mas, em boa medida, o texto poético fica reduzido a ilustração do pensamento filosófico, procedimento que se mostra especialmente inadequado quando aplicado a um poeta da estatura de Fernando Pessoa, onde os dois níveis — o poético e o filosófico — são rigorosamente inseparáveis: o ato de pensar já nasce com uma intencionalidade formativa e o ato de fazer poesia já é, ele próprio, filosofia. Dessa forma, sendo o filosófico interno ao próprio processo de configuração textual, com ele coincidindo inteiramente, é problemático isolá-lo e medi-lo pelo parâmetro de alguma doutrina.

Há uma terceira linha de análise, direcionada não para fatores extrínsecos, mas para o próprio texto poético. Como primeiro exemplo, cito o livro "Diversidade e unidade em Fernando Pessoa" (1949), de Jacinto do Prado Coelho.

Sua proposta é realizar “... uma crítica 'imanente', ou, se preferirem, estilística (isto é: dos motivos e das formas que a obra literária encerra)..."18, de modo a captar “... a unidade essencial implícita na diversidade das obras ortônimas e heterônimas”. ${ }^{19}$ Partindo de um cuidadoso levantamento dos nexos temáticos e estilísticos que permeiam as obras do ortônimo e de cada um de seus heterônimos-poetas, o autor visa comprovar que a diversidade heteronímica, sendo criação de um só autor, alicerça-se num denominador comum estilístico, que confere uma unidade subjacente às diferentes cosmovisões e pontos de vista. Esta tese recebe algumas críticas de José Augusto Seabra, cujos argumentos serão resumidos um pouco mais à frente.

\footnotetext{
${ }^{18}$ COELHO, J. P. 1977. p.14.

${ }^{19}$ COELHO, J. P. 1977. p.14.
} 
"Les oxymores dialectiques de Fernando Pessoa" (1968), é um estudo realizado por Roman Jakobson, em colaboração com Luciana Stegagno Picchio, e que se mostra mais estritamente direcionado para a crítica imanente.

Trata-se de uma microanálise, e não de um estudo compreensivo da obra pessoana. Seu foco de atenção é o poema "Ulysses", através do qual, os autores trazem à luz um princípio construtivo da maior importância na obra de Fernando Pessoa — o movimento oximoresco — , salientando, como indica o próprio título do ensaio, a sua natureza dialética.

Essa tese da dialeticidade dos oxímoros em Fernando Pessoa é criticada por José Augusto Seabra ${ }^{20}$, com base no argumento de que não se trata, no poema em apreço, de oxímoros dialéticos, mas de uma relação em que os valores opostos se fazem permutáveis, reversíveis, e não se fundem numa síntese dialética. A propósito, convém registrar que, em ensaio anterior, Benedito Nunes, discute essa questão, também negando a dialeticidade dos opostos na obra pessoana. ${ }^{21}$ Retomo esse ponto no curso de meu trabalho. Por ora saliento que, à parte a citada polêmica, o ensaio de Jakobson se consagra como um estudo notável pela argúcia e profundidade de muitas de suas observações e que, além disso, põe em relevo a alta qualidade "estrutural" dos poemas de Fernando Pessoa e a sua necessária inclusão “... entre os grandes poetas da 'estruturação',.,22

\footnotetext{
${ }^{20}$ SEABRA, 1974. p.41-42.

${ }^{21}$ Vide NUNES, 1969. p.238.

${ }^{22}$ JAKOBSON, 1978. p.121.
} 
"Pessoa revisitado: leitura estruturante do drama em gente" (1973), de Eduardo Lourenço, é outro livro de destaque dentre os que buscam compreender as razões intrínsecas da multiplicação textual em Fernando Pessoa.

Tratando-se de uma obra sobejamente conhecida e já bastante discutida por críticos de diversas orientações, não me alongo a seu respeito. Restrinjo-me a ressaltar o caráter instigante de sua revisitação do universo poético pessoano, em particular a sua sensibilidade em tentar elucidar os fundamentos da multiplicação textual heteronímica, sem apelar para expedientes "desmistificantes" e redutores, ou tentar algum tipo de conciliação. Nesse sentido, critica Lourenço as costumeiras leituras psicologistas da heteronímia, que, ao invés de analisá-la em sua qualidade literária, voltam-se para a investigação de suas supostas "origens" no psiquismo de Fernando Pessoa:

\footnotetext{
"De uma maneira ou de outra, por assim dizer, fatal, passou-se insensivelmente, do campo da análise da heteronímia ao do seu desmascaramento, já com forte coloração pejorativa e, em seguida, à desmistificação não só do jogo heteronímico como do processo poético que ele estrutura, finalmente submetido a um espécie de desmistificação. [...] Na realidade, e por diversas que sejam em profundidade, subtileza ou coerência, estas três formas de interpretação [...] têm algo em comum: todas interrogam Pessoa, todas põem ao poeta e à sua criação questôes que são mais delas que dele..."23
}

Todavia, apesar de sua desaprovação quanto às difundidas hermenêuticas do “desmascaramento", da "desmistificação", Eduardo Lourenço também recorre, nessa obra, a explicações de índole psicanalítica e psicologista, chegando mesmo a fazer uma espécie de diagnóstico psicanalítico de Fernando Pessoa. Assim sendo, sua revisitação está bem longe de ser uma releitura estritamente voltada para os aspectos literários da multiplicação heteronímica. Vale observar, entretanto, que nem por isso o autor chega a

${ }^{23}$ LOURENÇO, 1973. p.22. (Grifos do autor). 
se perder no chavão psicologista da adequação ou inadequação da poesia a uma suposta verdade interior do poeta, mantendo em primeiro plano a sua preocupação com as razões literárias da pluralidade textual em Fernando Pessoa.

José Augusto Seabra, com seu "Fernando Pessoa ou o poetodrama", é bem mais intransigente na defesa e realização da análise imanente: as explicações baseadas em fatores extrínsecos, pondera ele, são insatisfatórias, insuficientes, pois, mesmo oferecendo, aqui e ali, dados significativos para a compreensão do fenômeno investigado, o fato é que permanecem “... quase sempre na fronteira do fenômeno poético". ${ }^{24}$

Ao definir sua proposta analítica, José Augusto Seabra critica o já citado livro de Jacinto do Prado Coelho, nele apontando duas falhas primordiais: 1) uma fundamentação insuficiente, unilateral, baseada “... na simples constatação da coincidência de certos elementos e figuras retóricas, independentemente da sua articulação sintagmática nos poemas e da sua função na diversidade de atitudes poéticas de cada heterônimo",25; 2) o entendimento equivocado da “... unidade temática como unidade de 'estilo'.,26

Entende Seabra que esse enfoque unilateral acarretaria uma redução das diferenças entre os heterônimos às suas visões de mundo, explícitas ou implícitas, passando, assim, “... tangencialmente, senão ao lado do verdadeiro problema poético de

\footnotetext{
${ }^{24}$ SEABRA, 1974. p.XIV.

${ }^{25}$ SEABRA, 1974. p.XVIIn.

${ }^{26}$ SEABRA, 1974. p.XXn.
} 
Pessoa, transferindo-o para o plano da razão reflexiva, que não constitui senão uma matéria de que se nutre, entre outras, a sua poesia." ${ }^{, 27}$. Note-se, de passagem, que a crítica de Seabra à tese de Jacinto do Prado Coelho não implica uma adesão à tese oposta, da autoria de Cleonice Berardineli, segundo a qual as linguagens poéticas ortônimas e heterônimas seriam vestimentas diversas de uma mesma temática. Esta tese é também recusada por ele. ${ }^{28}$

Sintetizando, a proposta de Seabra, neste livro acima citado, é analisar a heteronímia “... em função da estrutura da obra poética em si mesma"29, ou seja, em função do jogo de oposições que se realiza de modo intensivo na linguagem poética de Fernando Pessoa: nos diálogos que se desenvolvem internamente às linguagens poéticas e às linguagens críticas, e que são fruto da leitura constante que os heterônimos fazem de si mesmos e dos outros, “... cada elemento se responde e se corresponde, num tecer e destecer sempre retomado de fios que se vão entrecruzando, em planos diversos mas que se interpenetram. ${ }^{, 30}$ Por esta razão, faz-se necessária uma abordagem que contemple a indivisibilidade dos dois aspectos, que integre a análise temática na análise das linguagens poéticas, quer ao nível da estrutura global da obra pessoana, quer no da estrutura específica de cada heterônimo, colhendo, assim, em toda a sua plenitude, o conjunto poetodramático de Fernando Pessoa, sem comprometimento do seu caráter essencialmente dialógico. ${ }^{31}$

\footnotetext{
${ }^{27}$ SEABRA, 1974. p.XVII.

${ }^{28}$ SEABRA, 1974. p.XVIIn.

${ }^{29}$ SEABRA, 1974. p.XIV.

${ }^{30}$ SEABRA, 1974. p.15-6.

${ }^{31}$ SEABRA, 1974. p.XVIII.
} 
Mas, também a abordagem desenvolvida nesse livro que acaba de ser citado recebe críticas. Segundo Fernando Segolin, em "Fernando Pessoa: poesia, transgressão, utopia" (1992), a leitura realizada por Seabra incorreria nas seguintes omissões: 1) não chegar a considerar “... o caráter marcadamente experimental e transgressor da criação poética em Pessoa ...” e “... o movimento lúdico-dialógico traçado pelos textos heteronímicos em inter-relação",32; 2) não conseguir “... determinar com clareza o papel cambiante que a palavra e o texto de Pessoa procuram assumir diante do real, no afã de exorcizar a incapacidade representativa da linguagem., ${ }^{, 33}$

A partir da crítica a essas supostas omissões, Segolin propõe-se a colocar em primeiro plano o cunho transgressor e dialógico da linguagem poética pessoana, o seu "... esforço deslocador e, por vezes, contestador de uma tradição"34, sanando, assim, as duas omissões que ele vê na análise realizada por Seabra. Procede então a um rigoroso exame do texto poético pessoano, empenhando-se em colher “... as razões que o próprio texto em si mesmo inscreve para justificar sua maneira específica de ser texto" $" 35$. Segundo suas próprias palavras, trata-se de “... retraçar, metalingüisticamente, a coreografia dialógica inscrita no texto pessoano" ${ }^{, 36}$, procedimento este que tem por fim colher, na linguagem de cada heterônimo, a encarnação e realização de uma verdadeira "revolução poética".

\footnotetext{
${ }^{32}$ SEGOLIN, 1992. p.23.

${ }^{33}$ SEGOLIN, 1992. p.23.

${ }^{34}$ SEGOLIN, 1992. p.25.

${ }^{35}$ SEGOLIN, 1992. p.22.

${ }^{36}$ SEGOLIN, 1992. p.24.
} 
Da autoria de Maria Helena Nery Garcez, existem dois ensaios — "Alberto Caeiro: 'Descobridor da Natureza'?" (1985) e "O tabuleiro antigo" (1990). Registro-os por duas razões: primeiro, por oferecerem uma instigante reflexão sobre o discurso poético dos heterônimos Alberto Caeiro e Ricardo Reis; segundo, por seu já assinalado pioneirismo na leitura de Fernando Pessoa à luz da teoria estética de Luigi Pareyson.

Em “Alberto Caeiro: 'descobridor da natureza'?”, a autora perscruta o discurso poético do heterônimo Mestre, buscando colher, em meio ao seu alcance “... contestador da linguagem mística cristã e da subjacente visão de mundo que nela se consubstancia", o seu intensivo diálogo "... com uma das obras líricas máximas da mística ocidental, 'O Cântico do Sol' de São Francisco de Assis.",37

Em "O tabuleiro antigo", o foco de interesse da autora é o texto poético de Ricardo Reis. As odes desse heterônimo neoclássico, com especial destaque para a que consta na edição Nova Aguilar com o número (337) e que fala dos jogadores de xadrez, são analisadas segundo a categoria do jogo, entendido, naturalmente, não como simples espaço lúdico e hedonista, mas como lugar de uma experiência simbólica da luta entre os princípios antagônicos fundamentais das relações humanas e, ao mesmo tempo, da dimensão transcendente que a todos supera.

Nos dois estudos, o embasamento estético em conceitos pareysonianos axiais — como os de forma (como organicidade completa, autônoma e indivisível, cujo significado primeiro remete a seu próprio corpo sensível) e o de modo de formar (como depositário do verdadeiro conteúdo poético) — permite a Maria Helena Nery Garcez

\footnotetext{
${ }^{37}$ GARCEZ, 1985. p.9-16.
} 
desvelar sentidos contidos no próprio rosto físico da poesia pessoana, ou melhor, desvelar o seu próprio rosto físico como significado, "conteúdo expresso", coincidência perfeita de fisicidade e espiritualidade, de forma e conteúdo.

De publicação mais recente, o livro "O poema e as máscaras" (1999), da autoria de Carlos Felipe Moisés, parte de um premissa básica: "O âmago da cosmovisão pessoana é constituído [...] pelo esforço no sentido de conhecer a realidade como um absoluto possível, para além das contingências" ${ }^{\text {38 }}$.

O fio condutor deste analista é a idéia de que a heteronímia não é um sistema fechado sobre si mesmo, composto por uma pluralidade finita de sujeitos poéticos, mas “... um processo, um dinamismo incessante feito de circunvoluções concêntricas e espiraladas" ${ }^{39}$, as quais se sintetizariam na estrutura composicional de "Tabacaria", de Álvaro de Campos. Devido à sistemática alternância de oposições que nele se verifica, o mencionado poema simbolizaria o processo dialético sistemático que constitui a "plataforma epistemológica" da poesia pessoana, representando assim, ao mesmo tempo, uma "síntese" e “... um centro receptor e irradiador das linhas de força que percorrem a obra de Pessoa" ${ }^{40}$. Mais à frente, no Capítulo 6, teço comentários sobre as premissas hegelianas dessa leitura.

\footnotetext{
${ }^{38}$ MOISÉS, C. F. 1998. p.56.

39 MOISÉS, C. F. 1999. p.177. (Observe-se que a "espiral" é uma conhecida metáfora do movimento progressivo subentendido pela dialética hegeliana).

${ }^{40}$ MOISÉS, C. F. 1999. p.19.
} 


\section{FUNDAMENTOS}

\subsection{Considerações iniciais}

Investigar a atitude cética na poesia de Fernando Pessoa é uma empresa complexa, cujos fundamentos adentram contextos teóricos diversos, desde os pertencentes ao campo da teoria literária, da estética e da filosofia da arte, até o das doutrinas filosóficas.

No campo da teoria da literatura, os pressupostos de minha tese se inspiram de modo marcante nas noções bakhtinianas de polifonia e intertextualidade. Por serem noções já bastante familiares no meio literário, não faço um comentário mais profundo sobre as mesmas. Destaco apenas os pontos que me despertaram para certas possibilidades interpretativas da poética de Fernando Pessoa e estimularam minha reflexão sobre as sintonias apresentadas entre a natureza e função das personagens dentro do contexto romanesco dostoievskiano e a natureza e função dos heterônimos dentro do contexto poético pessoano.

Como se sabe, o conceito de "romance polifônico" é teorizado por Mikhail Bakhtin (1895-1975). Na base de sua teorização, está uma contrastação dos romances de Dostoiévski com o romance tradicional, "homofônico", "monológico", cujas personagens e episódios compõem um mundo unificado, objetivo, dominado pelo artifício de uma narração uniforme. Dostoiévski é assim destacado como criador de “... um gênero romanesco essencialmente novo", caracterizado pela presença de vozes diversas, autô- 
nomas, eqüipolentes, dialogantes, interativas, que não se deixam fundir pela perspectiva do autor. O enraizamento social desse modo de estruturação característico do "romance polifônico" é referido, pelo teórico russo, à concepção novecentista de mundo, em especial, à crescente percepção da ambiguidade de cada voz, gesto ou ato, e à convicção de que a natureza dialógica da nossa consciência não pode ser captada através de uma linguagem discursiva e monodirecional. É, pois, em consonância com essa "Weltanschauung" que as visões conflitantes expressas pelas personagens e pelo narrador dos romances dostoievskianos coexistem, sem se deixarem unificar por um ponto de vista determinado, por uma palavra final. ${ }^{1}$

Transcrevo abaixo, algumas passagens bakhtinianas que, resguardando-se as diferenças contextuais, mostraram-se especialmente instigantes para minha reflexão sobre o universo poético de Fernando Pessoa:

\begin{abstract}
"A multiplicidade de vozes e consciências independentes e imiscíveis e a autêntica polifonia de vozes plenivalentes constituem, de fato, a peculiaridade fundamental dos romances de Dostoiévski. Não é a multiplicidade de caracteres e destinos que, em um mundo objetivo uno, à luz da consciência una do autor, se desenvolve nos seus romances; é precisamente a multiplicidade de consciências eqüipolentes e seus mundos que aqui se combinam numa unidade de acontecimento, mantendo a sua imiscibilidade. Dentro do plano artístico de Dostoiévski, suas personagens principais são, em realidade, não apenas objetos do discurso do autor mas os próprios sujeitos desse discurso diretamente significante. Por esse motivo, o discurso do herói não se esgota, em hipótese alguma, nas características habituais e funções do enredo e da pragmática, assim como não se constitui na expressão da posição propriamente ideológica do autor (como em Byron, por exemplo). A consciência do herói é dada como a outra, a consciência do outro mas ao mesmo tempo não se objetifica, não se fecha, não se torna mero objeto da consciência do autor. Neste
\end{abstract}

\footnotetext{
${ }^{1}$ Bakhtin desenvolve uma minuciosa teorização sobre a tese de que, mesmo tendo em vista que essa pluridiscursividade é “... sempre personificada, encarnada em figuras individuais de pessoas com discordâncias e contradições individualizadas”, essas contradições particulares “... encontram-se imersas na pluridiscursividade social e são reinterpretadas por ela”. A própria língua, em cada momento da sua existência histórica, é inteiramente pluridiscursiva, “... é coexistência encarnada de contradições ideológico-sociais entre o presente e o passado, entre as várias épocas do passado, entre os vários grupos ideológico-sociais do presente, entre as correntes, as escolas, os círculos etc." (BAKHTIN apud REIS; LOPES, 1987. p.325).
} 
sentido, a imagem do herói em Dostoiévski não é a imagem objetivada comum do herói no romance tradicional."2

"Suas obras marcaram o surgimento de um herói cuja voz se estrutura do mesmo modo como se estrutura a voz do próprio autor no romance comum. A voz do herói sobre si mesmo e o mundo é tão plena como a palavra comum do autor; não está subordinada à imagem objetificada do herói como uma de suas características mas tampouco serve de intérprete da voz do autor. Ela possui independência excepcional na estrutura da obra do autor. Ela possui independência excepcional na estrutura da obra, é como se soasse ao lado da palavra do autor, coadunando-se de modo especial com ela e com as vozes plenivalentes de outros heróis."3

“À semelhança do Prometeu de Goethe, Dostoiévski não cria escravos mudos (como Zeus) mas pessoas livres, capazes de colocar-se lado a lado com seu criador, de discordar dele e até rebelar-se contra ele."4

"Do ponto de vista de uma visão monológica coerente e da concepção do mundo representado e do cânon monológico da construção do romance, o mundo de Dostoiévski pode afigurar-se um caos e a construção dos seus romances algum conglomerado de matérias estranhas e princípios incompatíveis de formalização. Só à luz da meta artística central de Dostoiévski por nós formulada podem tornar-se compreensíveis a profunda organicidade, a coerência e a integridade de sua poética." ${ }^{5}$

“... o universo de Dostoiévski é, a seu modo, tão acabado e complexo quanto o de Dante. Mas é inútil procurar nele um acabamento filosófico sistêmicomonológico, ainda que dialético, e não porque o autor não o tenha conseguido mas porque ele não fazia parte dos seus planos."

"A personagem interessa a Dostoiévski enquanto ponto de vista específico sobre o mundo e sobre si mesma, enquanto posição racional e valorativa do homem em relação a si mesmo e à realidade circundante. Para Dostoiévski não importa o que a sua personagem é no mundo mas, acima de tudo, o que o mundo é para a personagem e o que ela é para si mesma."7

"Se não estiver cortado o cordão umbelical que une a personagem ao seu criador, então não estaremos diante de uma obra de arte mas de um documento pessoal." 8

${ }^{2}$ BAKHTIN, 1997. p.4-5. (Grifos do autor).

${ }^{3}$ BAKHTIN, 1997. p.5.

${ }^{4}$ BAKHTIN, 1997. p.4.

${ }^{5}$ BAKHTIN, 1997. p.6.

${ }^{6}$ BAKHTIN, 1997. p.31. (Grifos do autor).

${ }^{7}$ BAKHTIN, 1997. p.46. (Grifos do autor).

${ }^{8}$ BAKHTIN, 1997. p.51. 


\begin{abstract}
"Aqui é oportuno enfatizar mais uma vez o caráter positivamente ativo da nova posição do autor no romance polifônico. Seria absurdo pensar que nos romances de Dostoiévski a consciência do autor não estivesse absolutamente expressa. A consciência do criador do romance polifônico está constantemente presente em todo esse romance, onde é ativa ao extremo. Mas a função dessa consciência e a forma de seu caráter ativo são diferentes daquelas do romance monológico: a consciência do autor não transforma as consciências dos outros (ou seja, as consciências dos heróis) em objetos nem faz destas definições acabadas à revelia. Ela sente ao seu lado e diante de si as consciências eqüipolentes dos outros, tão infinitas e inconclusas quanto ela mesma. Ela reflete e recria não um mundo de objetos mas precisamente essas consciências dos outros com os seus mundos, recriando-as na sua autêntica inconclusibilidade (pois a essência delas reside precisamente na sua inconclusibilidade)."
\end{abstract}

Quanto à intertextualidade, interessa-me mais de perto o seu intencional acento na obra poética de Fernando Pessoa, quer dizer, o fato de que a absorção e transformação de outros textos dentro do texto poético aí se apresenta não como um simples aspecto constitutivo, natural, do discurso, mas como um procedimento explícito, intencional, que desempenha um papel determinante, tanto no sentido de questionamento da preeminência do significado autoral, quanto na criação de um espaço multidimensional, marcado pela ambigüidade, pela plurivocidade, e, por conseguinte, pela extrema dilatação das suas possibilidades interpretativas.

\title{
2.2 As relações entre poesia e filosofia
}

Ao longo da história do pensamento ocidental, o interesse da filosofia pela poesia sempre se mostrou significativo.

Remontando à Grécia do século VI a. C., época em que o pensamento se mostrava ainda oscilante entre o reinado do mito e o rigor filosófico nascente, é digno de registro que um Parmênides, por exemplo, intransigente defensor do raciocínio abs-

\footnotetext{
${ }^{9}$ BAKHTIN, 1997. p.68. (Grifos do autor).
} 
trato como forma de corrigir os erros da experiência sensível, apresente suas teses filosóficas em forma de poema, valendo-se, inclusive, de ricas metáforas.

Essa atmosfera de íntima proximidade modifica-se, contudo, com o correr do tempo, quando a postura racionalista começa a conquistar a sua hegemonia sobre o pensamento mítico.

No século V a. C., Górgias e Sócrates iniciam uma discussão que se prolongará pelos séculos afora e que tem como centro o alcance cognoscitivo da mimesis artística: para o primeiro, um recurso destinado a iludir, seduzir a imaginação; para o segundo, uma prática cujo escopo é produzir modelos idealizados, representativos da beleza ideal.

Pouco mais tarde, Platão (427-347 a. C.) e Aristóteles (384-322 a. C), assim se posicionam frente à questão:

Platão, de um lado, concede à poesia uma posição privilegiada, enquanto arte dotada de maior afinidade com a inteligência e mais próxima da contemplação das essências verdadeiras, condenando a pintura e a escultura por se esgotarem na mimesis das coisas sensíveis (as quais já são, de per si, meras aparências, fugazes e ilusórias). Contudo, embora possa ser veículo de conhecimentos privilegiados, inacessíveis à maioria dos homens, a poesia não conhece verdadeiramente a Beleza, apenas a imita, sob a inspiração das Musas, podendo enredar a alma dos jovens na trama dos falsos sentimentos, desviando-a da sua destinação suprema, que é a episteme, o conhecimento 
da verdade e do ser originário. ${ }^{10}$ É que os poetas não se guiam nem pela razão discursiva, nem pela intuitiva, mas pelo arrebatamento, pela inspiração que lhes concedem os deuses:

Aristóteles, do outro lado, sublinha o sentido mais elevado da mimesis artística. A arte é poiesis, atividade formadora, criação da qual resulta uma realidade nova, um ser. As representações miméticas por ela praticadas vão além da simples representação do efetivamente acontecido e representam o essencial do destino humano: aperfeiçoam as formas naturais, produzem modelos idealizados, enfim, representam "possibilidades humanas", elevando-se, assim, a um maior grau de universalidade. Em suma, a poesia é "mais filosófica" que a história, a qual se limita apenas a representar os fatos, tais como aconteceram. ${ }^{11}$

Para Plotino (204-270 d. C.), figura mais importante do Neoplatonismo, a beleza sensível é a alma das coisas, é a manifestação do Absoluto na matéria. Tudo que tem forma é belo. Todavia, a verdadeira beleza só se revela na alma, sendo apreensível unicamente pela visão interior.

Ressalte-se que Plotino concede à arte uma importância metafísica e espiritual sem precedentes na história do pensamento filosófico. Contra Platão, propugna ele que a arte é feita de matéria, mas representa o imaterial: seu significado é interior e inteligível. Como bem vira Aristóteles, sendo poiesis, ela é produção da qual resulta um ser, um significado novo, que transforma e enobrece a natureza. Assim, a experiência da

\footnotetext{
${ }^{10}$ A posição de Platão não é unívoca, ao longo de sua obra: em "República", expulsa o poeta, o mimetes, por ser autor de discursos mentirosos. No "Ion", entretanto, exalta-o como "coisa leve, santa e alada", cuja alma se eleva pelo delírio (entendido como uma categoria religiosa) à região da verdade suprema.

${ }^{11}$ Cf. Poética, 1451 b 5.
} 
produção artística do belo não se esgota na mimesis do sensível, mas é, antes, um grau de iniciação à intuição das Idéias ou Essências, uma forma de contemplação do Absoluto.

Note-se, entretanto, que, conquanto se pese a profunda influência de Plotino sobre os primeiros pensadores cristãos, estes não compartilham de seu reconhecimento da arte como veículo privilegiado para o conhecimento intuitivo do ser e contemplação da realidade absoluta. Tanto para Agostinho (354-430), quanto para Tomás de Aquino (1225-1274), permanece uma significativa separação entre a esfera contemplativa, a que o Belo pertence, e a esfera operativa, à qual pertence a arte. ${ }^{12}$ De certo, é digno de registro a tentativa de Tomaz de Aquino de introduzir uma definição mais fenomênica do belo, preocupando-se em estabelecer as condições que este deve atender. Mas, como assinala Benedito Nunes, "Quanto à arte, o grande teólogo medieval, que aceita a conceituação genérica de Aristóteles, considera o fazer artístico um hábito operativo, que garante a boa execução das obras, mas que não está diretamente relacionado com a Beleza."13 A união teórica de arte e beleza só ocorrerá na filosofia da Renascença, verificando-se o declínio da importância teológica e filosófica da beleza e a elevação

\footnotetext{
${ }^{12}$ Agostinho vê a beleza sensível como sedutora, vã, perecível, capaz de acorrentar a alma, afastá-la da verdade. A arte é coisa mundana, vinculada à matéria e aos sentidos, estranha à introspecção religiosa $\mathrm{e}$ ao verdadeiro conhecimento. A verdadeira beleza pertence apenas a Deus e está além da esfera sensível, só podendo ser apreendida pela intuição intelectual ou mística. Nos séculos subsequentes, tem-se: Dionísio Areopagita, séc. V ("Deus é luz" e a beleza sensível é o brilho da verdade de Deus nas coisas); Scotus Erígena, séc. IX (beleza sensível é metáfora da revelação eterna); Hugo de São Vitor, séc. XII (os sentidos nos abrem para a beleza sensível, apenas para que nelas descubramos o belo inteligível, que é reflexo de deus. A beleza sensível nos instrui de maneira simbólica, figurativa, para que captemos a verdadeira beleza, que é invisível). Note-se que o Belo é estudado por Tomás de Aquino na mesma parte da Suma Teológica que trata da existência e da natureza de Deus. A Beleza é vista como uma propriedade transcendental do Ser, paralela à Verdade e ao Bem.
}

${ }^{13}$ NUNES, 1991. p.32. 
das belas-artes a uma função espiritual mais elevada: unir a prática formativa à essência contemplativa do Belo.

No século XVII, estendendo-se o racionalismo de Descartes (1596-1650) a todos os campos, inclusive à reflexão estética, impõem-se às artes procedimentos análogos aos da ciência: leis disciplinadoras para a imaginação, fundamentação racional também para o belo e para o fazer artístico, adequação à razão e comprovação segundo suas regras.

De certo, ocorreram investidas anti-racionalistas diversas, tanto na França, quanto na Itália e na Inglaterra, tentando libertar a sensibilidade estética dessa intervenção arbitrária da razão. Algumas vezes, por exemplo, nas "Reflexões críticas sobre a poesia e a pintura" (1719), escritas pelo Abade Dubos, decaiu-se, mesmo, para uma tese sentimentalista, que avaliava a arte pela mera intensidade do sentimento provocado. $\mathrm{Na}$ estética inglesa, insistiram Shaftesbury (1671-1713), Addison (1672-1719), Hutcheson (1694-1746), cada qual a seu modo, em que o belo não pode ser captado pela faculdade de conhecimento intelectual, só podendo ser apreendido intuitivamente, por uma espécie de visão interior ou entendimento intuitivo, uma faculdade inata, que permite ao homem deleitar-se com o reconhecimento do belo. Esse deleite, que é o efeito essencial do belo, é um prazer de natureza espiritual, resultante da intuição do belo na experiência sensível, plenamente satisfatório e auto-suficiente. Tudo o que produz esse prazer específico é belo. Beleza é a Verdade apreendida pela intuição. Daí, a idéia de que pela experiência estética, o homem chega à mais pura harmonia com o mundo: não compreende racionalmente, mas experimenta intuitivamente a união do mundo exterior com o interior, a íntima conexão de sentido do universo. 
Ainda na transição do século XVII para o XVIII, Giambattista Vico (16681744) se destaca, no domínio da filosofia italiana, por sua posição claramente anticartesiana: à razão, colocada por Descartes como órgão da verdade demonstrativa, contrapõe ele a fantasia poética — o engenho — ou seja, a faculdade de inventar, de descobrir o verossímil e o novo. As faculdades da mente são indivisíveis e se constituem como uma só operação - a percepção — de modo que não existe figurar e inventar que não seja conhecer, nem conhecer que não seja já figurar e inventar. ${ }^{14}$ Imitação e invenção não se excluem, antes se implicam. O próprio imitar é já um inventar, pois é obra de engenho. Eis porque a poesia, mesmo sendo imitação, é, ao mesmo tempo, criação.

Em meados do século XVIII, destaca-se um confronto significativo e de consequiências decisivas para o pensamento estético subseqüente: de um lado Alexander Baumgarten (1714-1762) situa a beleza e seu reflexo nas artes como formas de conhecimento confuso e inferior ao conhecimento racional, este sim, dotado de clareza e tendente à verdade; do outro, contrapõe Immanuel Kant (1724-1804) que a experiência da beleza não é de caráter cognoscitivo: a beleza é objeto de uma experiência diferenciada, desinteressada, de caráter contemplativo, totalmente desvinculada de fim objetivo e

\footnotetext{
${ }^{14}$ É o nexo indissolúvel de figuração fantástica, reação sentimental e conhecimento sensível que caracteriza a 'percepção'. A fantasia é memória, isto é, figura e traduz em imagem a reação sentimental que acompanha necessariamente o conhecimento sensível, o que significa que as imagens do conhecimento sensível são já, de per si, a figuração daquela reação sentimental que necessariamente acompanha a sensação. Essa atividade inventiva prolonga-se, sem solução de continuidade, na atividade técnica, revelando-se como aquele fazer inerente ao conhecimento e que se prolonga no fazer que existe na raiz das artes. Assim como a fantasia é alimentada pelos sentidos através da memória, do mesmo modo o engenho é alimentado pela fantasia. A fantasia é memória enquanto é ligada ao sentido, é engenho enquanto conecta e ordena as suas figurações. A inventividade do engenho é de natureza fantástica, assim como a figuratividade da fantasia é de natureza sensível e passional.
} 
desembaraçada dos conceitos do entendimento, daí resultando que o juízo a ela correspondente não pertence à classe dos juízos de conhecimento. ${ }^{15}$

Com Schiller (1759-1805), poeta, filósofo e ativo integrante do Sturm und Drang, enriquece-se a estética do romantismo com uma idéia básica: o estado estético é um estado em que a mente se torna extremamente receptiva, libertando-se de qualquer determinação, sensível ou racional, ou seja, é um estado de mera determinabilidade da mente, em que o racional e o sensível estão equilibrados, neutralizam-se tanto o rigor das formas abstratas, produzidas pela razão, quanto a imediatidade das sensações passageiras. Trata-se, pois, do estado mais propício, tanto para a produção e apreensão do belo, quanto para o conhecimento e para o exercício da moralidade. A arte resulta do estado estético, caracterizando-se como um processo de espiritualização das coisas, nela se revelando a plenitude dos sentimentos e intenções valorativas do artista, diante de si mesmo e do mundo. Entretanto, a beleza pura, o efeito estético puro, são apenas uma meta ideal, que nunca se realiza completamente na experiência concreta. Em virtude da natureza mista do homem, sempre prevalece um dos aspetos fundamentais que o constituem (sensível ou racional), impossibilitando assim o equilíbrio perfeito.

No Idealismo alemão, a arte se consagra como objeto de uma experiência cognoscitiva privilegiada. Schelling (1775-1854), sobretudo, a eleva à função de órgão do saber transcendental e superior — a arte é o órgão supremo da filosofia, o seu representante qualificado, capaz de suprir as limitações do conhecimento racional e alcançar a intuição do Absoluto. A arte, unicamente, pode reconstituir o Absoluto, pondo a inte-

\footnotetext{
15 Segundo Kant, o sentimento do belo nasce da estrutura interna do espírito humano e se projeta nos objetos exteriores, independentemente do conteúdo empírico da representação e da contingência da experiência individual do contemplante.
} 
ligência humana em imediato contato com a Beleza, que é a revelação do infinito no finito e, portanto, equivalente à Verdade. Essa unidade entre Beleza e Verdade, determinando um estreito parentesco entre poesia e filosofia, é confirmado em "Bruno" (1802), com base no argumento da unidade indissolúvel de seu conteúdo: a beleza imortal e a verdade eterna. Contudo, há uma distinção básica: enquanto a filosofia conhece os arquétipos eternos (a verdade e a beleza em si), de modo direto e interior (na pura interioridade da especulação), a poesia visa as idéias refletidas nas coisas (a poesia não representa a beleza em si, mas somente as coisas belas).

Em Hegel (1770-1831), entretanto, resulta ambíguo o sentido dessa elevação da arte à função de órgão do saber transcendental e superior. Por um lado, a arte é situada na esfera do Espírito absoluto, compartilhando, juntamente com a religião e a filosofia, o mesmo conteúdo privilegiado: a Idéia, a verdade total, união do subjetivo com o objetivo. Por outro lado, devido à contradição interna que carrega em si, ou seja, ao fato de ser composta de matéria e espírito, a arte se encaminha para uma inexorável superação por formas inteiramente espirituais, como a religião e, finalmente, a filosofia, única capaz de elevar a Idéia ao estado de objeto para o puro pensamento racional.

Como se pode notar, por esse panorama filosófico até aqui delineado, evidencia-se, em maior ou menor medida, uma subordinação da reflexão aos princípios e postulados do racionalismo metafísico, o que, naturalmente, dificulta uma adequada avaliação das relações entre poesia e filosofia. Na verdade, embora seja correta a observação de que “... de Platão a Kant, passando pelos escolásticos, e de Kant a Hegel, passando por Schelling e Schopenhauer, os filósofos nunca deixaram de ouvir e apreciar 
o canto das Musas"16 , é forçoso acrescentar que esse "canto das Musas", embora ouvido e apreciado, foi sempre olhado com muita desconfiança pelo racionalismo filosófico predominante, quando não depreciado em seu valor veritativo e em seu alcance ontológico.

Só de meados do século XIX em diante, com o declínio dessa poderosa vertente filosófica e início da chamada "crise da razão", é que, de fato, se abre espaço para a reconciliação entre poesia e filosofia.

Cabe a Martin Heidegger o papel central nessa reviravolta, que vai culminar em meados do século XX, não apenas com o reconhecimento da poesia como sendo da mesma ordem que a filosofia e o pensar filosófico (situando-se ambas no cerne da questão fundamental do ser e da verdade), mas com um adequado entendimento da ontologicidade da arte, quer dizer, de que a obra não é apenas documento ou signo de um mundo acabado, já constituído, mas, antes de tudo, uma origem, no sentido de que institui e funda um mundo. Essa dimensão inequivocamente ontológica que Heidegger outorga à poesia altera decisivamente os limites em que sempre foi pensada esta questão. Todavia, vale registrar a advertência do filósofo de "Ser e Tempo": a criação poética e o pensar não são idênticos; de fato, são como duas montanhas bem próximas uma da outra e que se destacam numa planície, situando-se, no alto de seus respectivos cumes, o poeta e o filósofo, ambos a olhar para o ser.

Em meados do século XX, mais precisamente em 1954, Luigi Pareyson (1918-1991) publica sua "Estetica; teoria della formatività". Detalharei, mais adiante, os conceitos centrais dessa estética, ressaltando, por ora, apenas o seu inestimável contri-

\footnotetext{
${ }^{16}$ NUNES, 1993. p.83.
} 
buto para o reconhecimento da arte como um fato ao mesmo tempo ontológico e hermenêutico — ontológico, não só porque é criação pessoal, e, como a pessoa, está em relação com o ser, mas também porque a transformação da matéria e dos conteúdos espirituais que nela tem lugar institui e funda um sentido novo, uma nova realidade, um novo ser; hermenêutico, no sentido de que seus produtos resultam de uma interpretação da realidade e vivem doravante através dos infinitos atos interpretativos a que se oferecem.

No que toca mais diretamente às relações entre poesia e filosofia, entende Pareyson que são, de fato, operações distintas, mas unificadas pelo exercício de atividades comuns: assim como o êxito filosófico requer um exercício formativo, também o êxito poético requer um exercício especulativo, sendo tudo isto garantido pela própria indivisibilidade da mente humana, sempre inteiramente presente em cada operação. ${ }^{17}$ Em sentido amplo, diz ele, esta é uma questão que se põe para todas as artes, mas, de modo mais específico e complexo, “... per quelle della scrittura, dove la materia dell'arte è la parola, presa nel suo duplice carattere di suono e di senso, e quindi mossa dall'esigenza d'esser considerata di per sé e insieme dotata della capacità di manifestare il discorso del pensiero." 18

\footnotetext{
${ }^{17}$ Como se verá adiante, se isto acontece, é porque, fundando-se o operar humano na mútua implicação de todas as funções espirituais, o fazer poético confere uma singular evidência ao exercício formativo que o especifica e, ao mesmo tempo, sustenta-o com o exercício de pensamento constitutivo da própria filosofia, sem qualquer comprometimento do êxito artístico.

18 PAREYSON, 1991. p.300. T. da A.: “... para as da escrita, onde matéria da arte é a palavra, tomada no seu duplo caráter de som e sentido, portanto impelida pela exigência de ser considerada por si mesma e, simultaneamente, como capaz de manifestar o discurso do pensamento."
} 
Destaco algumas ponderações pareysonianas sobre a "distinção/unidade" de poesia e filosofia: primeiramente, o fato de que, em seu caraterístico movimento de busca e discussão da verdade, a filosofia possui aspectos que, se adequadamente acentuados, podem transformá-la em genuína poesia, sem que haja comprometimento dos dois campos. Nos escritos de Giordano Bruno, para citar apenas um dos exemplos dados por Pareyson, a filosofia se enlaça a tal ponto com a exuberância estilística que a apreciação do valor especulativo não pode passar ao largo de seu êxito poético, ou seja,

“... l'esito artistico non è qualcosa di aggiunto, come se si trattasse di dare, per motivi retorici, una 'forma' artistica a una 'materia' che potrebbe esser esposta in altro modo: quella 'forma' è essenziale allo stesso esercizio del pensiero, e vi acquista un valore speculativo, perché lí il pensiero non sarebbe quello che è come pensiero se non fosse, insieme, arte."19

Por outro lado, existe uma indefectível presença filosófica na arte. E, ao contrário do que pensam alguns, isso não acontece apenas quando a filosofia se concretiza em imagens, figuras sensíveis. A filosofia é compatível com a poesia também quando se apresenta em seu rigor especulativo caraterístico, em sua formulação mais técnica e precisa, podendo até tornar-se realidade de poesia, quer dizer, “... ser ela própria poesia." 20

Com efeito, não são poucos os casos de obras que, justamente enquanto bem sucedidas no plano artístico, assumem função de filosofia, sem por isso deixar de ser

\footnotetext{
19 PAREYSON, 1991. p.306. T. da A.: “... o êxito artístico não é algo que vem de acréscimo, como se se tratasse de dar, por motivos retóricos, uma 'forma' artística a uma 'matéria' que poderia ser exposta de outro modo: aquela 'forma' è essencial ao próprio exercício do pensamento, e ganha ali um valor especulativo, porque o pensamento não seria aquilo que é como pensamento, se não fosse, simultaneamente, arte."

${ }^{20}$ PAREYSON, 1997.p.48.
} 
arte: é que, nelas, a própria arte é uma forma de fazer filosofia. Os exemplos são muitos e inesquecíveis. Pareyson menciona alguns:

Dante e Lucrezio, onde, “... spesso la filosofia quanto piú nudamente è esposta tanto piú si fa sublime poesia ..." ${ }^{21}$;

“...Dostoievski, i cui romanzi, proprio nella loro validità artistica, sono schietta e genuina filosofia, perché i personaggi hanno il duplice eppure unico carattere di figure d'arte e d'idee filosofiche, al punto che si può dire ch'egli filosofasse 'mediante' l'arte, o che, facendo arte, facesse in fondo filosofia",22;

“... la letteratura greca dei primi secoli, quando poema, tragedia e lirica tenevan posto di filosofia, e ne assolvevano la funzione nella loro stessa realtà d'arte". 23

Acrescentemos a esses exemplos, no contexto da língua portuguesa, o nome

de Luís de Camões, onde a própria concreção poética se torna profundidade filosófica.

Enfim, em todos esses casos, aplica-se o sábio juízo de Pareyson, segundo o qual “... si può dire che l'arte di quei grandi fosse un modo di far filosofia, il loro personalissimo modo, e che, conformemente al loro 'genio', far filosofia non potesse esser altro che creare quelle opere d'arte immortali." ${ }^{24}$

Naturalmente, isso não exclui a existência de numerosos exemplos de acabamento infeliz, os quais redundam num comprometimento tanto da filosofia quanto da

${ }^{21}$ PAREYSON, 1991. p.306. T. da A.: “... amiúde a filosofia, quanto mais nuamente exposta tanto mais se faz sublime poesia ...".

22 PAREYSON, 1991. p.307. T. da A.: “... Dostoievski, cujos romances, precisamente na sua validade artística, são pura e genuína filosofia, porque as personagens têm o duplo, embora único caráter, de figuras de arte e de idéias filosóficas, a tal ponto que se pode dizer que ele filosofava 'mediante' a arte, ou que, fazendo arte, fazia, no fundo, filosofia";

23 PAREYSON, 1991. p.307. T. da A.: “... a literatura grega dos primeiros séculos, quando poema, tragédia e lírica tinham posto de filosofia, e absorviam sua função na sua própria realidade de arte”.

24 PAREYSON, 1991. p.307-8. T. da A.: “... pode-se dizer que a arte desses grandes era um modo de fazer filosofia, o seu personalíssimo modo, e que, em conformidade com o seu 'gênio', fazer filosofia não poderia ser outra coisa senão criar aquelas obras de arte imortais." 
poesia. É o que acontece, por exemplo, num certo tipo de poesia, a chamada "poesia filosófica", que se esgota numa versificação de conceitos (como se poetar fosse revestilos de uma bela veste sensível). Nesse caso, sim, pode-se dizer que a tese destrói a poesia, acarretando o comprometimento dos dois valores, pois não basta a versificação para que o pensamento se traduza em poesia. Como recorda Fernando Pessoa, se a prosa “... vive primordialmente do sentido directo da palavra ..." e a literatura “... dos sentidos indirectos da palavra — do que a palavra contém, não do que simplesmente diz ...”, a poesia, por sua vez, “... vive primordialmente da projecção de tudo isso no ritmo ...". 25

Todavia, “... nas mãos de um grande artista, a tese torna-se arte, porque sua própria arte é uma tese. As maiores obras de todos os tempos são, no fundo, obras de tese...,"26. Nesse caso, “... oltre che splendere la verità filosofica, vibra anche l'adesione personale del poeta alla sua filosofia, ch'è presente non meno come ragion di vita che come sistema concettuale" ${ }^{27}$, verificando-se, então, um perfeito equilíbrio, uma perfeita coessencialidade, entre o rigor especulativo da filosofia e a vibração emotiva da expressão poética: em cada verso, “... la parola, rivelando la profondità del pensiero, ne canta insieme la nobiltà ed elevatezza, e la verità vi si mostra nella sua forza persuasiva, capace di signoreggiare l'animo e d'impadronirsi della mente e del cuore." 28

\footnotetext{
${ }^{25}$ PESSOA, 1973. p.81.

${ }^{26}$ PAREYSON, 1997. p.48.

${ }^{27}$ PAREYSON, 1991. p.305. T. da A.: “... além de resplandecer a verdade filosófica, vibra também a adesão pessoal do poeta à sua filosofia, que está presente não menos como razão de vida que como sistema conceitual”.

${ }^{28}$ PAREYSON, 1991. p.305. T. da A.: “... a palavra, revelando a profundidade do pensamento, canta ao mesmo tempo a sua nobreza e elevação, e a verdade aí se mostra em sua força persuasiva, capaz de dominar o ânimo e assenhorar-se da mente e do coração."
} 


\subsection{As poéticas novecentistas: alcance ontológico}

Há praticamente uma unanimidade entre os críticos e estudiosos da história da literatura em identificar, como a característica mais marcante do século XX, o direcionamento auto-reflexivo, ou seja, o voltar-se da obra para as suas próprias razões intrínsecas, para o seu próprio modo de formar. De fato, não apenas na poesia, mas na arte de modo geral, inicia-se, desde fins do século XIX, um processo de auto-reflexão crescente, centrado na convicção do papel essencialmente fundante e estruturante da linguagem, que se proclama agora como o fundamento mesmo da comunicação humana, configurando-se, além disso, como um fato histórico, comprometido com todo um conjunto de relações que nele se refletem e que ele contribui para modificar. Já com o simbolismo, entendendo-se a linguagem da poesia como expressão dos sentimentos inalcançáveis mediante uma abordagem direta e formas definidas, desenvolvera-se uma poética da sugestão, baseada no uso do símbolo como meio de comunicação do indefinido e na utilização da própria composição espacial do texto poético como meio de revelar relações secretas entre as coisas (por isso, os jogos tipográficos diversos, espaços brancos em torno das palavras, etc.). A partir daí, as poéticas nascentes desinstrumentalizam cada vez mais a palavra, tematizam-na como objeto privilegiado da comunicação e fim primeiro da leitura.

Vale observar que esse febril desdobrar-se da arte em atos sucessivos de radical renovação e contestação das linguagens precedentes não fica restrito a aspectos técnico-programáticos, mas implica uma profunda reflexão sobre o significado mesmo da operação artística, o que lhe confere um sentido intrinsecamente revolucionário: 
renovar as formas da arte implica renovar as relações humanas em seus mais diversos níveis.

Salientando o alcance ontológico dessas poéticas, observa Gianni Vattimo “... che si tratta di 'poetiche' sui generis, che sono piuttosto vere e proprie prese de posizione filosofiche sull'arte." 29 Observe-se que o filósofo se fundamenta aqui no conceito pareysoniano de modo de formar, elemento indispensável para o entendimento de que a ênfase metalinguística, longe de acarretar uma suposta debilitação ontológica da poesia, consolida o seu alcance ontológico. Em arte, o modo de formar, o estilo, é ao mesmo tempo um modo de ver as coisas e de se posicionar diante do mundo. Isto porque, como bem explica Umberto Eco, retomando Pareyson, o discurso primeiro da arte, o único dotado “... de significado real, ela o faz dispondo suas formas de uma maneira determinada, e não pronunciando, através delas, um conjunto de juízos a respeito de determinado assunto" ${ }^{30}$. Mais adiante: "O verdadeiro conteúdo da obra torna-se o seu modo de ver o mundo e de julgá-lo, traduzido em modo de formar, pois é nesse nível que deverá ser conduzido o discurso sobre as relações entre a arte e o mundo."’31

Desse ponto de vista, a preocupação auto-expressiva e auto-reflexiva das poéticas vanguardistas nascentes — tantas vezes acusadas de serem geradoras de produ-

\footnotetext{
${ }^{29}$ VATTIMO, 1985. p.36. T. da A.: “... que se trata de 'poéticas' sui generis, que são, mais frequentemente, verdadeiras tomadas de posição filosófica sobre a arte.”

${ }^{30}$ ECO, 1976. p. 255-6.

31 ECO, 1976. p.258. Cf. outros livros e ensaios, onde Eco desenvolve esses conceitos pareysonianos: A estrutura ausente; introdução à pesquisa semiológica. São Paulo: Perspectiva, 1971; Obra aberta; forma e indeterminação nas poéticas contemporâneas. São Paulo: Perspectiva, 1976; A definição da arte. São Paulo: Martins Fontes, 1981; Le sporcizie della forma. Rivista di estetica, fasc. 40-1, p.17-23, 1993.
} 
tos vazios e ornamentais, destinados a uma mera "fruição estética" — sinaliza uma tomada de consciência do alcance fundante, originário, da arte.

Contudo, por excessivo temor de recair no conteudismo (que, de certo modo, remete a Hegel e sua definição da arte como manifestação sensível do absoluto), uma certa estética, tendencialmente formalista, acaba por desconhecer o peso determinante do apelo cognoscitivo da arte e da poesia.

Mas, que implicações tem esse reconhecimento da essência fundante e inaugurante da arte para a sua leitura e interpretação?

Antes de mais nada, trata-se de tentar uma leitura que não tome a obra apenas como reflexo, documento ou expressão de uma situação já constituída e à qual ela remeteria. Quer dizer, uma leitura que tenha presente que a arte é, antes de tudo, fundação de uma linguagem e portanto de um mundo, que não corresponde a regras prefixadas, mas as institui; que não se insere simplesmente no mundo existente, mas o funda, quer dizer, é, em si mesma, “... una fondazione di realtà”, ${ }^{32}$. Trata-se, enfim, de ver que a obra “... non è solo segno di un mondo già costituito, non è una voce del passato, ma anzitutto è l'apello di un mondo che nasce com lei” ${ }^{33}$; “... un appello che non ricuiede solo una esplicitazione, ma una risposta."

\footnotetext{
32 VATTIMO, 1985. p.53. T. A.: “... uma fundação de realidade”.

33 VATTIMO, 1985. p.108. T. A..: “... não é somente signo de um mundo já constituído, não é uma voz do passado, mas antes de tudo é o apelo de um mundo que nasce com ela".

${ }^{34}$ VATTIMO, 1985. p.113. T. da A.: “... um apelo que não requer somente uma explicitação, mas uma resposta."
} 
O reconhecimento da ontologicidade da poesia, embora implícito já em "Estetica; teoria della formatività", é mais explicitamente realçado em obras posteriores de Luigi Pareyson, como no ensaio "La obra de arte y su público", publicado no final da década de oitenta. ${ }^{35}$ Nesse escrito — que discute a problemática da socialidade e historicidade da arte e a permanência da obra ao longo da história — há uma ênfase considerável no constituir-se da obra de arte, primordialmente, como uma origem, fundação de uma nova realidade:

\begin{abstract}
"El arte no le sobreviene a la realidad ya existente, sino que funda él una nueva realidad; ela arte no refleja un espírito ya formado, sino que nos enseña él una nueva forma de humanidad, el arte no expresa un mundo acabado, sino que descubre él un mundo nuevo; y ello porque el arte se instala en el próprio corazón de la realidad en movimiento y porque la obra de arte es en sí una realidad, un espíritu, un mundo: su propia realidad, su propio espírito, su propio mundo. Su poder no consiste en concluir una época; si así fuese, moriría com su época, arrastrado por ese mismo tiempo que quería detener y fijar en la expresión; su poder consiste más bien en abrir el tiempo y en comenzar una época, en el sentido de que ella es en sí un tiempo nuevo y una época nueva. El arte tiene el poder de 'comenzar' porque él es un comienzo: es 'inicial', aún mas, es - por decirlo de algún modo - 'iniciático', non solo porque es 'original', sino, más aún, porque es 'originario'."’36
\end{abstract}

Resumindo, a arte, conquanto tenha um caráter social, histórico, não se reduz a mera expressão ou reflexo de sua época, nem se deixa diluir num consumo destrutivo, antes, é reveladora e fundadora: descobre um novo mundo, abre uma nova época. E se isto acontece, finaliza Pareyson, é porque ela “... se instala en el propio corazón de

\footnotetext{
${ }^{35}$ Este ensaio não consta da edição original (1966), mas apenas da edição espanhola (1988) e da francesa (1992).

${ }^{36}$ PAREYSON, 1988. p.57-8. T. da A.: "A arte não sobrevem à realidade já existente, mas funda uma nova realidade; a arte não reflete um espírito já formado, mas nos ensina uma nova forma de humanidade, a arte não expressa um mundo acabado, mas descobre um mundo novo; e isto porque a arte se instala no próprio coração da realidade em movimento e porque a obra de arte é, em si, uma realidade, um espírito, um mundo: sua própria realidade, seu próprio espírito, seu próprio mundo. Seu poder não consiste em concluir uma época; se assim fosse, morreria com sua época, arrastada por esse mesmo tempo que queria deter e fixar na expressão; seu poder consiste mais propriamente em abrir o tempo e em começar uma época, no sentido de que esta é, em si, um tempo novo e uma época nova. A arte tem o poder de "começar' porque ela é um começo: é 'inicial', ainda mais, é - para dize-lo de algum modo - 'iniciática', não só porque é 'original', mas, mais ainda, porque é 'originária'."
} 
la primera y originaria relación entre el hombre y el ser y entre la persona y la verdad. $" 37$

Compartilhando esse ponto de vista e apresentando desenvolvimentos bastante instigantes, Gianni Vattimo põe em especial relevo o fato de que a poesia não é simplesmente uma coisa entre coisas, quer dizer, ela não simplesmente se insere entre as coisas existentes no mundo, mas

“... piuttosto lo modifica qualitativamente: non è una cosa fra le altre, ma una luce diversa gettata sulle cose. In questo senso essa ha un carattere di personalità. Non si inserische come elemento nella nostra Weltanschauung, è essa una Weltanschauung con cui si deve entrare in dialogo [...] essa fonda un mondo il quale, lungi dall'essere un puro evento della coscienza del lettore, costituisce un ambito entro cui egli stesso vive e si muove." ${ }^{38}$

\subsection{Pareyson: estética e "ontologia hermenêutica"}

A estética da formatividade ${ }^{39}$ não constitui um filão marginal da filosofia de Luigi Pareyson, antes se insere, profundamente, no horizonte reflexivo mais amplo da sua "ontologia hermenêutica".

${ }^{37}$ PAREYSON, 1988. p.58. T. A.: “... se instala no próprio coração da primeira e originária relação entre o homem e o ser, entre a pessoa e a verdade."

38 VATTIMO, 1985. p.108. N. da T.: “... antes o modifica qualitativamente: não é uma coisa entre as outras, mas uma luz lançada sobre as coisas. Nesse sentido, ela tem um caráter de personalidade. Não se insere como elemento na nossa Weltanschauung, ela é uma Weltanschauung com a qual se deve entrar em diálogo [...] ela funda um mundo, o qual, longe de ser um puro evento da consciência do leitor, constitui um âmbito dentro do qual ele próprio vive e se move."

39 A teoria da formatividade foi publicada, inicialmente, de modo fragmentado, na revista Filosofia (1950-4), recebendo uma primeira edição integral sob o título: Estetica: teoria della formatività, 1954 (2.ed.1960; 3.ed.1974; 4.ed.1988; 5.ed.1991). Este livro conta com uma edição romena (1977) e uma edição brasileira (1993). Cf. também: Teoria dell'arte. Milão: Mursia, 1965; Conversazioni di estetica. Milão: Mursia, 1966 (edição espanhola: 1985; 1988; edição francesa: 1992); e I Problemi dell'estetica. Milão: Marzorati, 1966 (em português, 1984; 1989; 1997). 
Antes de mais nada, destaca-se este filósofo no panorama da hermenêutica contemporânea pelo pioneirismo e originalidade de suas soluções. ${ }^{40}$

Dois aspectos são decisivos para seu singular encaminhamento hermenêutico: no campo do idealismo alemão, o seu partir diretamente de Fichte e Schelling, e não de Hegel; no campo da filosofia contemporânea, o seu remeter-se não apenas a Heidegger, mas também a Jaspers e Marcel (segundo ele, os únicos legítimos representantes do verdadeiro existencialismo, em direta conexão com a dissolução do horizonte unificante e sistemático do hegelianismo).

Contrário tanto ao escopo totalizante da filosofia de Hegel, quanto à genericidade do relativismo historicista, reivindica Luigi Pareyson o reconhecimento do caráter indivisivelmente histórico e ontológico da filosofia e, por conseguinte, o seu alcance veritativo. Sua proposta configura-se como uma "ontologia hermenêutica", dedicada a colher a raiz ontológica da interpretação, ou seja, o nexo que liga inseparavelmente o aspecto histórico ao ontológico, no interior do próprio ato interpretativo.

Note-se bem: trata-se não de uma filosofia do sujeito, mas de uma filosofia da pessoa, mais precisamente, de um personalismo ontológico ${ }^{41}$, de acordo com o qual, sujeito e pessoa se configuram como conceitos bem diversos. É que, sendo indivisíveis

\footnotetext{
40 Suas primeiras publicações datam de fins da década de quarenta. Portanto, antecipam de muito as de Gadamer e Ricoeur, teóricos geralmente apontados como inauguradores dessa linha de pensamento. O próprio Gadamer, em "Wahrheit und Methode" (1975), registra seu prévio conhecimento e concordância com os conceitos centrais da "teoria da formatividade", publicada (1954). (GADAMER, 1977. p.163n.28). A respeito do pioneirismo e singular posição hermenêutica de Pareyson, Cf.: VATTIMO, 1992. p.55-71; VATTIMO, 1993:3-16; RUSSO, 1993. p.15-30; SARTO, 1998. p.7-40. Registre-se que Pareyson é o introdutor da filosofia da existência na Itália, tendo publicado, nesse campo, as seguintes obras: "La filosofia dell'esistenza e Carlo Jaspers" (1940), "Studi sull'esistenzialismo" (1943), "Esistenza e persona" (1950), além de vários ensaios críticos sobre Heidegger (1938-43).

41 A teorização desse personalismo já se delineia na década de cinqüenta — especialmente em "Esistenza e persona" (1950), "Unità della filosofia" (1952) e na já citada "Estetica: teoria della formatività" (1954) — mas realiza-se do modo mais completo em "Verità e interpretazione" (1971).
} 
as faculdades da mente, o agir da pessoa é ao mesmo tempo ativo e receptivo, de modo que, no processo perceptivo, ela interioriza suas percepções, mas não as anula ou reduz a conteúdo espiritual $^{42}$. Já o agir do sujeito tende a reduzir a conteúdo espiritual todas as realidades com que entra em relação, anulando-as e privando-as de sua independência. Daí a premissa básica que norteia a filosofia de Pareyson: sujeito e objeto não são os termos da relação cognoscitiva, mas pessoa e verdade.

Dessa base filosófica, decorrem algumas conclusões axiais:

— a verdade não pode ser colhida em sentido objetivo e definitivo, pois “... non è oggetto ma origine del pensiero, non risultato ma principio della ragione, non contenuto ma fonte dei contenuti..."; ademais, ela “... non si offre se non all'interno d'un'interpretazione storica e personale ..."43;

— todavia, isto não significa que cada interpretação seja, necessariamente, parcial, incompleta; pelo contrário, cada legítima interpretação é uma "totalidade", não no sentido de que seja sempre verdadeira, mas no sentido de que contém a verdade em sua inteireza, enquanto a realiza como singular; quer dizer, a interpretação “... non è una parte della verità o una verità parziale, ma è la verità stessa come personalmente

\footnotetext{
${ }^{42}$ Pareyson desenvolve aqui uma idéia já defendida por Vico: as faculdades da mente se constituem como uma só operação - a percepção —, sendo portanto indivisíveis. Em suma: coincidência e indissolubilidade de receptividade e atividade.

${ }^{43}$ PAREYSON, 1994. p.9. T. da A.: “... não é objeto, mas origem do pensamento; não resultado, mas princípio da razão; não conteúdo, mas fonte dos conteúdos...”; “... não se oferece a não ser no interior de uma interpretação histórica e pessoal ...".
} 
posseduta, che come tale non solo non ha bisogno di integrazione, ma nemmeno la tollera, e anzi la respinge, avendo già tutto quello che può e deve avere" ${ }^{, 44}$;

— sob outro ângulo, tem-se que: por um lado, a verdade se identifica com cada legítima interpretação, mas de modo provisório (pretender que uma interpretação seja única e definitiva é pretender uma "sub-rogação da verdade" e não uma interpretação); por outro lado, a verdade situa-se sempre além de cada uma das interpretações que recebe (não no sentido de uma absoluta inefabilidade, diante da qual todas as enunciações se mostrariam fatalmente inadequadas, mas no sentido de que a verdade exige e permite uma pluralidade de interpretações, não se esgotando em nenhuma delas).

Ao contrário do que pode parecer à primeira vista, Pareyson não incorre na ingenuidade de ignorar a subsistência de um "não dito". É claro, há sempre um intervalo intransponível entre o dito e o não dito, quer dizer, a palavra sempre remete a algo de não explícito e que contém o verdadeiro significado do discurso. Mas nem sempre esse não dito é suscetível de "desmascaramento". Se no pensamento comum, ele está fora da palavra, podendo ser buscado no nível da mera expressão de seu tempo ${ }^{45}$, por outro lado, há um tipo de pensamento, de cunho "revelativo", "ontológico", no qual o não dito reside na própria palavra, não como resíduo subentendido e que possa ser objeto de uma explicitação completa, mas como "estímulo inesgotável” de revelação. Esse último tipo de discurso requer interpretação, única forma de conhecimento capaz de conter a

\footnotetext{
${ }^{44}$ PAREYSON, 1994. p.76-7. T. da A.: “... não é uma parte da verdade ou uma verdade parcialmente possuída, mas é a verdade mesma como pessoalmente possuída, que como tal não só não tem necessidade de integração, mas nem ao menos a tolera, antes a repudia, na medida em que tem tudo aquilo que pode $\mathrm{e}$ deve ter."

45 Neste caso, compreender requer que se sane essa discrepância, que se desmascare a diversidade entre o dito e o não dito, desembaraçando-se do explícito e suprimindo o subentendido como tal na evidência absoluta.
} 
verdade como inexaurível; e se nunca atinge a completa explicitação não é “... por inadequação da palavra, mas precisamente por sua capacidade de possuir um infinito...". ${ }^{46}$ Enfim, se no primeiro é preciso "desmistificar", "desmascarar", no segundo, impõe-se interpretar.

Como se vê, a questão é que Pareyson distingue um "não dito" próprio da legítima interpretação, o qual “... non è un residuo sottinteso che si possa facilmente enunciare, bensí un implicito infinito che alimenta un discorso continuo e senza fine." ${ }^{„ 47}$ A sede desse "não dito", como foi dito acima, é a própria palavra, a qual só é inadequada se entendida racionalisticamente, pelo parâmetro da explicitação total; mas, desde que devidamente entendida, revela-se como sede adequada para colher a verdade e conservá-la em sua inexauribilidade. Sua conclusão é, pois: se a verdade não pode ser explicitada de uma vez por todas, não é por serem necessariamente subjetivas, parciais, insuficientes, as formulações que dela se dão, mas por terem como objeto algo inexaurível.

Manifestação e latência apresentam-se assim como dimensões inseparáveis e inerentes à própria natureza da interpretação, daí decorrendo que qualquer dissociação entre elas desvirtua o significado hermenêutico do ato interpretativo — seja pela hipótese de uma completa explicitação, seja pela de um total ocultamento (que tem algo de nostálgico em relação ao culto racionalista do explícito, arriscando-se inclusive a não passar de uma simples inversão do mesmo).

\footnotetext{
${ }^{46}$ PAREYSON, 1994. p.115-7.

47 PAREYSON, 1994. p.77. T. da A.: “... não é um resíduo subentendido, que possa ser facilmente enunciado, mas, antes, um implícito infinito que alimenta um discurso contínuo e sem fim.”
} 
Finalizando estas considerações sobre a "ontologia hermenêutica" pareysoniana, é útil acrescentar que, nos últimos anos de vida do filósofo, ela se desenvolve em direção a uma "ontologia da liberdade", que se formula também como "pensamento trágico". ${ }^{48}$ Esse "pensamento trágico" encontra-se formulado numa série de ensaios, postumamente compilados por Giuseppe Riconda e Gianni Vattimo, e publicados sob o título "Ontologia della libertà" (1995).

Passando à "estética da formatividade", são várias as razões que me levam a toma-la como pressuposto onipresente de minhas reflexões no campo da análise poética. Antes de mais nada, o fato de que não se trata de um sistema concluso e definitivo, com pretensão de exaurir de uma vez por todas a essência da arte, mas de uma filosofia que, ao mesmo tempo em que mantém o seu caráter especulativo, mantém igualmente o indispensável contato com a experiência concreta da arte. Em segundo lugar, a sua postura não normativa em relação ao seu objeto de investigação, coisa rara, mesmo em prestigiadas teorias filosóficas contemporâneas, que se apresentam, muitas vezes, como verdadeiras "poéticas travestidas", quer dizer, propõem-se como estéticas, como teorias explicativas da arte e sua experiência, mas, na verdade, procedem como poéticas ${ }^{49}$ : prescrevem normas operativas para os artistas, estabelecem como a arte deve ou não deve ser, o que deve ou não deve sugerir, se deve voltar-se para o real ou manter-se na abstração, se deve ser compromissada ou de evasão, e por aí afora. Ora, conquanto tal

\footnotetext{
${ }^{48}$ Nessa fase especulativa, que se interrompe com a morte do filósofo, em 1991, o problema do mal ganha preeminência, sendo pensado em sua autêntica natureza de positiva renegação da verdade. A inexauribilidade do ser é relacionada à sua essência conflitual, quer dizer, ao fato de que o ser carrega em si, como marca indelével, uma ambiguidade originária. Daí decorre o risco supremo e constitutivo da interpretação, a saber, a possibilidade de negar-se na sua natureza de vínculo veritativo e com isso deixar de existir.

49 Nesta acepção, o termo poética designa a proposta operacional de um artista (ou de um período ou escola artística), não um sistema de normas genéricas do fazer poético em geral. Sobre o sentido desse termo, Cf. PAREYSON, 1991. p.297-306; PAREYSON, 1997. p.15-19; ECO, 1976. p.24-5.
} 
procedimento seja legítimo no âmbito dos programas artísticos, é inadmissível no campo da estética, cuja tarefa precípua é a explicação desse campo de experiência, e não a sua regulamentação. ${ }^{50}$

O ponto de partida de Luigi Pareyson é a noção de que a vida humana possui caráter essencialmente formativo, ou seja, é produtora de formas que, nos mais diversos campos, são criações orgânicas, dotadas de acabamento, compreensibilidade e exemplaridade. Nasce daí a sua proposição básica de que, mais do que um conhecer, um contemplar ou um exprimir, a arte é um fazer; não um fazer como outro qualquer, mas “... um tal fazer que, enquanto faz, inventa o por fazer e o modo de fazer [...] uma atividade na qual execução e invenção procedem pari passu, simultâneas e inseparáveis, na qual o incremento de realidade é constituição de um valor original."

O fio condutor dessa teorização é a satisfação de três exigências, apontadas como fundamentais para a superação, tanto do formalismo quanto do conteudismo, enfoques teóricos unilaterais, que comprometem a plenitude e a autonomia da obra de arte, separando arbitrariamente o que lhe é congênito, coessencial e indivisível.

As exigências são as seguintes:

1) especificar a arte;

2) explicar a cota de artisticidade presente nas atividades comuns;

3) explicar a presença das outras atividades na arte.

\footnotetext{
${ }^{50}$ Cf. PAREYSON, 1997. p.15-17.

${ }^{51}$ PAREYSON, 1997. p.26. (Grifos do autor).
} 
A primeira exigência se resolve com a definição da arte como formatividade pura, específica e intencional, ou seja, como operação que tem por fim a produção de uma forma que vale por si, sem se subordinar à realização de algum outro fim ou valor. A segunda, com a lembrança de que a formatividade é uma nota extensiva a todas as operações humanas. E a terceira com a observação de que a especificação da formatividade na arte não supõe um exercício exclusivo dessa atividade, pois, pelo contrário, a formatividade só se especifica arrastando consigo todas as demais atividades que constituem a vida espiritual do artista, de modo que os valores e funções que a obra acolhe, nela se introduzem internamente ao gesto humano que a origina, portanto, já sob a forma de arte. ${ }^{52}$

Sobre essa base explicativa, Pareyson pode desenvolver sua teoria e reconhecer a arte: de um lado, como um fato hermenêutico (no sentido de que seus produtos resultam da interpretação que o artista faz de toda a realidade que envolve o seu ato e vivem doravante dentro dos atos interpretativos a que se oferecem); do outro, como um fato ontológico (não apenas porque o modo de formar é sempre pessoal, e, como a pessoa está em relação com o ser, mas também porque a transformação da matéria e dos

\footnotetext{
${ }^{52}$ Pareyson fundamenta sua explicação no que ele chama de estrutura geral do operar humano, da qual destaca dois princípios básicos, responsáveis pela distinção-unidade das atividades: a) cada operação, segundo o fim que lhe é próprio, especifica-se em relação às demais pelo exercício intencional e preponderante de determinada atividade espiritual; b) essa especificação, entretanto, não se dá nunca de modo exclusivo, pois a atividade especificada arrasta consigo toda a vida mental, direcionando-a para o seu êxito. O que imprime inconfundível direcionamento ao processo de concretização das atividades espirituais em operações é a acentuação intencional de uma delas e, ao mesmo tempo, o fato de que, no próprio ato dessa especificação, ocorre a participação obrigatória de todas as outras, que embora na condição de subordinadas aos fins da operação em questão, preservam seu peculiar caráter e o exercício de suas próprias funções. Em sua análise da teoria da formatividade, Umberto Eco assim descreve o funcionamento dessa hierarquia funcional que rege a especificação da arte: "Numa operação artística, intervém uma moralidade (... como compromisso que leva a sentir a arte como missão e dever, e impede totalmente que a formação siga outra lei que não seja a da própria obra a realizar): intervém o sentimento (entendido não como ingrediente exclusivo da arte, mas como coloração afetiva que o compromisso artístico assume, e no qual se desenvolve), e intervém a inteligência, como juízo contínuo e vigilante, consciente, que preside à organização da obra, controle crítico que não é estranho à operação artística... mas movimento inteligente em direção à forma, pensamento realizado no interior da atuação formante e destinado à
} 
conteúdos espirituais, que aí tem lugar, institui e funda um sentido novo, uma nova realidade, um novo ser).

A obra de arte é concebida como uma organicidade dotada de legalidade interna, que contém em si tudo quanto deve conter, dispensando qualquer referência externa para ser compreendida. E isto porque o conteúdo se introduz na obra como estilo, modo de formar, daí decorrendo que a forma — entendida como "matéria formada" - é, de per si, "conteúdo expresso". Ou seja, considerando-se a forma como sinônimo de "matéria formada" e o conteúdo como o singular e irrepetível "modo" pelo qual essa matéria assim se apresenta, o que daí se depreende é a total imanência do sentido ao sensível, por conseguinte, a perfeita unidade e indivisibilidade da obra. Significado humano e significado artístico, conteúdo artístico e conteúdo pré-artístico, fisicidade e espiritualidade são aspectos que aí coincidem plenamente:

\begin{abstract}
"Sinal físico e sentimento expresso, aspecto sensível e substância espiritual, símbolo físico e significação metafísica são elementos que, na arte, se apresentam de modo indissociável. Aquilo que é profundo não é o que se encontra atrás ou dentro, sobre ou além do aspecto sensível da obra, mas é o seu próprio rosto físico, todo evidente na sua definitiva consistência material, inexaurível, no entanto, na sua insondável dimensão espiritual: 'geheimnisvoll offenbar' como diria Goethe, isto é, misterioso e patente a um só tempo." 53
\end{abstract}

Avançando mais um ponto, a obra de arte, enquanto "forma acabada", una e indivisível, é o resultado de um processo que se caracteriza pela tensão entre os elementos que o constituem, mas que tendem sempre à unidade: a vida espiritual, que se torna o próprio estilo, na medida em que o procura e se faz gesto formativo; a intencionalidade formativa, que só é verdadeiramente tal quando se incorpora à matéria escolhida; o 
modo de formar, que só se define formando a matéria — a qual, por sua vez, só passa a pertencer à arte como matéria formada.

Mas essa unidade indivisível só se evidencia e ganha sentido quando considerada como resultado de um longo e complexo processo de pesquisa, tentativas, êxitos e fracassos, no qual a vida espiritual do artista define a sua vocação formal fazendo-se estilo. É a impossibilidade de se dissolver essa íntima conexão, ou melhor, a coincidência de humanidade e estilo na arte — característica essencial decorrente do dinamismo da arte, da sua gênese interior — que assegura sua autonomia.

Como se vê, a legalidade autônoma da forma não anula a personalidade concreta do autor, e isto se explica em razão da feição "pessonalista" da teoria pareysoniana: a feitura da obra é guiada pela sua própria lei interna, a qual, entretanto, só realiza suas virtualidades e chega ao êxito quando é devidamente cultivada e interpretada pelo autor. Em outras palavras, o processo produtivo, desde o seu momento embrionário, configura-se como uma dialética entre intencionalidade formativa do autor e intencionalidade natural da forma, de modo que o embrião da forma, o ponto de partida (spunto), só se desenvolve e atinge o êxito (riuscita), se é bem interpretado. ${ }^{54}$

Repare-se, ainda, que isto confere ao processo artístico um caráter aventuroso: trata-se de uma sucessão de tentativas, que tanto podem atingir o êxito, quanto redundar em fracasso. Tudo depende da iniciativa do artista, que tanto pode conceder à lei interna da forma uma escuta competente e leva-la à sua plenitude, quanto pode sobre-

\footnotetext{
${ }^{54} \mathrm{O}$ ponto de partida pressupõe um crescimento orgânico, mas só se torna fecundo se o artista o captura e faz seu, ou seja, se "... faz da coerência postulada pelo ponto de partida, a sua própria coerência, e, das várias direções a que pode aspirar, escolhe a que lhe é congenial e que, por isso, será a única realizável." ECO, 1981. p.19.
} 
por-lhe realizações indevidas ou deixar de perceber suas possibilidades de expansão e leva-la ao falimento.

Uma vez concluído, o processo formativo se atualiza, simultaneamente, como resultado, êxito de tentativas; memória viva do movimento de sua produção; estímulo e norma de infinitas reações interpretativas e fruitivas. Dentre outras coisas, isto significa que o êxito (riuscita) não é sinônimo de fechamento da forma em si mesma: ela inclui em si o seu processo e, num só ato, o conclui, abrindo-se ao mesmo tempo a infinitas perspectivas e desenvolvimentos, que constituirão a sua vida através da história.

Diante desse caráter dinâmico e processual da forma artística, o que se requer, da parte do leitor, é uma consideração também dinâmica e processual. Quer dizer, um olhar que saiba penetrar a sua trama orgânica e resgatar a lei íntima que presidiu à sua feitura, e que doravante se impõe como único critério legítimo de todas as suas interpretações, fruições e desenvolvimentos.

Essa viagem pela trama orgânica da obra implica, naturalmente, ter em conta o caráter necessário de cada uma de suas partes (em sua íntima conexão interna, entre si e com o todo) e, ao mesmo tempo, a presença viva da obra toda inteira em cada um de seus elementos constitutivos.

Para esclarecer este ponto, recorda Pareyson que, como todo organismo, a obra compõe-se de partes, cada uma das quais possui uma colocação determinada e insubstituível dentro do contexto, relacionando-se umas com as outras e com o todo de tal modo que entre elas se estabelece uma indissolúvel unidade. Mas, se isto ocorre, é porque, como já foi dito na Introdução, cada uma é instituída como tal, pelo todo, e, 
desse modo, o revela por inteiro — “... l'armonia delle parti forma l'intero perché il tutto fonda la loro unitá" ${ }^{55}$. Conclusão: tanto é possível alcançar o todo percorrendo as partes e considerando o nexo existente entre elas, quanto colher, em cada parte, aquele todo que as reúne em sua unidade.

Pelo que até aqui foi dito, já se pode perceber que o momento interpretativo não é concebido por Luigi Pareyson, nem como uma entrega passiva à obra (um anularse do leitor para que apenas a obra possa falar), nem como uma intervenção ativa (que force a obra dizer o que não quer). Trata-se, antes, de saber fazer a obra falar (de um ponto de vista pessoal, evidentemente, mas com sentidos que lhe pertencem), o que implica, mais uma vez, a exigência de uma consideração ativa e receptiva, indivisivelmente.

A própria obra impõe-se, desse modo, como lei e critério de sua interpretação — não como um critério externo e objetivo, evidentemente, mas como um critério interno, que só se define e revela sua força dentro dessa relação, acolhendo as interpretações verdadeiras e recusando as descaracterizadoras.

É fácil perceber que também não se trata de buscar a intenção do autor (como é o pensamento de certa hermenêutica, radicada em Schleiermacher), mas, fundamentalmente, de entrar em sintonia com a intenção da obra.

Tampouco se trata de pensar a relação interpretativa em termos de determinismo (metafísico ou sociológico): como já foi dito, a pessoa é sempre ativa e receptiva, indivisivelmente; em outras palavras, “... nulla può influire sull’attività responsabile

\footnotetext{
${ }^{55}$ PAREYSON, 1991. p. 107. T. A.: “... a harmonia das partes forma o inteiro porque o todo funda a sua unidade".
} 
dell'uomo se non è accolto e adottato all'interno d'un'operazione consapevole e emergente". 56

Fica igualmente afastada a presunção de que a leitura ideal seria a que pudesse conjugar as diversas interpretações, somando-as numa hipotética "leitura total", como se cada uma fosse parcial e insuficiente. Como foi visto linhas atrás, as interpretações diversas não são "aproximações" ou "partes" de uma suposta "verdade total". Cada ato interpretativo é, de per si, uma totalidade, no sentido de que, se por um lado, põe ênfase em determinado aspecto, acarretando o obscurecimento de outros, por outro, em cada um desses aspectos, a obra se realiza inteira, cada vez sob um ponto de vista. Isto ocorre tanto no plano da leitura "crítica", quanto no da leitura entendida como "execução" da obra (cada execução é uma interpretação e supõe uma interpretação). Veja-se, por exemplo, na declamação de um poema, quando se executa certas passagens deste e não daquele modo, que todavia é adotado em outra declamação: em cada um desses aspectos diversamente acentuados, a obra se realiza inteiramente, cada vez sob uma nova luz.

Sintetizando: a obra vive inteiramente no interior de cada uma de suas interpretações, mas como inexaurível, reservando-se a sempre novas perspectivas que ela própria suscita e solicita como seu único modo de viver. Recorde-se que Pareyson está a falar de autênticos atos interpretativos, quer dizer, daqueles que tomam por critério a própria obra, buscando compreendê-la de um determinado ponto de vista, que é sempre pessoal, evidentemente, mas nem por isso parcial, pois contém a obra em toda a sua inteireza. 
Pode-se então dizer que cada interpretação é definitiva com respeito às demais, pois cada uma constitui um modo singular e irredutível de penetrar a obra. Mas, com respeito a si mesma, cada uma é provisória, no sentido de que pode sempre ser corrigida e aprofundada pelo mesmo intérprete ou por outro, segundo graus infinitos de compreensão. Ressalte-se, nesta concepção, o papel axial do conceito existencialista de fracasso, entendido como um risco inerente à própria condição da pessoa: no processo interpretativo, a pessoa tanto pode tornar-se uma adequada "via de acesso", um verdadeiro "órgão de conhecimento", quanto restringir-se à mera expressão pessoal — e, nesse caso, nem mesmo se pode dizer que há interpretação, pois trata-se da própria negação do ato interpretativo.

Para finalizar, é fundamental relembrar, mais uma vez, a já mencionada tese pareysoniana de que, embora seja ineliminável, em todo discurso, a subsistência de um não dito, nem sempre este se apresenta como um resíduo subentendido e passível de enunciação e explicitação. No discurso comum, sim, estando o não dito fora da palavra, é possível explicitá-lo. Mas não é este o caso do legítimo discurso poético, onde o não dito se apresenta essencialmente como um implícito, portanto, como um sentido interno à palavra, que não pode ser explicitado, pois é antes estímulo inesgotável de revelação.

Em suma, o que esse tipo de discurso requer é interpretação, forma de conhecimento cuja perfeição desejável não consiste numa presumida explicitação completa ou numa enunciação definitiva (o que significaria acrescentar-lhe algo de estranho), mas na manifestação de uma origem inesgotável. Lamentar uma sua presumida insuficiência significa não compreender a sua natureza e tomar por defeito ou privação aquilo

\footnotetext{
${ }^{56}$ PAREYSON, 1985. p.241. T. A.: “... nada pode influir sobre a atividade responsável do homem se não é acolhido e adotado no interior de uma operação consciente e emergente".
} 
que é, pelo contrário, a sua perfeição e a sua essência. Se não se pode pretender uma explicitação definitiva e absoluta, não é porque a interpretação seja, necessariamente, "parcial”, insuficiente, mas porque o seu objeto é, por essência, inexaurível.

\subsection{A filosofia cética: do pirronismo ao relativismo novecentista}

O ceticismo, enquanto corrente de pensamento primordialmente voltada para a questão do conhecimento e sua possibilidade, surge na cena filosófica por volta de 300 a. C., na Grécia, compartilhando, portanto, o mesmo ambiente especulativo que o estoicismo (fundado por Zenon de Cítio) e o epicurismo (fundado por Epicuro de Samos). Tentando estabelecer uma rápida distinção entre essas três correntes de pensamento, podemos dizer que o epicurismo e o estoicismo se voltam de modo mais intensivo para as questões da esfera moral, enquanto o ceticismo se volta mais acentuadamente para a questão do conhecimento.

A reflexão ética dos epicuristas e dos estóicos se desenvolve sobre uma base epistemológica marcantemente sensualista. A sensação é, para eles, a base de todo conhecimento. Contudo, é preciso ressalvar que, se para Epicuro, a sensação imediata é um dado objetivo, um caminho seguro para a verdade ${ }^{57}$, para os estóicos, há uma maior exigência de critérios investigativos. O conhecimento começa na sensação, dizem eles, mas passa pela "representação" (phantasia), a qual tanto pode ser verdadeira ou falaz. Os juízos representam uma tomada de posição do sujeito diante da realidade objetiva: se são concordantes com essa realidade, são verdadeiros, se não, são falsos. Os conceitos

\footnotetext{
57 “A falsidade ou o erro está sempre no juntar-se de uma opinião” (EPICURO et al., 1973. p.22).
} 
são simples nomes comuns, resumem um conjunto de sensações ou representam um grupo de indivíduos mais ou menos semelhantes, não exprimem a natureza universal. É preciso, pois, descobrir critérios capazes de assegurar a distinção entre o falso e o verdadeiro.

Justamente contra essa busca do critério legítimo para a distinção do verdadeiro e do falso, interpõe-se o ceticismo. O seu argumento é bem conhecido: a toda razão opõe-se uma outra de igual valor, sendo, pois, impossível definir um critério único de conhecimento, ou seja, um critério que permita decidir sobre a verdade ou falsidade de um juízo. Assim sendo, tem-se uma situação de impasse, de dúvida incontornável, diante da qual, a única atitude plausível é a epoché, expressão geralmente traduzida por suspensão do juízo.

Dentro da filosofia cética antiga, costuma-se distinguir, duas correntes:

— o pirronismo, fundado por Pirro de Élis, tido como a forma mais rigorosa de pensamento dubitativo: o verdadeiro pirrônico duvida sempre se sabe ou não sabe, escreve Sexto Empírico $^{58}$, por conseguinte, não afirma nada, nem mesmo que nada sabe (pois isto seria incorrer numa forma de dogmatismo, o dogmatismo do não-saber) ${ }^{59}$ note-se, contudo, que essa disposição de reserva total implica uma atitude permanentemente inquisitiva diante da vida (a propósito, é útil lembrar que o termo ceticismo significa busca, procura, exame cuidadoso).

\footnotetext{
${ }^{58}$ A exemplo de Sócrates, Pirro de Élis nada escreveu. Suas idéias e comportamentos são relatados por seus seguidores, notadamente por Sexto Empírico e Diógenes de Laércio. Sexto Empirico, especialmente, oferece uma sistemática compilação dos argumentos pirrônicos, cuja leitura foi bastante difundida durante a Renascença, sendo base, por exemplo da meditação de Montaigne.

${ }^{59}$ Cf. SEXTO EMPÍRICO apud AUBENGUE, in: CHÂTELET, 1973. p.196, v.I.
} 
— o academicismo, liderado por Arcesilau e Carnéades de Cirene, menos rigoroso quanto à manutenção do caráter dubitativo da proposta cética original (admite o uso de critérios de crença puramente subjetivos e o atendimento das exigências da natureza).

Sobre a natureza da époche, observa Danilo Marcondes que esse conceito é definido por Sexto Empírico pelo verbo anairéo, com isso indicando que “... o pensamento (dianoia) se encontra em suspensão (anairein) pela impossibilidade de decidir dada a equivalência (isosthenia) das posições em questão."60 O verbo "suspender", prossegue o autor citado, “ ... pode ser entendido aí exatamente como sustar, interromper um processo, reter o impulso de julgar com base nas impressões que se tem, exatamente porque as impressões não permitem um juízo, uma decisão sobre a verdade e a falsidade. ${ }^{, 61}$ Esse estado de suspensão não implica, portanto, “... que não se possa considerar algo, mas sim que não se passa da consideração à deliberação sobre a verdade e a falsidade, interrompendo-se o processo.” Em suma, trata-se de uma “... ausência de compromisso com a verdade de um determinado conteúdo proposicional, a abstenção de uma tomada de posição."62

\footnotetext{
${ }^{60}$ MARCONDES, 1996. p.16.

${ }^{61}$ MARCONDES, 1996. p.16.

${ }^{62}$ MARCONDES, 1996. p.17.
} 
A rigor, pois, o ceticismo difere do niilismo, na medida em que este implica uma postura de negação e recusa de realidades ou valores consagrados ${ }^{63}$, enquanto o primeiro não afirma nem nega nada (negar seria também uma forma de dogmatismo). Difere, também, do relativismo, o qual, como o próprio nome indica, caracteriza-se pela relativização do conhecimento a um dado parâmetro, logo, implica a admissão de um critério, coisa que o ceticismo propriamente dito recusa.

Naturalmente, a atitude dubitativa, professada tanto pelos pirrônicos quanto pelos acadêmicos, não constitui uma novidade na história da filosofia, nem fica restrita apenas ao âmbito dessas duas escolas de pensamento.

Já com Heráclito e sua doutrina do logos (pela qual Fernando Pessoa tinha significativo interesse ${ }^{64}$ ), desencadeara-se uma longa meditação sobre a essência con-

\footnotetext{
${ }^{63}$ Nesse sentido mais amplo, designam-se como niilistas, por exemplo, as doutrinas de: Górgias de Leontium, David Hume e do último Nietzsche. No caso de Nietzsche, ele próprio usou o termo para qualificar sua radical oposição aos valores vigentes em sua época (morais, metafísicos, religiosos): "O niilismo não é somente um conjunto de considerações acerca do tema 'tudo é vão', não é somente a crença em que tudo merece morrer, mas consiste em pôr as mãos na massa, em destruir... É o estado dos espíritos fortes e das vontades fortes, aos quais não é possível ater-se a um juízo negativo: a negação ativa responde melhor às suas naturezas profundas”. (NIETZSCHE apud ABBAGNANO, 1994. p.854).

${ }^{64}$ A título de ilustração, transcrevo uma passagem pessoana, onde ele reflete sobre a doutrina de Heráclito: "Diz Heráclito que como todas as coisas estão em permanente mudança nenhum conhecimento é possível. A minha resposta será que se todas as coisas variam eu também vario, e portanto estou numa relativa estabilidade. $\mathrm{O}$ sujeito e objeto variando perpetuamente são estáveis em relação um ao outro. O mundo está apenas em variação perpétua quando em contraste com algo imutável. [...] Tudo é mudança. Verdade. Mas se há apenas mudança, esta mudança deve ocorrer em alguma coisa. Esta alguma coisa é o que chamamos substância, Ser." (PESSOA, 1995. p.537-40).
} 
traditória da realidade, enquanto coexistência de contrários ${ }^{65}$, e sobre o poder da razão humana de compreender essa diversidade ${ }^{66}$.

No séc. V a.C., os sofistas Protágoras e Górgias acirram a desconfiança da possibilidade humana de distinguir entre o verdadeiro e o falso, firmando suas célebres artimanhas retóricas sobre a noção de equipolência dos opostos. Contudo, o seu encaminhamento é de cunho relativista. Em Protágoras, especialmente, há uma primeira sistematização do relativismo: as coisas são para nós conforme nos aparecem, diferindo de pessoa para pessoa, segundo as circunstâncias particulares; não há critério objetivo — o homem é a medida de todas as coisas. Quanto a Górgias, suas teses se incluem, com mais propriedade, no niilismo, já que não apenas nega a possibilidade do conhecimento universal, mas também a possibilidade de comunicação de um para outro (cada expressão verbal traduz em sons a experiência dos outros sentidos, e quem a ouve tem que cumprir a tradução inversa, o que não pode fazer sem ter já o conhecimento que se quer comunicar-lhe). ${ }^{67}$

${ }^{65}$ Cf. HERÁCLITO, Frg. 8, 51, 53: “... o contrário é convergente e dos divergentes nasce a mais bela harmonia, e tudo segundo a discórdia” ; “... o divergente consigo mesmo concorda; harmonia de tensões contrárias, como de arco e lira"; "A guerra é o pai de todas as coisas ....".

66 Sobre a doutrina heracliteana, escreve António Pina Coelho, ressaltando sua influência sobre Pessoa: "A essência da realidade é o vir-a-ser, o fogo, num fluxo eterno, um revezar-se de vida e de morte, uma luta ou oposição que são reconduzidos à estabilidade e à unidade pela harmonia e sabedoria universais." (COELHO, A. P. 1971. p.50.).

${ }^{67}$ Sobre o niilismo de Górgias, lê-se num manuscrito de Fernando Pessoa: "Nada existe. Se alguma coisa existir deve ser eterna. [...] O que é eterno é infinito: o Ser infinito não existe nem no tempo nem no espaço, o que o limitaria 'tour a tour' (em toda a sua extensão). Não existe em parte alguma, e o que não está em parte alguma, não existe. Se (o que é impossível) alguma coisa existisse, nós não poderíamos conhecê-la. E, se conseguíssemos tomar conhecimento dela, não poderíamos comunicar esse conhecimento a outros." (PESSOA, 1995. p.540). 
Não me estendo a respeito dessas escolas gregas de pensamento dubitativo. Apenas chamo a atenção para o fato de que não se pode identificá-las com a atitude que caracterizará o ceticismo, posteriormente, na época do helenismo.

O problema cético por excelência não é a existência ou inexistência das coisas, mas a equipolência dos argumentos diversos com respeito à sua verdade ou falsidade e, por conseguinte, a necessidade de uma atitude de suspensão de todo e qualquer julgamento. Segundo Sexto Empírico, o princípio cético assim se resume: é “... zetético, da ação de investigar e indagar; suspensivo pela disposição de ânimo que conserva com referência ao objeto indagado; e dubitativo por seu duvidar e investigar acerca de todas as coisas" $"$.

Note-se, no entanto, que, mantendo a epoché, o que o cético tenta alcançar é um certo tipo de ataraxia, de tranquilidade espiritual, que não é extensiva à vida em geral, mas é uma tranqüilidade epistêmica, quer dizer, decorrente da supressão do problema da verdade. ${ }^{69}$

É essa direta vinculação à esfera intelectual que distingue, essencialmente, a ataraxia dos céticos, em relação à dos epicuristas e dos estóicos. Para o cético, a paz mental liga-se a um estado de aphasia, de não-asserção, ou seja, decorre da disposição de não tomar partido por coisa alguma, de não afirmar ou negar nada, mantendo-se em estado permanente de investigação e suspensão do juízo. Para os epicuristas, a ataraxia tem um sentido predominantemente hedonista. Entenda-se, no entanto, que Epicuro não está se referindo a prazeres imediatos, passageiros, “... aos prazeres dos intemperantes

\footnotetext{
${ }^{68}$ SEXTO EMPIRICO apud ABBAGNANO, 1994. p.1205.

${ }^{69}$ SMITH, 1995. p.288.
} 
ou aos produzidos pela sensualidade [...] mas ao prazer de nos acharmos livres de sofrimentos do corpo e de perturbações da alma" ${ }^{\text {70 }}$. A ataraxia, lembra ele, é “... princípio e fim da vida feliz [...] primeiro e inato bem",71, correspondendo à busca do grau mínimo de dor, ao abandono de crenças incômodas, como a da vida após a morte ("Habitua-te a pensar que a morte nada é para nós, visto que todo o mal e todo o bem se encontram na sensibilidade: e a morte é a privação da sensibilidade" ${ }^{\text {,72 }}$ ) e a do poder divino de intervir na vida humana. Para os estóicos, a ataraxia percorre a via da virtude, da disciplina de si mesmo, tendo como valor essencial a resignação e a abstenção: "Suporta e abstémte", é a sua máxima bem conhecida. O homem, embora possa orientar-se pela razão, é inteiramente impotente em relação ao fatum (fatalidade). A razão apenas lhe subministra normas de ação, mas não lhe dá o poder de mudar o rumo dos acontecimentos. Em suma, o seu papel é de simples "persona”, ator e personagem de sua própria existência.

Há uma difundida idéia de que, durante a Idade Média, por força da religiosidade preeminente, teria ocorrido um total desinteresse pelo pensamento dubitativo expresso nos textos do helenismo grego. Todavia, o que de fato ocorreu, em boa parte dos casos, foi uma mudança de orientação: os argumentos contra a razão foram invocados no sentido de reforçar a certeza fundada na segurança da fé em Deus, de modo que, ao contrário do que se poderia pensar à primeira vista, os textos do ceticismo grego foram retomados como preciosos auxiliares da argumentação em prol das verdades da fé.

\footnotetext{
${ }^{70}$ EPICURO et al., 1973. p.25.

${ }^{71}$ EPICURO et al., 1973. p.25.

${ }^{72}$ EPICURO et al., 1973. p.21.
} 
No século XIV, registrou-se mesmo um certo revigoramento da atitude cética, motivado, em boa medida, pela difusão dos questionamentos nominalistas de Guilherme de Ockham contra os conceitos da metafísica racionalista: a verdadeira ciência, defendia ele, deve trabalhar com as coisas em sua verdade singular; só a experiência empírica pode comprovar a verdadeira realidade das coisas; os universais não têm realidade objetiva, existem apenas no intelecto, não se referem às coisas, mas aos conceitos, e estes são meros signos, simples artifícios, privados de existência real, baseados em abstrações.

Mas foi durante os séculos XVI e XVII, principalmente com Michel de Montaigne (1533-1592) e Blaise Pascal (1623-1662), mas também com pensadores não tão conhecidos, como o português Francisco Sanchez (1552-1632), que a descrença dos poderes da razão humana se intensificou, ganhando um peso filosófico realmente decisivo. $^{73}$

Montaigne, como se sabe, procurou demolir superstições, investiu contra o dogmatismo, denunciou a fragilidade do conhecimento humano (enganado tanto por seus sentidos, quanto por sua razão, o homem não pode conhecer nada, nem a si mesmo nem à realidade à sua volta). Sua fórmula famosa — "Que sais-je?” — expressa-se justamente como uma interrogação, pois, dizer: "Je ne sais pas”, seria, afinal, fazer uma afirmação, coisa incongruente com o princípio cético. A revelação e a graça são os únicos meios para o homem de superar a deficiência do seu modo de conhecer.

\footnotetext{
73 De Pascal e Sanchez, segundo António Pina Coelho (1971. p.52 notas 4 e 8), há referências nos apontamentos inéditos de Fernando Pessoa.
} 
Pascal, o filósofo do paradoxo, postulou, contra o racionalismo metafísico, que a verdade é sempre a reunião de contrários: "On ne montre pas sa grandeur pour être à une extremité, mais bien en touchant les deux à la fois, et remplissant tout l'entredeux." ${ }^{, 74}$ O homem, sobretudo, é um ser paradoxal e misterioso, explicável unicamente pela religião. A fé seria um modo de conhecimento, imediato e intuitivo, próprio do coração, o qual tem razões que não podem ser desacreditadas por meio da razão.

Embora bem menos divulgado, Francisco Sanchez mostrou-se um dos mais inflexíveis anti-racionalistas, combatendo duramente as proposições aristotélicas e aproximando-se notoriamente da postura característica do ceticismo pirrônico. Sua dúvida, de fato, radical, antecipa em certa medida a dúvida "hiperbólica" de Descartes (1596-1650), mas é preciso ter em conta que, entre ambos, há uma diferença primordial. De certo, trata-se, em Descartes, de uma dúvida "hiperbólica", mas não como uma convicção permanente, como é o caso de Francisco Sanchez. A dúvida cartesiana é de natureza diversa: é uma dúvida metódica, invocada como estratégia especulativa destinada à realização do saber total, especular, indubitável. A suspensão do juízo não passa aí de uma estratégia preparatória para o momento que se põe como triunfante dentro do seu sistema, a saber, o Cogito ergo sum, certeza inicial, auto-evidente, cuja verdade não se apoia em nenhuma outra e que emerge da dúvida para se transformar no princípio filosófico primeiro. É, em última análise, a sua própria existência enquanto substância pensante (res cogitans), que se pensa a si mesma e que é o que é independentemente do corpo e do mundo, o que Descartes coloca como ponto de partida de sua busca da verdade. A razão, assim absolutizada, adquire um estatuto novo: consagra-se como o único

\footnotetext{
${ }^{74}$ Trecho de Pascal, transcrito por Jacinto do Prado Coelho no Prefácio de: PESSOA, 1973. p.XXI.
} 
órgão da verdade demonstrativa, o instrumento único, legítimo e incontrastável, para a investigação da verdade interna e externa ao sujeito, negando-se tudo o que vem pela via dos sentidos.

A teoria de David Hume (1711-1776), que se inclui entre as leituras de Fernando Pessoa, ${ }^{75}$ costuma ser destacada como a forma mais perfeita e acabada do ceticismo moderno. Surgida no século XVIII, época em que a especulação filosófica se mostra inteiramente dominada pelo problema da percepção, a teoria empirista de Hume proclama que a mente é uma "tabula rasa", onde só existem os dados derivados da experiência sensível. A origem das impressões sensíveis nos é completamente desconhecida, sendo sua causa última inexplicável. Conclusão: é impossível provar ou conhecer um mundo material a partir de nossas percepções; são destituídos de validade todos os conceitos ou idéias gerais, por não se referirem a dados concretos. Mas, note-se bem: não se trata, aqui, da atitude rigorosamente dubitativa e suspensiva. Esta é de todo impensável dentro do contexto reflexivo humeano, sabido adepto do pragmatismo. ${ }^{76}$

Para finalizar esta rápida revista das incidências do pensamento cético na filosofia moderna, é importante dizer alguma coisa sobre a doutrina de Kant (1724-1804), que embora não pertença ao filão da filosofia cética, de fato impõe uma drástica limitação ao entendimento humano. ${ }^{77}$ Sabe-se que, concordando parcialmente com Hume,

\footnotetext{
${ }^{75}$ Cf. levantamento de leituras e apontamentos pessoanos sobre David Hume e a escola empirista inglesa, de modo geral, em: COELHO, A. P. 1971. p.57.

${ }^{76}$ O próprio Hume se confessa predisposto a uma forma "atenuada", "mitigada", de ceticismo, segundo ele, mais próxima do academicismo (HUME, 1973. p.196-7).

${ }^{77}$ Segundo António Pina Coelho, Fernando Pessoa certamente leu Critique de la Raison Pure e Critique de la Raison Pratique, como podem comprovar as referências e indicações de páginas que ele faz em textos publicados e inéditos. Cf. COELHO, A. P. 1971. p.57.
} 
reconhece Kant que o homem só pode conhecer os fenômenos, sendo-lhe vedado o acesso ao noumenon (ou seja, ao que as coisas são "em si", independentemente da maneira como nos aparecem). Todavia, entende ele que as condições de possibilidade da experiência são inerentes à própria estrutura da sensibilidade e do entendimento humano, quer dizer, não são condições empíricas, mas transcendentais. Resumindo, todas as intuições se inscrevem em formas a priori - espaço e tempo - as quais compõem a estrutura da sensibilidade. Os conceitos derivam de "categorias" gerais, que compõem a estrutura do entendimento.

Passo em seguida a comentar o conturbado panorama filosófico do transpor do século XIX para o XX. A se identificar um denominador comum subjacente às correntes artísticas e literárias desse período, é forçoso concordar em que se trata de um contexto de eminente dissolução do sistema hegeliano do idealismo absoluto, sistema este que constituiu a forma culminante e mais elaborada do racionalismo metafísico moderno.

Resumindo brevemente, Hegel (1770-1831) coloca no centro de seu sistema o conceito de Espírito (Geist), concebido em sentido absoluto, quer dizer, para além dos limites da consciência individual: o Espírito é o resultado de todo um processo dialético necessário, de autodesdobramento, não é um infinito separado do finito, mas um infinito que engloba o finito e nele se realiza. Por outras palavras, não mais se trata daquela consciência subjetiva, cartesianamente entendida como princípio primeiro, evidência inicial, pura reflexividade e ponto de partida de todo conhecimento, mas da consciência absoluta, em permanente autodesdobramento, segundo um ritmo interno próprio, apurando-se a cada momento, até tornar-se onicompreensiva: cada momento dessa trajetória 
é habitado por uma contradição, a qual induz a sua superação (Aufhebung) num momento subseqüente, e assim por diante, até alcançar a verdade final, ou seja, a identidade de racional e real.

Como se pode notar, Hegel eleva ao seu mais alto grau o saber total. Todavia, concebe um sistema totalizante, incapaz de lidar com o outro, com o diverso de si mesmo, em sua alteridade. Trata-se de um sistema fagocitante, que constrói o absoluto à custa da destruição dos momentos particulares. Daí a crise, que, já em 1846, se denunciava como "decomposição" do "Espírito absoluto" e se descrevia como “... uma fermentação universal, em que são arrastadas todas as 'potências do passado'.,"78

Com efeito, a dissolução do sistema hegeliano é o humus substancial da crise que assola todo o edifício racionalista, a partir de então, passando as correntes filosóficas diversas a relativizar os valores não mais a um fundamento onipresente, mas às suas próprias circunstâncias ou condições temporais, o que significa, em última instância, uma redução das filosofias a uma indiferente multiplicidade de teorias, meramente aderentes ao seu contexto de origem.

Para muitos, esse relativismo, que então se difunde, é uma forma contemporânea de ceticismo. Todavia, como já foi dito anteriormente, a rigor, os dois âmbitos não se confundem.

Como foi mencionado no início desta seção, o ceticismo original preconizava uma postura permanentemente indagativa e rigorosamente suspensiva, atitude esta que não carateriza nem o relativismo nem tampouco o niilismo, proliferantes desde

\footnotetext{
${ }^{78}$ MARX e ENGELS apud RUSSO, 1993. p.15.
} 
meados do século XIX: o cético verdadeiro exclui a possibilidade de se subministrar qualquer critério de decisão entre o falso e o verdadeiro (por isso, não afirma nem nega), atitude diversa da niilista (que se caracteriza pela negação) e da relativista (que, de um modo ou de outro, estabelece um critério de conhecimento: o sujeito e seu tempo).

O tipo de relativismo que se desenvolve a partir da morte de Hegel e que se consolida ao longo do século XX tem algumas características peculiares, que devem ser consideradas.

Antes de mais nada, trata-se de um estado de espírito bastante difundido, que se manifesta em todos os campos da cultura. Embora não se possa desprezar o formidável impacto anti-racionalista e anti-totalizante de todo um conjunto de doutrinas filosóficas e científicas que florescem nesse período e que de modos vários opõem ao saber absoluto a unicidade irrepetível de cada momento, concentro minha atenção em três delas, justamente as que compõem o que Paul Ricoeur chama de "escola da suspeita" ${ }^{79}$, salientando a sua ação demolidora em relação à tradicional concepção do sujeito humano como autor de suas idéias e ações, desencadeando o que se convencionou chamar de "crise do sujeito". Trata-se como se sabe, das doutrinas de Marx (18181883), Nietzsche (1844-1900) e Freud (1856-1939).

Marx e Nietzsche denunciam a falsidade e superficialidade das formas definitivas e estáveis que alicerçam a sistematização conciliante da dialética hegeliana: são aparências sublimadas, dotadas de função consoladora e encobridora das verdadeiras forças motrizes dos atos humanos — para Marx, os determinismos sócio-econômicos;

\footnotetext{
${ }^{79}$ RICOEUR, 1965. p.42 et seq.
} 
para Nietzsche ${ }^{80}$, o fundo irracional das coisas e a falência do predicado racionalista da unidade do eu —, pois pressupõem ingenuamente que o conhecimento possa apreender o seu objeto como 'coisa em si', e que, nem da parte do sujeito nem da parte do objeto, ocorra uma falsificação. Escreve Nietzsche: “... las verdades son ilusiones que han olvidado su auténtica naturaleza; metáforas que han perdido su forma sensible; monedas en las que ha desaparecido el cuño y que, en consecuencia, ya no son consideradas como moneda, sino como metal". ${ }^{81}$ Freud vem por último, e é com ele que se desfere o golpe decisivo no primado da filosofia centrada no "sujeito pensante" cartesiano. Para se entender o verdadeiro impacto desse golpe, é preciso, antes de mais nada, recordar que, embora não seja Freud o "descobridor do inconsciente" (esta noção já era bastante difundida desde muito antes ${ }^{82}$ ), a noção de "inconsciente" que ele desvela — sobretudo a partir de "O Ego e o Id" (1923) — é algo inteiramente novo e perturbador: não se trata mais daquele conceito de inconsciente, entendido como uma dimensão obscura, inacessível à razão, situado aquém ou abaixo da consciência (logo, como sinônimo de "desconhecimento", de "não-saber"), mas do inconsciente entendido como instância ativa, atuante no interior do próprio Ego e dirigindo, na penumbra, as disposições mentais do sujeito.

\footnotetext{
${ }^{80}$ A propósito do conhecimento de Fernando Pessoa sobre Nietzsche, Cf. COELHO, A. P. 1971. p.59 nota 1.

${ }^{81}$ NIETZSCHE apud FERRARIS. Envejecimiento de la "escuela de la sospecha". In: VATTIMO, ROVATTI, 1990. p.170. T. da A.: “... as verdades são ilusões que esqueceram sua autêntica natureza; metáforas que perderam sua forma sensível; moedas cujo cunho desapareceu e que, em consequiência, já não são consideradas como moedas e sim como metal".

${ }^{82}$ Lembremo-nos de que já Leibniz tinha uma noção de inconsciente (petite perception), que ele entendia como algo que não chega ao umbral, que não é conhecido do ponto de vista da consciência.
} 
O inconsciente, demonstra Freud, não é o contrário, o absolutamente outro da consciência, da razão, mas o seu correlato, sendo ele, também, uma forma de pensamento, que se expressa de modo simbólico no discurso manifesto. A exploração da instância inconsciente liga-se, assim, a uma exigência de decifração, de "desmascaramento" dos fatores latentes nos discursos manifestos, o que, segundo Freud, pode ser feito através da análise do sonho, do ato falho e do chiste $($ Witz $){ }^{83}$

Isto posto, fica mais claro em que sentido se costuma falar de Freud como a figura em que se radicaliza a questão crucial da epistemologia novecentista e que se resume na seguinte pergunta:

— qual é o real estatuto do sujeito, uma vez que não mais se pode pensá-lo como senhor de seus próprios atos e pensamentos, ou seja, uma vez que se sabe agora que seus atos e pensamentos são governados por um sistema de regras e convenções de ordem simbólica, cuja ação ele desconhece?

Atenção, no entanto. Isto não significa que Freud seja um cético. Em momento algum, ele nega o sujeito ou a sua possibilidade. Ele nega, sim, a pretensão de uma perfeita auto-transparência, de uma translucidez do sujeito frente a si mesmo, de uma "evidência da consciência", pregando a necessidade de uma modificação substancial do que até então se entendia por sujeito e por verdade, mas não a eliminação de tais noções. A consciência não é evidente, ela não é um dado, mas, como diz Paul Ricoeur, ela é, antes, uma tarefa, “... a tarefa de tornar-se-consciência." ${ }^{, 84} \mathrm{O}$ primado da razão está

\footnotetext{
${ }^{83}$ Resumidamente, é o que Freud procura demonstrar em obras como: "Interpretação dos sonhos" (1900), "Psicopatologia da vida cotidiana" (1901), "O chiste e sua relação com o inconsciente" (1905), "Além do princípio do prazer" (1920) e "O Ego e o Id" (1923).

${ }^{84}$ RICOEUR, 1969. p.172-3.
} 
certamente muito distante, mas é possível triunfar sobre a dúvida através de uma exegese do sentido, ou seja, de um deslocamento do lugar de origem do sentido. Isso é, em última análise, um alargamento, uma extensão, do campo da consciência.

A noção freudiana de inconsciente altera de vez a conceituação precedente, baseada na noção racionalista do sujeito agente centrado em seu próprio eixo. Freud mesmo se refere a esse impacto, designando-o como o terceiro golpe infligido ao narcisismo universal do homem — o primeiro golpe, desferido por Copérnico, abala a ingênua crença do homem sobre a posição central da Terra e seu papel dominante no universo; o segundo, dado por Darwin, põe fim à falsa presunção humana de ocupar o centro do reino animal; o terceiro, que é o da própria teoria psicanalítica, expulsa o homem do centro de si mesmo, mostrando-lhe que não existe correspondência perfeita entre o que está em sua mente e aquilo de que ele está consciente: “O ego não é o senhor da sua própria casa". ${ }^{85}$

A esta altura, já se percebe que o que se abala com as descobertas de Freud é nada mais nada menos que o inteiro projeto desenvolvido ao longo de três longos séculos pela filosofia moderna, eminentemente centrada e respaldada na auto-evidência do cogito cartesiano, ou seja, na noção, mantida como verdade insofismável, de que a consciência é tal como aparece a si mesma, nela se verificando uma perfeita coincidência entre sentido e consciência do sentido. Com Freud, é a consciência, justamente, que se transforma no lugar da dúvida: “... é contra o próprio Cogito — ou antes, é no interi-

\footnotetext{
${ }^{85}$ FREUD, 1969. p.178.
} 
or do Cogito - que a psicanálise vem cindir a apoditicidade do Eu, das ilusões da consciência e das pretensões do Ego." ${ }^{\text {86 }}$

Note-se bem, e estou ressaltando isto pela segunda vez, que se Freud é reconhecido como inovador, isto se deve ao fato de que o conceito de inconsciente vigente até o momento em que ele iniciou suas pesquisas era bem diverso. Havia, sim, uma noção de inconsciente, inclusive largamente explorada pelas poéticas do romantismo, e convém ressaltar que o próprio Freud acolheu essa noção, inicialmente. Como já foi dito, tratava-se de um inconsciente concebido como um domínio irracional, paralelo, externo e inacessível à consciência, havia, em suma, nessa concepção anterior, um dualismo entre consciente e inconsciente. E é esse dualismo, justamente, que Freud vem eliminar, ao demonstrar que o inconsciente é uma instância que age internamente ao próprio Ego, mantendo uma tensão dialética constante entre o latente e o manifesto.

Face a essa comprovação freudiana de que o significado dos discursos humanos relativiza-se a outra instância, detentora do seu controle, debilita-se a convicção racionalista da transparência dos discursos. Desconfia-se doravante de que, para se identificar o significado verdadeiro de um discurso, é preciso considerá-lo não tanto pelo que ele diz, mas sobretudo pelo que manifesta involuntariamente, ou seja, não propriamente por suas conclusões explícitas, por seu alcance e coerência, mas primordialmente pela base inconsciente que a ele subjaz e que por ele se exprime: em Nietzsche, essa base inconsciente se apresenta como o fundo irracional das coisas; em Marx, como os determinismos sócio-econômicos; em Freud, como os determinismos internos ao próprio Ego.

${ }^{86}$ RICOEUR, 1969. p.172. 
Para finalizar, observe-se que o "desmascaramento" proposto pela "escola da suspeita" abre um intervalo intransponível entre o discurso explícito e o significado profundo. A palavra fica reduzida a mera construção conceitual, que não revela nem ilumina, mas pelo contrário encobre, esconde, significados que estão fora dela. Assim sendo, o aspecto explícito, entendido como pretensa revelação da verdade, está em franco contraste com o subentendido, a tal ponto que o significado do discurso deve ser buscado em outro nível, qual seja o da expressão inconsciente e mascarada das instâncias que de fato o conduzem: nesse sentido, compreender significa "desmascarar", quer dizer, levar o subentendido à completa explicitação.

Para o delineamento do contexto de pensamento em que se insere a poética de Fernando Pessoa, o que sobretudo importa relevar é a subsistência, em todo esse contexto, de um ideal de saber eminentemente relativista, anti-racionalista, mas ainda impregnado de hegelianismo, na medida em que a compreensão dos fenômenos particulares continua sendo feita por referência a um fundamento, que deteria o seu verdadeiro significado. $^{87}$

Resumindo, ao recusar a totalização hegeliana, o relativismo limita-se a negar a possibilidade de redução dos saberes singulares a um ponto de vista único e definitivo, mas mantém, como resíduo implícito irrenunciável, o pressuposto de que, para ser tal, o saber verdadeiro tem que ser absoluto, especular, definitivo. Assim sendo, embora negue explicitamente o ideal racionalista de saber total e definitivo, continua a pressupô-lo, implicitamente, como o único conhecimento que seria capaz de assegurar a vali-

\footnotetext{
${ }^{87}$ O primeiro a chamar a atenção sobre esse ponto é Luigi Pareyson, que, já em fins da década de quarenta, denunciava o aprisionamento do relativismo hermenêutico num horizonte epistemológico impregnado de resíduos hegelianos.
} 
dez especulativa da filosofia, ou seja, simplesmente ricocheteia para o polo oposto ao hegelianismo, continuando a dividir com este um solo comum, ancorado no pressuposto da totalidade e no ideal da explicitação.

Conclusão: ambos são, de fato, as duas faces da mesma moeda, posições simétricas e complementares, que se sustentam nos mesmos pressupostos equivocados: a) que o saber verdadeiro, para ser tal, tem que ser absoluto, especular; b) que o conhecimento pessoal é a esfera do engano e do erro. Não por outra razão, a negação relativista do saber total confina, forçosamente, na supressão da verdade e da própria filosofia. 


\section{A POÉTICA PESSOANA: DIRETRIZES ESTILÍSTICAS E FILO- SÓFICAS}

Os comentários que teço neste capítulo têm por objetivo oferecer uma visão geral das principais direções estilísticas e filosóficas que norteiam o poetar de Fernando Pessoa.

Tratando-se de uma obra poética que, a par da sua riqueza estilística, destaca-se por um inequívoco alcance filosófico, elejo como ponto de partida uma conhecida passagem de seu autor, datada provavelmente de 1910, em que o mesmo se auto-define: "Era eu um poeta estimulado pela filosofia e não um filósofo com faculdades poéticas". ${ }^{1}$

\subsection{Fernando Pessoa: “... um poeta estimulado pela filosofia ..."}

Para alguns, ao optar por definir-se como "um poeta estimulado pela filosofia" e recusar a qualificação de "filósofo com faculdades poéticas", Fernando Pessoa estaria, de algum modo, minimizando o alcance filosófico do seu poetar. No entanto, não é esse, com certeza, o seu intento. Pelo contrário, se há um poeta em que a meditação filosófica é uma atividade essencial e perfeitamente consciente, esse poeta é, sem dúvida, Fernando Pessoa. Haja visto, apenas à guisa de exemplo, um de seus instigantes

\footnotetext{
${ }^{1}$ PESSOA, 1995. p.36. (Grifo meu).
} 
poemas, datado de 1933, cujo teor é justamente a dualidade que envolve o pensar e o sentir dentro do poetar:

[165]

Tenho tanto sentimento

Que é freqüente persuadir-me

De que sou sentimental,

Mas reconheço, ao medir-me,

Que tudo isso é pensamento,

Que não senti afinal.

Temos, todos que vivemos,

Uma vida que é vivida

E outra vida que é pensada,

$\mathrm{E}$ a única vida que temos

É essa que é dividida

Entre a verdadeira e a errada.

Qual porém é verdadeira

E qual errada, ninguém

Nos saberá explicar;

E vivemos de maneira

Que a vida que a gente tem

É a que tem que pensar.

Atentando-se ao sentido profundo das inflexões estilísticas que se oferecem neste poema, pode-se perceber que poesia e filosofia aí se encontram em perfeita indivisibilidade, consubstanciadas plenamente no próprio modo como os versos e estrofes se organizam.

Repare-se, primeiramente, num detalhe aparentemente insignificante: a inversão do esquema rítmico, no quarto e quinto versos da primeira estrofe. As três estrofes que compõem esse poema organizam-se em grupos de seis versos, cujas rimas se distribuem, predominantemente, segundo o esquema $\mathrm{ABCABC}$, exceto na primeira estrofe, que segue o esquema $\mathrm{ABCBAC}$, invertendo-se, portanto, as posições das rimas. Essa simples inversão confere a esses versos não apenas uma posição ímpar dentro do 
poema, mas também um enriquecimento do significado: através da rima sentimento / pensamento, aproximam-se o primeiro verso e o quinto, conferindo relevo especial à relação que os interliga; o segundo verso e o quarto formam a única rima cruzada do poema, persuadir-me / medir-me, enfatizando a ocorrência de movimentos mentais auto-reflexivos. A rima aguda, sentimental (terceiro verso) e afinal (sexto verso), realça a aguda contraposição entre pensamento e sentimento.

Na segunda estrofe, o primeiro "enjambement" realça o dualismo vida "vivida" / vida "pensada", enquanto a rima subsequente — vivida (segundo verso) / dividida (quinto verso) - realça a restrição de sentido do primeiro termo do dualismo acima citado. É o parentesco sonoro que confere, mais uma vez, um sentido negativo, desta vez através da aproximação de pensada (terceiro verso) / errada (sexto verso). O segundo "enjambement" (do quarto, quinto e sexto versos) acentua a ambivalência de verdadeira e errada.

A terceira estrofe subdivide-se em dois segmentos iguais, compondo-se de dois "enjambements" de três versos cada um, ambos com a mesma distribuição interna. Note-se a importância das rimas, que interligam: verdadeira (primeiro verso) e maneira (quarto verso); ninguém (segundo verso) e tem (quinto verso); explicar (terceiro verso) e pensar (sexto verso).

É apenas um exemplo inicial, mas que já é bastante para ressaltar a maneira integrada como se exercitam o poético e o filosófico na obra de Fernando Pessoa. Mas, o que pretenderia ele, então, com a citada auto-definição?

De certo, não seria negar ou minimizar o alcance filosófico de sua poesia. Bem mais provável é a hipótese de uma antecipação sua a algum possível equívoco de 
seus críticos, que, face ao inegável acento reflexivo de seu poetar, bem poderiam deturpar-lhe o sentido. A propósito, observa G. R. Lind que alguém como Fernando Pessoa, que “... tinha de actuar dentro de um ambiente para o qual a riqueza sentimental e
a arte da improvisação constituíam índice da categoria de um poeta, devia
necessàriamente sentir-se obrigado a justificar o seu intelectualismo e a de-
fender-se da suspeita de que ele seria sinónimo de frigidez de sentimentos."

A meu ver, no caso da auto-definição que estamos examinando, o equívoco temido por Fernando Pessoa é bem outro, pois "filósofo com faculdades poéticas" é, mais precisamente, uma qualidade de quem produz "poesia filosófica". É a atribuição à sua obra dessa indesejável etiqueta que ele mais teme. ${ }^{3}$ Repare-se que ele faz Ricardo Reis declarar, a certa altura: "A poesia metafísica é ilegítima"”; e isto, explica o heterônimo, porque, conquanto poesia e metafísica sejam produtos intelectuais, a primeira não o é exclusivamente, pois tem o sentimento como elemento primordial. Em outras palavras: "Baseia-se no sentimento, ainda que se exprima pela inteligência. A inteligência deve servir-lhe apenas para interpretar o sentimento."5

Dizendo de outro modo, "poesia filosófica" ou "poesia metafísica" é aquela que resulta de versificação de conceitos e raciocínios e que, portanto, não passa de mera "vestimenta exterior" de idéias previamente concebidas, Logo, não é obra de verdadeiro poeta: é poesia falida.

\footnotetext{
${ }^{2}$ LIND, 1970. p.306.

${ }^{3}$ Sobre esse tipo de poesia, escreve Eduardo Lourenço que se trata de “... um monstro de duas cabeças, de que o único sentido é o de querer dizer que a matéria do poema é constituída de filosofemas ou aparências de filosofemas; ora o que faz dela poesia é justamente a recusa de considerá-los como tais." (LOURENÇO, Le destin Antero de Quental, 1971, p.45-6 apud SEABRA, [s.d], p.408.

${ }^{4}$ PESSOA (REIS), 1995. p.148.

${ }^{5}$ PESSOA (REIS), 1995. p.148-9.
} 
Mais que ninguém, Fernando Pessoa sabe que não é esse o seu caso. Mas, por outro lado, dizer-se “... um poeta estimulado pela filosofia” não significaria que a filosofia se reduz, para ele, a um ponto de referência, externo ao processo formativo, um simples inspirar-se no filosofar alheio?

Vejamos mais duas de suas declarações:

\begin{abstract}
"Chamo insinceras às coisas feitas para pasmar, e às coisas, também - repare nisto que é importante - que não contêm uma fundamental idéia metafísica, isto é, por onde não passa, ainda que como um vento, uma noção da gravidade e do mistério da Vida. Por isso é sério tudo o que escrevi sob os nomes de Caeiro, Reis, Álvaro de Campos. Em qualquer destes pus um profundo conceito de vida, divino em todos três, mas em todos gravemente atento à importância misteriosa de existir."6

“...toda obra de fôlego, pela qual um indivíduo se institui mestre na sua categoria, é, ao mesmo tempo, obra de emoção e de pensamento, contém tanto uma forma de arte como uma fórmula de filosofia. [...] Obra suprema é aquela em que (a par, é certo, da rígida construção que assinala os mestres) pensamento original e emoção própria se reúnem e se fundem ...". 7
\end{abstract}

Esses dois pequenos trechos são eloqüentes o bastante para demonstrar o quanto Fernando Pessoa tinha plena consciência do papel fundamental da filosofia em sua poesia (como em toda poesia digna do nome). E isto quer dizer que o filosófico não é aí um aspecto periférico, tangencial, simples resultante de inspiração extraída deste ou daquele filósofo, desta ou daquela corrente de pensamento, mas, antes, um dom especulativo natural, inato, que se incorpora, desde o início, à intencionalidade formativa, e que, por isso mesmo, fecunda, alimenta e revigora a poesia, contribuindo para levá-la à sua plenitude. Nas suas próprias palavras, trata-se de um dom congênito de, num só ato, captar poesia e filosofia em todas as coisas — “... na terra e no mar, no lago e na mar-

\footnotetext{
${ }^{6}$ PESSOA, 1995. p.55.

${ }^{7}$ PESSOA (REIS), 1995. p.120.
} 
gem do rio [...] na cidade [...] no barulho dos carros nas ruas...", em tudo descobrindo “...um tesouro de significado [...] uma plenitude de sugestão espiritual...”.

A análise que se realizará nos capítulos subsequentes e que terá por base o próprio texto poético de Fernando Pessoa, terá como premissa constante, a convicção de que a filosofia não é, nos versos desse poeta, um simples objeto de discurso, mas uma presença interna, constitutiva, que se irradia dos mais diversos níveis que definem o seu modo de ser. Afinal, na verdadeira poesia, clareza do pensamento e vibração sensível da palavra consubstanciam-se de modo coessencial e inseparável.

Finalizando esse ponto, recordo uma pertinente observação de José Augusto Seabra, que, ponderando sobre a perfeita consubstanciação da filosofia na poesia de Fernando Pessoa, observa que, embora o "germe central” dessa poesia seja “... a oposição e a identidade do Ser e do Não-Ser ...", constituiria um "Erro fatal [...] querer reduzi-la a uma problemática filosófica, no sentido mais estrito do termo: a sua ressonância ontológica, como a sua repercussão metafísica, são consubstanciais à própria pulsação poética, fecundando-a sem a absorver." 9

\subsection{A poesia pessoana e a "crise da razão"}

Um dos caminhos por que passa forçosamente a análise das diretrizes estilística e filosóficas de Fernando Pessoa é a sua inserção no horizonte histórico da chamada "crise da razão", ou "crise do pensamento", dominante na Europa dos inícios do século XX.

\footnotetext{
${ }^{8}$ PESSOA, 1995. p.36-7.

${ }^{9}$ SEABRA, 1974. p.43.
} 
Naturalmente, ao tomar como fio condutor essa inserção histórica do poeta, não estou a supor, nem que seja este o único fator importante — como se sabe, o poeta viveu, de 1896 a 1905 (portanto, dos oito aos dezessete anos), na cidade de Durban na África do Sul, tendo sido decisiva para a sua atividade poética a formação britânica (escolar, artística, cultural) ali recebida ${ }^{10}$ - nem que exista, em qualquer dos casos alguma dependência direta ou derivação mecânica entre os dois termos, ou seja, entre a poesia e o contexto histórico-cultural em que nasce. Como assinala Bakhtin,

\begin{abstract}
“As novas formas de visão artística são preparadas lentamente, pelos séculos; uma época cria apenas as condições ideais para o amadurecimento definitivo e a realização de uma nova forma. [...] Não se pode, evidentemente, separar a poética das análises histórico-sociais assim como não se pode dissolvê-la nestas." 11
\end{abstract}

E isto é verdadeiro não só por tratar-se aqui especificamente da obra de Fernando Pessoa, poeta maior, que não poderia ser situado em dependência ou derivação direta de qualquer circunstância ou contexto de pensamento, mas fundamentalmente porque, toda verdadeira poesia nunca se reduz a simples mimesis ou reflexo de valores preexistentes, mas é, antes, um fato essencialmente hermenêutico e ontológico, no sentido de que seus produtos, resultando de uma interpretação que o artista faz das realidades com que convive (concretas e espirituais), oferecem-se como um valor novo, um acrescentamento da realidade, algo que antes não era e que doravante passa a existir, como uma nova luz lançada sobre o já existente.

\footnotetext{
10 Sobre a educação escolar, artística, cultural de Fernando Pessoa, bem como sobre a influência da cultura inglesa na sua formação, cf. o minucioso estudo: SEVERINO, Alexandrino E. Fernando Pessoa na África do Sul, 1969-70. (v. I e II).

${ }^{11}$ BAKHTIN, 1997. p.37.
} 
A designação "crise da razão", como foi visto no Capítulo 2, diz respeito àquele momento histórico de transição conflituosa, em que toda a cultura ocidental, descrente das totalizações e sistematizações construídas pelo racionalismo filosófico, parte para a exploração das sendas diversas do relativismo, pondo em xeque os valores assentados pela tradição da cultura ocidental.

Em momentos como este, os questionamentos levantados contra o modelo filosófico anterior ainda se apoiam sobre o mesmo solo epistemológico que estão a negar, daí resultando o caráter cambiante e incerto das suas proposições e manifestações. Atente-se, em especial, ao fato de que o relativismo nascente, conquanto investindo duramente contra o saber absoluto, definitivo, imutável, preconizado pelo hegelianismo, o mantém acriticamente na base de sua reflexão, daí concluindo que os saberes particulares, sendo pessoais e históricos, só podem ser esferas de erro e engano.

É, pois, no interior desse horizonte epistemológico de incerteza e descrença, que tem lugar a enunciação pessoana dos princípios diretivos do sensacionismo, a invenção dos heterônimos e, é claro, as expressões diversas do seu misticismo, elementos centrais de sua investida contra a hegemonia do racionalismo metafísico hegeliano, questionando seus pressupostos totalizantes e pondo em xeque a visão de mundo que neles se ancora.

\subsubsection{O sensacionismo}

Sobre o movimento literário sensacionista, Fernando Pessoa escreve, em manuscrito datado provavelmente de 1916: 
sário Verde. Fundou-o Alberto Caeiro, o mestre glorioso [...]. Tornou-o, logicamente, neoclássico o Dr. Ricardo Reis. Moderniza-o, paroxiza-o - verdade que descrendo-o (?) e desvirtuando-o - o estranho e intenso poeta que é Álvaro de Campos. Estes quatro - estes três nomes são todo o movimento. Mas estes três nomes valem toda uma época literária." 12

A justificativa é oferecida em um outro manuscrito ${ }^{13}$, da mesma data provável, onde é colocada em primeiro plano a necessidade de um imediato resgate da pureza sensorial, supostamente caraterística do paganismo greco-romano (no qual nada de estranho se interpunha entre a sensação e o seu objeto, nada que não pertencesse ao próprio ato de sentir), e que teria se desvirtuado devido à espiritualização crescente desencadeada pelos ensinamentos do cristianismo:

\begin{abstract}
"Passada pelas almas a longa doença chamada cristianismo, [...] a clareza da sensação perturbou-se. A presença no pensamento das idéias de espírito, de Deus, de outra vida, concebidas como o eram, levaram a uma decomposição da Realidade, qual os gregos a haviam concebido. Entre a sensação e o objeto dela [...] intercalara-se todo um mundo de noções espirituais que desvirtuava a visão direta e lúcida das cousas." 14
\end{abstract}

Não é difícil perceber, já por esse pequeno trecho, que Fernando Pessoa se inspira em difundidos pressupostos setecentistas, deles oferecendo uma releitura pessoal. Às idéias winckelmannianas sobre a superioridade da arte grega (por sua harmonia e euritmia) ${ }^{15}$ e à necessidade de se imitá-la, conjuga ele o argumento, defendido por

12 PESSOA, 1995. p.427.

${ }^{13}$ Cf. PESSOA, 1995. p.424-6.

${ }^{14}$ PESSOA, 1995. p.424.

${ }^{15}$ A propósito, escreve Lind: "Não é de passar por cima o facto de o ideal grego de Pessoa ter um carácter apolíneo, sendo para ele a essência duma ordem universal exemplar e sã, tal como o concebera Winckelmann. Todos os traços dionisíacos, descobertos por Nietzsche na cultura helénica, são propositadamente descartados por Pessoa, para não prejudicar a sua idealização dessa cultura. A Grécia de Pessoa torna-se assim a personificação abstracta de certas regras cuja vivificação beneficiará a arte moderna. Donde serem Ricardo Reis e Alberto Caeiro poetas apolíneos: Álvaro de Campos, o dionisíaco de entre os heterónimos, é cuidadosamente apartado por Pessoa do neoclassicismo.” (LIND, 1970. p.101-2). 
Hegel na "Fenomenologia do Espírito", de que o equilíbrio de matéria e espírito, tido como característico da arte grega, ter-se-ia rompido com o advento do cristianismo. Segundo a explicação hegeliana, ao revelar-se Deus como espírito e apresentar-se Cristo como imagem da mediação entre o divino e o humano, entre o espiritual e o material, ter-se-ia suprimido a imediatez originária da manifestação divina no sensível, corrompendo-se o estado de perfeita compenetração de interioridade e exterioridade representado na arte da Grécia clássica. A união do humano com o divino já não se representaria em si, imediatamente, mas como movimento de negação da divindade no homem e de elevação a Deus, ao Espírito absoluto - o que estaria implícito na paixão, morte e ressurreição de Cristo.

Em resumo: partindo de uma visão idealizada da Antigüidade, como época supostamente caracterizada pelo estado ideal de pureza e objetividade das sensações, postula Fernando Pessoa que a religião cristã, pregando a liberação do elemento espiritual em relação à materialidade, teria causado um desequilíbrio fatal, sendo missão do sensacionismo resgatar a harmonia perdida.

Note-se que todo o embaraço consiste no seguinte: embora os gregos também tivessem suas crenças e seus deuses, concebiam-nos como uma espécie de prolongamento do humano, enquanto que, sob a ótica introduzida pelo cristianismo, o divino, o espiritual, passa a ser concebido por oposição ao humano, ao terreno e material, acarretando uma dicotomia inconciliável e uma ruptura do equilíbrio originário. Prossegue ele:

\footnotetext{
"Ora, uma alma que encara as cousas como tal conceito no espírito, não as pode encarar diretamente, muito embora queira ter essa preocupação. A noção de alma, concebida como diferente do corpo e superior a ele, começa por tornar menos importante ao espírito as cousas. A noção de Deus substituía-se ao conceito do conjunto das cousas, a que se chamava a Natureza. A noção
} 
do sobrenatural convidava a uma descrença na utilidade, porque na estabilidade, do concreto. Esta nova noção do milagre levava ao desprezo, quando não à indiferença, pela possível existência das leis naturais."

As diretrizes finalmente propostas para a execução desse projeto de recuperação do estado de pureza e equilíbrio da percepção culminam num total privilégio da sensação, como base exclusiva do conhecimento: "Todo o objeto é uma sensação nossa"17; "A única realidade da vida é a sensação"18. Esse sensorialismo, logicamente, abrange a produção da arte: “A única realidade da arte é a consciência da sensação [...]. Em arte há apenas sensações e nossa consciência delas."19

Mas, atenção, todavia: a sensação que o sensacionismo proclama como a matéria da arte não é a sensação em estado original, a qual não passa de mera "emoção sem sentido”. Para aceder ao domínio da arte, tornando-se “... emoção artística, ou susceptível de se tornar artística ...", ela tem de ser racionalizada, intelectualizada, idealizada, trabalhada artisticamente. ${ }^{20}$

Isto nos leva ao princípio programático geral do sensacionismo, o qual tem na própria heteronímia a sua expressão mais bem conseguida: para alcançar a plenitude da expressão, o poeta deve buscar a superação da expressão individual em prol da

\footnotetext{
${ }^{16}$ PESSOA, 1995. p.424-5.

${ }^{17}$ PESSOA, 1995. p.426.

${ }^{18}$ PESSOA, 1995. p.431.

${ }^{19}$ PESSOA, 1995. p.431.

${ }^{20}$ Cf. PESSOA, 1995. p.432 e 448.
} 
expressão sintética, universal, cosmopolita ${ }^{21}$, ou seja, deve deixar de ser um "sujeito artístico" unitário, fechado em contornos definidos, com um determinado modo de sentir, e multiplicar-se, pluripersonalizar-se, quer dizer, viver dentro de si uma pluralidade indefinida de outros "eus" ou "sujeitos artísticos", representativos de outros modos de sentir, de modo a “... evocar — como um halo em torno de uma apresentação definida central — o maior número possível de outras sensações". 22 "Sê plural como o universo" ${ }^{23}$, eis a fórmula que resume esse primeiro princípio programático.

O segundo princípio, de claro matiz positivista, liga-se à poética do "Interseccionismo” - que, segundo Fernando Pessoa, é “... o sensacionismo que toma consciência do fato de que toda sensação é realmente várias sensações misturadas"24 — preconizando, a partir daí, a necessidade de uma decomposição analítica de todos os aspectos que se entrecruzam e se misturam dentro da mente, durante o processo perceptivo e que compõem o que ele chama de "sensação cúbica” dos objetos:

21 Nesse sentido, o sensacionismo dispõe-se a acolher todas as correntes artísticas (mas sem aceitar nenhuma em particular). Por exemplo, aceita, do Classicismo, a construção e a preocupação intelectual, mas recusa a uniformidade de estilo, a expressão simplificada, a preocupação de uma visão nítida do mundo exterior, a tentativa de eliminar o temperamento do artista; do Romantismo, aceita “... a preocupação pictural, a sensibilidade simpatética, sintética perante as cousas”, mas recusa a teoria básica do "momento de inspiração", segundo a qual a obra de arte se produziria como que "... por um jato ...."; do Simbolismo, aceita “... a preocupação musical, a sensibilidade analítica [...] a análise profunda dos estados de alma... ", mas recusa “... a exclusiva preocupação do vago, a exclusiva atitude lírica, e, sobretudo, a subordinação da inteligência à emoção..." (PESSOA, 1995. p.443).

22 PESSOA, 1995. p.432.

${ }^{23}$ PESSOA, 1995. p.81.

24 PESSOA, 1995. p.442. Note-se que o entusiasmo de Pessoa com o Interseccionismo é passageiro. A respeito, é digna de nota a seguinte passagem, escrita em 21.11.1914: "Hoje, ao tomar a decisão de ser $\mathrm{Eu}$, de viver à altura do meu mister, e, por isso, de desprezar a idéia do reclame, e plebéia sociabilização de mim, do Interseccionismo [...] O último rasto de influência dos outros no meu caráter cessou com isto. Reconheci - ao sentir que podia e ia dominar o desejo intenso e infantil de 'lançar o Interseccionismo' — a tranqüila posse de mim. Um raio hoje deslumbrou-se de lucidez. Nasci.” (PESSOA, 1995. p.42). 
“... a sensação do objeto exterior como objeto; a sensação do objeto exterior como sensação; as idéias objetivas associadas a esta sensação [...]; o temperamento e a atitude mental fundamentalmente individual do observador; a consciência abstrata por trás desse temperamento individual. ${ }^{25}$

Essa decomposição analítica, embora inspirada nos procedimentos da pintura cubista/futurista (particularmente do cubismo analítico), não tem em vista os objetos, mas as “... nossas sensações das coisas" "26.

Pode-se observar a repercussão dessas idéias no delineamento dos traços distintivos de cada heterônimo - em Alberto Caeiro, a meta objetivista de colher "a sensação do objeto exterior como objeto"; em Álvaro de Campos, a meta de colher "a sensação do objeto exterior como sensação"; em Ricardo Reis, a intelectualização da sensação e a atenção às idéias objetivas a ela associadas - bem como nos poemas de Fernando Pessoa ortônimo, notadamente naqueles que compõem a série intitulada "Cancioneiro", onde o cultivo da já citada "ideação complexa", indica o anseio de transcender a unilateralidade dos enfoques representados por Caeiro, Campos e Reis e lograr o que se poderia chamar de uma perfeita comunhão do subjetivo com o objetivo, do espiritual com o sensível e material.

Mas há ainda um terceiro princípio poético — o princípio da "Construção". ${ }^{27}$ Sobre este princípio, chamo especial atenção, pois tem um papel decisivo no sentido de valorizar o planejamento consciente que preside o processo propriamente formativo da arte, contrabalançando, assim, a preocupação com a sua base sensorialista.

${ }^{25}$ PESSOA, 1995. p.442.

${ }^{26}$ PESSOA, 1995. p.431. (Grifo do autor).

${ }^{27}$ Devido à atenção de Pessoa a esse princípio, Roman Jakobson o exalta como um dos mais notáveis poetas da "estruturação". (JAKOBSON, 1978. p.121). 
“Toda a arte é criação, e está portanto subordinada ao princípio fundamental de toda a criação: criar um todo objetivo ...”, orgânico, “... em que haja a precisa harmonia entre o todo e as partes componentes, não harmonia feita e exterior, mas harmonia interna e orgânica." ${ }^{28}$ Dentre outras coisas, isto quer dizer que, para entrarem na arte, as sensações devem ser idealizadas, trabalhadas artisticamente, de modo a se integrarem às outras partes que compõem a obra, daí resultando a "construção" de um significado novo, um novo ser, uma nova realidade. O princípio da "Construção", que Pessoa conceitua como “... o maior princípio dos gregos" e primeira regra fundamental da arte, é explicitamente extraído da "Poética", de Aristóteles, remetendo a conhecidas idéias aristotélicas, sobre "O mito como ser vivente"29: "Um poema é um animal, [...] um ente vivo" 30 , e deve, portanto, “... ter a maior semelhança possível com um ser organizado, porque esta é a condição da vitalidade". ${ }^{31}$

Por outro lado, é preciso salientar que, malgrado esse privilégio consignado à sensação, subsistem na prosa e na poesia iniciais de Fernando Pessoa, notórios resíduos de pensamento hegeliano.

A repercussão poética desse hegelianismo inicial (que sem dúvida se deve ao seu estreito contato com Teixeira de Pascoaes, nos tempos em que atuou como ensaísta na revista “A Águia”, da Renascença Portuguesa) se faz notar, por exemplo, na “ideação complexa”, que rege boa parte do Cancioneiro e que será comentada no capí-

\footnotetext{
${ }^{28}$ PESSOA, 1995. p.434.

${ }^{29}$ Poética 1450b 22.

${ }^{30}$ PESSOA, 1995. p.434.

${ }^{31}$ PESSOA, 1995. p.432.
} 
tulo referente à poesia ortônima. ${ }^{32}$ Todavia, embora à primeira vista se tenha a impressão de uma fidelidade significativa ao modelo hegeliano ${ }^{33}$, isto não ocorre verdadeiramente. Como será discutido mais à frente, a síntese dialética está ausente tanto na construção dos oxímoros, quanto no que toca ao sentido global da poesia de Fernando

Pessoa.

\subsubsection{A heteronímia}

Com mais freqüência, a heteronímia tem recebido explicações psicologistas, psicanalíticas, biográficas, que a descrevem, ora como um remédio ou terapia para a

\footnotetext{
${ }^{32}$ No ensaio sobre a nova poesia portuguesa, a filosofia de Hegel é qualificada como “... um exemplo único e eterno..." do "transcendentalismo panteísta" subjacente a essa poesia. (Cf. PESSOA, 1995. p.393). Nesse mesmo ensaio, falando sobre o movimento triádico da dialética de Hegel, Pessoa o reconhece como característico não apenas do pensamento substancial do citado filósofo (“... o ser em si (Sein) se torna outro-ser (Dasein) e volta a si (für sich Sein)"), mas como uma lei geral, diversamente encontrável na história do pensamento: já na Antigüidade, no “... o triplo movimento — tese, antítese, síntese da dialética de Platão..."; no movimento triplo da ode triunfal, pindárica — "strofe, antístrofe, epodo"; na lei que, na doutrina cristã da Santíssima Trindade, “... representa Deus como sendo aquele de quem tudo procede, como Pai, por quem tudo existe, como Filho, e para quem tudo existe, como Espírito Santo". (PESSOA, 1995. p.289). De passagem, cumpre assinalar que, por poesia nova, Pessoa está a designar, não “... poesia de jovens - a palavra 'novo' opõe-se a 'antigo' que não a 'velho'-, mas poesia que representa novidade, quer em seu íntimo conteúdo, quer em sua expressão e os modos dela." (PESSOA, 1973. p.344). E essa novidade consiste, no caso, em que a poesia exibe “... uma religiosidade nova, [...] completamente e absorventemente metafísica e religiosa" (PESSOA, 1995. p. 386-7).
}

33 Note-se que, ao traçar uma rápida história das produções artísticas, Pessoa a refere à história da sociedade em geral, daí concluindo que a arte constitui, em cada momento da história universal, a expressão sensível da consciência histórica de um povo, e que, assim sendo, as correntes literárias são, em sua essência, “... a expressão pela literatura de uma comum noção do mundo, da arte e da vida..." (de uma Weltanschauung, diria Hegel). Compreender essas correntes literárias implica, pois, compreender a filosofia que a elas subjaz. (PESSOA, 1995. p.380). Note-se que, segundo esse modelo explicativo, os momentos singulares da produção poética são referidos a uma estrutura mais ampla, que os engloba (primeiro o movimento evolutivo da poesia européia, depois o movimento evolutivo da história universal), definindo-se o seu sentido pela suposição do seu nexo com o todo. Com base nesse parâmetro explicativo, o caráter da nova poesia é deduzido a priori, como resultado necessário do movimento evolutivo da poesia européia, que “... parte do espiritualismo e avança até ao panteísmo, e daí, inevitavelmente, subirá para a complexidade máxima do transcendentalismo, até chegar ao limite, o transcendentalismo panteísta”. (PESSOA, 1995. p.395). 
"mórbida inquietação" de que padeceria o homem Fernando Pessoa, ora como uma espécie de “... refúgio para o delírio que o leva à despersonalização...”34.

O próprio Fernando Pessoa tem certo grau de responsabilidade sobre esse estado de coisas, na medida em que conhecidas passagens de sua prosa endossam esse tipo de explicação.

Com efeito, são muitos os trechos de suas cartas, anotações pessoais e outros escritos, que relacionam a gênese dos heterônimos à natureza do seu psiquismo. Alguns a descrevem como um processo instintivo, inconsciente, alheio à sua vontade “... parece que fui eu, criador de tudo, o menos que ali houve. Parece que tudo se passou independentemente de mim. E parece que assim ainda se passa",35 —, outros chegam a sugerir um tipo de possessão mediúnica (a "Ode triunfal", de Campos, por exemplo, teria sido elaborada "Num jato, e à máquina de escrever, sem interrupção nem emenda ...$\left.{ }^{36}\right)$ —, e há, ainda, os trechos que atribuem a criação dos heterônimos a distúrbios psíquicos, manifestados já em sua infância:

"Tive sempre, desde criança, a necessidade de aumentar o mundo com personalidades fictícias, sonhos meus rigorosamente construídos, visionados com clareza fotográfica, compreendidos por dentro das suas almas. [...] Além disso, esta tendência não passou com a infância, desenvolveu-se na adolescência, radicou-se com o crescimento dela, tornou-se finalmente a forma natural do meu espírito. Hoje já não tenho personalidade: quanto em mim haja de humano, eu dividi entre os autores vários de cuja obra tenho sido o executor. Sou hoje o ponto de reunião de uma pequena humanidade só minha. [...] Médium, assim, de mim mesmo todavia subsisto" ${ }^{37}$;

\footnotetext{
${ }^{34}$ ALCÂNTARA, 1985. p.35.

${ }^{35}$ PESSOA, 1995. p.97.

${ }^{36}$ PESSOA, 1995. p.95.

${ }^{37}$ PESSOA, 1995. p.92.
} 
"A origem dos meus heterônimos é o fundo traço de histeria que existe em mim. Não sei se sou simplesmente histérico, se sou, mais propriamente, um histero-neurastênico. Tendo para esta segunda hipótese, porque há em mim fenômenos de abulia que a histeria, propriamente dita, não enquadra no registo dos seus sintomas. [...] Estes fenômenos — felizmente para mim e para os outros - mentalizaram-se em mim; quero dizer, não se manifestam na minha vida prática, exterior e de contato com outros; fazem explosão para dentro e vivo-os eu a sós comigo. Se eu fosse mulher [...] cada poema de Álvaro de Campos (o mais histericamente histérico de mim) seria um alarme para a vizinhança. Mas sou homem - e nos homens a histeria assume principalmente aspectos mentais; assim tudo acaba em silêncio e poesia..."38;

"É, não sei se um privilégio se uma doença, a constituição mental que a produz. O certo é que o autor dessas linhas — não sei bem se o autor destes livros - nunca teve uma só personalidade, nem pensou nunca, nem sentiu, senão dramaticamente, isto é, numa pessoa, ou personalidade, suposta, que mais propriamente do que ele próprio pudesse ter esses sentimentos. [...] A cada personalidade mais demorada, que o autor destes livros conseguiu viver dentro de si, ele deu uma índole expressiva, e fez dessa personalidade um autor, com um livro, ou livros, com as idéias, as emoções, e a arte dos quais, ele o autor real (ou porventura aparente, porque não sabemos o que seja a realidade), nada tem, salvo o ter sido, no escrevê-las, o médium de figuras que ele próprio criou. [...] $\mathrm{O}$ autor humano destes livros não conhece em si próprio personalidade nenhuma. Quando acaso sente uma personalidade emergir dentro de si, cedo vê que é um ente diferente do que ele é, embora parecido; filho mental, talvez, e com qualidades herdadas, mas as diferenças de ser outrem. [...] Algumas teorias, que o autor presentemente tem, foram-lhe inspiradas por uma ou outra destas personalidades que, um momento, uma hora, uns tempos, passaram consubstancialmente pela sua própria personalidade, se é que ela existe". 39

Mas, por outro lado, não faltam passagens em que o mesmo Fernando Pessoa manifesta a sua total discordância em relação a qualquer tipo de psicologismo literário - bem expressiva, nesse sentido, é, por exemplo, a já citada carta, em que ele adverte João Gaspar Simões quanto ao seu dever, enquanto crítico literário, de ater-se à obra e não ao psiquismo do autor - e enfatiza o caráter planejado, consciente, da heteronímia. $^{40}$

\footnotetext{
${ }^{38}$ PESSOA, 1995. p.95.

${ }^{39}$ PESSOA, 1995. p.82.
}

${ }^{40}$ Enfatizando esse caráter planejado da heteronímia, Georg Rudolf Lind refere o nascimento de Ricardo Reis a um programa poético pré-existente, datado de janeiro de 1914, e anterior, portanto, ao surgimento de "O guardador de rebanhos", em 8 de março de 1914, o qual, segundo Pessoa, revestiu-se de um caráter intempestivo. 
As personalidades heterônimas, explica Pessoa em um desses escritos, são construções literárias, de caráter ficcional, não sendo, portanto, adequado considerá-las como “... desdobramentos de personalidade...”, e sim como “... invenções de personalidades diferentes...". ${ }^{41}$ Em outro lugar, discorrendo sobre seu projeto “... de lançar pseudonimamente a obra Caeiro-Reis-Campos", escreve: "Isso é toda uma literatura que eu criei e vivi, que é sincera, porque é sentida [...]. Isso é sentido na pessoa de outro; e escrito dramaticamente, mas é sincero [...] como é sincero o que diz o Rei Lear, que não é Shakespeare, mas uma criação dele. "42 Assim sendo, do mesmo modo que não é legítimo buscar na personagem Hamlet “... uma definição dos sentimentos e dos pensamentos de Shakespeare ...”, não é legítimo buscar em qualquer dos heterônimos “... idéias ou sentimentos meus, pois muitos deles exprimem idéias que não aceito, sentimentos que nunca tive. Há simplesmente que os ler como estão, que é aliás como se deve ler" ${ }^{\text {43 }}$. Em carta endereçada a Adolfo Casais Monteiro: “... pus no Caeiro todo o meu poder de despersonalização dramática, pus em Ricardo Reis toda a minha disciplina mental, vestida da música que lhe é própria, pus em Álvaro de Campos toda a emoção que não dou nem a mim nem à vida". ${ }^{44}$ É útil lembrar, ainda o comentário de Pessoa, indicativo de sua consciência do distanciamento da sua filosofia pessoal relativamente à presente na obra heterônima: “... o problema metafísico meu não existe, porque não pode, nem tem que existir adentro das capas destes meus livros de outros". 45

\footnotetext{
${ }^{41}$ PESSOA, 1995. p.87.

${ }^{42}$ PESSOA, 1995. p.55.

${ }^{43}$ PESSOA, 1995. p.87.

${ }^{44}$ PESSOA, 1995. p.94.

${ }^{45}$ PESSOA, 1995. p.84.
} 
Além desses depoimentos de Fernando Pessoa, também delimitam o alcance da hermenêutica psicanalítica de sua obra as evidentes correspondências e consonâncias que de certo vinculam a criação dos heterônimos ao seu contexto histórico-cultural.

Sem chegar ao extremo, igualmente equivocado, de qualificar a heteronímia como decorrência de uma alienação pessoana "... no caos do absurdo" ${ }^{46}$, é proveitoso relacioná-la, por exemplo, com os procedimentos despersonalizantes em voga na literatura de início do século XX, ou, mais de perto ainda, com as estratégias pluripersonalizantes preconizadas pelo próprio programa sensacionista por ele criado. Esse sentimento de fragmentação do eu tem um exemplo na própria multiplicação heteronímica. Repare-se, a propósito, esta confissão de Fernando Pessoa: “Hoje já não tenho personalidade: quanto em mim haja de humano, eu o dividi entre os autores vários de cuja obra tenho sido o executor". ${ }^{47}$

A pluripersonalização, o devir-outro, trazendo para o espaço da criação poética outros "autores" ou "sujeitos artísticos", representativos de outros modos de pensar, sentir e poetar, implica uma não coincidência do eu poético consigo mesmo. É, nesse sentido, uma estratégia despersonalizante, um modo de superar os limites do "sujeito artístico" tradicional, exibindo, portanto, uma significativa consonância com a já citada problemática da "crise do sujeito".

A propósito dessa sintonia, penso, por exemplo, em Baudelaire — em especial, no privilégio que este consigna ao poeta, de poder, “... à sua vontade, ser ele pró-

\footnotetext{
${ }^{46}$ SACRAMENTO, 1970. p.95.

${ }^{47}$ PESSOA, 1995. p.92.
} 
prio e outro" 48 , ou seja, de poder despersonalizar-se e tomar de empréstimo atitudes alheias, inclusive para consigo, tornando-se assim um objeto para si mesmo. Ou, ainda, na intuição inicial de Rimbaud, apontando o autor como uma espécie de "demiurgo", um intermediário de instâncias desconhecidas que conduzem a feitura de sua obra ${ }^{49}$ “"Eu' é um outro. [...] Estou presente à germinação de meu próprio pensamento, observo-o, ouço-o. [...] É errado dizer Eu penso; dever-se-ia dizer estou sendo pensado.",50

Atento a essa consonância da heteronímia com o seu tempo, escreve Benedito Nunes:

\begin{abstract}
"Da simples expressão da subjetividade, em que o Eu se colocava em primeiro plano, tornou-se a lírica moderna, em virtude dessa crise, a expressão, primeiro, de um rompimento do poeta com o mundo social e exterior e, depois, do abandono desse mesmo Eu, que já em Baudelaire e Rimbaud deixava de apresentar-se como centro fixo e biográfico, pessoal e unitário. [...] A individualidade propriamente dita tornar-se-ia insignificante, aparecendo, em lugar dela, como em Baudelaire, um sujeito poético, universal, desincorporado da vida imediata do poeta. É este sujeito que fala com uma voz diferente, de ressonância cósmica: 'J'ai plus de souvenirs que si j'avais mil ans' ou 'Je suis le roi d'un pays pluvieux'." 51
\end{abstract}

Obviamente, desde que bem entendidos, os argumentos acima não comprometem a singularidade dessa escolha programática de Fernando Pessoa, nem diminuem a sua relevância. Simplesmente salientam os vínculos contextuais, trazendo à luz a sintonia dessa multiplicação em numerosos "autores" com uma certa convicção cultural

${ }^{48}$ BAUDELAIRE apud NUNES, 1969. p.231. (A ortografia foi atualizada).

49 Observe-se que, desse prisma, resulta também debilitada a noção tradicional de "obra" como unidade fechada em torno de um significado único: contra tal noção, o poema se proporia como um espaço "multidimensional" e "intertextual", constituído pela absorção e transformação de vários outros textos, como que a evocar a idéia pós-moderna de que todo texto é um "palimpsesto", um escrito sob o qual se pode sempre descobrir escritos anteriores, nenhum deles original.

${ }^{50}$ RIMBAUD apud FISCHER, 1983. p.106.

${ }^{51}$ NUNES, 1969. p.230-1. (A ortografia foi atualizada). 
assimilada e difundida à sua época e inspiradora de procedimentos afins em outras poéticas, todas elas empenhadas num vivo questionamento, não apenas do conceito de "autor", mas de qualquer centro significante fixo e privilegiado.

Fernando Pessoa reage à sua maneira, evidentemente, e talvez até dê vazão a alguma inclinação inata, mas o fato é que não deixa de concretizar, nesse seu gesto, uma recusa veemente, que não é apenas sua, mas de vários outros poetas de sua geração, do "sujeito artístico" tradicional, unitário, fechado em contornos definidos, em prol de um novo conceito de autor, como intermediário de instâncias desconhecidas e portanto, como um elemento dentre outros na feitura da obra.

Há mais um outro modo de entender a criação dos heterônimos à luz da sua inserção na crise do racionalismo metafísico. E mais uma vez é preciso questionar suposições bastante difundidas. Refiro-me à idéia de que a multiplicação em vários autores teria um escopo totalizante, quer dizer, representaria uma tentativa pessoana de superar a parcialidade das mundivivências individuais e alcançar um saber mais abrangente.

$\mathrm{O}$ argumento que sustenta essa tese pode ser paradigmaticamente resumido da seguinte forma: "Como cada pessoa tem apenas sua visão particular das coisas, o poeta genialmente se multiplicou em figuras, cada uma com um modo peculiar de apreender o mundo. Com isso, conseguiu ter uma compreensão mais global da realidade. ${ }^{, 52}$

52 GOMES, 1994. p.7-8. 
Ora, cabe aqui interpor que, se por um lado Fernando Pessoa tem anseio de totalidade, de alcançar o absoluto, a verdade definitiva, por outro, ele é um poeta antiracionalista, desconfiado de qualquer pretensão unificadora - um poeta que não cansa de afirmar que "... a essência do universo é a contradição"53; que "A suprema verdade que se pode dizer de uma coisa é que ela é e não é ao mesmo tempo"; que “... uma afirmação é tanto mais verdadeira quanto maior contradição envolve" ${ }^{\text {"54 }}$.

Assim sendo, seria mesmo plausível ver a multiplicação em heterônimos como uma estratégia peculiar, para conseguir uma compreensão global da realidade?

A tentativa de responder a esta pergunta é o fio condutor da investigação que me proponho a realizar, o que supõe, naturalmente, o entendimento da heteronímia como forma de metalinguagem poética e, ao mesmo tempo, o reconhecimento da dimensão ontológica dessa consciência eminentemente construtiva.

Dos dois modos, continuamos imersos no mesmo horizonte cultural e epistemológico de "deposição" do sujeito.

De um lado, a criação de uma constelação de autores, compondo uma "coterie inexistente”, sinaliza o direcionamento do discurso poético para as suas próprias razões intrínsecas, ou seja, é forma de metalinguagem: mais que a poetização do ato de fazer poesia, trata-se da criação de uma verdadeira galeria de "poetas-textos", cujo significado é auto-reflexivo, imanente ao seu próprio modo de estruturar-se.

\footnotetext{
53 PESSOA, 1995. p.393.

54 PESSOA, 1995. p.393.
} 
Do outro, o conceito pareysoniano de modo de formar nos esclarece que essa preocupação "estrutural”, "metalinguística", de Fernando Pessoa, longe de acarretar uma debilitação ontológica da sua poética, é a sede e o esteio desse seu alcance (é no próprio modo como organiza o seu discurso poético que se concretiza toda a sua maneira de sentir, existir, pensar e posicionar-se diante do mundo).

Assim sendo, se por um lado, a constelação de poetas, por ele inventada, tem como eixo a reflexão sobre o próprio ato de fazer poesia, por outro, isto não quer dizer que seu sentido seja de negação do alcance ontológico da heteronímia. Pelo contrário, desde que se entenda o conceito de estilo na acepção pareysoniana de modo de formar — o qual é, de per si, "conteúdo expresso" — não há como deixar de acolher a afirmação de que a heteronímia é, de per si, “... um diálogo com o ser, que na linguagem se consuma e que, através da linguagem, remete àquela existência em si, àquele algo que há". 55

Como bem observa Fernando Segolin, certamente “... Pessoa poderia ter-se limitado a multiplicar as indagações e as possíveis respostas num espaço textual sempre o mesmo." 56 Todavia, não o fez, e por uma razão muito importante: se assim fizesse, “... o signo poético permaneceria para sempre o alheio às questões que procuraria exprimir." ${ }^{, 57}$ Pluralizando-se textualmente, em conformidade com os múltiplos ângulos de visão do problema do ser e da existência, a sua linguagem recusa o papel de mero veículo comunicativo das idéias apresentadas, “... para ser, acima de tudo, diferentes

\footnotetext{
${ }^{55}$ NUNES, 1969. p.234.

${ }^{56}$ SEGOLIN, 1992. p.26.

${ }^{57}$ SEGOLIN, 1992. p.26.
} 
formas de experimentar/ questionar sua capacidade representativa desse mesmo ser e dessa mesma existência.",58

As considerações acima obrigam-me a insistir, mais uma vez, sobre uma questão primordial, que é o fato de que a preeminência construtiva em Fernando Pessoa não constitui um traço formalista de seu poetar, mas, pelo contrário, é o pilar de sustentação do seu alcance ontológico. Em outras palavras, o voltar-se da sua poesia para o ato mesmo de fazer poesia não implica que seu discurso se esqueça do mundo e do homem. O discurso primeiro de toda autêntica poesia é aquele que se veicula através do seu modo de formar, quer dizer, através da sua disposição formal. Assim, o ato de voltar-se para a própria forma não é uma simples operação técnico-programática, mas uma verdadeira investigação ontológica, um verdadeiro e próprio "diálogo com o ser" — não apenas porque o modo de formar é sempre pessoal, e, como a pessoa, está em relação com o ser, mas sobretudo porque, nesse plano, tem lugar a transformação da matéria e dos conteúdos espirituais, dando lugar a um significado original, intraduzível e inseparável do modo como se constrói, enfim, fazendo nascer um novo ente, um novo ser.

Nesse sentido, faz notar o próprio Fernando Pessoa: cada poema é um todo objetivo, dotado de harmonia,“... não harmonia feita e exterior, mas harmonia interna e orgânica. Um poema é um animal, disse Aristóteles; e assim é. Um poema é um ente vivo". 59

À luz dessas convicções, passo, nos capítulos seguintes, a investigar os modos diversos do ceticismo pessoano, não apenas nos seus temas e assuntos, mas, mais

\footnotetext{
${ }^{58}$ SEGOLIN, 1992. p.26-7.

${ }^{59}$ PESSOA, 1995. p.434.
} 
intensivamente, no modo de formar que preside à elaboração do seu discurso poético. Com Luigi Pareyson, entendo que o sentido que daí se irradia é singular e perfeitamente consubstanciado com a sua fisicidade, portanto, só nela pode ser buscado. São, pois, as inflexões estilísticas, tanto ou talvez mais que os enunciados explícitos, que comunicam aquela tensão dubitativa inconciliável, pela qual sua poesia plural se apresenta como metáfora viva da própria irredutibilidade do real e da impossibilidade de se alcançar a verdade última das coisas.

\title{
3.2.3 O misticismo
}

É bem sabida a orientação da poética de Fernando Pessoa para formas diversas de ocultismo, esoterismo e teosofia. Observa Bendito Nunes, que, embora sejam empregados geralmente de modo indistinto, esses termos não significam a mesma coisa:

\begin{abstract}
"Desses termos, o mais genérico é esoterismo, que quer dizer o lado secreto, velado, só a uns poucos transmitido, de verdades que apenas superficial e exteriormente traduzem-se nas crenças religiosas comuns. Trata-se, portanto, de ensinamento reservado, do gênero daqueles a que tinham acesso os adeptos dos antigos Mistérios, dionisíacos, eleusinos e órficos, detentores de uma revelação de ordem superior, que lhes abria a possibilidade de desenvolverem poderes ocultos que, embora inerentes ao homem, seriam desconhecidos e raramente cultivados. $\mathrm{O}$ ocultismo refere-se mais propriamente ao aspecto mágico desses poderes, que propiciariam o controle de várias espécies de forças, entidades e seres, naturais e preternaturais. [...] Teosofia, etimologicamente conhecimento da divindade, por iluminação ou participação mística, tornouse praticamente, desde os fins do século XIX, a denominação de um pretenso sistema, de uma parafilosofia, espécie de síntese enciclopédica de crenças e cultos antigos, extraídos de diferentes contextos religiosos, especialmente do bramanismo e do budismo, sistema que também se apresenta na obra de seus promotores, Annie Besant, Leadbeater e Blavatsky, como super-religião coordenada por uma Sociedade Teosófica." ${ }^{, 00}$
\end{abstract}

${ }^{60}$ NUNES, 1969. p.246-7. (A ortografia foi atualizada). 
Embora seja uma orientação presente em momentos diversos da poesia pessoana, inclusive em algumas odes de Ricardo Reis e em alguns poemas de Álvaro de Campos, é sobretudo na produção ortônima que esse misticismo difuso se faz mais claramente manifesto.

Pode-se notá-lo não apenas em obras explicitamente concebidas segundo esse tipo de simbolismo — como "Mensagem", "Quinto Império" [46] e "À Memória do Presidente-rei Sidónio Pais" [45] — ou de caráter ostensivamente doutrinário e iniciático — como "Iniciação" [137] ${ }^{61}$, "Na sombra do Monte Abiegno" [138] ${ }^{62}$, "Eros e Psique" [182], "No túmulo de Christian Rosencreutz" [198] $]^{63}$-, mas também, aqui e ali (e de modo não univocamente decodificável) em boa parte de seus poemas.

Excetuando-se o caso de "Mensagem" ${ }^{64}$, poema cujo simbolismo esotérico sempre desperta especial atenção dos estudiosos da obra pessoana, as controvérsias hermenêuticas dizem respeito, geralmente, a essa última classe de poemas, onde a possibilidade de múltipla decodificação naturalmente suscita maior diversidade de interpretações.

Um exemplo é o poema que abaixo transcrevo:

${ }^{61}$ Cf. LIND, 1970. p.279-84, onde, na análise desse poema, o crítico procura “... demonstrar como o poeta refunde vários elementos da tradição ocultista em algo novo, ou seja, na obra de arte.” (p.280).

${ }^{62}$ Sobre a estreita correlação entre alguns aspectos desse poema e trechos da prosa pessoana acerca da temática esotérica, cf. LIND, 1970. p.284-7.

${ }^{63}$ Mais próximos da simbologia cristã, os três enigmáticos sonetos que compõem essa obra têm seu conteúdo teosófico dedicado ao fundador do Rosacruz. Segundo explicação de Benedito Nunes, Rosa simboliza a floração do espírito; Cruz, o caminho do sofrimento, que é a chave das transmutações espirituais, de que as transmutações alquímicas constituem o paralelo. (NUNES, 1969. p.251). Sobre o aproveitamento poético da temática esotérica nesse poema, cf. LIND, 1970. p.287-94.

${ }^{64}$ Comento este poema mais à frente, no capítulo dedicado à poesia de Fernando Pessoa ortônimo. 
Neste mundo em que esquecemos

Somos sombras de quem somos,

$\mathrm{E}$ os gestos reais que temos

No outro em que, almas, vivemos,

São aqui esgares e assomos.

Tudo é noturno e confuso

No que entre nós aqui há.

Projeções, fumo difuso

Do lume que brilha ocluso

Ao olhar que a vida dá.

Mas um ou outro, um momento,

Olhando bem, pode ver

$\mathrm{Na}$ sombra e seu movimento

Qual no outro mundo é o intento

Do gesto que o faz viver.

E então encontra o sentido

Do que aqui está a esgarrar,

E volve ao seu corpo ido,

Imaginado e entendido,

A intuição de um olhar.

Sombra do corpo saudosa,

Mentira que sente o laço

Que a liga à maravilhosa

Verdade que a lança, ansiosa,

No chão do tempo e do espaço.

Alguns críticos vêem aqui um “... poema sobre as relações entre existência

terrestre e reino invisível dos espíritos ..."65; outros, “... uma versão ou recriação poética..." da teoria de Platão sobre a dualidade dos mundos ${ }^{66}$. Sobre este poema, assinala Georg Rudolf Lind, baseando-se numa carta de Fernando Pessoa a Casais Monteiro:

"O poeta desvaloriza a existência terrestre do homem, denominado-a de 'sombra', e reconhece o corpo verdadeiro no sósia invisível, o que cada indivíduo possui no reino dos espíritos, i.é o Eu ideal. A vida terrestre aparece-

\footnotetext{
${ }^{65}$ LIND, 1970. p.267.

${ }^{66}$ LINHARES FILHO, 1982. p.29.
} 
lhe, consequentemente, como um desterro, todas as imperfeições do Eu terrestre podem apenas ser compreendidas com referência ao existir de um modelo perfeito no Além. Sòmente o iniciado recebe a intuição desta verdade, embora apenas por curtos momentos. O Eu terrestre (a sombra), assim o descobre o eleito, está ligado com o seu Eu verdadeiro e supernatural por um laço secreto; tende a regressar a ele, porque só nele poderá encontrar esclarecimento acerca dos enigmas da existência terrestre. Comparado ao Eu verdadeiro do reino espiritual, o Eu terrestre revela-se como uma mentira; esta mentira só pode ser dissolvida no momento em que regressa à verdade do Eu ideal. Então torna-se evidente que o mundo superior (a verdade) impusera ao homem, por motivos inexplicáveis, a existência no tempo e no espaço como um estado transitório."

Em favor desse tipo de explicação mística, pode-se dizer que o próprio Platão, assim como alguns de seus mais conhecidos antecessores, por exemplo, Empédocles e os pitagóricos, teriam bebido na fonte de um misticismo esotérico bastante difundido na Antigüidade, a partir do século VI a. C. — o orfismo — seita filosóficoreligiosa que concebia a vida terrena como simples preparação para uma vida mais alta e, além disso, pregava a metempsicose.

Todavia, embora não se possa, por um lado, desconhecer a influência órfica sobre Platão, por outro lado, também não se pode supervalorizá-la, minimizando a sua originalidade quanto à problematização filosófica dessas idéias. De certo, são idéias comuns ao platonismo e a várias seitas filosófico-religiosas: 1) a existência de dois mundos - o sensível e o transcendente — sendo o primeiro confuso e ilusório, mera sombra ou projeção da clareza e perfeição eternamente existente no segundo; 2) a noção de que ocorre um esquecimento desse mundo perfeito e luminoso, pela nossa alma, durante sua existência no plano material, sendo possível, apenas a alguns espíritos privilegiados, reavivar, mediante um conhecimento intuitivo, a recordação da luminosidade transcendente. Mas, paralelamente, é um legado filosófico deixado por Platão, por

${ }^{67}$ LIND, 1970. p.268. 
exemplo, o duplo movimento que caracteriza a dialética entre os dois mundos — ascendente (relacionamento dos fatos sensíveis às suas formas eternas e incorpóreas) e descendente (realização das formas transcendentes no plano sensível).

Passando à análise textual do poema, chamo a atenção, primeiramente, para o uso do verbo esquecer onde seria esperável o verbo viver: no primeiro verso da primeira estrofe, o mundo sensível é referido como "mundo em que esquecemos" (grifo meu). No quarto verso da mesma estrofe, o mundo transcendente é referido como aquele "em que, almas, vivemos" (grifo meu). Isto subentende uma noção axial: no plano físico, não há vida propriamente, nem conhecimento verdadeiro, apenas esquecimento e projeções (sombras) da verdade anterior à encarnação.

Uma outra observação refere-se à repetição do verbo ser, no começo e no final do segundo verso. Note-se que ele é repetido na primeira pessoa do plural e sempre no presente do indicativo, mas o sentido é diferente nos dois casos: o "Somos" inicial é copulativo, opera a ligação do atributo "sombras" ao sujeito "nós" (oculto); enquanto o que aparece no final do verso designa a existência, em sentido absoluto. É fundamental notar que o verso diz sombras de quem somos, e não de quem fomos, o que está de acordo com a tese platônica da contemporaneidade dos dois mundos, e não com a difundida crença religiosa de uma pré-vida da alma.

Nos dois versos seguintes — "E os gestos reais que temos / No outro em que, almas, vivemos", convém notar que o termo "almas" aparece sem conjunção, isolado do restante do verso por duas vírgulas, o que enfatiza a idéia de pureza e imaterialidade das almas no "outro" mundo. Finalizando o comentário sobre esta estrofe, cabe ressaltar a relação cópia-modelo, sugerida nos três últimos versos: os nossos gestos 
físicos são aparências ou imitações distorcidas ("esgares e assomos") dos gestos reais e paradigmáticos do "outro" mundo.

A segunda estrofe salienta a obscuridade das imagens do mundo fenomênico ("noturno e confuso"), por comparação brilho inacessível ("ocluso") do mundo transcendente, do qual não passam de meras "Projeções, fumo difuso".

Na terceira estrofe, chamo a atenção para a consonância das imagens poéticas com a tese platônica de que apenas alguns espíritos podem vislumbrar as "causas inteligíveis" e transcendentes do que é apreendido pelos sentidos. Nesse sentido, observe-se, no primeiro verso, "Mas um ou outro, um momento," a construção inusitada, que destaca entre vírgulas a especificidade e unicidade desse momento de vislumbre do intento transcendente que preside e vivifica os gestos humanos.

A quarta estrofe confirma esse movimento ascendente, de ascese puramente espiritual em direção às causas inteligíveis dos fatos sensíveis. Gradativamente, o poema vai promovendo a negação do conhecimento sensível e deslocando a episteme, o saber da verdade, para o plano extra-fenomênico, o qual detém o verdadeiro ser das coisas e é sede do conhecimento verdadeiro.

A quinta e última estrofe completa, em certa medida, o duplo movimento da dialética platônica: o ascendente (que relaciona os fatos sensíveis às suas essências inteligíveis) e descendente (pelo qual as referidas essências se materializam no plano sensível). Concretiza-se aqui não só o movimento ascendente, pelo qual a "mentira" da nossa existência terrena se liga à "maravilhosa / Verdade" do mundo transcendente, mas também o movimento descendente, pelo qual a verdade supra-sensível se materializa como sombra "ansiosa", lançada "No chão do tempo e do espaço." 
Com base no exposto, penso que o poema em apreço, sem dúvida, pode acolher mais de uma chave interpretativa. Ademais, tanto no caso da chave platônica quanto no da chave mística, não se trata de referências forçadas, abusivas, mas pelo contrário, amplamente respaldadas pelo conhecimento que se tem das leituras filosóficas e místicas do poeta. Note-se que é bem significativo o conhecimento filosófico pessoano, especialmente sobre Platão, cuja doutrina ele comenta e critica com notória desenvoltura, em diversas passagens. ${ }^{68}$ Por outro lado, uma hipótese que, talvez, possa conciliar essas divergências de interpretação, seja a da aproximação com o Neoplatonismo (plotiniano ou renascentista), que, como se sabe, é uma forma de releitura do pensamento de Platão, de ampla repercussão sobre vários poetas e escritores, e que justamente se caracteriza pela mescla das teses do filósofo com elementos de procedência diversa, aplicados à defesa de convicções religiosas e místicas (supostamente reveladas ao homem em um plano anterior, e por ele redescobertas pela via da intuição religiosa e da reflexão sobre si mesmo). ${ }^{69}$

Adolfo Casais Monteiro, um dos primeiros teóricos a meditar sobre o significado e o alcance do ocultismo na poesia de Fernando Pessoa, destaca o cunho racionalista de que se reveste a manifestação do mesmo em sua poesia:

"O ocultismo de Pessoa é, em meu entender, ainda uma construção racional
- o que não o impediria de corresponder a 'um anseio essencial, doloroso,
imenso.' A visão de Pessoa não é a de um iluminado, mas a dum racionalista,
até por vezes dum positivista. E se ele encontrou no ocultismo o que parece

${ }^{68}$ A teoria platônica é objeto de várias reflexões teóricas de Fernando Pessoa. Cf.: PESSOA, 1995. p.541-2 e outros. Registra António Pina Coelho que "República" consta da biblioteca do poeta, em tradução inglesa. Cf. COELHO, 1971. p.50-1.

${ }^{69}$ O Neoplatonismo, como escola filosófica, foi fundado por Ammonio Saccas, no século II d.C., tendo como maior representante Plotino. Ressurge, posteriormente, na Renascença, defendido por Marsilio Ficino, repetindo com algumas variações as teses centrais de Plotino, acrescentando-lhes contudo uma peculiar mistura de Aristotelismo, filosofia patrística e escolástica, teosofia, matemática árabe, astrologia e crendices diversas. 
ter sido um dos interesses fundamentais do seu espírito ... quer me parecer que isso se deve precisamente ao carácter de 'construção racional' oferecido pelas vastas perspectivas da ciência do oculto ...,

Benedito Nunes e Jacinto do Prado Coelho se pronunciam em sentido parecido. O primeiro observa que a temática esotérica, embora recorrente, representa um veio secundário da meditação pessoana, sendo suscitada apenas para subsidiar a abordagem de problemas filosóficos primordiais, tais como a verdade extra-fenomênica, a ilusoriedade do conhecimento sensível, a preexistência da alma. A própria teosofia, que tanto abalo teria causado inicialmente a Fernando Pessoa, resultaria finalmente ".. subjugada, assimilada e convertida num instrumento de criação poética”. ${ }^{71} \mathrm{O}$ segundo ressalta que "Fernando Pessoa é um 'místico' mas 'racional', na sua própria definição; um idealista aristotélico." 72

Leyla Perrone-Moisés é outra estudiosa que se mostra bastante reticente quanto à interpretação ocultista dos textos poéticos pessoanos. Segundo seu entendimento, na maioria dos casos, há uma maior pertinência da explicação psicanalítica, particularmente de cunho lacaniano. Dentre os exemplos por ela selecionados, estão os seguintes versos, extraídos do Cancioneiro e de poesias inéditas: "Houve em mim várias almas sucessivas / Ou sou um só inconsciente ser?" [763]; "E eu sinto a minha vida de repente / Presa por uma corda de Inconsciente / A qualquer mão noturna que me guia” [75]; "Que parte de mim que eu desconheço é que me guia?" [76]; "Meu ser vive na Noite e no Desejo / Minha alma é uma lembrança que há em mim." [548]. Ademais,

\footnotetext{
${ }^{70}$ MONTEIRO, A. C. apud LIND, 1970, p.271.

${ }^{71}$ NUNES, 1969. p.254. O filósofo se refere, naturalmente, ao relato de Fernando Pessoa sobre o impacto causado pela leitura de um escrito teosófico de Leadbeater, por ele traduzido em 1915.

${ }^{72}$ Prefácio de: PESSOA. 1973, p.XIX..
} 
acrescenta ela, em reforço da sua argumentação anti-ocultista, que, também nos textos psicanalíticos de Lacan, são freqüentes as metáforas esotéricas a propósito da teorização do inconsciente — "O desejo do Outro é um Deus obscuro" —, sem que, por isso, se possa interpretar nesse sentido os seus argumentos. ${ }^{73}$

A controvérsia envolve, também, certos momentos da prosa de Fernando Pessoa. Penso, em especial, no "profetismo" expresso no já citado ensaio sobre a nova poesia portuguesa, geralmente aproximado do misticismo saudosista de Teixeira de Pascoais.

A propósito, vale lembrar que, conforme adverte o próprio Pessoa, o seu "profetismo" procura se ancorar em encadeamentos dedutivos de natureza racionalista, de modo que se por um lado, sua conclusão coincide com as intuições proféticas de Pascoais, por outro, o seu fundamento não se esgota no mero cumprimento de um plano divino providencial, incluindo igualmente uma racionalização do devir histórico: "Tudo isso, que a fé e a intuição dos místicos deu a Teixeira de Pascoais, vai o nosso raciocínio matematicamente confirmar.",74

Com efeito, mesmo sem um rigor caracteristicamente hegeliano, há uma tentativa de racionalização subjacente à "profecia" sobre o surgimento do "grande Poeta" português, que encarnará esse momento de glória de seu povo e o Espírito do mundo em seu processo de autoconsciência:

\footnotetext{
${ }^{73}$ PERRONE-MOISÉS, 1990. p.76-8.

${ }^{74}$ PESSOA, 1995. p.366.
} 
“... consoante todas as analogias ${ }^{75}$ no-lo impõem, a alma portuguesa atingirá em poesia o grau correspondente à altura a que a filosofia já está erguida. Deve estar para muito breve, portanto, o aparecimento do poeta supremo da nossa raça, e, ousando tirar a verdadeira conclusão que se nos impõe, pelos argumentos que o leitor viu, o poeta supremo da Europa, de todos os tempos. É um arrojo dizer isto? Mas o raciocínio assim o quere.,"

${ }^{75}$ É útil lembrar, a respeito do termo "analogias", que, embora a lógica positivista e a metodologia da ciência do século XIX tenham colocado em dúvida o modo de raciocínio que ele designa, e seja mais difundido o sentido secundário de "extensão provável do conhecimento mediante semelhanças genéricas", há um sentido próprio e restrito - de "igualdade de relações" - que é de amplo uso no campo da matemática, da filosofia e também da lógica, da metodologia e da física hodiernas (Cf. ABBAGNANO, 1994. p.67-71).

${ }^{76}$ PESSOA, 1995. p.396. 


\section{OS POETAS FICCIONAIS}

No presente capítulo, tomo como objeto de exame a obra dos três poetaspersonagens que integram as "Ficções do Interlúdio": Alberto Caeiro, Ricardo Reis e Álvaro de Campos. Examino-os segundo a ordem em que estão aqui citados, que é a de seu surgimento dentro da "coterie inexistente", criada por Fernando Pessoa, destacando não apenas os traços que os peculiarizam estilisticamente, mas também os sentidos filosóficos que neles se consubstanciam.

\subsection{Alberto Caeiro}

Se há um poeta cuja obsessão é refletir, no interior da própria poesia, sobre as relações entre o pensamento e a linguagem, esse poeta, por mais paradoxal que pareça, é Alberto Caeiro, o Mestre.

Coerentemente com a tese sensacionista do retorno à pura imediatidade da sensação, Alberto Caeiro é o defensor de um objetivismo integral, cujo escopo é reduzir o conhecimento à captação das sensações, em sua imediatidade: "Sou o Descobridor da Natureza. / Sou o Argonauta das sensações verdadeiras./ Trago ao Universo um novo

\footnotetext{
${ }^{1}$ PESSOA, 1995. p.96. Nesta passagem, esclarece o poeta: "Criei, então, uma coterie inexistente. Fixei tudo em moldes de realidade. Graduei as influências, conheci as amizades".
} 
Universo / Porque trago ao Universo ele-próprio", é como ele se apresenta, a certa altura do poema [251] de "O Guardador de Rebanhos".

A sua intenção programática é, de fato, integralmente empirista e objetivista, hostil a tudo que não pertence ao próprio ato de sentir e que possa se interpor entre a sensação e o seu objeto:

\section{(..)}

Creio no mundo como num malmequer, Porque o vejo. Mas não penso nele Porque pensar é não compreender... O Mundo não se fez para pensarmos nele (Pensar é estar doente dos olhos)

Mas para olharmos para ele e estarmos de acordo ...

Eu não tenho filosofia: tenho sentidos ...

Se falo na Natureza não é porque saiba o que ela é, Mas porque a amo, e amo-a por isso, Porque quem ama nunca sabe o que ama. Nem sabe por que ama, nem o que é amar ...

Amar é a eterna inocência, E a única inocência não pensar ...

Deixando de lado os aspectos poéticos, as inflexões retóricas e estilísticas, e considerando-se apenas o que dizem explicitamente os enunciados dessas três estrofes, é fácil detectar o tom de hostilidade a toda intervenção do pensar dentro do processo de conhecimento. Pensar chega a ser uma doença, significa "estar doente dos olhos". Todo o conhecimento se reduz ao que é apreendido pelos sentidos: "Creio no mundo como num malmequer, / Porque o vejo. ...”, e aqui é preciso reparar que se trata de uma forma de empirismo bem singular, pois acredita piamente, ou pelo menos diz acreditar, na perfeita correspondência das percepções com os objetos a que se referem. Com efeito, é um empirismo inteiramente diverso do de Álvaro de Campos e mesmo de Fernando 
Pessoa ortônimo, cuja tônica subjetivista é bem mais próxima da visão psicologista teorizada por David Hume - expoente máximo dessa corrente filosófica, na era moderna e cuja base filosófica é a convicção da impossibilidade de se comprovar, pela experiência, a conexão das percepções com os objetos, donde conclui o filósofo pela recusa de tal suposição. ${ }^{2}$

Em certa medida, os poemas Alberto Caeiro revelam um empenho de consubstanciação da temática empirista e objetivista com a forma do discurso poético. Isto pode ser visto, por exemplo, na passagem abaixo, extraída do poema que recebe o número [229], na edição em que me baseio:

O que nós vemos das cousas são as cousas.

Por que veríamos nós uma cousa se houvesse outra?

Por que é que ver e ouvir seria iludirmo-nos

Se ver e ouvir são ver e ouvir?

O essencial é saber ver,

Saber ver sem estar a pensar,

Saber ver quando se vê

E nem pensar quando se vê

Nem ver quando se pensa.

(...)

Observe-se a sintonia entre a objetividade perceptiva defendida e a linguagem que exprime essa idéia - direta, substantiva, tautológica, liberta de rimas, convenções métricas e ornamentos.

${ }^{2}$ Cf. HUME, 1973. p.193. A propósito, vale lembrar que o referido pressuposto humeano está bem presente não só na poesia de Fernando Pessoa ortônimo, mas também em várias passagens da sua prosa, por exemplo: "A certeza - isto é, a confiança no caráter objetivo das nossas percepções, e na conformidade das nossas idéias com a 'realidade' ou a 'verdade' - é um sintoma de ignorância ou de loucura." (PESSOA, 1995. p.557-8). Mais adiante: até a "certeza" matemática é relativa; só é certeza dentro da matemática, "... é apenas um critério subjetivo de verificar impressões que são forçosamente subjetivas...”, de modo que, “... longe de nos aproximar de uma 'objetividade' certamente objetiva, antes dela nos afasta [...]: onde julgamos ter uma objetividade temos apenas duas subjetividades" (PESSOA, 
Desde o primeiro verso — "O que nós vemos das cousas são as cousas" — a tautologia tem um papel decisivo, concretizando estilisticamente a intransitividade, a opacidade, dessa visão de mundo integralmente objetivista e inteiramente confiante na conexão das percepções com os objetos: pela tautologia, as coisas são remetidas apenas a si mesmas.

Igualmente, no terceiro e quarto versos — "Por que é que ver e ouvir seria iludirmo-nos / Se ver e ouvir são ver e ouvir?" - , a pergunta, tautologicamente formulada, acentua o imanentismo, o fechamento do discurso.

Na segunda estrofe, a essencialidade dessa ciência do "Saber ver" é sublinhada por uma outra figura retórica, a anáfora.

Por outro lado, observando-se esses mesmos exemplos que acabo de citar, é difícil não notar a incongruência dessa linguagem tautológica, de flagrante teor antiracionalista, com o intelectualismo que se denuncia em outros aspectos da sua estruturação: na própria feição argumentativa do discurso, no modo como contesta as opiniões contrárias, Alberto Caeiro faz afirmações dogmáticas, usando uma retórica tipicamente racionalista, fundada em toda uma série de abstrações.

De fato, isto acontece em praticamente todos os poemas-Caeiro, o que nos convida a uma meditação sobre até que ponto é adequada a sua difundida caracterização como “... o sensacionista puro e absoluto que se curva diante das sensações qua exterior e nada mais admite",3

1995. p.559-60).

${ }^{3}$ PESSOA (REIS), 1995. p.130. 
Passemos a mais um poema de "O Guardador de Rebanhos":

[215]

"Olá, guardador de rebanhos,

Aí à beira da estrada,

Que te diz o vento que passa?"

"Que é vento, e que passa,

E que já passou antes,

E que passará depois.

E a ti o que te diz?"

"Muita cousa mais do que isso.

Fala-me de muitas outras cousas.

De memórias e de saudades

E de cousas que nunca foram."

"Nunca ouviste passar o vento.

$\mathrm{O}$ vento só fala do vento.

O que lhe ouviste foi mentira,

E a mentira está em ti."

Trata-se de um diálogo entre o "guardador de rebanhos" e um interlocutor desconhecido. O tema é o passar do vento e seu possível poder sugestivo e evocativo. É ostensivo o contraste entre os dois discursos. O do "guardador de rebanhos" é taxativo, tautológico, bem adequado ao seu situar-se “à beira”, que já é uma metáfora da sua postura de mero contemplante do que está à sua volta. O do interlocutor desconhecido é evocativo, sugestivo de associações indefinidas, "De memórias e de saudades / E de cousas que nunca foram", criando um halo de indefinição entre o objetivo e o subjetivo, entre o interno e o externo.

Na última estrofe, o "guardador de rebanhos" repele esse subjetivismo, reiterando com mais uma tautologia a sua visão de mundo opaca e integralmente objetivista: 
"Nunca ouviste passar o vento. / O vento só fala do vento. / O que lhe ouviste foi mentira, / E a mentira está em ti."

O próximo exemplo é extraído da série "Poemas Inconjuntos":

O Universo não é uma idéia minha.

A minha idéia do Universo é que é uma idéia minha.

A noite não anoitece pelos meus olhos,

A minha idéia da noite é que anoitece pelos meus olhos.

Fora de eu pensar e de haver quaisquer pensamentos

A noite anoitece concretamente

E o fulgor das estrelas existe como se tivesse peso.

Composto de uma só estrofe de sete versos, esse curto poema tenta aproximar o conteúdo ideativo objetivista e a forma poética, não apenas optando pelo discurso direto e impessoal, pela estruturação irregular e pelo uso do verso livre, desobediente a convenções, mas também elegendo como constantes estilísticas o quiasmo (minha idéia [...] idéia minha), a anáfora ("pelos meus olhos”), o pleonasmo ostensivamente repetido (“A noite anoitece"; "A noite não anoitece"). No sentido de realçar a impessoalidade e o caráter categórico, autoritário, do discurso, é também digno de nota o emprego dos verbos sempre ou na terceira pessoa do singular, intercalando a forma negativa e a afirmativa, ou no infinitivo, pessoal e impessoal (“Fora de eu pensar e de haver ...").

Outros exemplos podem ser citados, no sentido de mostrar que, paralelamente à expressão do conteúdo flagrantemente anti-racionalista, a forma poética se carrega muitas vezes de elementos retóricos e estilísticos notoriamente intelectualizados, colocando em xeque o sensacionismo "integral" de Alberto Caeiro: 


\section{(...)}

Vi que não há Natureza,

Que Natureza não existe,

Que há montes, vales, planícies,

Que há árvores, flores, ervas,

Que há rios e pedras,

Mas que não há um todo a que isso pertença,

Que um conjunto real e verdadeiro

É uma doença das nossas idéias.

A Natureza é partes sem um todo.

Isto é talvez o tal mistério de que falam.

A passagem acima transcrita constitui a segunda estrofe do citado poema. É notório que, embora queira se referir aos elementos naturais de uma maneira objetivista, sem submetê-los a algum tipo de ordenação racional, Alberto Caeiro argumenta o tempo todo, faz afirmações e negações dogmáticas, traindo a cada instante sua disposição objetivista ("Vi que não há ...”, “Que há ...”, " Mas que não há ...”). No terceiro, quarto e quinto versos - "Que há montes, vales, planícies, / Que há árvores, flores, ervas, / Que há rios e pedras," - ele lança mão da citação assindética dos elementos da natureza, de certo para criar, pela ausência de conjunções, uma imagem da desarticulação desses elementos e do fragmentarismo que caracteriza o seu olhar objetivo. Entretanto, como bem assinala Maria Helena Nery Garcez,

\footnotetext{
“... se, por um lado, o conteúdo explícito do poema diz isso e a linguagem também o diz, por outro, a mesma linguagem de Caeiro trai a aceitação de uma certa ordem na Natureza. Podemos observar que o heterónimo cita primeiro três elementos do mundo inanimado, mais concretamente, três acidentes geográficos pertencentes à ordem mineral: 'montes, vales, planícies' e depois, coloca lado a lado três seres do mundo vegetal: 'árvores, flores, ervas', para a seguir voltar aos inanimados: 'rios e pedras'. É curioso que num poema onde se contesta uma visão organizada na Natureza, obedeça-se, de certa forma, à ordenação tradicional." ${ }^{4}$
}

\footnotetext{
${ }^{4}$ GARCEZ, 1985. p.163.
} 
O tom professoral, axiomático, "filosofal", bem parecido com o do Zaratustra, de Nietzsche, é de fato um aspecto recorrente no poeta-personagem Alberto Caeiro, e que se põe em significativo contraste com o seu teor objetivista e anti-racionalista:

Todas as opiniões que há sobre a natureza

Nunca fizeram crescer uma erva ou nascer uma flor.

Toda a sabedoria a respeito das cousas

Nunca foi cousa em que pudesse pegar como nas cousas;

Se a ciência quer ser verdadeira,

Que ciência mais verdadeira que a das cousas sem ciência?

Fecho os olhos e a terra dura sobre que me deito

Tem uma realidade tão real que até as minhas costas a sentem.

Não preciso de raciocínio onde tenho espáduas.

Observe-se que, de um lado, a linguagem simples e direta dos quatro versos iniciais realça o imanentismo da visão de mundo comunicada pelo eu poético — o uso da tautologia, no terceiro e quarto versos, reforça a opacidade dessa visão ("Toda a sabedoria a respeito das cousas / Nunca foi cousa em que pudesse pegar como nas cousas"), o que é ainda mais acentuado, no oitavo verso, pela construção pleonástica (“... uma realidade tão real que ...). Do outro, o tom sentencioso, dogmático, compromete essa profissão de objetivismo sensorialista e anti-intelectualista ("Todas as opiniões ... / Nunca fizeram ...”; “Toda a sabedoria .../ Nunca foi ...”). Note-se o tom polêmico e provocativo da pergunta formulada no quinto e sexto versos: "Se a ciência quer ser verdadeira, / Que ciência mais verdadeira que a das cousas sem ciência?”.

Esse mesmo tom professoral e aforismático se faz notar em várias outras passagens da obra de Alberto Caeiro, sempre em contraste com o teor anti-reflexivo dos enunciados, o que acaba por colocar sob suspeita o seu objetivismo absoluto: "Assim como falham as palavras quando querem exprimir qualquer pensamento, / Assim falham 
os pensamentos quando querem exprimir qualquer realidade" [284]; "O único sentido íntimo das coisas/ É elas não terem sentido íntimo nenhum" [210]; "Basta existir para se ser completo" [272]; "Um dia de chuva é tão belo como um dia de sol. / Ambos existem; cada um como é” [279]; “A única afirmação é ser” [286]; “Amar é a eterna inocência, / E a única inocência não pensar...” [207].

Com significativa freqüência, esse tom "filosofal" aparece associado a um notório fatalismo, por vezes quase "maometano", o que só vem agravar a suspeita já lançada sobre o seu sensacionismo "integral". No plano estilístico, esse fatalismo se faz notar, por exemplo, no “... uso freqüente do verbo 'dever', do substantivo 'destino' e do advérbio "assim",": "A ave passa e esquece, e assim deve ser" [248]; "Aceito as dificuldades da vida porque são o destino" [292]; “...Assim é e assim seja...” [226]; “Assim, porque assim o sinto, é que é meu dever senti-lo...” [227]; "Porque tudo é como é e assim é que é/ E eu aceito ...” [228]; “Aceito a injustiça como aceito uma pedra não ser redonda. / E um sobreiro não ter nascido pinheiro ou carvalho.” [268].

Sem pretender multiplicar os exemplos, cito mais um poema desta série:

Sou um guardador de rebanhos.

O rebanho é meus pensamentos

E os meus pensamentos são todos sensações.

Penso com os olhos e com os ouvidos

E com as mãos e os pés

E com o nariz e a boca.

Pensar uma flor é vê-la e cheirá-la

E comer um fruto é saber-lhe o sentido.

Por isso quando num dia de calor

Me sinto triste de gozá-lo tanto,

E me deito ao comprido na erva,

5 GARCEZ, 1985. p.150. 
E fecho os olhos quentes,

Sinto todo o meu corpo deitado na realidade,

Sei a verdade e sou feliz.

Observe-se que, tão logo se apresenta como "um guardador de rebanhos", esse poeta-pastor opera uma redução do pensar ao sentir: "E os meus pensamentos são todos sensações. / Penso com os olhos e com os ouvidos / E com as mãos e os pés / E com o nariz e a boca." Como se pode notar, nos seis versos que compõem a primeira estrofe, a linguagem é direta, substantiva. Há apenas dois verbos ("ser" e "pensar"). O segundo e o terceiro versos, bem como o quarto, quinto e sexto, interligam-se através do “enjambement”, recorrendo além disso à figura do polissíndeto. Tudo isso reforça, evidentemente, a idéia de um discurso espontâneo, livre de ordenação racional e obediência a convenções.

Chamo a atenção, entretanto, para outros aspectos que denunciam o implícito racionalismo que se expressa ao longo do poema: primeiramente, a predominância dos verbos na primeira pessoa do singular do presente do indicativo; em segundo lugar, o tom "filosofal", axiomático, dos dois versos que compõem a segunda estrofe ("Pensar uma flor é vê-la e cheirá-la / E comer um fruto é saber-lhe o sentido.”); terceiro, passando ao verso de encerramento — "Sei a verdade e sou feliz" — note-se o uso provocativo de dois verbos bem típicos do repertório filosófico racionalista ("Sei” e “sou”), aplicados ao contexto inverso de exaltação sensorialista.

Em certos momentos, o escopo objetivista parece ficar entre parênteses, verificando-se mesmo uma entrega a digressões e devaneios: 
O meu olhar é nítido como um girassol.

Tenho o costume de andar pelas estradas

Olhando para a direita e para a esquerda,

E de vez em quando olhando para trás...

E o que vejo a cada momento

É aquilo que nunca antes eu tinha visto,

E eu sei dar por isso muito bem...

Sei ter o pasmo essencial

Que tem uma criança se, ao nascer,

Reparasse que nascera deveras...

Sinto-me nascido a cada momento

Para a eterna novidade do Mundo...

(...)

No primeiro verso da estrofe transcrita, o eu poético invoca a imagem do girassol — flor cujo nome se deve à sua ligação com o movimento solar — como metáfora da nitidez do seu olhar objetivo, que, supostamente, se move em função dos objetos contemplados e não do seu interesse pessoal. Por outro lado, as numerosas reticências ("E de vez em quando olhando para trás..."; "E eu sei dar por isso muito bem..."; "Reparasse que nascera deveras..."; "Para a eterna novidade do Mundo...") geram tensão, expectativa quanto aos significados que ficam em suspenso - o uso dessas reticências é ambíguo, pois sugere ou evoca algo que é negado logo em seguida (o “olhando para trás ...", por exemplo, embora possa sugerir um resgate de impressões passadas, refere-se à realidade externa que circunda o sujeito poético); além disso, servem para reforçar o contraste com o fechamento dogmático expresso, por exemplo, pelo verbo saber, sempre na primeira pessoa do singular do presente do indicativo ("E eu sei $[\ldots] /$ Sei ter ...").

Tanto quanto Fernando Pessoa ortônimo e os outros heterônimos, Alberto Caeiro está em busca da verdade. Só que, do seu ponto de vista, essa busca não consiste 
em desvelar as razões ocultas por detrás das aparências, mas, antes, em deter-se nas aparências, "abrir" os olhos e "ver" o que está à sua frente:

(...)

O mistério das cousas? Sei lá o que é mistério!

O único mistério é haver quem pense no mistério.

Quem está ao sol e fecha os olhos,

Começa a não saber o que é o sol

E a pensar muitas cousas cheias de calor.

Mas abre os olhos e vê o sol,

E já não pode pensar em nada,

Porque a luz do sol vale mais que os pensamentos

De todos os filósofos e de todos os poetas.

A luz do sol não sabe o que faz

E por isso não erra e é comum e boa.

Metafísica? Que metafísica têm aquelas árvores?

A de serem verdes e copadas e de terem ramos

$\mathrm{E}$ a de dar fruto na sua hora, o que não nos faz pensar,

A nós, que não sabemos dar por elas.

Mas que melhor metafísica que a delas,

Que é a de não saber para que vivem

Nem saber que o não sabem?

“Constituição íntima das cousas”...

"Sentido íntimo do Universo"...

Tudo isto é falso, tudo isto não quer dizer nada.

É incrível que se possa pensar em cousas dessas.

É como pensar em razões e fins

Quando o começo da manhã está raiando, e pelos lados das árvores

Um vago ouro lustroso vai perdendo a escuridão.

Pensar no sentido íntimo das cousas

É acrescentado, como pensar na saúde

Ou levar um copo à água das fontes.

O único sentido íntimo das cousas

É elas não terem sentido íntimo nenhum.

(...) 
Desse prisma, o ato de pensar constitui um desvio perceptivo, uma doença mesmo, que atinge o ser humano em geral, mas de que Alberto Caeiro se acha livre: "Nasci sujeito como os outros a erros e a defeitos, / Mas nunca ao erro de querer compreender demais, / Nunca ao erro de querer compreender só com a inteligência. / Nunca ao defeito de exigir do Mundo / Que fosse qualquer cousa que não fosse o Mundo [292]; “Os poetas místicos são filósofos doentes,/ E os filósofos são homens doidos" [233]; "O que penso eu do mundo? / Sei lá o que penso do mundo! / Se eu adoecesse pensaria nisso" [210]. É que o pensamento é um obstáculo, um intermediário que se interpõe entre o saber e a verdade imediata dos sentidos. E, além disso, exprimese através da linguagem, o que implica um duplo obstáculo, um duplo distanciamento “Estas verdades não são perfeitas porque são ditas. / E antes de ditas pensadas" [286].

A questão crucial que se põe para Alberto Caeiro é, pois, achar um meio de encurtar essa distância, chegar mais próximo das coisas, ou seja, “... encostar as palavras à idéia / E não precisar dum corredor / Do pensamento para as palavras”. Escrever em versos é, quem sabe, uma solução. Na poesia, a palavra se "encosta" à idéia, apresentase, ela própria, como um significado, um objeto. Por isso, prefere escrever em versos:

Deste modo ou daquele modo.

Conforme calha ou não calha.

Podendo às vezes dizer o que penso,

E outras vezes dizendo-o mal e com misturas,

Vou escrevendo os meus versos sem querer,

Como se escrever não fosse uma cousa feita de gestos,

Como se escrever fosse uma cousa que me acontecesse

Como dar-me o sol de fora.

Procuro dizer o que sinto

Sem pensar em que o sinto.

Procuro encostar as palavras à idéia

E não precisar dum corredor

Do pensamento para as palavras 
Nem sempre consigo sentir o que sei que devo sentir.

O meu pensamento só muito devagar atravessa o rio a nado

Porque lhe pesa o fato que os homens o fizeram usar.

(...)

Como foi visto, os poemas desse poeta-pastor, supostamente inculto — para quem "Pensar incomoda como andar à chuva / Quando o vento cresce e parece que chove mais" - não conseguem realizar de todo essa almejada aproximação da palavra com a "idéia", prevalecendo, muitas vezes, um discurso notoriamente intelectualizado.

Essa contradição interna remete à própria gênese dos poemas Caeiro. Penso, antes de mais nada, no fato de que uma das motivações declaradas por Fernando Pessoa para a criação desse poeta-personagem foi a de ter sido esse ele inventado com o intuito “... de fazer uma partida ao Sá-Carneiro ...”, o que sugere ter sido ele concebido como uma antítese deste poeta e amigo pessoal de Fernando Pessoa. Assim, considerando-se que Sá-Carneiro é, sabidamente, um "idealista”, um poeta do tipo subjetivo, que, como observa Maria Helena Nery Garcez, “... opta pela rejeição da Natureza ou, mais radicalmente ainda, pela rejeição do Real, [...] que não convida seus leitores ao lazer, ao descanso no lúdico, pois, pelo contrário, o faz partícipe de suas numerosas inquietações e dilaceramentos interiores", , é fácil entender o porquê de Alberto Caeiro ser um poeta bucólico, afeito à vida no campo, adepto de um objetivismo radical, que o leva a colher “... a sensação das coisas como são, sem acrescentar a isto quaisquer elementos de pensamento pessoal, convenção, sentimento ou qualquer outro lugar da alma."8

\footnotetext{
${ }^{6}$ PESSOA, 1995. p. 96.

${ }^{7}$ GARCEZ, 1990.p.94-5.

${ }^{8}$ PESSOA (REIS), 1995. p.130.
} 
A essa constituição, já de início, essencialmente dialógica e interdiscursiva da poesia Alberto Caeiro, acrescentam-se outras pistas interpretativas, como por exemplo, a contraposição ao saudosista Teixeira de Pascoaes (um "Pascoaes virado do avesso, sem o tirar do lugar onde está dá isto - Alberto Caeiro"99), ou, sob outros aspectos, ao neoclassicismo apolíneo e racionalista de Ricardo Reis, ao subjetivismo dionisíaco de Álvaro de Campos, ou ainda, ao subjetivismo/ misticismo/ simbolismo da poesia ortônima, numa longa série de referências e paralelos, já descobertos ou ainda por descobrir.

Essa riqueza de referencias intertextuais confere-lhe um perfil complexo, de certo inadequado a um jovem guardador de rebanhos, por um lado, descrito como um "Ignorante da vida e quase ignorante das letras, quase sem convívio nem cultura...", sem “... profissão nem educação quase alguma"" ; por outro, dotado de uma perspicácia especulativa invejável, capaz de pôr em xeque as mais conceituadas e elaboradas doutrinas da filosofia ocidental. Repare-se, por exemplo, no longo poema que abaixo transcrevo, onde o poeta-pastor se revela um crítico hábil e competente da filosofia de Descartes:

Seja o que for que esteja no centro do Mundo,

Deu-me o mundo exterior por exemplo de Realidade, E quando digo "isto é real", mesmo de um sentimento, Vejo-o sem querer em um espaço qualquer exterior, Vejo-o com uma visão qualquer fora e alheio a mim. Ser real quer dizer não estar dentro de mim.

Da minha pessoa de dentro não tenho noção da realidade.

Sei que o mundo existe, mas não sei se existo.

\footnotetext{
${ }^{9}$ PESSOA (REIS), 1995. p.128.

${ }^{10}$ PESSOA, 1995. p.115.

${ }^{11}$ PESSOA, 1995. p.97.
} 
Estou mais perto da existência da minha casa branca

Do que da existência interior do dono da casa branca.

Creio mais no meu corpo do que na minha alma,

Porque o meu corpo apresenta-se no meio da realidade.

Podendo ser visto por outros,

Podendo tocar em outros,

Podendo sentar-se e estar de pé,

Mas a minha alma só pode ser definida por termos de fora.

Existe para mim - nos momentos em que julgo que efetivamente existe -

Por um empréstimo da realidade exterior do Mundo.

Se a alma é mais real

Que o mundo exterior, como tu, filósofo, dizes,

Para que é que o mundo exterior me foi dado como tipo da realidade?

Se é mais certo eu sentir

Do que existir a cousa que sinto -

Para que sinto

E para que surge essa cousa independentemente de mim

Sem precisar de mim para existir,

E eu sempre ligado a mim-próprio, sempre pessoal e intransmissível?

Para que me movo com os outros

Em um mundo em que nos entendemos e onde coincidimos

Se por acaso esse mundo é o erro e eu é que estou certo?

Se o Mundo é um erro, é um erro de toda a gente,

E cada um de nós é o erro de cada um de nós apenas,

Cousa por cousa, o Mundo é mais certo.

Mas por que me interrogo, senão porque estou doente?

Nos dias certos, nos dias exteriores da minha vida,

Nos meus dias de perfeita lucidez natural,

Sinto sem sentir que sinto,

Vejo sem saber que vejo,

E nunca o Universo é tão real como então,

Nunca o Universo está (não é perto ou longe de mim,

Mas) tão sublimemente não-meu.

Quando digo "é evidente", quero acaso dizer "só eu é que o vejo"?

Quando digo "é verdade", quero acaso dizer "é minha opinião"?

Quando digo "ali está", quero acaso dizer "não está ali”?

E se isto é assim na vida, por que será diferente na filosofia?

Vivemos antes de filosofar, existimos antes de o sabermos,

E o primeiro fato merece ao menos a precedência e o culto.

Sim, antes de sermos interior somos exterior.

Por isso somos exterior essencialmente.

Dizes, filósofo doente, filósofo, enfim, que isto é materialismo.

Mas isto como pode ser materialismo, se materialismo é uma filosofia, Se uma filosofia seria, pelo menos sendo minha, uma filosofia minha, 
E isto nem sequer é meu, nem sequer sou eu?

Observe-se, desde a primeira estrofe, que o poema empreende uma direta contraposição à evidência intuitiva, sobre o qual Descartes assentava sua doutrina. Ao "Penso logo existo", enunciado cartesiano basilar, Caeiro contrapõe no oitavo verso: "Sei que o mundo existe, mas não sei se existo".

Para o filósofo francês, como se sabe, “... quer estejamos em vigília, quer dormindo, nunca nos devemos deixar persuadir senão pela evidência de nossa razão". ${ }^{12}$ Caeiro, pelo contrário, desloca toda a certeza para o que vem dos sentidos. Alguns recursos estilísticos consubstanciam poeticamente essa idéia: por exemplo, a repetição do verbo "ver", no início de dois versos consecutivos (quarto e quinto), acentuando-se o efeito dessa anáfora através do pleonasmo: "Vejo-o com uma visão ...". O sexto verso resume, numa fórmula lapidar, com ares de axioma filosófico — "Ser real quer dizer não estar dentro de mim" - enquanto o oitavo verso nega, mais uma vez, o sentido da transparência do "Cogito" cartesiano — "Sei que o mundo existe, mas não sei se existo". A figura da anáfora reaparece no décimo terceiro, décimo quarto e décimo quinto versos ("Podendo" ...), de certo para recriar a insistente afirmação da realidade do corpo e da sua maior cognoscibilidade em relação à alma.

As inversões dos significados cartesianos vão se sucedendo, desenvolvendose toda a contra-argumentação no sentido de pôr em xeque a evidencia do Cogito: se, para Descartes, a certeza primeira é a existência da alma — mais facilmente cognoscível do que o corpo, pois é “... uma substância cuja essência ou natureza consiste apenas em

\footnotetext{
${ }^{12}$ DESCARTES, 1973. p.58.
} 
pensar, e que, para ser, não necessita de nenhum lugar, nem depende de qualquer coisa material" ${ }^{\prime 3}$ —, para Caeiro, inversamente, é o corpo a certeza primordial, justamente porque imerso na realidade exterior. O corpo é mais real, mais crível do que a alma, que só pode ser definida de fora para dentro, implicando portanto um distanciamento cognoscitivo (e não a auto-evidência postulada por Descartes).

As perguntas formuladas na quarta estrofe são uma provocação direta ao filósofo francês, não mencionado explicitamente, mas facilmente identificável pelo leitor versado em teorias filosóficas. Observe-se alguns recursos retóricos que dão realce ao tom polêmico e argumentativo desse discurso: a) a subdivisão em duas interrogações (do primeiro ao sexto verso e do sétimo ao nono) e uma resposta (do décimo ao décimo segundo); b) o uso abundante de condicionais, tanto nas perguntas (“Se é mais .../ [...] / Para que ...?"; "Para que .../ [...] Se por acaso ...?”) quanto na resposta (“Se o Mundo é...").

Compondo-se de um só verso, a estrofe seguinte confere realce especial à pergunta formulada — "Mas por que me interrogo, senão porque estou doente?" —, enquanto a sexta estrofe, invertendo o sentido do conhecido postulado cartesiano interpõe a primazia da vida, da existência, sobre o pensar: "Vivemos antes de filosofar, existimos antes de o sabermos / E o primeiro fato merece ao menos a precedência e o culto."

${ }^{13}$ DESCARTES, 1973. p.55. 
A última estrofe satiriza com ironia mordaz não apenas Descartes, mas o filósofo, de modo geral: "Dizes, filósofo doente, filósofo, enfim, ...”.

Note-se, ainda, o tom polêmico, argumentativo da interrogação provocativa que finaliza o poema: "Mas isto como pode ser materialismo, se materialismo é uma filosofia, / Se uma filosofia seria, pelo menos sendo minha, uma filosofia minha, / E isto nem sequer é meu, nem sequer sou eu?".

O poema seguinte pertence à série "O guardador de rebanhos" e exibe um outro tipo de intertexto filosófico, implícito naturalmente, mas não menos indicativo da sua argúcia reflexiva e notável erudição filosófica:

Às vezes, em dias de luz perfeita e exata,

Em que as cousas têm toda a realidade que podem ter,

Pergunto a mim próprio devagar

Por que sequer atribuo eu

Beleza às cousas.

Uma flor acaso tem beleza?

Tem beleza acaso um fruto?

Não: têm cor e forma

E existência apenas.

A beleza é o nome de qualquer cousa que não existe

Que eu dou às cousas em troca do agrado que me dão.

Não significa nada.

Então por que digo eu das cousas: são belas?

Sim, mesmo a mim, que vivo só de viver,

Invisíveis, vêm ter comigo as mentiras dos homens

Perante as cousas,

Perante as cousas que simplesmente existem.

Que difícil ser próprio e não ver senão o visível! 
Logo a um primeiro contato, salta à vista uma curiosa sintonia com certas passagens da meditação de Kant sobre o fundamento do juízo do belo: "Uma flor acaso tem beleza?/ [...] / Não: têm cor e forma / E existência apenas. / A beleza é o nome de qualquer cousa que não existe / Que eu dou às cousas em troca do agrado que me dão."14

Mas, se assim é, se a beleza não reside em alguma propriedade objetiva, "Então por que digo eu das cousas: são belas?”

Observe-se que esse verso parece resumir a questão crucial que motiva Kant a buscar o fundamento do juízo estético: se dizemos que as coisas são belas em virtude do agrado que nos dão, como se explica a pretensão de validez universal do juízo de gosto, ou seja, porque, então, falamos da beleza “... como se ela fosse uma propriedade das coisas"? ${ }^{15}$

Entretanto, a breve incursão de Caeiro pela "Analítica do belo" pára por aí, pois, obviamente, um sensacionista "puro e absoluto", como ele diz ser, não poderia aceitar a solução transcendental oferecida pelo filósofo - a saber, que as leis internas da consciência constituem o fundamento do juízo estético, justificando-se dessa forma a sua pretensão de validez universal. Na verdade, a retomada dos argumentos kantianos, nas duas primeiras estrofes do poema, é apenas aparente, constituindo uma estratégia

\footnotetext{
${ }^{14}$ Para Kant, como se sabe, a beleza não é uma qualidade objetiva, mas decorre do fato de que uma certa finalidade, não referida a nenhum fim, é encontrada na percepção do objeto, de modo que “... a simples forma sem conhecimento do fim apraz por si própria no ajuizamento." (KANT, 1995. p.157). Em outro lugar: "... uma flor, por exemplo uma tulipa, é tida por bela porque em sua percepção é encontrada uma certa conformidade a fins, que do modo como a ajuizamos não é referida a absolutamente nenhum fim" (KANT, 1995. p.82n).

${ }^{15}$ KANT, 1995. p.57.
} 
provocativa, para gerar expectativa em relação a uma possível mudança de posição epistemológica.

Na última estrofe, Caeiro muda totalmente o tom do discurso e, em lugar de apresentar algum fundamento para os juízos humanos sobre a beleza, conclui pela sua total falta de fundamento: eles se incluem entre “... as mentiras dos homens / Perante as cousas, / Perante as cousas que simplesmente existem."

Repare-se, agora, nesse outro poema:

Passa uma borboleta por diante de mim E pela primeira vez no Universo eu reparo Que as borboletas não têm nem cor nem movimento, Assim como as flores não têm perfume nem cor.

A cor é que tem cor nas asas da borboleta,

No movimento da borboleta o movimento é que se move,

O perfume é que tem perfume no perfume da flor.

A borboleta é apenas borboleta.

E a flor é apenas flor.

A construção do primeiro verso ("Passa uma borboleta por diante de mim”) corrobora a visão de mundo objetivista, declarada por Alberto Caeiro. Observe-se que esse objetivismo é realçado por alguns recursos estilísticos: primeiramente, pelo início do verso com um verbo na terceira pessoa do singular; o sujeito da oração não é o contemplante mas "uma borboleta"; o contemplante é apenas uma mera referência espacial ("por diante de mim”) e vem em último lugar.

No quinto, sexto e sétimo versos — "A cor é que tem cor nas asas da borboleta, / No movimento da borboleta o movimento é que se move, / O perfume é que tem perfume no perfume da flor" - embora faça uso de uma tautologia ostensiva e, 
inclusive, de uma construção pleonástica (“o movimento é que se move”), faz-se notar o intelectualismo de suas ponderações: tempo, espaço, movimento, assim como cor e forma não são propriedades objetivamente dadas, mas condições da sensibilidade humana. ${ }^{16}$

No poema que se segue, Alberto Caeiro prossegue na mesma linha, deixando implícito que a temporalidade é um dado subjetivo, pertencente ao esquema perceptivo do sujeito e não à coisa em si, devendo, portanto, ser excluída:

Vive, dizes, no presente;

Vive só no presente.

Mas eu não quero o presente, quero a realidade;

Quero as cousas que existem, não o tempo que as mede.

O que é o presente?

É uma cousa relativa ao passado e ao futuro.

É uma cousa que existe em virtude de outras cousas existirem.

Eu quero só a realidade, as cousas sem presente.

Não quero incluir o tempo no meu esquema.

Não quero pensar nas cousas como presentes; quero pensar nelas como cousas.

Não quero separá-las de si-próprias, tratando-as por presentes.

Eu nem por reais as devia tratar.

Eu não as devia tratar por nada.

Eu devia vê-las, apenas vê-las;

Vê-las até não poder pensar nelas,

Vê-las sem tempo, nem espaço,

Ver podendo dispensar tudo menos o que se vê.

É esta a ciência de ver, que não é nenhuma.

16 Cf., a propósito, uma passagem de Fernando Pessoa sobre essa temática kantiana: "Notamos em primeiro lugar que o tempo e o espaço não são perceptíveis, isto é, não caem debaixo da nossa sensibilidade; o que se nos apresenta é o objeto extenso e durável, quero dizer, com extensão e duração. Mas, ao mesmo tempo, só podemos compreender esse objeto se ele tiver uma extensão e uma duração. Vemos portanto que o tempo e o espaço, assim como a forma, a cor, o peso, etc., não sendo coisas, mas sendo contudo necessários a elas para que as compreendamos são atributos gerais, ou condições da sensibilidade.” (PESSOA, 1995. p.531-2). 
Atente-se, particularmente, ao segundo verso da segunda estrofe ("Quero as cousas que existem, não o tempo que as mede"). Tempo e espaço são formas de medida, logo, elementos subjetivos, que relativizam as coisas entre si e em relação ao contemplante, impedindo que sejam captadas em si mesmas. O verso "Não quero incluir o tempo no meu esquema" sugere que, malgrado suas insistentes declarações de objetivismo total, Caeiro admite a existência de determinadas condições da sensibilidade, ou seja, da existência de um "esquema" perceptivo, que ele pretenderia, no entanto, modificar. O uso intensivo dos verbos "querer", "dever" ("Não quero ... quero"; "Eu não as devia ... / Eu devia ....") insinua certa consciência de que o objetivismo é uma meta inatingível.

Convém refletir sobre o sentido de todas essas insistentes incongruências. A propósito, vêm-me à lembrança a afirmação de Jacinto do Prado Coelho quanto à falta de unidade “...entre aquilo que Caeiro mostra ser e aquilo que diz ser e as idéias que defende..."17

De fato, Alberto Caeiro se diz um sensorialista objetivo, movido pelo sentir e não pelo pensar. Mas, em contraste com esse puro objetivismo sensualista, afirma coisas que vão bem além das sensações imediatas, coisas que implicam juízos sobre o ser. Caeiro poetiza as sensações, apresenta-as não em estado original, mas idealizadas. Ora, por um lado, essa intelectualização é coerente com o estabelecido pelo programa poético do Sensacionismo, segundo o qual, a base da arte é a sensação, mas não a sensação em

\footnotetext{
${ }^{17}$ COELHO, 1977. p.239.
} 
estado puro, que é mera "emoção sem sentido" e sim idealizada, trabalhada artisticamente. Por outro lado, é incoerente com o lema do objetivismo "integral".

Observando-se com mais atenção, Caeiro sabe que sua proposta de retornar ao estado de imediatidade originária da sensação é uma total utopia, pois supõe um embaraço axial: não se trata de um processo natural, mas, antes, de um processo extremamente artificial, pois implica uma espécie de desconstrução dos caminhos habituais do pensamento, um descondicionamento dos entraves da linguagem convencional, de tudo, enfim, que possa distanciar o ser das coisas e a sua revelação ${ }^{18}$. Mesmo proclamando-se um pastor inculto e ingênuo, Caeiro demonstra saber que os discursos não se referem às coisas mesmas, mas incorporam outros discursos, constituindo-se como um espaço conflitual e heterogêno. E isto requer esforço, raciocínio vigilante: "Mas isso (tristes de nós que trazemos a alma vestida!), Isso exige um estudo profundo, / Uma aprendizagem de desaprender" [229]. O mesmo pode ser observado nesse outro trecho:

\section{(...)}

Procuro despir-me do que aprendi,

Procuro esquecer-me do modo de lembrar que me ensinaram,

E raspar a tinta com que me pintaram os sentidos,

Desencaixotar as minhas emoções verdadeiras,

Desembrulhar-me e ser eu, não Alberto Caeiro,

Mas um animal humano que a Natureza produziu.

Compõe-se, a partir daí, um verdadeiro jogo de consonâncias e dissonâncias, que conferem a Caeiro um perfil poético ambíguo e multifacetado. Esse multifacetamen-

\footnotetext{
18 Trata-se, contudo, de uma epoché, em vários aspectos semelhante à praticada por Husserl, mas que, todavia, não tem escopo eidético. Caeiro não prega a suspensão do juízo como uma etapa de depuração para se chegar às essências, pois, mais precisamente, ele as nega.
} 
to suscita, na maioria das vezes, uma dupla leitura, o que nos remete ao tipo de leitor previsto por esses textos, ou seja, no seu "leitor-modelo".

Naturalmente, para ser capaz de perceber as ambigüidades e as sofisticadas referências intertextuais de Caeiro, o seu "leitor-modelo" não pode corresponder à pura objetividade sensorialista por ele preconizada. Antes, deve ser um leitor culto, dotado de perspicuidade e erudição. Em certa medida, isto já está implícito na análise dos poemas [207], [210], [214], [231], [233], [292], [293], [296]. Acrescento, portanto, apenas mais um breve exemplo:

Da minha aldeia vejo quanto da terra se pode ver no Universo...

Por isso a minha aldeia é tão grande como outra terra qualquer

Porque eu sou do tamanho do que vejo

E não do tamanho da minha altura...

Nas cidades a vida é mais pequena

Que aqui na minha casa no cimo deste outeiro.

$\mathrm{Na}$ cidade as grandes casas fecham a vista à chave,

Escondem o horizonte, empurram o nosso olhar para longe de todo o céu,

Tornam-nos pequenos porque nos tiram o que os nossos olhos nos podem dar, E tornam-nos pobres porque a nossa única riqueza é ver.

Consonante com o seu programa poético objetivista, o discurso do "guardador de rebanhos" procura refletir o fechamento de sua visão na pura imediatidade das percepções sensíveis, realçando a opacidade desse olhar inclusive pelo recurso da tautologia ("Da minha aldeia ..." / Por isso a minha aldeia..."; “.. quanto da terra...” / “... como outra terra ..."). Observe-se, entretanto, que os dois primeiros versos ("Da minha aldeia vejo quanto da terra se pode ver no Universo... / Por isso a minha aldeia é tão grande como outra terra qualquer") criam uma ambigüidade proposital: não se sabe se o poeta esta relativizando o contemplado ao ponto de vista do contemplante, ou o 
contrário. As reticências no final do primeiro verso reforçam essa expectativa, que só é resolvida no terceiro e quarto versos — "Porque eu sou do tamanho do que vejo / E não do tamanho da minha altura..." - com uma surpreendente inversão do significado habitual dos termos fundamentais da relação cognoscitiva (sujeito — objeto). Adotando um ponto de vista inverso ao do racionalismo epistemológico, o poeta descentra o sujeito do seu posto de pólo determinante do conhecimento, descrevendo-o como que determinado pelo objeto. Obviamente, o alcance epistemológico dessa inversão não é acessível a um leitor sem conhecimento filosófico.

Como se vê, é problemático enquadrar Alberto Caeiro em alguma corrente estilística ou filosófica. Em especial, não se pode qualificá-lo como um cético, pois, antes de mais nada, ele não suspende o juízo, apenas recomenda tal suspensão, mas não a pratica: pelo contrário, faz um discurso quase sempre dogmático, "professoral", doutrinário. Além disso, sua atitude é essencialmente empirista e anti-zetética, quer dizer, contrária à investigação. Aliás, melhor dizendo, a sua atitude é dúbia, ambígua: por um lado, proclama que não quer saber nada além do que tem diante dos olhos; por outro, pergunta o tempo todo, interrompendo constantemente o seu discurso com indagações provocativas, polêmicas, dirigidas a algum interlocutor imaginário. De contradição em contradição, de incongruência em incongruência, de negação em negação, incorporando intertextualmente figuras de pensamento e figuras de retórica, oriundas das mais diversificadas vertentes, Caeiro vai fazendo o seu anti-discurso e com isso levando ao limite as relações de poesia e filosofia, linguagem e pensamento. 


\subsection{Ricardo Reis}

Conhecido como o heterônimo "neoclássico", Ricardo Reis tenta realizar o objetivismo pregado pelo Mestre Alberto Caeiro, não pela via da imediatidade sensorial, purificada de intromissões subjetivas, mas pela via da submissão dos sentimentos e sensações à racionalidade dos cânones consagrados pela poesia da Antigüidade grecoromana.

Atenção, no entanto. Não se trata de uma simples acolhida da racionalidade do Classicismo grego, adotando seu modelo construtivo como um conjunto de normas impostas de fora para dentro, mas de uma verdadeira e própria introjeção de seus valores, de uma interiorização da sua disciplina, de modo que, pelo menos nas odes iniciais, exibe-se uma significativa correlação da forma com a visão de mundo por ele defendida. Isto pode ser visto, por exemplo, na ode abaixo:

No ciclo eterno das mudáveis coisas

Novo inverno após novo outono volve

À diferente terra

Com a mesma maneira.

Porém a mim nem me acha diferente

Nem diferente deixa-me, fechado

Na clausura maligna

Da índole indecisa.

Presa da pálida fatalidade

De não mudar-me, me infiel renovo

Aos propósitos mudos

Morituros e infindos. 
A construção segue, aqui, como em boa parte das odes desse heterônimo, o modelo horaciano, da composição em doze versos, que alternam parelhas métricas de decassílabos e hexassílabos.

Observe-se que a imagem, sonora e visual, criada metricamente por esse modelo é, de per si, sugestiva da idéia de repetição cíclica, de eterno retorno das mesmas coisas, tal como é exposto já nos quatro primeiros versos: "No ciclo eterno das mudáveis coisas / Novo inverno após novo outono volve / À diferente terra / Com a mesma maneira".

Além da explícita menção ao “... ciclo eterno das mudáveis coisas”, é digno de nota, ainda nos mesmo quatro versos citados: o uso dos adjetivos "novo" e “diferente", num contexto que esvazia inteiramente o seu sentido próprio; o uso de um único verbo, em sua forma nominal ("volver") reforçando ainda mais o sentido de volta, retorno, das mesmas coisas e da mesma maneira.

Em boa medida, isso lembra Heráclito de Éfeso, o grande pensador présocrático, para quem a ordem do universo suporia, em meio a uma comunhão vital dos contrários, um fluxo constante e, ao mesmo tempo, o eterno retorno das mesmas coisas, ciclicamente: "Dispersa-se e reúne-se de novo; aproxima-se e se aparta"19; "É sempre uma só e mesma coisa a vida e a morte, o despertar e o dormir, a mocidade e a velhice. Quando se muda é aquilo; e aquilo, por sua vez, quando se muda, é isto, de novo". ${ }^{20}$

\footnotetext{
${ }^{19}$ HERÁCLITO. Frg. 91.

${ }^{20}$ HERÁCLITO. Frg. 88.
} 
Todavia, considerando-se o contexto geral das odes de Ricardo Reis, nem sempre essa tensão dialógica entre as idéias e o modo como são ditas se efetiva em termos de total harmonia. Pelo contrário, é comum verificar-se um certo descompasso entre

— de um lado, a linguagem clara, racionalizada, objetiva, metrificada segundo esquemas pré-estabelecidos;

— e do outro, a visão de mundo permeada de tensão, incerteza e afetada resignação.

Em meio a esse dialogismo, a essa contradição constante, penso eu, delineiase o significado da poesia Reis, ou seja, não só no nível das suas declarações explícitas, mas nas entrelinhas que denunciam a tensão entre o dito e o não dito: algumas vezes, como tensão entre o explícito e o subentendido, o qual, sendo externo à palavra, está à espera de ser explicitado; outras, entre o explícito e o implícito, que sendo interno à palavra, é inexaurível e só pode ser interpretado, não explicitado.

De costume, Ricardo Reis é aproximado de Epicuro, certamente com base nas constantes invocações ao nome e à doutrina desse pensador do Classicismo grego tardio, em vários de seus versos: "Meus irmãos em amarmos Epicuro" [337]; "Mas Epicuro melhor/ Me fala, com a sua cariciosa voz terrestre / Tendo para os deuses uma atitude também de deus,/ Sereno e vendo a vida /À distância a que está" [318]; "E vivamos assim,// Buscando o mínimo de dor ou gozo, / Bebendo a goles os instantes frescos,/ Translúcidos como água...”[317]. Entretanto, embora invoque Epicuro constantemente e mesmo o exalte como modelo e patrono espiritual de sua busca do fim 
supremo da ataraxia, não se pode dizer que Ricardo Reis conceda uma adesão irrestrita aos seus ensinamentos. Um exemplo pode ser visto nos versos que se seguem, onde o poeta se confessa tomado pelo temor da morte e do poder dos deuses sobre o destino humano, contrariando assim, frontalmente, as recomendações do filósofo helenista: "Lídia, a vida mais vil antes que a morte, / Que desconheço, quero" [375]; "Temo Lídia, o destino. Nada é certo./ Em qualquer hora pode suceder-nos/ O que nos tudo mude" [425]. Recomenda uma das máximas de Epicuro: "Habitua-te a pensar que a morte nada é para nós, visto que todo o mal e todo o bem se encontram na sensibilidade: e a morte é a privação da sensibilidade". ${ }^{21}$

De fato, é um engano pensar que a doutrina epicurista constitui, para Reis, uma direção unívoca. Sem falar na circunstância, já assinalada por alguns estudiosos, de que o Epicuro de Ricardo Reis passa, muitas vezes, pela mediação do poeta persa Omar Khayyam, cujo pensamento também está presente em várias de suas odes ${ }^{22}$, é bem perceptível a mesclagem com noções oriundas de outras filosofias do Helenismo. Penso, particularmente, no estoicismo, que o próprio Reis assume, a certa altura, como uma nota preeminente no delineamento de seu perfil:

Negue-me tudo a sorte, menos vê-la, ${ }^{23}$

Que eu, 'stóico sem dureza, Na sentença gravada do Destino

${ }^{21}$ EPICURO et al., 1973. p. 21.

${ }^{22}$ Sobre a presença do Ruba'iyat na obra pessoana, Cf: GARCEZ, Maria Helena Nery. O tabuleiro antigo; uma leitura do heterônimo Ricardo Reis. São Paulo: Editora da Universidade de São Paulo, 1990; e FEITOSA, Márcia Manir Miguel. Fernando Pessoa e Omar Khayyam: o Ruba'iyat na poesia portuguesa do século XX. São Paulo: Giordano, 1998.

${ }^{23}$ Edição crítica: "salvo vel-a”. Data: 21/02/1928. 
Quero gozar as letras.

Note-se que a expressão “...'stóico sem dureza ...” é apenas um modo poético de aludir ao que, em outro lugar, é referido como uma “... ética pagã, meio epicurista e meio estóica..."24, e que se deve entender como uma disposição bem peculiar, não propriamente de enfrentar com resignação os sofrimentos impostos pelo fatum, mas de desenvolver mecanismos de fuga, esteticizando-os e deles se distanciando como um simples contemplante e fruidor. De um lado, o cunho estóico é dado pela crença na inexorabilidade do "fatum" (fatalidade), "Na sentença gravada do Destino"; do outro, o toque epicurista se evidencia na disposição de apenas “... gozar as letras” dessa sentença, contemplativamente, acima das vicissitudes que ela possa reservar.

Naturalmente, há momentos, como por exemplo nos dois versos que finalizam a ode [368] — “Abdica e sê / Rei de ti mesmo!” —, em que se pode perceber uma inclinação ética bem definida, no caso, perfeitamente condizente com a máxima dos estóicos: "Suporta e abstém-te."

Todavia, no geral, um dos pontos que mais se salientam no paganismo de Ricardo Reis é a extrema flexibilidade do seu ecletismo religioso e filosófico: todos os deuses, seitas e doutrinas, religiosas e metafísicas, são aceitáveis, porque igualmente verdadeiros. Contrariamente a Caeiro, ele não vê os deuses como uma deformação do paganismo. Os deuses são úteis, pois servem “... para nos conduzirmos entre os homens" 25 ; são, ao mesmo tempo, reais e irreais — "São irreais porque não são

\footnotetext{
${ }^{24}$ PESSOA (REIS), 1995. p.131.

${ }^{25}$ PESSOA (REIS), 1995.p. 148.
} 
realidades, mas são reais porque são abstrações concretizadas. Uma abstração concretizada passa a ser pragmaticamente real; uma abstração não concretizada não é real mesmo pragmaticamente". ${ }^{26}$

Nesse panteão particular, o próprio Cristo tem lugar, mas como um deus a mais, que se acrescenta aos já existentes, sem qualquer prioridade:

O deus Pã não morreu, ${ }^{27}$ Cada campo que mostra Aos sorrisos de Apolo Os peitos nus de Ceres Cedo ou tarde vereis Por lá aparecer O deus Pã, o imortal.

Não matou outros deuses O triste deus cristão.

Cristo é um deus a mais, Talvez um que faltava. Pã continua a dar Os sons da sua flauta Aos ouvidos de Ceres Recumbente nos campos. ${ }^{28}$

Os deuses são os mesmos, Sempre claros e calmos, Cheios de eternidade E desprezo por nós, Trazendo o dia e a noite E as colheitas douradas Sem ser para nos dar $\mathrm{O}$ dia e a noite e o trigo Mas por outro e divino Propósito casual.

\footnotetext{
${ }^{26}$ PESSOA (REIS), 1995.p. 148.

${ }^{27}$ Na edição crítica, de Luís Fagundes Duarte, este primeiro verso tem ponto final.

${ }^{28}$ Na mesma edição crítica já citada, esta estrofe se divide em duas de quatro versos cada.
} 
O nivelamento das divindades pagãs e cristãs é aqui indicado não só pelos enunciados, mas subliminarmente pelas iniciais minúsculas em todas as referências (“deus", “deuses”). A segunda estrofe, sobretudo, não apenas nivela Cristo e o cristianismo com as outras seitas e religiões, mas diminui o seu valor, por exemplo, qualificando-o pelo adjetivo "triste", de certo alusivo à sua condição de "Crucificado" e à sua posição de mediador entre o divino e o humano. No quarto verso desta estrofe, o “Talvez" inicial acentua o caráter incerto e conjectural das afirmações sobre a importância e o significado do Cristo. A terceira e última estrofe, enfatizando a total indiferença dos deuses quanto ao destino e as necessidades dos homens, contrapõe-se diretamente à concepção cristã de Deus como sinônimo de bondade e compaixão.

Na verdade, a atitude de Ricardo Reis para com os deuses é bem flutuante. Às vezes, os cultua, defendendo mesmo uma visão do mundo como regido por instâncias superiores e desconhecidas, às quais o destino humano se encontra inteiramente submetido - "Só esta liberdade nos concedem / Os deuses: submetermo-nos / Ao seu domínio por vontade nossa.” [326]. Outras vezes, sobretudo em odes mais tardias, deixa-se tomar por um notório ceticismo, não propriamente negando os deuses, mas não mais os exaltando com a mesma firmeza inicial.

Isto pode ser visto, por exemplo, nas duas odes abaixo, a primeira datada de 1914, e a segunda, de 1935:

Anjos ou deuses ${ }^{29}$, sempre nós tivemos, A visão perturbada ${ }^{30}$ de que acima

${ }^{29} \mathrm{Na}$ mesma edição crítica já citada: De anjos ou deuses ... 
De nós e compelindo-nos

Agem outras presenças.

Como acima dos gados que há nos campos

O nosso esforço, que eles não compreendem,

Os coage e obriga

E eles não nos percebem,

Nossa vontade e o nosso pensamento ${ }^{31}$

São as mãos pelas quais outros nos guiam

Para onde eles querem

E nós não desejamos. ${ }^{32}$

[435]

Meu gesto que destrói $i^{33}$

A mole das formigas. ${ }^{34}$

Tomá-lo-ão elas por de um ser divino;

Mas eu não sou divino para mim.

Assim talvez os deuses

Para si o não sejam,

E só de serem do que nós maiores

Tirem o serem deuses para nós.

Seja qual for o certo, Mesmo para com esses

Que cremos serem deuses, não sejamos

Inteiros numa fé talvez sem causa. ${ }^{35}$

Na primeira ode, note-se que, paralelamente à crença num destino guiado das

\footnotetext{
${ }^{30} \mathrm{Na}$ mesma edição crítica já citada: confiada

${ }^{31} \mathrm{Na}$ mesma edição crítica já citada: Nossa vontade e nosso pensamento

${ }^{32} \mathrm{Na}$ mesma edição crítica já citada: Que nós o desejemos.

${ }^{33}$ Na mesma edição crítica já citada: destrue

${ }^{34} \mathrm{Na}$ mesma edição crítica já citada: há um ponto final neste verso.

${ }^{35}$ Na mesma edição crítica já citada: sem deuses
} 
alturas por mãos invisíveis, o poeta insere idéias sobre a hierarquia do mundo espiritual, que, como observa Georg Rudolf Lind, exibem forte matiz teosófico. ${ }^{36}$

Já na segunda, embora persistam elementos de cunho esotérico, devemos concordar com Maria Helena Nery Garcez em que

\begin{abstract}
“... tudo fica posto sob o signo da dúvida. Mais do que uma decidida adesão à visão esotérica, o que existe é uma atitude de cética reserva, uma hipótese a respeito de um mundo superior ao humano, um possível mundo sobre o qual Reis não possui certezas e ao qual, por isso, não adere com firmeza. A fé não encontra suporte em nenhum fundamento. Nesta ode estamos muito longe daquela ostensiva defesa do paganismo encontrável principalmente na primeira metade do Livro das Odes de Ricardo Reis. Reencontramos o agnosticismo." ${ }^{37}$
\end{abstract}

O ecletismo de Ricardo Reis é a tal ponto notório e recorrente, que se pode aplicar, também às suas odes (tanto quanto aos poemas Alberto Caeiro), o diagnóstico da falta de unidade filosófica.

Observe-se uma ode inicial, onde Ricardo Reis entabula um diálogo com o Mestre Alberto Caeiro, expondo-lhe a sua visão pessoal sobre como alcançar o estado de suposta placidez e bem-aventurança, por ele pregado:

Mestre, são plácidas

Todas as horas

Que nós perdemos, Se no perdê-las, Qual numa jarra, Nós pomos flores.

Não há tristezas

\footnotetext{
${ }^{36}$ LIND, 1970. p. 141.

${ }^{37}$ GARCEZ, 1990. p.76.
} 
Nem alegrias

Na nossa vida.

Assim saibamos,

Sábios incautos,

Não a viver,

Mas decorrê-la,

Tranqüilos, plácidos,

Tendo as crianças

Por nossas mestras,

E os olhos cheios

De Natureza ...

À beira-rio,

À beira-estrada,

Conforme calha,

Sempre no mesmo

Leve descanso

De estar vivendo.

O tempo ${ }^{38}$ passa,

Não nos diz nada.

Envelhecemos.

Saibamos, quase

Maliciosos,

Sentir-nos ir.

Não vale a pena

Fazer um gesto.

Não se resiste

Ao deus atroz

Que os próprios filhos

Devora sempre.

Colhamos flores.

Molhemos leves

As nossas mãos

Nos rios calmos,

Para aprendermos

Calma também.

Girassóis sempre

Fitando o sol,

${ }^{38}$ Na mesma edição crítica já citada: Tempo 
Da vida iremos

Tranqüilos, tendo

Nem o remorso

De ter vivido.

É bem notório, desde a primeira estrofe, o caráter "negativo" dessa visão da existência humana como uma sucessão de "perdas", de "subtrações". Nesse sentido, repare-se no uso consecutivo do verbo "perder", em dois lugares onde, de costume, se usaria o verbo "passar": “Todas as horas / Que nós perdemos / Se no perdê-las ... ”. Nas estrofes seguintes, mantém-se a mesma disposição disposição "negativa": face à falta de sentido da nossa vida, a solução é "Não a viver // Mas decorrê-la, / Tranqüilos, plácidos ...”. Tudo se resume em passar a vida ludicamente, “À beira-rio, / À beira-estrada, / Conforme calha", enfim, sem nos envolvermos e sem visarmos qualquer objetivo. $\mathrm{O}$ conceito de tempo é igualmente negativo, visto como um curso inexorável e destruidor, o que é reforçado pela construção lacônica dos três versos que o expõem: "O tempo passa, / Não nos diz nada. / Envelhecemos.”

À parte o fato de que, em certo sentido, esse tom negativista do discurso de Ricardo Reis contrasta com a serenidade da ataraxia pregada por Epicuro, é digna de nota a tensão semântica instituída pela contraposição desses dois planos —o das exortações à indiferença, ao cultivo do gozo insciente do momento e o do sentimento negativo que isto provoca.

Essa tensão semântica é recriada, no plano estilístico, pela tensão rítmica entre o fluxo ligeiro e contínuo das estrofes - sempre de seis versos tetrassilábicos e algumas vezes encadeadas com a estrofe seguinte - e a dupla leitura possível (a acentuação interna é irregular, podendo recair tanto na primeira quanto na segunda 
sílaba). Isto gera ambigüidade comunicativa: paralelamente à indiferença que o eu poético quer demonstrar diante do curso inexorável do destino, insinua-se, aqui e ali, uma mal disfarçada inquietação.

Em outras odes, a tensão interpretativa se manifesta através de vários recursos. Por exemplo, através de metáforas como a do "rio", da "água", inevitavelmente evocativas de Heráclito ${ }^{39}$ e seus aforismos sobre o devir constante do universo e a transitoriedade da vida terrena. De certo, não há uma referência direta a Heráclito, no discurso de Reis, mas a simples evocação das metáforas sibilinas, que valeram a esse filósofo o epíteto de "o obscuro", já é suficiente para turvar a suposta transparência e placidez das odes Reis, deixando implícito no próprio tecido poético a tensão que se instala entre o seu ideal estóico-epicurista de harmonia e estabilidade e o fluxo inquieto e inexorável do rio da vida, "à beira” do qual, ele tenta se manter, para conseguir, quem sabe, uma placidez qualquer: "Vem sentar-te comigo, Lídia, à beira do rio./ Sossegadamente fitemos o seu curso e aprendamos / Que a vida passa..."; "Quer gozemos, quer não gozemos, passamos como o rio" [315].

De fato, são vários e bem numerosos os aspectos estilísticos que instauram a tensão comunicativa no seio mesmo desse suposto epicurismo, e que confirmam tratarse, afinal, de “... de um Epicuro à moda da casa ...”. 40

\footnotetext{
${ }^{39}$ Essas metáforas têm suscitado interpretações psicanalíticas e, como foi comentado no capítulo 1, há quem aí veja uma correspondência profunda com o sentimento de Pessoa por sua mãe: a água alimenta e embala, "... é o leite da terra inteira..." e "... o único elemento que tem a propriedade de ritmadamente marcar um movimento que fala ao coração..." (PADRÃO, 1973. p.92-3).

${ }^{40}$ GARCEZ, 1990. p.83.
} 
A ode transcrita a seguir é mais um dos exemplos bem conseguidos da atitude de alheamento que caracteriza Ricardo Reis:

$[337]^{41}$

Ouvi contar que outrora, quando a Pérsia

Tinha não sei qual guerra,

Quando a invasão ardia na Cidade

$\mathrm{E}$ as mulheres gritavam,

Dois jogadores de xadrez jogavam

O seu jogo contínuo.

À sombra de ampla árvore fitavam

O tabuleiro antigo,

E, ao lado de cada um, esperando os seus

Momentos mais folgados,

Quando havia movido a pedra, e agora

Esperava o adversário,

Um púcaro com vinho refrescava

Sobriamente a sua sede. ${ }^{42}$

Ardiam as casas, saqueadas eram

As arcas e as paredes,

Violadas, as mulheres eram postas

Contra os muros caídos,

Traspassadas de lanças, as crianças

Eram sangue nas ruas ...

Mas onde estavam, perto da cidade,

E longe do seu ruído,

Os jogadores de xadrez jogavam

O jogo de xadrez.

Inda que nas mensagesn do ermo vento

Lhes viessem os gritos,

E, ao refletir, soubessem desde a alma ${ }^{43}$

Que por certo as mulheres

$\mathrm{E}$ as tenras filhas violadas eram

Nessa distância próxima,

Inda que, no momento que o pensavam,

Uma sombra ligeira

Lhes passasse na fronte alheada e vaga,

\footnotetext{
${ }^{41}$ Na edição crítica já citada: esta ode aparece com o título "Os jogadores de xadrez".

${ }^{42}$ Na edição crítica já citada: A sua sobria sede.

${ }^{43}$ Na edição crítica já citada: coubessem com acerto
} 
Breve seus olhos calmos

Volviam sua atenta confiança

Ao tabuleiro velho.

Quando o rei de marfim está em perigo,

Que importa a carne e o osso

Das irmãs e das mães e das crianças?

Quando a torre não cobre

A retirada da rainha branca,

$\mathrm{O}$ saque pouco importa.

E quando a mão confiada leva o xeque

Ao rei do adversário,

Pouco pesa na alma que lá longe

Estejam morrendo filhos.

Mesmo que, de repente, sobre o muro

Surja a sanhuda face

Dum guerreiro invasor, e breve deva

Em sangue ali cair

O jogador solene de xadrez,

O momento antes desse

(É ainda dado ao cálculo dum lance

Pra a efeito horas depois)

É ainda entregue ao jogo predileto

Dos grandes indif' rentes.

Caiam cidades, sofram povos, cesse

A liberdade e a vida. ${ }^{44}$

Os haveres tranqüilos e avitos

Ardam e que se arranquem,

Mas quando a guerra os jogos interrompa,

Esteja o rei sem xeque,

E o marfim peão mais avançado

Pronto a comprar a torre.

Meus irmão em amarmos Epicuro

E o entendermos mais

De acordo com nós-próprios que com ele,

Aprendamos na história

Dos calmos jogadores de xadrez

Como passar a vida.

Tudo o que é sério pouco nos importe,

$\mathrm{O}$ grave pouco pese,

${ }^{44} \mathrm{Na}$ edição crítica já citada: vírgula no final deste verso. 
O natural impulso dos instintos

Que ceda ao inútil gozo

(Sob a sombra tranquiila do arvoredo)

De jogar um bom jogo.

O que levamos desta vida inútil

Tanto vale se é

A glória, a fama, o amor, a ciência, a vida,

Como se fosse apenas

A memória de um jogo bem jogado

E uma partida ganha

A um jogador melhor.

A glória pesa como um fardo rico,

A fama como a febre,

O amor cansa, porque é a sério e busca

A ciência nunca encontra,

E a vida passa e dói porque o conhece ...

O jogo de xadrez

Prende a alma toda, mas, perdido, pouco

Pesa, pois não é nada.

Ah! Sob as sombras que sem qu'erer nos amam,

Com um púcaro de vinho

Ao lado, e atentos só à inútil faina

Do jogo do xadrez

Mesmo que o jogo seja apenas sonho

E não haja parceiro,

Imitemos os persas desta história,

E, enquanto lá fora, ${ }^{45}$

Ou perto ou longe, a guerra e a pátria e a vida

Chamam por nós, deixemos

Que em vão nos chamem, cada um de nós

Sob as sombras amigas

Sonhando, ele os parceiros, e o xadrez

A sua indiferença.

Evidencia-se, aqui, um duplo distanciamento da cena de ação, não só pelo fato de tratar-se de um discurso narrativo, que se vale predominantemente da terceira pessoa, do singular e do plural, mas também pelo fato de que as duas personagens

${ }^{45}$ Na edição crítica já citada: “... lá por fora,”. 
principais, os jogadores de xadrez, se apresentam como metáforas da condição paradoxal do homem no jogo da vida: jogador e espectador, ao mesmo tempo.

O jogo, não apenas de xadrez, mas o jogo de modo geral, é um espaço lúdico, dotado de uma essência própria, que o torna independente até mesmo dos jogadores que nele se envolvem. Como recorda Gadamer, é o próprio jogo que se joga através dos jogadores, impondo-se, portanto, como o verdadeiro sujeito da ação por eles praticada. ${ }^{46}$ Em sentido semelhante, acrescenta Gianni Vattimo:

\begin{abstract}
"L'essenza del gioco si realizza pienamente proprio là dove è piú chiaro che i giocatori 'sono in gioco', cioè appartengono a una realtà che li trascende $\mathrm{e}$ si realizza in essi e nel loro giocare. Il gioco, con le sue regole, è una totalità di significato che supera i giocatori stessi. ${ }^{, 47}$
\end{abstract}

Isto é sobremodo expressivo no jogo de xadrez, onde, como observa Maria Helena Nery Garcez, o espaço lúdico se caracteriza por uma situação de peculiar não envolvimento: tratando-se de um jogo mental, os jogadores não se introduzem de corpo inteiro, pelo contrário, “... situam-se à margem do tabuleiro. Nem estão longe nem dentro do espaço do jogo; [...] poderíamos dizer que os jogadores estão à beiratabuleiro. ${ }^{48}$ Dito em outros termos, eles ocupam uma dupla posição, qual seja, a de

\footnotetext{
${ }^{46}$ Cf. GADAMER, 1977. p.149-50.

${ }^{47}$ VATTIMO, 1985. p.174. T. da A.: "A essência do jogo se realiza plenamente justo onde é mais claro que os jogadores 'estão em jogo', isto é, pertencendo a uma realidade que os transcende e se realiza neles e no seu jogar. O jogo, com suas regras, é uma totalidade de significado que supera os próprios jogadores."

${ }^{48}$ GARCEZ, 1990. p.32.
} 
jogadores e, ao mesmo tempo, espectadores, ou quase espectadores, como diria Gadamer. $^{49}$

Lembrando que o jogo é dotado de essência própria, impõe-se aos jogadores um estado mental de voluntária suspensão das referências finais que determinam a existência ativa normal. Nesse sentido, escreve o poeta que "O jogo do xadrez / Prende a alma toda ...”. Mas, por outro lado, sendo um espaço lúdico, que se insere como um recorte em meio à existência ativa normal, esse mesmo jogo,“... perdido, pouco / Pesa, pois não é nada”, quer dizer, não inflige uma perda verdadeira, um sofrimento real.

Como se vê, tudo isso parece bem coerente com o ecletismo da receita de vida de Ricardo Reis (aliás, ele próprio alude, na oitava estrofe deste mesmo poema, ao caráter pouco ortodoxo do seu epicurismo: "Meus irmãos em amarmos Epicuro / E o entendermos mais / De acordo com nós-próprios que com ele ...”).

Lembrando que Epicuro é o introdutor da noção de acaso na história da filosofia, não deixa de ser sugestivo que, duas estrofes à frente, Ricardo Reis insira uma crucial ruptura no seu fatalismo quase estóico e nele introduza a possibilidade do acaso, a saber, o inesperado da “... partida ganha / A um jogador melhor."

Como assinala Maria Helena Nery Garcez, “O jogador pior vencer consiste numa ruptura da previsibilidade" ${ }^{50}$ E essa ruptura não se dá apenas do ponto de vista semântico, mas, também, do ponto de vista formal, na medida em que o modo de

${ }^{49}$ GADAMER, 1977. p.149-50.

${ }^{50}$ GARCEZ, 1990. p.27. 
estruturação dessa estrofe rompe com o esquema de previsibilidade construtiva até então prevalecente: introduz uma estrofe com número ímpar de versos (sete) e desobediente ao esquema de alternância de metros patente nas outras onze estrofes (em lugar da alternância de um decassílabo e um hexassílabo, a estrofe emparelha dois hexassílabos, nos dois versos finais). ${ }^{51}$

Ainda segundo Maria Helena Nery Garcez, vale assinalar mais um outro dado que, nesta ode [337], desmente a postura de apatia pretendida por Ricardo Reis: a dimensão crítica, e por que não dizer paródica, dessa ode em relação aos valores morais que a ode pindárica, em cujo modelo irregular ela se inspira, tradicionalmente exalta: ela “... não termina com exortações morais previsíveis e tradicionais, mas com exortações que precisamente agridem e subvertem essa moral" ${ }^{152}$.

Esse tom provocativo e contestativo destoa da postura de deliberado não envolvimento, preconizada pelo heterônimo das odes.

Com o passar dos anos, cresce a tensão dentro das odes-Reis, a ponto de transformar o seu discurso tendencialmente monológico, a sua forma bem metrificada, bem comportada, num flagrante disfarce para o conflito interior que o atravessa e o transforma num ser plural, polifônico.

Se recordo quem fui, outrem me vejo, E o passado é o presente na lembrança. ${ }^{53}$

\footnotetext{
${ }^{51}$ GARCEZ, 1990. p.27-9.

52 GARCEZ, 1990. p.28.

53 Edição Crítica: "No passado, presente da lembrança."
} 
Quem fui é alguém que amo ${ }^{54}$

Porém somente em sonho.

E a saudade que me aflige a mente

Não é de mim nem do passado visto,

Senão de quem habito

Por trás dos olhos cegos.

Nada, senão o instante, me conhece.

Minha mesma lembrança é nada, e sinto

Que quem sou e quem fui

São sonhos diferentes.

Mais uma vez, a construção segue o modelo horaciano de composição em doze versos, alternando parelhas métricas de decassílabos e hexassílabos. Além da imagem, sonora e visual, criada metricamente por esse modelo, outros recursos estilísticos tentam concretizar, na própria forma poética, a complexidade da pretendida aproximação do presente com o passado.

A tensão interpretativa se intensifica com a lembrança da vivência antiga e a dificuldade de uma avaliação presente sobre esse tempo passado. Tudo fica colocado sob o signo do sonho: o eu presente e o eu passado, relegando-se o eu real a uma espécie de interstício entre esses dois sonhos: "E a saudade que me aflige a mente / Não é de mim nem do passado visto, / Senão de quem habito / Por trás dos olhos cegos."

Avançando no exame do desenvolvimento subsequente da trajetória poética de Ricardo Reis, pode-se observar que, a certa altura, ele põe de lado a máscara do autocontrole, a utopia da placidez total, e passa a falar abertamente da polifonia que o constitui internamente, a ele e a todos nós:

Vivem em nós inúmeros;

Se penso ou sinto, ignoro

\footnotetext{
${ }^{54}$ Edição Crítica: "Sinto-me como em sonho".
} 
Quem é que pensa ou sente.

Sou somente o lugar

Onde se sente ou pensa.

Tenho mais almas que uma.

Há mais eus do que eu mesmo.

Existo todavia

Indiferente a todos.

Faço-os calar: eu falo.

Os impulsos cruzados

Do que sinto ou não sinto

Disputam em quem sou.

Ignoro-os. Nada ditam

A quem me sei: eu 'screvo.

Observe-se que, coerentemente com a afirmação inicial — "Vivem em nós inúmeros" - , a composição dos versos exibe uma expressiva variação de vozes. A esse verso inicial, com o verbo na primeira pessoa do plural, segue-se o uso da primeira pessoa do singular, conferindo ao discurso um cunho pessoal. A propósito dos verbos utilizados na primeira estrofe, é significativo que, quando aparecem na primeira pessoa do singular, o seu sentido é de desconhecimento, de não saber ("Se penso ou sinto, ignoro / Quem é que pensa ou sente").

Na segunda estrofe, nova variação: o segundo verso usa o verbo haver de modo impessoal, na terceira pessoa do singular; os demais prosseguem com a primeira pessoa do singular.

$\mathrm{Na}$ terceira estrofe, os três primeiros versos se interligam por um "enjambement": "Os impulsos cruzados / Do que sinto ou não sinto / Disputam em quem sou". Observe-se que o primeiro verso (sem verbo) e o terceiro (com o verbo na terceira pessoa do plural) constituem a oração principal do período, sendo que a função de 
sujeito cabe ao primeiro verso. A primeira pessoa do singular é relegada a um posto secundário (dentro da oração subordinada, que constitui o segundo verso, e dentro da terceira, com função complementar).

Embora fique em aberto a real natureza das instâncias que detêm o controle desse concerto a várias vozes, é notória a sua sintonia com a idéia do descentramento do eu em relação à condução do seu discurso, comum ao contexto novecentista de "crise do sujeito", ou seja, a idéia de um dialogismo não intencional, representado pelas vozes que habitam o sujeito e que sempre se manifestam em seu discurso. Repare-se que a afirmação "Sou somente o lugar / Onde se sente ou pensa" exibe uma sugestiva consonância com a idéia as despersonalização poética, difundida, desde fins do século XIX, em especial, por Rimbaud. Estou a pensar no célebre dito do poeta francês: "É errado dizer Eu penso; dever-se-ia dizer estou sendo pensado". ${ }^{55}$ Pode-se evocar, igualmente, uma sintonia com o vocabulário psicanalítico introduzido por Sigmund Freud, para falar do descentramento do Ego em relação a si mesmo.

Não quero recordar nem conhecer-me.

Somos demais ${ }^{56}$ se olharmos em quem somos.

Ignorar que vivemos

Cumpre bastante a vida.

Tanto quanto vivemos, vive a hora

Em que vivemos, igualmente morta

Quando passa conosco,

Que passamos com ela.

Se sabê-lo não serve de sabê-lo

(Pois sem poder que vale conhecermos? ${ }^{57}$

\footnotetext{
${ }^{55}$ RIMBAUD apud Fischer, 1983. p.106.

${ }^{56}$ Edição Crítica: "Somos de mais se ..."
} 
Melhor vida é a vida

Que dura sem medir-se.

De uma forma ou de outra, o certo é que, embora se trate de uma personagem calcada no utópico ideal helênico da ataraxia, a inquietação latente nas constantes entrelinhas do seu discurso poético compromete inteiramente esse escopo, impedindo que ele atinja o seu esperável adensamento.

Finalizando, cumpre observar que, mesmo revelando momentos de dúvida, inquietude e mesmo de notório ceticismo (como foi comentado a propósito das odes [334] e [435], Ricardo Reis não chega ao ponto de pregar uma suspensão do juízo. Pelo contrário, usa e abusa do modo imperativo para a formulação de seus axiomas morais. Mesmo quanto à zétesis, sua atitude é tão dúbia quanto a de Alberto Caeiro: de um lado, proclama, em diversas odes, que não quer saber nada além do que tem diante dos olhos; do outro faz perguntas incansavelmente, como se, mesmo sem pretender estabelecer algum tipo de verdade, sua mente se mantivesse numa atitude fundamentalmente inquisitiva. A proximidade com o ponto de vista do ceticismo insinua-se a esta altura.

${ }^{57}$ Edição Crítica: vírgula depois do parênteses. 


\section{3 Álvaro de Campos}

A produção poética atribuída a Álvaro de Campos, o terceiro poetapersonagem da "coterie" poética inventada por Fernando Pessoa, apresenta tendências diversas, que se alternam e se cruzam continuamente, impedindo, por um lado, uma divisão em fases definidas, por outro, uma classificação estilística ou ideológica unívoca.

No entanto, é possível apontar diferenças significativas entre os poemas anteriores e posteriores ao seu "encontro" com Alberto Caeiro, caracterizando-se os primeiros por uma linguagem de acento decadentista, obediente a convenções estilísticas e formas poéticas pré-fixadas. Para exemplificar, cito o soneto abaixo:

Quando olho para mim não me percebo.

Tenho tanto a mania de sentir.

Que me extravio às vezes ao sair

Das próprias sensações que eu recebo.

$\mathrm{O}$ ar que respiro, este licor que bebo,

Pertencem ao meu modo de existir,

E eu nunca sei como hei de concluir

As sensações que a meu pesar concebo.

Nem nunca, propriamente reparei,

Se na verdade sinto o que sinto. Eu

Serei tal qual pareço em mim? Serei

Tal qual me julgo verdadeiramente?

Mesmo ante as sensações sou um pouco ateu,

Nem sei bem se sou eu quem em mim sente.

Ressalta-se, neste soneto, datado de $1913^{58}$, a unidade temática, o metro em decassílabos, as rimas obedientes a um esquema predefinido: nos dois quartetos, o

58 Note-se que "Opiário", também de acento decadentista, data de alguns meses mais tarde. 
modelo seguido é ABBA, sendo as rimas emparelhadas agudas, toantes e constituídas por verbos no infinitivo (sentir e sair; existir e concluir) e as interpoladas, por contraste, graves, consoantes e constituídas por verbos na primeira pessoa do singular do presente do indicativo (percebo e recebo; bebo e concebo); nos dois tercetos, os modelos são, respectivamente, CDC e EDE. O “enjambement", que liga os dois últimos versos do primeiro terceto ao primeiro verso do segundo, cria tensão interpretativa, na medida em que confere maior realce às duas interrogações que aí se formulam.

A partir da suposta influência do "Mestre" Alberto Caeiro, os poemasCampos sofrem uma mudança notória não só no que se fere à explosão sensorialista que neles se verifica, mas também no que diz respeito à ruptura com as formas pré-fixadas: adota, então, a assimetria, o verso livre, o ritmo imprevisível, como princípios poéticos privilegiados. Nesse sentido, pode-se qualificá-lo como o protótipo do poeta "não aristotélico",59, que tudo converte “... em substância de sensibilidade..."60, recusando contenções de qualquer ordem, racional ou convencional, de modo a tornar-se um “... foco emissor abstrato sensível ..."61, capaz de desenvolver em si mesmo todas as espécies de sensações e alcançar comunicabilidade universal.

Em consonância com esse ideal programático, ganha relevo a faceta talvez mais conhecida de Álvaro de Campos, que é a de poeta "futurista". Sobre a propriedade ou impropriedade desse epíteto, muito já se discutiu, e inclusive o próprio Campos já se

\footnotetext{
${ }^{59}$ Como se sabe, Fernando Pessoa pretendia lançar, sob o nome de Álvaro de Campos, uma "Estética não-aristotélica", baseada na sensibilidade e não no conceito racionalista de beleza. PESSOA (CAMPOS), 1995. p.245.

${ }^{60}$ PESSOA (CAMPOS), 1995. p.244.

${ }^{61}$ PESSOA (CAMPOS), 1995. p.244.
} 
manifestou em sentido de franca desaprovação ${ }^{62}$. Todavia, sendo uma qualificação ainda recorrente na literatura crítica sobre esse poeta-personagem, é pertinente dizer alguma coisa a respeito.

Dentre as produções poéticas que motivam a qualificação de Álvaro de Campos como heterônimo "futurista", está a "Ode Triunfal". Por ser uma composição muito longa, transcrevo apenas as cinco estrofes iniciais, que passo, em seguida a comentar:

À dolorosa luz das grandes lâmpadas elétricas da fábrica

Tenho febre e escrevo.

Escrevo rangendo os dentes, fera para a beleza disto,

Para a beleza disto totalmente desconhecida dos antigos.

Ó rodas, ó engrenagens, r-r-r-r-r-r eterno!

Forte espasmo retido dos maquinismos em fúria!

Em fúria fora e dentro de mim,

Por todos os meus nervos dissecados fora

Por todas as papilas fora de tudo com que eu sinto!

Tenho os lábios secos, ó grandes ruídos modernos,

De vos ouvir demasiadamente de perto,

E arde-me a cabeça de vos querer cantar com um excesso

De expressão de todas as minhas sensações,

Com um excesso contemporâneo de vós, ó máquinas!

Em febre e olhando os motores como a uma Natureza tropical -

Grandes trópicos humanos de ferro e fogo e força -

Canto, e canto o presente, e também o passado e o futuro,

Porque o presente é todo o passado e todo o futuro

E há Platão e Virgílio dentro das máquinas e das luzes elétricas

Só porque houve outrora e foram humanos Virgílio e Platão,

E pedaços do Alexandre Magno do século talvez cinqüenta,

Átomos que hão de ir ter febre para o cérebro do Ésquilo do século cem,

Andam por estas correias de transmissão e por estes êmbolos e por estes volantes,

Rugindo, rangendo, ciciando, estrugindo, ferreando,

Fazendo-me um excesso de carícias ao corpo numa só carícia à alma.

${ }^{62}$ É sabido que Álvaro de Campos repudia o seu enquadramento em qualquer corrente literária — "Eu, de resto, nem sou interseccionista (ou paúlico) nem futurista. Sou eu, apenas eu, preocupado apenas comigo e com as minhas sensações". PESSOA (CAMPOS), 1995. p.154. 
Ah, poder exprimir-me todo como um motor se exprime!

Ser completo como uma máquina!

Poder ir na vida triunfante como um automóvel último-modelo!

Poder ao menos penetrar-me fisicamente de tudo isto,

Rasgar-me todo, abrir-me completamente, tornar-me passento

A todos os perfumes de óleos e calores e carvões

Desta flora estupenda, negra, artificial e insaciável!

Fraternidade com todas as dinâmicas!

Promíscua fúria de ser parte-agente

Do rodar férreo e cosmopolita

Dos comboios estrênuos,

Da faina transportadora-de-cargas dos navios,

Do giro lúbrico e lento dos guindastes,

Do tumulto disciplinado das fábricas,

E do quase-silêncio ciciante e monótono das correias de transmissão!

$(\ldots)$

Embora alguns estudiosos vejam, nos dois versos de abertura, uma exaltação futurista da civilização industrial, ${ }^{63}$ chamo a atenção para o adjetivo "dolorosa" e para a sensação de "febre", mencionada no segundo verso, elementos que já antecipam uma disposição bem distante de uma apologia do futurismo.

É bem verdade que, na seqüência das estrofes, o leitor vai se deparar com um discurso que evoca imagens, ruídos, ritmos e cheiros próprios do cotidiano de um porto marítimo dentro de uma sociedade industrial, e, além disso, com realces tipográficos bem típicos da poética futurista: "Ó rodas, ó engrenagens, r-r-r-r-r-r eterno!”; “Hup-lá, hup-lá, hup-lá-hô, hup-lá!/ Hé-lá! He-hô Ho-o-o-o-o!/ Z-z-Z-Z-Z-Z-ZZ-Z-Z-Z-Z!”.

Mas, a bem se ver, a afinidade com o Futurismo não vai muito adiante, destacando-se elementos de fato incompatíveis com as posições desse movimento.

${ }^{63}$ Cf. LIND, 1970. p.182. 
Não se percebe, por exemplo, aquela hostilidade em relação ao passado, à tradição cultural da humanidade, tão característica dos postulados defendidos por Marinetti. ${ }^{64} \mathrm{O}$ próprio título, "Ode Triunfal" se mostra como um dispositivo intertextual, na medida em que resgata uma forma poética característica da Antigüidade, sinalizando, de per si, uma disposição acolhedora em relação ao passado. Na seqüência das estrofes, vai se salientando uma verdadeira fusão dos momentos culturais diversos em sínteses sucessivas através da história. Veja-se, por exemplo, este trecho extraído da terceira estrofe, já citada acima:

(...)

Canto, e canto o presente, e também o passado e o futuro,

Porque o presente é todo o passado e todo o futuro,

E há Platão e Virgílio dentro das máquinas e das luzes elétricas

Só porque houve outrora e foram humanos Virgílio e Platão,

E pedaços do Alexandre Magno do século talvez cinqüenta,

Átomos que hão de ir ter febre para o cérebro do Ésquilo do século cem,

Andam por estas correias de transmissão e por estes êmbolos e por estes volantes

(...)

Como se pode notar, o que aqui se salienta não é apenas a presença, no momento presente, dos germes dos séculos futuros, mas a inserção desse presente numa longa tradição, num saber cultural acumulado por séculos e séculos. Esse enfoque, permeado de sugestões hegelianas, confirma-se mais para o final da ode, nos dois versos que reiteram: "Eia todo o passado dentro do presente! / Eia todo o futuro dentro de nós! Eia!".

Além dessa valorização do histórico, é de se notar a emotividade que domina esse discurso, cujo foco, afinal, não são os maquinismos, mas os sentimentos

${ }^{64}$ Diz o postulado básico do Futurismo: "Distruggere il passato, tutto quanto il passato: esempi, memorie, tradizioni, per lasciare libero il campo all'arte futura." (Transcrito segundo citação feita por LIND, 1970. p.179). 
excessivos e as sensações exacerbadas que os mesmos provocam. $\mathrm{O}$ eu poético não simplesmente descreve suas sensações, mas dialoga com elas, em certos momentos. Personaliza-as através de uma respeitosa segunda pessoa do plural ("Tenho os lábios secos, ó grandes ruídos modernos, / De vos ouvir demasiadamente de perto"); fala do seu transpassamento por todas elas ("Forte espasmo retido dos maquinismos em fúria! / Em fúria fora e dentro de mim ...") e enfatiza tudo isso, através de recursos estilísticos como as longas seqüências de anáforas — "Por todos os ... / Por todas as ..."; "Promíscua fúria de ser parte-agente / Do rodar férreo e cosmopolita / Dos comboios estrênuos, / Da faina transportadora-de-cargas dos navios, / Do giro lúbrico e lento dos guindastes, / Do tumulto disciplinado das fábricas, / E do quase-silêncio ciciante e monótono das correias de transmissão!".

Por si sós, os aspectos acima ressaltados são bastantes para sinalizar o distanciamento da "Ode Triunfal" em relação à tônica objetivista da poética futurista ${ }^{65}$, permitindo mesmo qualificar o seu autor, não como “... o cantor da Máquina, da Electricidade ...", mas, mais precisamente, como “... o seu des-cantor ..."66.

Mas há ainda outros aspectos que debilitam o seu suposto "futurismo" e justificam perfeitamente a ponderação de que se trata, mais propriamente de uma "Ode Triunfal" às avessas, ou melhor, de uma "pseudo-Ode Triunfal"67.

Em particular, quero observar que, sendo Álvaro de Campos, de um lado, um engenheiro naval, imerso na atmosfera inóspita da sua vida profissional, e do outro,

\footnotetext{
${ }^{65}$ Veja-se, a propósito, as observações do próprio PESSOA-CAMPOS, 1995. p.153.

${ }^{66}$ LOURENÇO, 1973. p.96.

${ }^{67}$ LOURENÇO, 1973. p.96.
} 
um poeta do tipo "não-aristotélico", cujo princípio programático precípuo é a experiência de todas as espécies de sensações, sobre coisas diversas e sobre a mesma coisa, sua saída não poderia ser outra: dispor-se a “... sentir a cidade como sente o campo, o normal como o anormal, o que é mau como o que é bom, o mórbido como o saudável"68

Naturalmente, o impacto desse procedimento é bem outro que a tranqüilidade singela pregada pelo Mestre Alberto Caeiro, em seu elogio constante das coisas naturais e da vida campesina: para Álvaro de Campos, não resta senão sentir a paisagem citadina como se fosse uma paisagem campesina, olha-la “... como uma Natureza tropical". Ora, isto implica entrar em relação íntima com "rodas", “engrenagens", “correias de transmissão", "êmbolos", "volantes", "guindastes", "motores", "maquinismos em fúria", enfim, com coisas que só podem gerar um sentimento mórbido de transpassamento maquinizante: "Ah, poder exprimir-me todo como um motor se exprime! / Ser completo como uma máquina!". A impossibilidade desse desejo, já realçada pela interjeição inicial, é enfatizada pelo uso do verbo "poder" no modo infinitivo e pela anáfora que o repete no início dois versos subsequentes: "Poder ir ..." / "Poder ao menos ...".

Outro traço que torna problemática a designação de Álvaro de Campos como "futurista", e que se torna bem perceptível, quando se passa à leitura de outras odes e poemas de sua autoria, é a recorrência de alusões de cunho metafísico. Se bem que seus versos exibam, quase sempre, um acento marcantemente anti-metafísico e antisimbolista — "Tirem-me daqui a metafísica! / Não me apregoem sistemas completos

${ }^{68}$ PESSOA, 1995. p.130-1. 
..." [450]; "Símbolos? Estou farto de símbolos.../ [...] Símbolos? Não quero símbolos..." [498]; "Símbolos. Tudo símbolos... / Se calhar, tudo é símbolos... / Serás tu um símbolo também? [485] — são encontráveis passagens indicativas de uma preocupação metafísica, sob vários aspectos, coincidente com a de Fernando Pessoa ortônimo. Penso especialmente na sintonia das metáforas centrais de "Ode Marítima" — "Grande Cais Anterior”, "Cais Absoluto”, “... outra espécie de porto”, “... fora do Espaço e do Tempo" [442] — com as usadas por Fernando Pessoa ortônimo em versos como os que se seguem: "O porto sempre por achar" [22]; "Atravessa esta paisagem o meu sonho dum porto infinito..."; "O porto que sonho é sombrio e pálido", "Mas no meu espírito o sol deste dia é porto sombrio", "E a sombra duma nau mais antiga que o porto que passa", "Entre o meu sonho do porto e o meu ver esta paisagem" [59.1]; "Para o Porto todos os portos", "A Enseada todas as enseadas", "Do convés do Barco todos os barcos..."[62]).

Com o propósito de examinar um pouco mais detidamente esse tipo de aceno metafísico, que aproxima Álvaro de Campos e Fernando Pessoa ortônimo, transcrevo abaixo algumas passagens de "Ode Marítima":

\section{(...)}

Ah, todo o cais é uma saudade de pedra!

E quando o navio larga do cais

E se repara de repente que se abriu um espaço

Entre o cais e o navio,

Vem-me, não sei por quê, uma angústia recente,

Uma névoa de sentimentos de tristeza

Que brilha ao sol das minhas angústias relvadas

Como a primeira janela onde a madrugada bate,

E me envolve como uma recordação duma outra pessoa

Que fosse misteriosamente minha.

Ah, quem sabe, quem sabe,

Se não parti outrora, antes de mim,

Dum cais; se não deixei navio ao sol 
Oblíquo da madrugada,

Uma outra espécie de porto?

Quem sabe se não deixei, antes de a hora

Do mundo exterior como eu o vejo

Raiar-se para mim,

Um grande cais cheio de pouca gente,

Duma grande cidade meio-desperta,

Duma enorme cidade comercial, crescida, apoplética,

Tanto quanto isso pode ser fora do Espaço e do Tempo?

Sim, dum cais, dum cais dalgum modo material,

Real, visível como cais, cais realmente,

O Cais Absoluto por cujo modelo inconscientemente imitado

Insensivelmente evocado,

Nós os homens construímos

Os nossos cais de pedra atual sobre água verdadeira,

Que depois de construídos se anunciam de repente

Coisas-Reais, Espíritos-Coisas, Entidades em Pedra-Almas,

A certos momentos nossos de sentimento-raiz

Quando no mundo-exterior como que se abre uma porta

$\mathrm{E}$, sem que nada se altere,

Tudo se revela diverso.

Ah o Grande Cais donde partimos em Navios-Nações!

O Grande Cais Anterior, eterno e divino!

De que porto? Em que águas? E por que penso eu isto?

Grande Cais como os outros cais, mas o Único.

(...)

Repare-se que Álvaro de Campos não apenas fala de um "Cais Absoluto", de um "Grande Cais Anterior", mas consigna-lhe, platonicamente, uma função de arquétipo, de "modelo inconscientemente imitado", pelo qual "Nós os homens construímos / Os nossos cais de pedra ...”. Dizendo de outro modo, os cais construídos no plano sensível são mimesis, inspiradas em "reminiscências" do Cais arquétipo contemplado pela alma humana numa outra existência, numa outra hora ("outrora"). Daí, as evocações, as exclamações nostálgicas: “Ah, todo o cais é uma saudade de pedra!”; “Ah, quem sabe, quem sabe, / Se não parti outrora, antes de mim, / Dum cais; se não deixei navio ao sol / Oblíquo da madrugada, / Uma outra espécie de porto?”; “Ah o Grande Cais donde partimos em Navios-Nações!". 
Sobre o paralelo com a doutrina platônica das "Idéias", penso que a analogia não é abusiva. É certo que o "Grande Cais Anterior" é, a certa altura da Ode, qualificado como "eterno e divino", e isto pode ser visto como indicativo de uma maior afinidade com doutrinas religiosas, ou mesmo com algum dos neoplatonismos diversos, que mesclam filosofia e religião. Mas a hipótese de uma direta inspiração na "doutrina das idéias" não fica descartada, pois, além do expressivo conhecimento de Fernando Pessoa sobre as teses do filósofo ateniense, há que se pesar o fato de que também este, referindo-se aos seus arquétipos, dizia que, por serem eternos, perfeitos e incorruptíveis, mereciam o qualificativo de "divinos".

"Sentir tudo de todas as maneiras", eis um verso bem conhecido, que soa como uma espécie de refrão do sensorialismo exacerbado de Álvaro de Campos. Podemos encontrá-lo, literalmente repetido, em diferentes poemas. Primeiramente, em trechos de "Passagem das Horas" [445] $\left.{ }^{69}: 1\right)$ "Sentir tudo de todas as maneiras, / Viver tudo de todos os lados, / Ser a mesma coisa de todos os modos possíveis ao mesmo tempo, / ..."; 2) "Sentir tudo de todas as maneiras, / Ter todas as opiniões, / ...".

O escopo dessa pluralização sensorialista é, aqui, bem patente: transcender os limites da consciência subjetiva, multiplicar indefinidamente todos os pontos de vista ("Viver tudo de todos os lados"; "Ter todas as opiniões"), reunindo dentro de si e no

\footnotetext{
${ }^{69}$ Tal como se apresenta na edição em que me baseio, o texto deste poema apresenta-se como um corpo inteiro. Entretanto, resulta de uma montagem de fragmentos deixados por Fernando Pessoa. Maria Aliete Galhoz, organizadora da citada edição, tomou por base não os originais, mas a edição já publicada pela editora Ática, a qual, por sua vez, segundo Teresa Rita Lopes, “... cometeu o abuso de articular entre si, como se de um único texto se tratasse, nove folhas soltas (quinze páginas), dactilografadas que, de facto, constituem cinco diferentes momentos de escrita". (LOPES, 1997. p.26). Embora Fernando Pessoa tenha planejado esse texto como um corpo inteiro, prossegue Teresa Rita Lopes, assinalando que ele "... apenas compôs fragmentos, embora alguns deles sejam trechos com autonomia." Em suma, “... não há uma só Passagem, mas várias, mais ou menos estruturadas, cada uma com direito à sua autonomia." (LOPES, 1997. p.31).
} 
próprio tecido poético todas as espécies de contradições, para assim alcançar o absoluto. Observe-se a assimetria dos versos, o ritmo solto, exuberante e imprevisível, a ausência de rima e convenções preestabelecidas, assim como os verbos no modo infinitivo ("Sentir", "Viver", "Ser", "Realizar", “Ter”, Desagradar", "amar") e a abundância de pronomes indefinidos ("tudo", "toda", "todos", "todas"). São alguns dos recursos estilísticos que contribuem para reforçar esse anseio de impessoalidade e infinitude que atravessa não só esse poema, mas a maior parte da poesia de Álvaro de Campos.

Passando a um outro poema [518], datado de muitos anos mais tarde, precisamente de 1935, reencontramos, dentro da primeira estrofe, o mesmo verso refrão sensacionista, utilizado em "Passagem das Horas":

Afinal, a melhor maneira de viajar é sentir.

Sentir tudo de todas as maneiras.

Sentir tudo excessivamente,

Porque todas as coisas são, em verdade, excessivas

E toda a realidade é um excesso, uma violência,

Uma alucinação extraordinariamente nítida

Que vivemos todos em comum com a fúria das almas,

O centro para onde tendem as estranhas forças centrífugas

Que são as psiques humanas no seu acordo de sentidos.

$(\ldots)$

Note-se que os recursos estilísticos, que aqui reforçam esse "Sentir tudo de todas as maneiras", são praticamente os mesmos de "Passagem das Horas": a assimetria dos versos, a soltura rítmica, a ausência de rima, a abundância de pronomes indefinidos (“tudo", "toda", "todos", “todas"), o uso oportuno dos verbos "sentir" e "viajar" no modo infinitivo. A estes se acrescentam outros recursos não menos eficazes, por exemplo: a anáfora que realça o "Sentir tudo..." (segundo e terceiro versos da estrofe); o uso insistente do substantivo "excesso" (sexto verso) e seus derivados "excessivamente" (terceiro verso), "excessivas" (quarto verso); a extrema variação das pessoas verbais, 
que mudam de verso em verso, oscilando entre o infinitivo impessoal, a primeira pessoa do plural e a terceira do singular e do plural, numa rotatividade constante.

Na seqüência, uma estrofe se destaca pelo uso intensivo da anáfora. Transcrevo-a abaixo:

\section{$(\ldots)$}

Quanto mais eu sinta, quanto mais eu sinta como várias pessoas, Quanto mais personalidades eu tiver,

Quanto mais intensamente, estridentemente as tiver,

Quanto mais simultaneamente sentir com todas elas,

Quanto mais unificadamente diverso, dispersadamente atento,

Estiver, sentir, viver, for,

Mais possuirei a existência total do universo,

Mais completo serei pelo espaço inteiro fora.

Mais análogo serei a Deus, seja ele quem for,

Porque, seja ele quem for, com certeza que é Tudo,

E fora d'Ele há só Ele, e Tudo para Ele é pouco.

\section{$(\ldots)$}

As duas anáforas — "Quanto mais ..." (repetida no início de seis versos consecutivos) e "Mais ..." (três repetições, também no início de versos consecutivos) — dominam quase toda a estrofe, recriando a idéia central do poema, a saber: a meta, preconizada já no "Ultimatum" (1917), de se obter, pela via da multiplicação sensorialista, “... uma aproximação concretizada do Homem-Completo, Homem-Síntese da Humanidade”, “... para assim aproximar o mais possível d'aquela Verdade-Infinito, para a qual idealmente tende a série numérica das verdades parciais. ${ }^{70}$ Em outras palavras, "Como tudo é subjetivo, cada opinião é verdadeira para cada homem: a maior verdade será a Soma-síntese-interior do maior número d'estas opiniões verdadeiras que se contradizem umas às outras",71.

\footnotetext{
${ }^{70}$ PESSOA (CAMPOS), 1995. p.517-19.

${ }^{71}$ PESSOA, 1995. p.518.
} 
Todavia, em lugar de um direcionamento para a síntese, o que se delineia, de certo momento em diante, é a dispersão de todo o seu ser fragmentário, pela ação das tensões contrárias que o traspassam:

\section{(...)}

Sou um monte confuso de forças cheias de infinito Tendendo em todas as direções para todos os lados do espaço.

(...)

Sou uma chama ascendendo, mas ascendendo para baixo e para cima. Ascendendo para todos os lados ao mesmo tempo, sou um globo De chamas explosivas buscando Deus e queimando A crosta dos meus sentido, o muro da minha lógica. A minha inteligência limitadora e gelada.

(...)

Sou um formidável dinamismo obrigado ao equilíbrio

De estar dentro do meu corpo, de não transbordar da minh'alma.

Ruge, estoira, vence, quebra, estrondeia, sacode.

Freme, treme, espuma, venta, viola, explode,

Perde-te, transcende-te, circunda-te, vive-te, rompe e foge.

Sê com todo o meu corpo todo o universo e a vida,

Arde com todo o meu ser todos os lume e luzes,

Risca com toda a minha alma todos os relâmpagos e fogos,

Sobrevive-me em minha vida em todas as direções!

Note-se que, malgrado os recursos estilísticos que fortalecem a idéia de movimento contínuo, em direção à infinitude visada - uso intensivo de pronomes indefinidos ("todos", "todas") e os verbos no gerúndio ("tendendo", "ascendendo", "buscando", "queimando") —, o que finalmente se evidencia é a total impossibilidade da conciliação das diferenças e contradições na suposta "Verdade-Infinito".

A impossibilidade dessa conciliação se agudiza na estrofe final, não apenas no nível explícito do discurso, mas também no estilístico, devido ao realce que lhe conferem certos recursos, por exemplo: a construção de três versos consecutivos, exclusivamente com verbos (dezoito ao todo, seis em cada verso), a variação das vozes, 
tempos e modos verbais ao longo do período (ora na primeira ou terceira pessoa do singular do presente do indicativo, ora na segunda do singular do imperativo, algumas vezes na forma pronominal), recursos que se conjugam para recriar poeticamente a dissociação incontornável desse eu hipertrofiado.

A enumeração caótica não é um recurso estilístico recorrente nos poemasCampos. Todavia, é utilizada em "Passagem das Horas", numa longa seqüência de versos, que merecem ser comentados:

(...)

Rumor tráfego carroça comboio carros eu sinto sol rua, Aros caixotes trolley loja rua vitrines saia olhos

Rapidamente calhas carroças caixotes rua atravessar rua

Passeio lojistas "perdão" rua

Rua a passear por mim a passear pela rua por mim

Tudo espelhos as lojas de cá dentro das lojas de lá

A velocidade dos carros ao contrário nos espelhos oblíquos das montras,

$\mathrm{O}$ chão no ar o sol por baixo dos pés rua regas flores no cesto rua

$\mathrm{O}$ meu passado rua estremece camion rua não me recordo rua ${ }^{72}$

Eu de cabeça pra baixo no centro da minha consciência de mim

Rua sem poder encontrar uma sensação só de cada vez rua

Rua pra trás e pra diante debaixo dos meus pés

Rua em X em Y em Z por dentro dos meus braços

Rua pelo meu monóculo em círculos de cinematógrafo pequeno,

Caleidoscópio em curvas iriadas nítidas rua. ${ }^{73}$

Bebedeira da rua e de sentir ver ouvir tudo ao mesmo tempo. ${ }^{74}$

Bater das fontes de estar vindo para cá ao mesmo tempo que vou para lá .

(...)

\footnotetext{
72 Segundo LOPES, 1997. p.176, a estrofe não termina aqui, prolongando-se até o verso "Kaleidoscopio em curvas iriadas nitidas rua."

${ }^{73}$ Segundo LOPES, 1997. p.176, este verso finaliza a estrofe.

${ }^{74}$ Segundo LOPES, 1997. p.176, este verso inicia uma outra estrofe, seguindo-se ao verso seguinte um espaço em branco, deixado por Fernando Pessoa.
} 
Recurso inspirado em postulados futuristas ${ }^{75}$, esta longa seqüência de versos registra imagens e ruídos do cotidiano citadino, mesclando-os, de modo desconexo, com fragmentos de pensamentos, lembranças e sensações diversas. A mistura de objetos animados e inanimados, a transitar por dentro do poeta e pela exterioridade que o circunda, promove associações inesperadas, mostrando-se um recurso extremamente eficaz no sentido de recriar o vertiginoso desse contexto. Quebrando as regras da pontuação, desagregando a sintaxe habitual, as repetidas irrupções do substantivo "rua" aceleram o fluxo verbal, recriando, no plano poético, a onipresença e a vertiginosidade desse espaço citadino. A menção ao "cinematógrafo" associa a vivência acelerada dos transeuntes numa rua de grande cidade com a rapidez que caracteriza o modo de percepção das imagens nessa forma de arte, como que antecipando as conhecidas observações de Walter Benjamin. Como observa Lind, através desse recurso “... o Sensacionismo é levado às últimas consequiências: o mundo e o Eu transformam-se num rodopiar vertiginoso e caleidoscópico." 76

Outras estratégias secundárias contribuem para recriar essa atmosfera desumanizante - por exemplo: o uso abundante de verbos no infinitivo (como preconizado por Marinetti); a imagem multiplicadora dos "espelhos" obliquamente colocados em meio ao caos das imagens em movimento (eles não refletem as coisas fielmente, objetivamente, como o espelho do poema [285], de Caeiro; pelo contrário, refletem tudo ao contrário ...").

\footnotetext{
75 A propósito, Lind registra um trecho de Marinetti, exortando o poeta a renunciar à coordenação das sensações desconexas: “... [il futurismo] vuole la libera esplosione delle parole, lanciate alla folla o butate sulla carta secondo che le sensazioni sconesse si presentano allo spirito, il quale ha rinunciato a coodinarle." (MARINETTI apud LIND, 1970. p. 180).

${ }^{76}$ LIND, 1970. p. 190.
} 
É bem vasto o repertório das estratégias retóricas e estilísticas, usadas por Pessoa-Campos para recriar o sentido de fragmentação, ruptura, dissolução do eu. Vai desde recursos, digamos mais simples, como no verso "Sou uma sensação sem pessoa correspondente" [468], onde a diluição do eu é realçada pela provocativa inversão dos termos que compõem o predicado, até estratégias mais complexas, que envolvem a construção de metáforas e supra-sentidos, com base num vocabulário surpreendentemente coloquial.

Veja-se, por exemplo, a seguinte passagem: "Eu? Mas sou eu o mesmo que aqui vivi, e aqui voltei, / E aqui tornei a voltar, e a voltar, / E aqui de novo tornei a voltar, e a voltar? / Ou somos, todos os Eu que estive aqui ou estiveram, / Uma série de contas-entes ligadas por um fio-memória, / Uma série de sonhos de mim de alguém de fora de mim?" [452].

As idas e vindas desse Eu, sempre para o mesmo lugar, recriam no plano poético o seu devir interno e a sua impossibilidade de coincidir consigo mesmo. Contribuem para esse efeito metafórico: o uso repetido do verbo "voltar" (verbo de ação), por contraste com o advérbio "aqui”" (neste mesmo lugar), igualmente repetido; a alternância de tempo passado e tempo presente, assim como de pessoas verbais ("sou" / “vivi” / "voltei” / "tornei a voltar" / "somos" / "estive" / "estivemos"), sugerem alternâncias relativas ao movimento de proximidade e afastamento e do plano de particularização e generalização.

No trecho que se segue — "Eu o foco inútil de todas as realidades,/ Eu o fantasma nascido de todas as sensações / $\mathrm{Eu}$ o abstrato, eu o projetado no écran, Eu a mulher legítima e triste do Conjunto, / Eu sofro ser eu através disto tudo como ter sede 
sem ser de água." [521] — a anáfora do pronome "Eu", repetido no início de todos os versos, chama a atenção para o sentido negativo dos epítetos que lhe são atribuídos ("foco inútil”, “fantasma”, "abstrato”, “ projetado no écran”, "mulher legítima e triste do Conjunto"), assim como as expressões com pronomes indefinidos ("todas as ...", "através disto tudo").

A metáfora da "máscara", consagrada por Nietzsche no sentido de denúncia dos disfarces usados pelo homem para encobrir seus sentimentos mais ocultos e profundos — "Toda filosofia também esconde uma filosofia, toda opinião é também um esconderijo, toda palavra também uma máscara" ${ }^{, 77}$ —, tem um lugar privilegiado em momentos diversos da poesia Campos, aparecendo tanto em rápidas e instigantes menções - "O horror súbito do enterro que passa / E tira a máscara a todas as esperanças" (522) —, quanto com foros de conceito-chave, como é o caso desse instigante poema, que abaixo transcrevo:

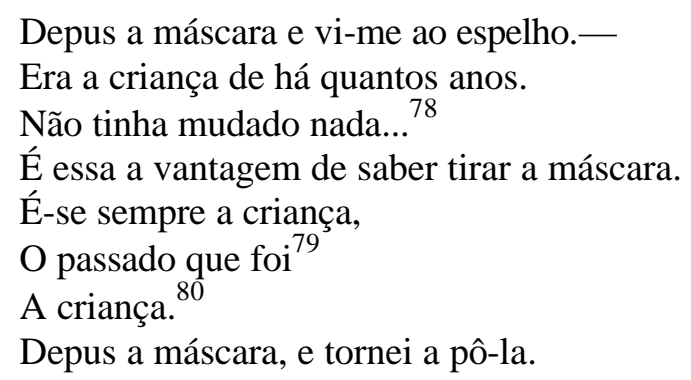

\footnotetext{
${ }^{77}$ NIETZSCHE, 1992. p.193. A propósito da sintonia com Nietzsche, Leyla Perrone-Moisés faz notar a proximidade de algumas perguntas pessoanas com “... 'perguntas capitais' do filósofo de "Além do bem e do mal": 'Somos autênticos ou nada mais do que atores, autênticos como atores ou apenas parodiamos o ator, somos o representante de algo ou aquilo que é representado? ... 'Ninguém' ou um encontro de ninguém?'. E a resposta, resguardadas as diferenças, é ainda a de Nietzsche: 'Sou apenas fragmento, enigma e pavoroso acaso'." (PERRONE-MOISÉS, 1990. p.29).

${ }^{78}$ Segundo LOPES, 1997. p.335, a primeira estrofe termina aqui.

${ }^{79}$ Segundo LOPES, 1997. p.335, o verso finaliza com o termo "fica".

${ }^{80}$ Segundo LOPES, 1997. p.335: esta estrofe termina aqui, iniciando-se uma outra com o verso seguinte.
} 
Assim é melhor,

Assim sem ${ }^{81}$ a máscara. ${ }^{82}$

E volto à personalidade ${ }^{83}$ como a um términus de linha.

O sentido de fragmentação e debilitação sucessiva da noção do eu como algo unitário e internamente coerente é estilisticamente realizado através de alguns procedimentos.

Primeiramente, note-se a variação dos tempos, pessoas, modos e vozes verbais. São recursos que contribuem para recriar, no plano da palavra poética, a distância temporal entre o surgimento dos vários "eus" / "máscaras" e enfatizam as mudanças de ponto de vista.

Note-se, também, que o "espelho" aqui referido, não apenas multiplica ou reflete ao inverso, mas vai mais fundo: reproduz a fragmentação interna do sujeito que nele se contempla, pondo a nu a sua não coincidência consigo mesmo.

A alusão metafórica à “criança de há quantos anos”, que, de início, parece trazer à tona uma suposta autenticidade anterior, uma face mais verdadeira, é debilitada pelo jogo de mascaramento / desmascaramento que a transforma numa outra máscara possível desse eu evanescente: a infância revela-se, afinal, como uma outra máscara, uma outra construção.

Atente-se ao fato de que não se trata de simplesmente "tirar", mas de "depor" a máscara. Embora os dois verbos tenham o mesmo número de sílabas e designem

\footnotetext{
${ }^{81}$ Segundo LOPES, 1997. p.335: "sou”.

${ }^{82}$ Segundo LOPES, 1997. p.335: esta estrofe termina aqui, seguindo a última estrofe, de um só verso.

${ }^{83}$ Segundo LOPES, 1997. p.335: "normalidade".
} 
a mesma ação, o segundo conota sentidos paralelos e bem sugestivos: pôr à parte, abandonar, destituir, privar do poder, enfim, libertar-se do jugo da máscara.

A figura do paradoxo, nos três últimos versos, recria essa indistinção entre as máscaras e a face verdadeira: "Assim é melhor, / Assim sem a máscara. / E volto à personalidade com a um términus de linha”. Note-se que também na versão apresentada pela Edição Crítica, de Teresa Rita Lopes, o jogo de paradoxos permanece — “Assim é melhor, / Assim sou a máscara. / E volto à normalidade ...". De um modo ou de outro, o eu verdadeiro se revela como mais uma ilusão: também ele é uma máscara, que só se descobre através de um artifício, ou seja, depois de depor e tornar a pôr a máscara.

Em muitos outros poemas, reaparece esse jogo paradoxal do mascaramento I desmascaramento, como metáfora da inautenticidade da existência humana. Citando mais um exemplo, veja-se o trecho abaixo, extraído de "Tabacaria":

$$
\text { (...) }
$$

Fiz de mim o que não soube,

E o que podia fazer de mim não o fiz.

$\mathrm{O}$ dominó que vesti era errado.

Conheceram-me logo por quem não era e não desmenti, e perdi-me.

Quando quis tirar a máscara,

Estava pegada à cara,

Quando a tirei e me vi no espelho,

Já tinha envelhecido.

Estava bêbado, já não sabia vestir o dominó que não tinha tirado.

Deitei fora a máscara e dormi no vestiário

Como um cão tolerado pela gerência

Por ser inofensivo

E vou escrever esta história para provar que sou sublime.

(...)

Nesta estrofe de treze versos livres, sem rima e de tamanho irregular, vários recursos recriam poeticamente a não coincidência do "eu" consigo mesmo e a idéia de que a existência é uma grande peça teatral, onde tudo tem alcance de representação, de 
construção ficcional. Repare-se, de modo geral, no uso intensivo de metáforas “máscara”, "espelho”, “dominó”, "vestiário” — esta última, sobremodo, reforçando a idéia de que também o ato de poetar se inclui nesse ciclo de construções ficcionais, colocando-se o poeta na posição paradoxal de ator e personagem de sua própria ficção. O paradoxo expresso no nono verso (“... já não sabia vestir o dominó que não tinha tirado") tem sua potência expressiva reforçada pela intensiva alternância dos tempos, pessoas, modos e vozes verbais ao longo de toda a estrofe.

As considerações acima nos remetem a uma temática de fundo, sobre a qual se constróem basicamente todos os poemas-Campos: a angústia existencial.

De certo, todo leitor que tenha alguma familiaridade com os poemasCampos concorda em que a angústia é aí um tema central. Não há como deixar de perceber as menções sempre enfáticas a esse sentimento obsidiante, cuja causa ele tenta em vão definir: "Sempre esta inquietação sem propósito, sem nexo, sem conseqüência,/ Sempre, sempre, sempre,/ Esta angústia excessiva do espírito por coisa nenhuma, / Na estrada de Sintra, ou na estrada do sonho, ou na estrada da vida ...” [463]. Essa angústia indefinível, que está em toda parte e não se localiza em alguma especialmente, é expressa não só pelo conteúdo explícito dos versos, mas também por diversas inflexões estilísticas, dentre as quais: a construção dos quatro versos sem verbo, sem ação, apenas com descrições circunstanciais; a anáfora, que dá relevo à idéia de plenitude e permanência temporal, através do advérbio "sempre" (por três vezes repetido no segundo verso), contrastando essa idéia com o sentido de privação, expresso pela preposição "sem" (igualmente repetida por três vezes); no mesmo sentido de 
contrastação, o uso do adjetivo "excessiva" para dar peso à angústia, e, logo em seguida, o complemento negativo “... por coisa nenhuma”.

Nesse outro trecho, note-se a incidência dos mesmos recursos estilísticos — anáforas, versos sem verbo ou com verbos substantivados - para recriar, no plano da poesia, o caráter indefinido e intempestivo da angústia relatada: "Súbita, uma angústia... / Ah, que angústia, que náusea do estômago à alma!”; "Uma angústia, / Uma desconsolação da epiderme da alma / Um deixar cair os braços ao sol-pôr do esforço" [475].

O eu poético é sempre o mesmo ser paradoxal, projetado sobre suas infinitas possibilidades e reduzido a um "intervalo", ou a menos que um "intervalo" entre o seu "desejo" (que, de per si, é paradoxal, é carência, falta de ser e, ao mesmo tempo, expectativa de plenitude), e a existência inautêntica, imposta de fora: "Começo a conhecer-me. Não existo. / Sou o intervalo entre o que desejo ser e os outros me fizeram, / Ou metade desse intervalo ...” [529].

Em outro poema: "Sou quem falhei ser./ Somos todos quem nos supusemos./ A nossa realidade é o que não conseguimos nunca" [487]. O sentido de negatividade, dúvida, contingência, é realçado pelos próprios verbos que definem o ser ("falhar", "supor", "não conseguir"), bem como pelas várias pessoas e tempos verbais (primeira do singular do presente do indicativo, primeira do plural do pretérito perfeito do indicativo; terceira do singular do presente do indicativo) em que esse ser se dispersa.

De fato a angústia, segundo reiteram os filósofos da corrente existencialista (na esteira de Kierkegaard, naturalmente), não tem causa específica, não se vincula a 
contingências, mas diz respeito à própria situação do homem no mundo, continuamente projetado para o futuro e às voltas com possibilidades, que tanto podem se concretizar quanto redundar em fracasso total. Não se confunde, portanto, com a inquietação e o temor de coisas determinadas. Estes são sentimentos substitutivos, pelos quais a angústia se extravasa, para tornar-se mais suportável (é mais fácil combater um inimigo visível, identificável, do que um invisível, escondido dentro de nossa própria alma).

É importante salientar que a angústia não se liga apenas à noção do futuro, enquanto horizonte de possibilidades indefinidas, mas também à consciência do passado, enquanto reservatório de possibilidades para sempre perdidas. É esse último tipo de sentimento que se expressa nos versos que se seguem: "O que só agora vejo que deveria ter feito, / O que só agora claramente vejo que deveria ter sido — / Isso é que é morto para além de todos os Deuses, / Isso — e foi afinal o melhor de mim — é que nem os Deuses fazem viver...// [...] // Pode ser que para outro mundo eu possa levar o que sonhei, / Mas poderei eu levar para outro mundo o que me esqueci de sonhar?" (462).

De um modo ou de outro, mesmo emergindo a propósito de situações triviais, corriqueiras, que mascaram a sua causa mais profunda, a angústia é sentida como onipresente. Não tem princípio nem causa definida. É antiga, originária mesmo, para além dos limites temporais da existência

Esta velha angústia,

Esta angústia que trago há séculos em mim,

Transbordou da vasilha,

Em lágrimas, em grandes imaginações,

Em sonhos em estilo de pesadelo sem terror,

Em grandes emoções súbitas sem sentido nenhum. 
Note-se o número significativo de anáforas e de versos sem verbo, apenas com função de complemento circunstancial, concretizando na palavra poética a impossibilidade de explicitação desse sentimento.

Em um ou outro poema, Campos fala de outros sentimentos análogos, como o tédio, a náusea, o cansaço, mas são, de fato, nomes diferentes para um mesmo sentimento, fundamental e onipresente. O poema seguinte é um bom exemplo:

Não, não é cansaço ...

É uma quantidade de desilusão

Que se me entranha na espécie de pensar,

É um domingo às avessas

Do sentimento,

Um feriado passado no abismo ...

Não, cansaço não é ...

É eu estar existindo

E também o mundo,

Com tudo aquilo que contém,

$\mathrm{Como}^{84}$ tudo aquilo que nele se desdobra

E afinal é a mesma coisa variada em cópias iguais.

Não. Cansaço por quê?

É uma sensação abstrata

Da vida concreta -

Qualquer coisa como um grito

Por dar,

Qualquer coisa como uma angústia

Por sofrer,

Ou por sofrer completamente,

Ou por sofrer como ...

Sim, ou por sofrer como ...

Isso mesmo, como ...

Como quê? ...

Se soubesse, não haveria em mim este falso cansaço.

${ }^{84}$ Segundo LOPES, 1997. p.305: "Com”. 


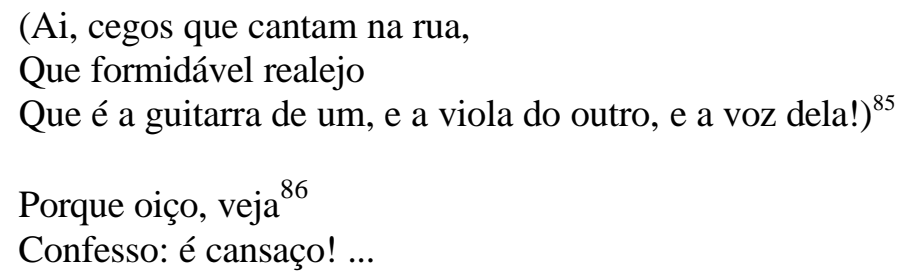

De modo geral, o uso intensivo das reticências no final dos versos (oito vezes ao longo do poema) já sugere a hesitação do eu poético em relação ao sentimento que o domina e que parece não ter causa nem configuração claramente identificável.

Além das anáforas ("Com tudo aquilo ..."; "Qualquer coisa como ...”; "Por”; “Ou por sofrer...”), vários termos e expressões reforçam a atmosfera de indefinição: “... uma quantidade de...”; “... na espécie de ...”; “... um domingo às avessas / Do sentimento"; "Um feriado passado no abismo ...”; “... a mesma coisa variada em cópias iguais"; “... um grito / Por dar”. É de se notar a incompletude semântica dos três últimos versos da terceira estrofe, todos terminados por reticências, assim com a contraposição: “sensação abstrata / "vida concreta". Na quinta estrofe, os três versos entre parênteses introduzem uma digressão que confere maior realce à confissão do cansaço, na última estrofe. As reticências no final do último verso, deixam em aberto o discurso, criando um efeito de perplexidade.

Como foi dito páginas atrás, nesse contexto de pensamento, o ideal de ataraxia mostra-se algo de todo impensável. A angústia é um tormento infindável, que não cessa nem mesmo com a morte: "Não durmo, nem espero dormir. / Nem na morte

\footnotetext{
${ }^{85}$ LOPES, 1997. p. 306nota: “ 'Voz dela' pode ser gralha: 'deles', os cegos, seria mais coerente. Não corrijo por admitir que entre 'os cegos' haja uma mulher."

${ }^{86}$ LOPES, 1997. p.306: "Vejo"
} 
espero dormir. / Espera-me uma insônia da largura dos astros, / E um bocejo inútil do comprimento do mundo." [468].

Ademais, o futuro, horizonte infinito dos possíveis, carrega em si desafios desconhecidos, dentre os quais a ocorrência da morte, que embora seja nossa única certeza, nunca sabemos como e quando vai acontecer, nem qual é a verdadeira face do "Mistério” que se situa “... do lado de lá das frontarias e dos movimentos”.

Atente-se ao poema abaixo, que, na edição que serve de base a esta consulta, recebe o número [459]:

\section{DEMOGORGON}

Na rua cheia de sol vago há casas paradas e gente que anda.

Uma tristeza cheia de pavor esfria-me.

Pressinto um acontecimento do lado de lá das frontarias e dos movimentos.

Não, não, isso não!

Tudo menos saber o que é o Mistério!

Superfície do Universo, ó Pálpebras Descidas,

Não vos ergais nunca!

O olhar da Verdade Final não deve poder suportar-se!

Deixai-me viver sem saber nada, e morrer sem ir saber nada! A razão de haver ser, a razão de haver seres, de haver tudo, Deve trazer uma loucura maior que os espaços

Entre as almas e entre as estrelas.

Não, não, a verdade não! Deixai-me estas casas e esta gente; Assim mesmo, sem mais nada, estas casas e esta gente... Que abafo ${ }^{87}$ horrível e frio me toca em olhos fechados? Não os quero abrir de viver! Ó Verdade, esquece-te de mim!

${ }^{87}$ Segundo LOPES, 1997. p.244: "bafo". 
Sobre o título "Demogorgon" (do gr. Daimõn, "demônio" + Gorgõ, "terrível”), é pertinente lembrar que “... a Górgona representa o irrepresentável: a morte, invisível e não-olhável...". ${ }^{88}$

Com a morte, presume o texto, dá-se a passagem para esse plano desconhecido, temível pelo "Mistério!" que envolve, pelo encontro com a "Verdade Final", cujo olhar "... não deve poder suportar-se". O uso das maiúsculas, nestes e noutros termos análogos ("Superfície do Universo"; "Pálpebras Descidas", "Verdade”) sinaliza o plano transcendente em que o poeta coloca essas entidades, que ele teme e trata por "vós", respeitosamente.

A noção de um "eu” unitário e condutor do seu discurso é debilitada através de estratégias retóricas e estilísticas como: a construção de apenas um verso com o verbo na primeira pessoa do singular, e assim mesmo com sujeito oculto; o numero expressivo de verbos no modo impessoal; a variação de tempos, pessoas e modos verbais, operando o deslocando contínuo do foco "narrativo".

Na primeira estrofe, a anáfora "cheia de" seguida de um complemento negativo — "sol vago"; "pavor" — dá relevo ao movimento oximoresco que aí se delineia.

No primeiro e segundo versos da segunda estrofe, a tensão interpretativa corre por conta: primeiro, da repetição intensiva do advérbio "não" referido ao pronome indefinido "isso"; segundo, do pronome indefinido "Tudo", cujo sentido é restringido pela preposição “menos”, indicativa de exceção.

${ }^{88}$ BRUNEL (Org.), 1997. p.621. 
Isto posto, cumpre ressaltar um outro ponto decisivo da poética de Álvaro de Campos: o rigor construtivo que caracteriza a concreção poética de seu exacerbado sensacionismo.

De fato, por um lado, o seu poetar se mostra imprevisível, defensor de uma extrema liberdade expressiva, contestador de convenções e formas preestabelecidas; por outro, isto não exclui um planejamento bem perceptível, que, se não é tão ostensivo como o das odes de Ricardo Reis, nem por isso é menos rigoroso.

Para exemplificar, escolho o poema de número [463], que, por não ser tão longo, transcrevo na íntegra:

Ao volante do Chevrolet pela estrada de Sintra, Ao luar e ao sonho, na estrada deserta, Sozinho guio, guio quase devagar, e um pouco Me parece, ou me forço um pouco para que me pareça, Que sigo por outra estrada, por outro sonho, por outro mundo, Que sigo sem haver Lisboa deixada ou Sintra a que ir ter Que sigo, e que mais haverá em seguir senão não parar mas seguir?

Vou passar a noite a Sintra por não poder passá-la em Lisboa, Mas, quando chegar a Sintra, terei pena de não ter ficado em Lisboa. Sempre esta inquietação sem propósito, sem nexo, sem conseqüência, Sempre, sempre, sempre, Esta angústia excessiva do espírito por coisa nenhuma, Na estrada de Sintra, ou na estrada do sonho, ou na estrada da vida...

Maleável aos meus movimentos subconscientes do ${ }^{89}$ volante, Galga sob mim comigo o automóvel que me emprestaram Sorrio do símbolo, ao pensar nele, e ao virar à direita. Em quantas coisas que me emprestaram eu sigo no mundo! Quantas coisas que me emprestaram guio como minhas! Quanto me emprestaram, ai de mim!, eu próprio sou!

À esquerda o casebre - sim, o casebre — à beira da estrada.

À direita o campo aberto, com a lua ao longe.

O automóvel, que parecia há pouco dar-me liberdade, É agora uma coisa onde estou fechado, Que só posso conduzir se nele estiver fechado, Que só domino se me incluir nele, se ele me incluir a mim.

${ }^{89}$ Segundo LOPES, 1997. p.252: "no". 
À esquerda lá para trás o casebre modesto, mais que modesto.

A vida ali deve ser feliz, só porque não é a minha.

Se alguém me viu da janela do casebre, sonhará: Aquele é que é feliz.

Talvez à criança espreitando pelos vidros da janela do andar que está em cima.

Fiquei (com o automóvel emprestado) como um sonho, uma fada real.

Talvez à rapariga que olhou, ouvindo o motor, pela janela da cozinha

No pavimento térreo,

Sou qualquer coisa do príncipe de todo o coração de rapariga,

E ela me olhará de esguelha, pelos vidros, até à curva em que me perdi.

Deixarei sonhos atrás de mim, ou é o automóvel que os deixa?

Eu, guiador do automóvel emprestado, ou o automóvel emprestado que eu guio?

Na estrada de Sintra ao luar, na tristeza, ante os campos e a noite,

Guiando o Chevrolet emprestado desconsoladamente,

Perco-me na estrada futura, sumo-me na distância que alcanço,

E, num desejo terrível, súbito, violento, inconcebível,

Acelero...

Mas o meu coração ficou no monte de pedras, de que me desviei ao vê-lo sem vê-lo,

À porta do casebre,

O meu coração vazio,

O meu coração insatisfeito,

O meu coração mais humano do que eu, mais exato que a vida.

Na estrada de Sintra, perto da meia-noite, ao luar, ao volante,

Na estrada de Sintra, que cansaço da própria imaginação,

$\mathrm{Na}$ estrada de Sintra, cada vez mais perto de Sintra,

Na estrada de Sintra, cada vez menos perto de mim...

Considerando-se o poema quanto à sua forma geral de apresentação, confirma-se a assimetria costumeira dos versos e estrofes de Campos, a soltura e imprevisibilidade do ritmo, a ausência de rimas e demais convenções poéticas. A impressão de espontaneidade é ainda mais realçada pela estrutura digressiva do discurso, que interrompe a toda hora a exposição central para trazer à tona lembranças, associações, pensamentos soltos e intempestivos. Um leitor menos avisado pode mesmo duvidar de que haja aqui um acentuado rigor construtivo.

Contudo, a bem se ver, a aparência de espontaneidade, de imprevisibilidade e liberdade estrutural, faz parte de um elaborado planejamento e de um sofisticado jogo de correlações. 
Note-se, em primeiro plano, o fluxo incessante de sensações, percepções, lembranças, associações de idéias, que se "interseccionam" dentro da mente desse motorista solitário, a guiar o seu automóvel emprestado pela estrada deserta. Passo a passo, o poema vai construindo um elaborado paralelismo entre: de um lado, os movimentos espirituais desse motorista; do outro, os movimentos desse automóvel emprestado, que "galga" sob ele, supostamente obedecendo aos seus comandos.

Essa duplicidade temporal, cumpre assinalar, tem matizes bergsonianos e proustianos: de um lado, o tempo exterior, o "tempo do relógio", objetivo, mensurável, como a velocidade do automóvel correndo pela estrada; do outro, o tempo interior, o "tempo vivido", subjetivo, não mensurável porque transcorre dentro da mente do guiador desse automóvel.

Atente-se, todavia, para o fato de que as sensações, as lembranças, os diferentes estados de ânimo do guiador do automóvel são descritos através de analogias com os balanços do automóvel, sugerindo-se, em alguns momentos, que é a máquina que dita o ritmo do seu pensamento.

Vários recursos estilísticos contribuem para consubstanciar, na forma poemática, a idéia da concomitância e permutabilidade desses ritmos e a instigante correlação entre o volante do automóvel e o volante interno (o "coração") do poeta.

Na primeira estrofe, é bem sugestiva a construção dos dois primeiros versos, sem verbo e sem sujeito, apenas com advérbios ou adjuntos adverbiais, pondo em relevo os dados circunstanciais e adiando ao máximo a informação sobre o sujeito e sobre a ação propriamente dita. Essa informação só aparece a partir do terceiro verso e, mesmo 
assim, de modo subentendido: o sujeito é indicado pela pessoa verbal ("guio”) e pelo adjetivo ("Sozinho").

Há, também, as várias expressões que sugerem certa hesitação do ritmo e do percurso (“... guio quase devagar .. “, "um pouco”, "Me parece”, “... ou me forço um pouco para que me pareça / Que sigo por outra estrada, por outro sonho, por outro mundo"). No quinto, sexto e sétimo versos, a anáfora ("Que sigo...) enfatiza a ação de "seguir", cujo sentido dúbio (ir atrás de, acompanhar, ir ao longo de) é realçado pela pergunta que finaliza a estrofe: “... e que mais haverá em seguir senão não parar mas seguir?".

Pouco a pouco, a aproximação analógica do motorista com a máquina emprestada vai se desenhando como uma expressiva metáfora da sua própria inautenticidade, ou seja, do seu constituir-se como um aglomerado de coisas emprestadas. $\mathrm{Na}$ terceira estrofe, de modo especial, os verbos "seguir", "guiar" e "ser" ganham sentido dúbio, através da anáfora com os pronomes indefinidos (“quantas", “quanto”): "Em quantas coisas que me emprestaram eu sigo no mundo! / Quantas coisas que me emprestaram guio como minhas! / Quanto me emprestaram, ai de mim!, eu próprio sou!".

Mundo exterior e mundo interior, real e imaginário, se interpenetram de modo imprevisível e indissolúvel, estabelecendo um vínculo tão estreito entre o guiador e o automóvel, que, de um lado, o automóvel parece humanizado, submisso aos seus comandos ("Maleável aos meus movimentos subconscientes do volante"), obedecendolhe como se fosse um prolongamento direto do seu próprio corpo ("Galga sob mim comigo o automóvel que me emprestaram”); do outro, é o próprio homem que se 
“maquiniza", submetendo o seu corpo à máquina e nela se incluindo como dentro de uma prisão: “O automóvel, que parecia há pouco dar-me liberdade, / É agora uma coisa onde estou fechado,/ Que só posso conduzir se nele estiver fechado,/ Que só domino se me incluir nele, se ele me incluir a mim."

Quanto mais acelerada a velocidade do automóvel maior o "descompasso" entre o eu do poeta e o mundo exterior, entre o "tempo vivido" e o "tempo do relógio". Quanto mais próximo do seu destino, mais distante de si mesmo, retido por lembranças passadas que de algum modo se imbricam no seu presente e com ele se integram (“Acelero... / Mas o meu coração ficou no monte de pedras, de que me desviei ao vê-lo sem vê-lo..."). Através das anáforas, esse hiato entre os dois tempos, o "vivido" e o "do relógio", é recriado nas duas últimas estrofes: "O meu coração..." (iniciando os três últimos versos da penúltima estrofe) e "Na estrada de Sintra ..." (iniciando os quatro versos da estrofe final).

São modos diversos e bem planejados, pelos quais o poema vai dizendo o seu sentido eminentemente contestador das formas prontas, dos conceitos clássicos, e, de passagem, deixando implícita uma crítica contundente à apologia futurista do maquinismo. A bem se ver, o poema denuncia, nas entrelinhas de um discurso aparentemente subjetivista, voltado apenas para o mundo interior do poeta, o limite interno da ideologia futurista. Não é apenas a duplicidade temporal, o traspassamento dos pensamentos e sensações dentro da mente, o tema do seu discurso, mas a outra face da mecanização. O automóvel — símbolo preferido da modernidade, associado ao poder, à velocidade, à liberdade, à emancipação — é, ao mesmo tempo, um instrumento de alienação e "maquinização" do homem. 
A circularidade, semântica e formal, é um outro modo de organização poemática recorrente nos poemas-Campos:

[505]

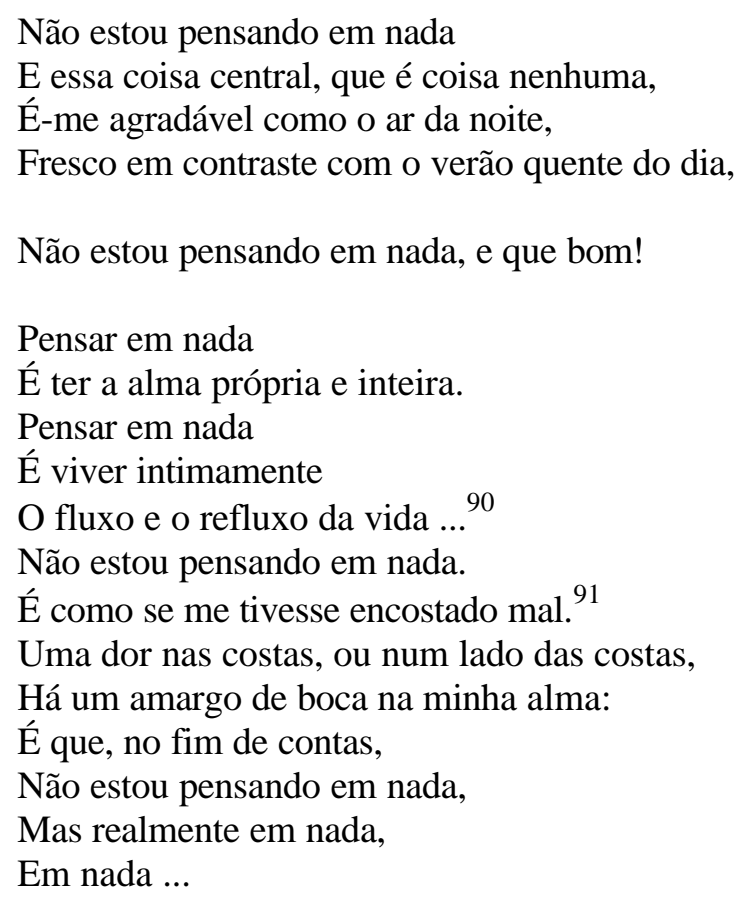

A composição gira em torno de uma idéia central, exposta no verso "Não estou pensando em nada", que se repete ao longo do poema, recriando uma circularidade formal e semântica. No plano da estrutura geral, essa exclusão do pensamento é recriada pela flagrante assimetria dos versos, todos de tamanhos extremamente variáveis, e das três estrofes, a primeira com quatro versos, a segunda com apenas um e a terceira com treze.

Na primeira estrofe, o segundo verso reforça o sentido negativo do verso inicial pelo uso da expressão "coisa central” (em lugar de "idéia central”), assim como

\footnotetext{
${ }^{90}$ LOPES, 1997. p.353: a estrofe termina neste verso, iniciando-se, com o verso seguinte, a última estrofe do poema.

${ }^{91}$ LOPES, 1997. p.353: o verso é: "Só, como se me tivesse encostado mal".
} 
pelo predicado “... coisa nenhuma”; o adjetivo "agradável”, no terceiro verso, instaura uma ambigüidade de sentido. A segunda estrofe, de um só verso — "Não estou pensando em nada, e que bom!" - aumenta esse contraste, gerando uma ambigüidade que se mantém até o quarto verso da terceira estrofe. Daí em diante, confirmando a estrutura cíclica dominante, retorna o sentido negativo dos dois primeiros versos. Essa circularidade formal, sem dúvida, tem uma correspondência semântica. Ademais, é relevante a repetição, por duas vezes, de um outro verso igualmente negativo: "Pensar em nada", assim como a repetição da palavra "nada" (por oito vezes, sempre relacionada ao verbo "pensar", ora no gerúndio, ora no infinitivo e, nos dois últimos versos, apenas subentendido. Mais que expressar o aprisionamento do poeta num círculo sem centro ou cujo centro "é coisa nenhuma", essa estrutura poemática é esse aprisionamento.

Ao longo de todo esse exame, há um ponto fundamental, que ainda não foi suficientemente discutido. Já foi ressaltada a diversificação extrema que preside à visão de mundo de Álvaro de Campos, a sua obsessão da multiplicação sensorial, e já se falou, também, da sua explícita intenção programática de alcançar, pela soma das verdades parciais, uma aproximação da verdade total, ou seja, “... d'aquela VerdadeInfinito", propugnada desde a fase do "Ultimatum". 92 Todavia, analisando-se atentamente os movimento intensivo desses "múltiplos" presentes em sua poesia, podese perceber que eles são mantidos como alteridades, sem qualquer aceno a encaminhamentos totalizantes e unificadores. Dito de outro modo, a diversidade é mantida como tal, sem tentativa de inserção num ritmo dialético conciliador, do tipo hegeliano. Daí,

92 PESSOA (CAMPOS), 1995. p.517-19. 
justamente, o seu fascínio, o seu poder de nos manter prisioneiros do seu dialogismo essencial.

Veja-se, no poema seguinte, o modo como os pólos opostos vão se justapondo e se alternando, promovendo uma permuta relativizante que impede qualquer tentativa de definição de um sentido unívoco:

[507]

Estou tonto,

Tonto de tanto dormir ou de tanto pensar,

Ou de ambas as coisas.

O que sei é que estou tonto

E não sei bem se me devo levantar da cadeira

Ou como me levantar dela.

Fiquemos nisto: estou tonto.

Afinal

Que vida fiz eu da vida?

Nada.

Tudo interstícios,

Tudo aproximações,

Tudo função do irregular e do absurdo,

Tudo nada.

É por isso que estou tonto...

\section{Agora}

Todas as manhãs me levanto

Tonto... ${ }^{93}$

Sim, verdadeiramente tonto ..

Sem saber em mim e meu nome,

Sem saber onde estou,

Sem saber o que fui,

Sem saber nada.

Mas se isto é assim, é assim.

Deixo-me estar na cadeira,

Estou tonto.

Bem, estou tonto.

Fico sentado

E tonto,

Sim, tonto,

Tonto...

Tonto.

93 Conforme LOPES, 1997. p.354, a estrofe não finaliza neste verso, unindo-se à seguinte. 
A sensação de vertigem é recriada, antes de mais nada, pelo ritmo irregular, marcado pelo contraste de versos extremamente curtos com versos longos, sem padrão fixo e previsível.

Além disso, o termo chave, "tonto", é não apenas repetido, mas inserido, nos dois primeiros versos, como peça de um jogo de palavras, "tonto / tanto", sugerindo ambigüidade, duplicidade de sentido.

Como se pode ver, cria-se um jogo insistente de contraposições sucessivas, que vão minando a coerência do discurso, debilitando e relativizando o sentido dos pólos positivo e negativo.

Observe-se, na segunda estrofe, a contraposição "Nada" / "Tudo". O termo negativo ganha preeminência especial, na medida em que constitui, sozinho, o terceiro verso da estrofe, isolando-se dos demais por um ponto final. Pelo contrário, o termo positivo é esvaziado, primeiramente, pela anáfora que o repete no início de quatro versos consecutivos, sempre seguido de complementos que lhe impõem uma flagrante redução de sentido; e além disso, pelos quatro últimos versos — "Tudo interstícios, / Tudo aproximações, / Tudo função do irregular e do absurdo / Tudo nada" — que exibem um desenho métrico de crescendo e brusco decrescendo (quatro, seis, onze e, subitamente, três sílabas), culminando no oxímoro do último verso.

$\mathrm{Na}$ quarta estrofe, o sentido negativo é sucessivamente recriado, tanto pelo jogo sonoro entre o "Sim" e o "Sem", no início dos versos, quanto pela anáfora e pelo desenho métrico decrescente (oito, seis, seis, quatro sílabas poéticas) dos quatro versos subsequentes: "Sem saber em mim e meu nome, / Sem saber onde estou,/ Sem saber o que fui, / Sem saber nada”. 
O "Mas", que inicia o primeiro verso da última estrofe, sugere que algo vai se opor a essa negatividade dominante. Porém, trata-se de mais um recurso para aumentar a tensão e realçar a tautologia frustrante que vem logo a seguir: “... se isto é assim, é assim". A retomada do verso inicial do poema — "Estou tonto" — é seguida de um novo decrescendo rítmico, efeito este que é realçado pela repetição intensiva do termo-chave "Tonto".

Para finalizar, transcrevo o poema [488], onde igualmente se recria o sentido de alternância e permutabilidade dos planos. Repare-se que os planos temporais diversos ora se contrapõem, ora se fundem, esvaziando-se reciprocamente através de uma dialética sem síntese, que envolve todo o discurso num halo de expectativa e indefinição:

\section{DATILOGRAFIA}

Traço sozinho, no meu cubículo de engenheiro, o plano, Firmo ${ }^{94}$ o projeto, aqui isolado,

Remoto até de quem eu sou.

Ao lado, acompanhamento banalmente sinistro,

O tique-taque estalado das máquinas de escrever. ${ }^{95}$

Que náusea da vida!

Que abjeção esta regularidade!

Que sono este ser assim!

Outrora, quando fui outro, eram castelos e cavaleiros ${ }^{96}$ (Ilustrações, talvez, de qualquer livro de infância), Outrora, quando fui verdadeiro ao meu sonho, Eram grandes paisagens do Norte, explícitas de neve, Eram grandes palmares do Sul, opulentos de verdes.

\footnotetext{
${ }^{94}$ Segundo LOPES, 1997. p.322, o verso se inicia com o termo "Fórmo".

${ }^{95}$ Segundo LOPES, 1997. p.322, a estrofe termina aqui, iniciando outra estrofe com o verso seguinte.

${ }^{96}$ Segundo LOPES, 1997. p.322, o verso finaliza com o termo "cavalerias".
} 
Outrora.

Ao lado, acompanhamento banalmente sinistro,

O tique-taque estalado das máquinas de escrever.

Temos todos duas vidas:

A verdadeira, que é a que sonhamos na infância,

E que continuamos sonhando, adultos num substrato de névoa;

A falsa, que é a que vivemos em convivência com outros,

Que é a prática, a útil,

Aquela em que acabam por nos meter num caixão.

Na outra não há caixões, nem mortes,

Há só ilustrações de infância:

Grandes livros coloridos, para ver mas não ler;

Grandes páginas de cores para recordar mais tarde.

Na outra somos nós,

$\mathrm{Na}$ outra vivemos;

Nesta morremos, que é o que viver quer dizer;

Neste momento, pela náusea, vivo na outra ...

Mas, ao lado, acompanhamento banalmente sinistro, ${ }^{97}$

Ergue a voz o tique-taque estalado das máquinas de escrever.

${ }^{97}$ Segundo LOPES, 1997. p.323, segue-se um verso, aqui omitido: "Se, desmeditando, escuto,", com uma variante a "escuto": "accordo". 


\section{FERNANDO PESSOA ORTÔNIMO}

Um aspecto que costuma intrigar os analistas de Fernando Pessoa ortônimo é a fisionomia vária e, sob certos aspectos, contraditória da sua poesia. Em boa parte, isto se deve a um difundido pressuposto, segundo o qual, a obra ortônima constituiria um porto seguro, onde se expressariam os verdadeiros sentimentos, crenças e pensamentos do homem Fernando Pessoa, por oposição às dos heterônimos que, resultando de desdobramentos ficcionais, seriam destituídas de compromisso com o pensamento do seu criador humano. Ora, à luz de tal suposição, o multidirecionamento da poesia ortônima só pode provocar perplexidade, e gerar, por conseguinte, anseio de resolução das supostas "contradições".

Meus pressupostos estéticos e filosóficos são bem diversos e, ao contrário dos acima comentados, levam-me a privilegiar a interpretação do texto poético tal como este se apresenta, sem intentos conciliadores de suas supostas contradições e sem preocupação com sua possível correspondência com a verdade pessoal de seu criador, antes, avaliando a própria multiplicidade como um sentido possível. Note-se que essa coexistência de intenções programáticas diferenciadas, dentro da poesia assinada por Fernando Pessoa ortônimo, é perfeitamente compatível com o conceito de "poética" aqui adotado, segundo o qual, tanto se pode falar do programa geral de um autor (ou de vários autores), quanto do programa que rege uma obra individual. 
O "Cancioneiro", "Mensagem" e os "dramas estáticos" compõem três diretrizes poéticas principais de Fernando Pessoa ortônimo. São segmentos diversos, mas que se entrelaçam em vários momentos e concordam em vários pontos. "Mensagem" é aqui tomado como um poema paradigmático, representativo do misticismo pessoano, já referido no Capítulo 3, e que, como se sabe, está presente em vários outros textos do poeta.

\subsection{Cancioneiro}

De modo geral, os poemas do Cancioneiro obedecem a uma poética que mescla raízes simbolistas com aquisições "interseccionistas", buscando realizar aquela já citada "ideação complexa”, pela qual é superada a unilateralidade do subjetivismo e do objetivismo em prol de uma comunhão "superpanteísta", que concilia os dois pólos, promovendo “... a espiritualização da Natureza e, ao mesmo tempo, a materialização do Espírito, a sua comunhão humilde no Todo...".

Dentro dessa linha programática, inclui-se, por exemplo, o poema abaixo, no qual se faz notar a interseção constante dos planos que compõem a realidade interior e a exterior:

É brando o dia, brando o vento.

É brando o sol e brando o céu.

Assim fosse meu pensa mento!

Assim fosse eu, assim fosse eu!

Mas entre mim e as brandas glórias

Deste céu limpo e este ar sem mim

Intervêm sonhos e memórias...

Ser eu assim, ser eu assim!

\footnotetext{
${ }^{1}$ PESSOA, 1995. p. 386.
} 
Ah, o mundo é quanto nós trazemos.

Existe tudo porque existo.

Há porque vemos.

E tudo é isto, tudo é isto!

Nos dois versos iniciais, o adjetivo "brando" é insistentemente repetido, com referência a elementos diversos da paisagem contemplada pelo eu poético. Essa redundância sem dúvida gera ambigüidade e, consequentemente, tensão informativa. Pode-se perguntar: a cada vez que aparece, o adjetivo "brando" terá o mesmo significado? A brandura que ele designa é da paisagem ou nela se reflete pelo anseio de quem a contempla?

Contudo, há uma diferença importante entre os dois versos: no primeiro, a estrutura assindética justapõe os dois segmentos, sem conjunção aditiva, separando-os apenas por vírgulas e compondo, assim, a única redondilha maior do poema; no segundo, a conjunção "e" conecta os dois segmentos, acrescentando uma sílaba ao verso e compondo, assim, um octossílabo. Essa alteração métrica assinala a passagem da objetividade do primeiro verso a subjetividade do segundo, ou seja, a passagem da “... sensação do objeto exterior como objeto” para “... a sensação do objeto exterior como sensação", tal como é preconizado pelo "Interseccionismo". ${ }^{2}$ No terceiro e no quarto versos — “Assim fosse meu pensa mento! / Assim fosse eu, assim fosse eu! —, não se trata mais nem da objetividade nem da subjetividade das sensações, mas do “... 'estado da mente' por meio do qual o objeto é visto naquele momento; o temperamento e a atitude mental fundamentalmente individual do observador"3 (no caso, o seu desejo de assimilar-se à paisagem contemplada), o que nos remete à terceira etapa do método

\footnotetext{
${ }^{2}$ PESSOA, 1995. p.442.
} 
“interseccionista" de decomposição das sensações. Observe-se, a propósito, a construção desses dois versos como o verbo "ser" no pretérito perfeito do subjuntivo, modo verbal adequado para reforçar a expressão do desejo. Note-se, além disso, nos dois versos iniciais, a ausência de verbo designativo de ação, reforçando a impressão de calmaria, de inação. O único verbo ("ser"), além de ser meramente copulativo, é usado na terceira pessoa do singular do presente do indicativo, designando um sujeito impessoal e emprestando uma impressão de impessoalidade e objetividade do relato. Quanto às rimas, são todas cruzadas ou alternadas. A do primeiro com o terceiro verso (vento e pensamento) é pobre e consoante, adequada à aproximação de palavras que, além de serem da mesma categoria gramatical, designam coisas de natureza semelhante, ambas igualmente efêmeras, transitórias. Já céu / eu é uma rima rica quanto à categoria gramatical e pobre quanto ao aspecto fônico, adequada à designação de entidades de natureza diversa: o parentesco sonoro limitado alerta quanto à natureza distinta dos referentes.

Passando à segunda estrofe, o "Mas" que a inicia sinaliza o caráter adverso dos "sonhos e memórias" que o contemplante sabe intervenientes em sua percepção. O "enjambement", que liga os três primeiros versos, bem como o tamanho mais longo do segundo verso (um eneassílabo) e a rima interna entre o "mim" do primeiro verso e o "sem mim" do segundo, realçam a intersecção das duas paisagens, a interior e a exterior. O anseio do contemplante por assimilar-se inteiramente à brandura da paisagem é reiterado no último verso da estrofe, só que, desta vez, com o verbo no modo despersonalizante do infinitivo, sugerindo uma dessubjetivação do discurso.

\footnotetext{
${ }^{3}$ PESSOA, 1995. p.442.
} 
O verso interjectivo que inicia a terceira e última estrofe expressa o lamento do contemplante, diante da subjetivação que lhe parece incontornável. As pessoas verbais, variando de verso para verso, como que reproduzem o vaivém do raciocínio, em seu oscilar do plano subjetivo para o abstrato. Note-se, a propósito, que, no primeiro verso, o verbo aparece, pela primeira vez, na primeira pessoa do plural do presente do indicativo ("trazemos"), estendendo a subjetivação a todo o gênero humano. O verso seguinte volta à primeira pessoa do singular, como que para verificação e confirmação, no plano pessoal, da generalização feita no antecedente. Rompendo com a seqüência dos octossílabos que vinham se sucedendo, o terceiro verso, "Há porque vemos", reveste-se de uma preeminência especial. Trata-se do único tetrassílabo do poema, devendo-se observar que o seu caráter de novidade é acentuado pelo fato de que, conquanto o poeta pudesse ter subdividido outros versos, ritmicamente compostos de dois versos de quatro sílabas, não o fez. Só o verso citado tem esta característica singular, como que pretendendo fechar de modo taxativo a alternância das afirmações que o antecedem. No último verso, enuncia-se a conclusão desoladora: "E tudo é isto, tudo é isto!" Observe-se o tom genérico e impessoal e o sentido redutor que advém da identificação entre "tudo" e "isto", por duas vezes repetida.

Como se vê, o poema tem em conta algumas diretrizes básicas do Interseccionismo, em especial, as três que se seguem:

1) “... toda sensação é realmente várias sensações misturadas”";

2) “... ao mesmo tempo que temos consciência dum estado de alma, temos diante de nós, impressionando-nos os sentidos que estão virados para o exterior, uma

\footnotetext{
${ }^{4}$ PESSOA, 1995. p.442.
} 
paisagem qualquer..."5. Sendo o nosso espírito, ele próprio, uma paisagem, daí resulta que

\begin{abstract}
“... temos ao mesmo tempo consciência de duas paisagens. Ora, essas paisagens fundem-se, interpenetram-se, de modo que o nosso estado de alma, seja ele qual for, sofre um pouco da paisagem que estamos vendo [...] e, também, a paisagem exterior sofre do nosso estado de alma"
\end{abstract}

3) a captura do entrelaçamento das impressões sensíveis, lembranças, associações e disposições anímicas diversas requer uma verdadeira decomposição sensorial, no sentido de tentar colher, ao mesmo tempo,

“... a sensação do objeto exterior como objeto; a sensação do objeto exterior como sensação; as idéias objetivas associadas a esta sensação — isto é, o 'estado da mente' por meio do qual o objeto é visto naquele momento; o temperamento e a atitude mental fundamentalmente individual do observador; a consciência abstrata por trás desse temperamento individual."

"Chuva oblíqua" compõe-se, em sua totalidade, de seis partes, e, já pelo próprio título, antecipa a idéia do movimento inclinado, de través, pelo qual se dá a intersecção ou traspassamento das impressões sensíveis com os estados da mente. Comento rapidamente "Chuva oblíqua I", tido como poema paradigma da "corrente" interseccionista:

Atravessa esta paisagem o meu sonho dum porto infinito

E a cor das flores é transparente de as velas de grandes navios

Que largam do cais arrastando nas águas por sombra

Os vultos ao sol daquelas árvores antigas ...

O porto que sonho é sombrio e pálido

E esta paisagem é cheia de sol deste lado...

Mas no meu espírito o sol deste dia é porto sombrio

\footnotetext{
${ }^{5}$ PESSOA, 1977. p.101.

${ }^{6}$ PESSOA, 1977. p.101.

${ }^{7}$ PESSOA, 1995. p.442.
} 
E os navios que saem do porto são estas árvores ao sol ...

Liberto em duplo, abandonei-me da paisagem abaixo...

O vulto do cais é a estrada nítida e calma

Que se levanta e se ergue como um muro,

E os navios passam por dentro dos troncos das árvores

Com uma horizontalidade vertical,

E deixam cair amarras na água pelas folhas uma a uma dentro...

Não sei quem me sonho...

Súbito toda a água do mar do porto é transparente

E vejo no fundo, como uma estampa enorme que lá estivesse desdobrada,

Esta paisagem toda, renque de árvore, estrada a arder em aquele porto,

E a sombra duma nau mais antiga que o porto que passa

Entre o meu sonho do porto e o meu ver esta paisagem

E chega ao pé de mim, e entra por mim dentro,

E passa para o outro lado da minha alma ...

Desde a abertura do poema, inicia-se o movimento de intersecção das duas paisagens, a exterior e a interior, a vivida e a imaginada, mesclando-se as impressões visuais com os estados anímicos, lembranças, associações e memórias diversas. É justo pensar numa contribuição, para a concepção dessa mesclagem imagética, da noção baudelaireana de que as coisas físicas mantêm uma relação de correspondência perfeita com as espirituais, interligando-se ambas por vínculos simbólicos. Do mesmo modo, respeitadas as diferenças programáticas de ambos, é útil pesar a influência ou inspiração de Pessoa na decomposição preconizada pelo cubismo. Naturalmente, como já foi lembrado no Capítulo 4, o poeta intenta representar a simultaneidade das sensações e não as várias faces do objeto, como é o caso da citada corrente pictórica.

Deixando prevalecer o imaginativo, o poeta contemplante vai mesclando, através de sucessivas metáforas, a luminosidade, transparência e dinamismo do cenário que está diante dos seus olhos com a escuridão, a opacidade, a calmaria, que habitam a sua mente e os seus devaneios. Daí resulta uma sugestiva sequência imagética, marcada pela aberta permuta entre o real e o sonhado. Como observa Lind, pouco a pouco, 
“... o porto imaginário ganha a supremacia, usurpando o lugar à paisagem real que, por sua vez, assume a forma imaginária, emergindo diante dos nossos olhos como ficção, como 'estampa' no fundo das águas do porto imaginário. Desta dupla paisagem estática solta-se a imagem mítica da nau ou caravela que, apesar do seu carácter imaginário, adquire tais foros de realidade que o poeta a distingue ou percepciona em ambos os planos simultaneamente, e sente que entra por ele dentro. Este fenómeno - a entrada da caravela na alma do poeta — sublinha mais uma vez a duplicidade da vivência, duplicidade esta provocada pela intersecção do sonho com a realidade."

O resultado não poderia ser outro: a dilação dos respectivos âmbitos do subjetivo e do objetivo, do interior e do exterior, do consciente e do inconsciente, do vivido e do onírico, com o conseqüente esmaecimento das fronteiras que os separam.

Estilisticamente, o verso livre, as estrofes de tamanhos diversificados, o ritmo irregular, as palavras fora da ordem habitual, contribuem para reforçar a impressão de gratuidade do processo perceptivo e de ausência de controle racional por parte do sujeito, por conseguinte, a impossibilidade do conhecimento especular.

Não é apenas o movimento de subjetivação da realidade externa que transparece nos poemas do Cancioneiro, mas também ao movimento de fusão temporal, conjugando-se ambos no sentido de reforçar a já citada impossibilidade do saber objetivo, especular:

Pobre velha música!

Não sei por que agrado, Enche-se de lágrimas

Meu olhar parado.

Recordo outro ouvir-te.

Não sei se te ouvi

Nessa minha infância

Que me lembra em ti.

Com que ânsia tão raiva

Quero aquele outrora!

E eu era feliz? Não sei:

\footnotetext{
${ }^{8}$ LIND, 1970. p.60.
} 
Fui-o outrora agora.

Trata-se de um poema ternário, cujas estrofes se compõem de redondilhas menores, excetuando-se a última, cujo terceiro verso é uma redondilha maior.

De modo geral, as rimas seguem o esquema do cruzamento ou alternância (o primeiro e o terceiro versos não rimam, apenas o segundo e quarto), verificando-se, além disso, uma heterogeneidade das categorias gramaticais dos termos envolvidosagrado (substantivo) e parado (adjetivo); ouvi (verbo) e ti (pronome); outrora (substantivo) agora (advérbio) — o que reforça as idéias de heterogeneidade dos elementos que compõem o processo perceptivo e de contínua alternância dos movimentos espirituais.

Já no primeiro verso — "Pobre velha música" — o poema nos informa de que se trata de uma música ouvida no presente, mas há muito conhecida pelo ouvinte, mesclando-se as impressões sonoras com as lembranças por ela evocadas, como que prenunciando a subjetivação de todo o percebido. Observe-se, no quarto verso da primeira estrofe, a interrupção da sequência de pentassílabos, passando ao tetrassílabo; a ausência de verbo, a menção à estaticidade do "olhar parado", recursos que recriam a idéia de que o único tipo de movimento é o que ocorre no interior da mente, idéia esta que é reiterada na sequência do poema.

Na segunda estrofe, o ouvinte começa a dialogar com a música, personificando-a, tratando-a com intimidade, colocando-a não apenas como interlocutora, mas como o outro termo de um diálogo do eu poético com o seu próprio passado, trazido para o presente; bem mais do que uma melodia, essa música soa, para ele, como a escuta do seu próprio passado, da sua infância. Observe-se que a rima do segundo verso 
com o quarto — ouvi e ti — é aguda, oxítona, reiterando a agudez da sensação de perda desse "outro ouvir-te", perdido no passado. É uma rima toante, que assemelha os termos apenas pela vogal tônica, sem promover uma perfeita identidade fônica, recurso que contribui para reforçar a relevância do "ti", que conclui o quarto verso e que é ponto culminante.

A terceira estrofe interliga o segundo e o quarto versos, através de uma rima consoante, cuja identidade fônica chama a atenção para a barra de separação entre os dois tempos, expressos pelo advérbio substantivado outrora (contração de outra hora, antigamente) e pelo advérbio agora (do latim hac hora, nesta hora, neste momento). A identidade fônica da rima consoante contribui para a fusão interseccionista das duas horas diferentes numa só hora.

O terceiro verso — "E eu era feliz? Não sei:" — merece uma atenção especial. Do ponto de vista métrico, observe-se que se trata do único heptassílabo do poema, portanto, de um verso maior que os demais (todos pentassílabos), realçando a complexidade do sentido evocado pela pergunta crucial, que põe em jogo não apenas a vivência antiga que a música evoca, mas a sua avaliação presente. O verso seguinte — "Fui-o outrora agora." - confirma essa tensão, enunciando o verbo "ser" no passado perfeito (sentido de coisa irrevogável, definitiva) e justapondo, de modo paradoxal, a hora passada e a presente, numa trama indestrinçável de sensações vividas e recordadas. Lembrando o dito bergsoniano, "A consciência é memória - conservação e acumulação do passado no presente". 9

\footnotetext{
${ }^{9}$ BERGSON, 1979. p.71.
} 
Vejamos agora um outro poema, que tem o ceticismo como nota predominante, sem qualquer aceno a verdades transcendentes:

Dorme, que a vida é nada!

Dorme, que tudo é vão!

Se alguém achou a estrada, Achou-a em confusão,

Com a alma enganada.

Não há lugar nem dia

Para quem quer achar,

Nem paz nem alegria

Para quem, por amar,

Em quem ama confia.

Melhor entre onde os ramos

Tecem dosséis sem ser

Ficar como ficamos,

Sem pensar nem querer,

Dando o que nunca damos.

Desde a estrofe inicial, manifesta-se uma disposição cética que, entretanto, pouco tem em comum com a que caracteriza o ceticismo filosófico. Em lugar de uma atmosfera zetética, inquisitiva, tem-se uma atmosfera pessimista, negativa, de apatia e desalento. Para a criação dessa atmosfera, o poeta se vale de alguns recursos estilísticos, por exemplo: a regularidade da métrica (todos os versos são hexassílabos); o uso repetido do verbo "dormir" (duas vezes), no modo imperativo, nos dois primeiros versos; a justaposição paradoxal do ato de achar ("achou a estrada") com a idéia de confusão e engano (“Achou-a em confusão / Com a alma enganada"); a sequiência de rimas nada / estrada / enganada realça, pelo parentesco fônico, a negatividade do contexto: termo final do último verso engloba fonicamente o termo final do primeiro verso $($ enganada $=$ engano + nada $)$. Na terceira estrofe, observe-se que a ação de tecer é atribuída a coisas inanimadas (os ramos), enquanto os seres vivos (nós) devem 
permanecer em estado de inércia, "Sem pensar nem querer, / Dando o que nunca damos."

O mesmo tipo de ceticismo, imerso em apatia e desalento, domina esse outro poema, cuja tônica é o total esvaziamento da noção clássica de sujeito-agente:

[160]

Entre o sono e o sonho,

Entre mim e o que em mim

É o quem eu me suponho,

Corre um rio sem fim.

Passou por outras margens,

Diversas mais além,

Naquelas várias viagens

Que todo o rio tem.

Chegou onde hoje habito

A casa que hoje sou.

Passa, se eu me medito;

Se desperto, passou.

E quem me sinto e morre

No que me liga a mim

Dorme onde o rio corre -

Esse rio sem fim.

A não coincidência do eu consigo mesmo é recriada no plano poético por alguns recursos estilísticos, tais como: a construção dos dois primeiros versos sem verbo, iniciados pela anáfora "Entre" (que realça a idéia de "intervalo"), com apenas dois substantivos ("sono" e "sonho"), sugestivos de um estado de supressão da atividade motora e perceptiva; a construção do segundo e terceiro versos em "enjambement", com oito pronomes ao todo, sem nenhum substantivo, com apenas um verbo copulativo (“É") e um indicativo de conjectura (“suponho"); a presença de um único verbo indicativo de movimento - "Corre" (no quarto verso) - que, no entanto, tem como sujeito "um rio sem fim". 
Na segunda estrofe, um novo "enjambement" liga o terceiro ao quarto verso, como que recriando o devir sinuoso do "rio sem fim", metáfora do fluxo contínuo e transitório da existência e dos estados anímicos. No mesmo sentido, veja-se as rimas em movimento cruzado, sendo que a do primeiro com o terceiro verso (margens e viagens) é pobre, quanto à categoria gramatical e rica quanto ao critério fônico; a do segundo com o quarto verso (além e tem) é rica quanto à categoria gramatical e quanto ao critério fônico.

$\mathrm{Na}$ terceira e quarta estrofes, os dois "enjambements" (primeiro e segundo versos; primeiro, segundo e terceiro versos), assim como as rimas compostas por verbos (habito e medito; sou e passou) têm a mesma função: realizar poeticamente a fugacidade do movimento de identificação do eu consigo mesmo.

Ao fim e ao cabo, o eu poético mostra-se de todo incongruente com o modelo unitário e transparente do "sujeito pensante" cartesiano, capaz de um saber exaustivo da realidade externa e de si mesmo. Pelo contrário, a marca desse eu é a opacidade, a incapacidade de conhecer a si próprio e ao mundo à sua volta, de distinguir entre o sono e o sonho, entre o dormir e o despertar. É o que se pode notar também nesse outro poema:

Durmo. Se sonho, ao despertar não sei

Que coisas eu sonhei.

Durmo. Se durmo sem sonhar, desperto

Para um espaço aberto

Que não conheço, pois que despertei

Para o que inda não sei.

Melhor é nem sonhar nem não sonhar

E nunca despertar. 
A estrofe única do poema compõe-se de doze versos com ritmo misto, alternando decassílabos e hexassílabos de acentuação interna variada. A tensão comunicativa é produzida pelo uso de rimas emparelhadas e "enjambements" diversos (do primeiro verso com o segundo, do terceiro ao sexto, do sétimo com o oitavo), contrastando a irregularidade e heterogeneidade de um plano com a regularidade e homogeneidade do outro. Note-se que o "enjambement" é aqui um recurso fundamental. Segundo me parece, o sétimo verso permite dupla leitura, na medida em que o acento interno pode recair tanto na segunda, quarta e décima sílabas, quanto na terceira, sexta e décima, o que contribui para reforçar o sentido paradoxal que por ele se enuncia e que é trazido ao primeiro plano pelo verso subsequente, ao qual se liga pelo "enjambement". Note-se, além disso, que os verbos saber (duas vezes), conhecer (uma vez), despertar (quatro vezes) se repetem, sempre acompanhados de um advérbio negativo ou limitados através do "enjambement" com um verso de sentido redutor. A repetição alternada dos verbos dormir, sonhar, despertar, ao longo do poema, propicia uma confusão de sentido.

O poema seguinte, malgrado a métrica e rima regulares, faz pensar numa proximidade com os poemas Álvaro de Campos, pelo sentimento de falência existencial, de total desalento diante do sentido fugaz da existência e da inanidade da razão humana, ambos descritos como tarefas infinitas, que nunca se cumprem inteiramente:

Tudo que faço ou medito

Fica sempre na metade.

Querendo, quero o infinito.

Fazendo, nada é verdade.

Que nojo de mim me fica

Ao olhar para o que faço!

Minha alma é lúcida e rica,

E eu sou um mar de sargaço - 
Um mar onde bóiam lentos

Fragmentos de um mar de além ...

Vontades ou pensamentos?

Não sei e sei-o bem.

A um primeiro olhar, o poema comunica uma impressão de regularidade, de simetria: estruturação em três estrofes do mesmo tamanho (quatro versos em cada uma); disposição regular das rimas externas, todas cruzadas ou alternadas; pelo fato de serem todas consoantes, ricas (segundo o critério da categoria gramatical) e pobres (do ponto de vista fônico), paroxítonas em sua quase totalidade (excetua-se apenas, na última estrofe, a rima oxítona além com bem).

Contudo, a um olhar mais detido, revelam-se detalhes que debilitam essa harmonia: 1) as estrofes, embora predominantemente compostas de heptassílabos (excetuando-se apenas o último verso do poema, que é um hexassílabo), possuem acentos internos variados; 2) tanto na primeira, quanto na segunda e na terceira estrofes, ocorrem "enjambements" do primeiro com o segundo verso: na primeira, esse recurso reitera o contraste entre "Tudo" (início do primeiro verso) e "metade" (final do segundo verso), operando uma flagrante redução do sentido do primeiro termo, o mesmo acontecendo com a contraposição de um verbo indicativo de permanência, "ficar" (segundo verso), a um verbo de ação, "fazer" (primeiro verso); na segunda estrofe, os verbos "ficar" e "fazer" são novamente contrapostos, enfatizando o caráter permanente do sentimento de nojo, por oposição à fugacidade de cada ação do sujeito poético; na terceira estrofe, os dois versos em "enjambement" são, de fato, um aposto do último verso da estrofe anterior: a metáfora do "mar de sargaço", que o eu poético diz ser, é explicada com uma outra metáfora, a de "Um mar onde bóiam lentos / Fragmentos de 
um mar além ...”, produzindo indefinição de sentido. À pergunta formulada no penúltimo verso, "Vontades ou pensamentos?", é dada uma resposta concisa e ambígua, num verso mais curto que os demais, "Não sei e sei-o bem", um hexassílabo com dois tipos de acentuação possível, o que instaura uma nova tensão interpretativa.

Examinemos agora um poema que, tradicionalmente, é incluído entre os expressivos do misticismo ortônimo:

Não meu, não meu é quanto escrevo.

A quem o devo?

De quem sou o arauto nado?

Por que, enganado, Julguei ser meu o que era meu?

Que outro mo deu?

Mas, seja como for, se a sorte

For eu ser morte

De uma outra vida que em mim vive,

Eu, o que estive

Em ilusão toda esta vida

Aparecida,

Sou grato Ao que do pó que sou

Me levantou.

(E me fez nuvem um momento

De pensamento.)

(Ao de quem sou, erguido pó, Símbolo só.)

Composto de uma só estrofe de 18 versos, esse poema contrasta a variabilidade das métricas com a regularidade do esquema das rimas, sempre emparelhadas. $\mathrm{O}$ tema da deposição do sujeito em relação à autoria do seu discurso já está todo contido no primeiro verso, que se separa dos demais por um ponto final. Nos cinco versos subseqüentes, enunciam-se quatro perguntas sem resposta, todas elas referentes à autoria dos citados discursos; enquanto o sétimo verso introduz uma digressão que vai até o final do poema, sempre debilitando o eu poético e reforçando a idéia da inautenti- 
cidade da sua vida "Aparecida". O décimo terceiro verso apenas sugere, pela maiúscula do "Ao", a natureza transcendente do verdadeiro autor dos discursos.

A sinceridade / insinceridade poética é o tema de um outro poema, bastante conhecido, pelo qual Fernando Pessoa reflete sobre o sentido e o alcance veritativo da prática poética e questiona, ao mesmo tempo, a concepção romântica da poesia como "confissão":
AUTOPSICOGRAFIA
O poeta é um fingidor.
Finge tão completamente
Que chega a fingir que é dor
A dor que deveras sente.
E os que lêem o que escreve,
Na dor lida sentem bem,
Não as duas que ele teve,
Mas só a que eles não têm.
E assim nas calhas de roda
Gira, a entreter a razão,
Esse comboio de corda
Que se chama o coração.

Nesse poema ternário, a regularidade da estrutura métrica e sonora contribui para realçar a eficácia expressiva dos paradoxos, que aí se apresentam como figura estilística central. É óbvio, não se trata, aqui, de um jogo gratuito, mas de uma estratégia retórica, pela qual o poema explora sentidos inacessíveis à linguagem comum e que dizem respeito ao caráter paradoxal da própria realidade que quer compreender, a saber, o ato poético, em sua dimensão ao mesmo tempo ficcional e veritativa.

O primeiro verso se destaca, dentro da estrofe e do poema, tanto pelo sentido provocativo que enuncia, quanto por detalhes de sua estruturação: além da pontuação 
conclusiva e da terminação oxítona, que promovem uma parada estratégica no ritmo do discurso, seu termo final, "fingidor", engloba fonicamente o termo final do terceiro verso, "dor" (fingidor $=$ finge + dor $)$, produzindo assim uma imagem paronomástica de submissão do sentimento natural (precedente ao ato poético) ao sentimento fictício, construído, objetivado poeticamente. O "enjambement" dos três versos subseqüentes recria essa idéia axial. Observe-se os jogos sonoros instituídos pelas palavras — finge, dor e fingidor; finge, completamente, sente - culminando no quarto verso, com a aproximação paradoxal da dor sentida como a fingida poeticamente. A aproximação é paradoxal, mas correta, pois é na medida em que se afasta da experiência imediata que a linguagem poética pode dizer o seu sentido próprio e, por conseguinte, a sua verdade. Todos esses recursos recriam a natureza paradoxal do sentimento expresso poeticamente, que não é nem real, nem simplesmente simulado: o poeta constrói-se como um outro e esse seu jogo de simulações tem por fim alcançar, na obra, a verdade que nunca se esgota nem se revela inteiramente.

A segunda estrofe nos coloca frente à natureza dialógica da leitura e interpretação dos textos poéticos, chamando a atenção, por um lado, para o duplo distanciamento de quem lê em relação ao sentimento real de quem escreve; por outro, para a natureza peculiar do sentimento poético, que é sem equivalente: não eqüivale nem à dor vivenciada pelo poeta, nem à dor sentida por quem lê, pois é, antes, um terceiro sentimento, de natureza puramente estética, que não coincide com as sensações das quais se origina ou que possa vir a suscitar. Os verbos ler, escrever, sentir compõem um processo de superposição interpretativa e reconstrutiva do sentido. 
Na terceira estrofe, a atmosfera lúdica dos jogos de palavras, iniciados desde o primeiro verso da primeira estrofe, ganha contornos mais definidos com a metáfora do coração transformado em brinquedo, "comboio de corda", que "Gira, a entreter a razão". A metáfora evoca algo de lúdico e evocativo do livre jogo entre razão e sensibilidade, que Kant vira como característico da arte e indicativo de sua autonomia frente a qualquer compromisso com o real.

Sobre o significado desse poema, destaca G. R. Lind o seu caráter de “... recusa da concepção romântica do poeta inspirado ..."10, em prol da essencialidade da intelectualização dos sentimentos no ato poético. De fato, já insistiam os escritos teóricos sobre o Sensacionismo em que não é a emoção em estado natural (que não passa de mera "emoção sem sentido") a matéria da arte. Para aceder ao domínio da arte, o sentimento tem de ser trabalhado, idealizado. ${ }^{11}$

Esse tipo de consciência, recorda Lind, aparece bem cedo na poesia de Pessoa, justamente num poema da fase final do Paulismo, onde já aparece, em toda a sua pujança, a meditação do poeta sobre a impossibilidade de se passar para o domínio da arte a sensação em estado original:

Ela canta, pobre ceifeira,

Julgando-se feliz talvez;

Canta, e ceifa, e a sua voz, cheia

De alegre e anônima viuvez,

Ondula como um canto de ave

No ar limpo como um limiar,

E há curvas no enredo suave

Do som que ela tem a cantar.

\footnotetext{
${ }^{10}$ LIND, 1970. p.305.

${ }^{11}$ Cf. Capítulo 4.
} 
Ouvi-la alegra e entristece,

Na sua voz há o campo e a lida,

E canta como se tivesse

Mais razões p'ra cantar que a vida.

Ah, canta, canta sem razão!

O que em mim sente 'stá pensando.

Derrama no meu coração

A tua incerta voz ondeando!

Ah, poder ser tu, sendo eu!

Ter a tua alegre inconsciência,

E a consciência disso! Ó céu!

Ó campo! Ó canção! A ciência

Pesa tanto e a vida é tão breve!

Entrai por mim dentro! Tornai

Minha alma a vossa sombra leve!

Depois, levando-me, passai!

Contrastando com a complexidade da reflexão, destaca-se a simplicidade construtiva do poema, obediente à estruturação tradicional e marcado pela significativa regularidade de suas seis estrofes, todas de igual tamanho (quatro versos de oito sílabas métricas).

As duas primeiras estrofes descrevem o canto da "pobre ceifeira". O adjetivo "pobre" já antecipa que não se trata de uma descrição objetiva, mas, pelo contrário, carregada de sentido valorativo, como comprovam as sucessivas conjecturas sobre o sentido desse canto, e que só encontram um ponto final no último verso da segunda estrofe. À felicidade conjecturada, interpõe-se no segundo verso, um "talvez", cujo final oxítono estabelece um parentesco sonoro com o quarto verso, justamente aquele que atribui à voz da ceifeira uma “... alegre e anônima viuvez”. Esse verso, encadeado com o anterior, através do "enjambement", confere ao vocábulo final desse último (justamente o adjetivo "cheia") um sentido de privação. No que se refere às outras rimas, pode-se 
destacar, na segunda estrofe, a consonância sugestiva que assimila o substantivo "ave" (primeiro verso) no interior do adjetivo "suave" (terceiro verso), efeito que é reforçado pela metáfora que associa o canto da ceifeira a "um canto de ave" que recorta o "ar limpo" com o seu desenho sinuoso. Os "enjambements" constituem um modo de realizar essa sinuosidade.

As estrofes subsequentes ressaltam a ambigüidade desse canto, que alegra e entristece: a sua alegria nasce da inconsciência. $\mathrm{O}$ forte tom interjectivo da quarta e quinta estrofes expressam o desalento do poeta diante de seu desejo ambíguo e impossível: canto ondeante e "sem razão" encontra rima no seu "coração", mas não consegue impedir a interposição do verso racional — "O que em mim sente 'stá pensando". As apócopes, (p'ra e 'stá, na terceira e quarta estrofes) reforçam a sua racionalidade vigilante e incontornável. Na quinta estrofe, a rima foneticamente imperfeita de "eu" (primeiro verso) com “céu” (terceiro verso), bem como pela aproximação de "inconsciência" (segundo verso) com "ciência" (quarto verso). A fugacidade da existência e a inutilidade de todo esse anseio são enfatizadas na última estrofe, pelos verbos indicativos de transitoriedade (tornar, levar, passar). Sucumbindo ao peso da ciência e à brevidade da vida, o eu poético se deixa dominar pelo desejo de que a sua alma se deixe arrastar como uma "sombra leve" daquele canto ondulante. Tem razão G. R. Lind, quando observa que

“... a ceifeira não é um motivo bucólico ao serviço da glorificação da vida campestre, mas sim a imagem contraposta à pessoa do poeta, vítima da excessiva consciência de si mesmo - 'o que em mim sente está pensando' ansioso por um estado de inconsciência, sem contudo poder renunciar a ter consciência disso. [...] a ceifeira, o seu trabalho e o seu canto servem de antítese objectiva aos elementos subjectivos do poema, à ânsia do poeta duma forma de existência não sobrecarregada com a consciência de si mesma."12

${ }^{12}$ LIND. 1970. p.53-4. 
O tema da sinceridade/insinceridade poética é retomado no poema "Isto", mais uma vez em oposição à concepção romântica, que a equipara à sinceridade emocional:

ISTO

Dizem que finjo ou minto

Tudo que escrevo. Não.

Eu simplesmente sinto

Com a imaginação.

Não uso o coração.

Tudo o que sonho ou passo,

O que me falha ou finda,

É como que um terraço

Sobre outra coisa ainda.

Essa coisa é que é linda.

Por isso escrevo em meio

Do que não está ao pé,

Livre do meu enleio,

Sério do que não é.

Sentir? Sinta quem lê!

Todas as três estrofes (que se compõem de hexassílabos) obedecem ao esquema de rimas $\mathrm{ABABB}$, correspondendo esse esquema ao sentido do que é exposto em cada uma - quer dizer, é como se fosse uma estrofe de quatro versos, com sentido completo, à qual se acrescenta mais um verso, independente, mas que vem reforçar o sentido já afirmado.

O primeiro e o segundo versos da primeira estrofe são encadeados (no segundo, o "Não", que constitui a última sílaba poética é enfatizado pela pontuação: um ponto antes e um depois). O "enjambement" do terceiro verso com o quarto chama a atenção para o significado do verbo sentir, mostrando que se trata de sentir e pensar por 
imagens, ou, kantianamente falando, de conjugar as intuições da sensibilidade com as exigências racionais do entendimento. ${ }^{13}$ Nesse mesmo sentido, escreve em outro lugar: "O poeta superior diz o que efetivamente sente", mas sente com a inteligência, quer dizer, usa a imaginação e não o coração. "Nada disso tem que ver com a sinceridade", ou seja, não se trata de sinceridade emocional, mas de sinceridade intelectual, “... e essa é que importa no poeta". ${ }^{14} \mathrm{Na}$ segunda e terceira estrofes, o "enjambement" tem um papel fundamental, como elemento de produção do sentido, podendo-se dizer que, unindo o terceiro e o quarto versos, ele não apenas confere realce à existência de uma "outra coisa", mas a recria linguisticamente; do mesmo modo, interligando o primeiro verso e o segundo, o "enjambement" recria a temática do distanciamento poético do eu em relação às emoções imediatas que perturbam o seu íntimo.

\subsection{Mensagem}

Como foi dito no capítulo 3, embora o misticismo esteja bem presente em vários momentos da poesia de Fernando Pessoa e também em heterônimos como Ricardo Reis, é particularmente sobre o sentido do misticismo de "Mensagem" que se tem concentrado a atenção da crítica pessoana, de algumas décadas para cá. ${ }^{15}$

\footnotetext{
${ }^{13}$ Em um de seus escritos teóricos, escreve Fernando Pessoa, leitor de Kant: "A arte é a expressão de um equilíbrio entre a subjetividade da emoção e a objetividade do entendimento...”. (PESSOA, 1995. p.253). (Grifo do autor).

${ }^{14}$ PESSOA, 1995. p.269.

15 A partir da década de oitenta, foram se intensificando os estudos sobre esse poema, negligenciado durante o salazarismo, por ser visto como um poema fascista.
} 
"Mensagem" poetiza acontecimentos decisivos da ascensão, apogeu e declínio de Portugal, operando uma revisitação da história marítima portuguesa, sob o ponto de vista da intervenção divina no rumo dos acontecimentos terrenos.

O critério dessa revisitação poética, como assinala Maria Helena Nery Garcez, é bem peculiar: “... ziguezagueia pela História, escolhendo personagens que considera decisivas sob o prisma anagógico com que a lê, deixando outras de lado". ${ }^{16}$

Assim selecionados, os fatos e as personagens da História elevam-se da sua literalidade terrena a uma esfera espiritual e mística superior, revestindo-se de valor simbólico e profético: são, mais precisamente, o modo assumido pela divindade para falar indiretamente a quem sabe decodificar seus sinais.

Não me detenho sobre o sentido do rico simbolismo desse poema. Noto, apenas, que, à semelhança do simbolismo/alegorismo, desenvolvido pela cultura medieval, a exegese não é, aqui, uma decifração aleatória. Os significados são previstos e elaborados segundo uma enciclopédia prefixada de símbolos esotéricos e ocultistas, cujo entendimento, segundo o próprio Fernando Pessoa, requer algumas condições interligadas: a simpatia, que é como que uma congenialidade, uma sintonia, uma disponibilidade do intérprete para com o material a ser interpretado; a intuição, que é “... aquela espécie de entendimento com que se sente o que está além do símbolo, sem que se veja"; a inteligência, que, atuando em consonância com as outras duas, decompõe e reconstrói o símbolo em outro nível (ela passa do estado de inteligência discursiva ao de inteligência analógica); a compreensão, que atua relacionando o símbolo com

\footnotetext{
${ }^{16}$ GARCEZ, 1989. p.97.
} 
outros símbolos e assim iluminando a sua compreensão; finalmente, uma condição que ele considera de difícil definição e que designa como “... a graça [...] a mão do Superior Incógnito [...] o Conhecimento e Conversação do Santo Anjo da Guarda, entendendo cada uma destas coisas, que são a mesma da maneira como as entendem aqueles que delas usam, falando ou escrevendo.",17

Por um lado, é patente a exaltação de uma dimensão atemporal, mística, inacessível à razão e detentora do verdadeiro significado dos atos humanos. Por outro, é importante ressaltar que esse misticismo exacerbado supõe, como correlato incontornável, a impotência do homem frente ao mistério do universo e da sua própria existência.

De fato, os dois aspectos mantêm uma relação de correspondência, apresentando-se a descrença no poder cognoscitivo do homem, a consciência da sua limitação, como um correlato necessário da exaltação da vontade divina como ordem suprema e transcendente que rege o universo. E como é bem próprio do estilo pessoano, sabidamente afeito à construção de paradoxos, a preeminência conferida, nos títulos dos poemas, às figuras dos heróis e vultos marcantes da História portuguesa tem um sentido paralelo de desvelamento da sua submissão à ordem misteriosa e sobrenatural que preside o destino da humanidade.

No que se refere à estrutura poemática, é profícuo observar, beneficiandonos das análises feitas por Maria Helena Nery Garcez, que, à semelhança do discurso de “Os Lusíadas", onde os acontecimentos são relatados por Camões através de um "euépico", que cede, muitas vezes, a palavra a outras vozes, o discurso de "Mensagem" se caracteriza por uma polifonia contínua, promovendo “... contínuos deslocamentos do

${ }^{17}$ PESSOA, 1977. p.69. (Nota preliminar). 
ponto de vista do discurso poético, que ora se constrói na terceira pessoa, ora na segunda, ora na primeira do singular ou do plural, ora principia na terceira e passa para a segunda ou para a primeira." 18

Apenas para ilustrar esse enfoque polifônico de "Mensagem", seleciono um de seus poemas: $O$ conde D. Henrique, Terceiro da parte II, Os Castellos.

[5]

Todo começo é involuntario.

Deus é o agente.

O heroe a si assiste, vario

E inconsciente.

À espada em tuas mãos achada

Teu olhar desce.

"Que farei eu com esta espada?"

Ergueste-a, e fez-se.

Apesar do seu tamanho diminuto, este poema se apresenta como um expressivo exemplo de estruturação livre das estrofes e dos versos e, sobretudo, de bruscas mudanças de tempos e pessoas verbais.

Os quatro versos que constituem a estrofe inicial fazem ouvir uma voz impessoal e onisciente, que põe em contraste a onipotência de Deus, único centro ativo da história humana, e a inconsciência do herói (D. Henrique, no caso), que a tudo assiste, numa postura de passividade e total alheamento, inconsciente inclusive da sua incapacidade de coincidir consigo próprio (a rima do segundo verso com o quarto recria o contraste entre a figura do Deus "agente" e a do herói "inconsciente", enquanto a do primeiro com o terceiro reitera o caráter "involuntario" de todo começo humano, relacionando-o com o caráter "vario" do herói, diverso e descentrado até de si mesmo).

\footnotetext{
${ }^{18}$ GARCEZ, 1989. p.97-8n.
} 
Coerentemente com o tom de impessoalidade e alheamento desse discurso, os dois únicos verbos desta estrofe ("ser" e "assistir") não exprimem ação e aparecem na terceira pessoa do singular do presente do indicativo.

$\mathrm{Na}$ segunda estrofe, os dois primeiros versos fazem ouvir uma outra voz que, amenizando o tom impessoal, dirige-se ao herói, tratando-o com certa intimidade (na segunda pessoa do singular). $\mathrm{O}$ "enjambement" do primeiro com o segundo verso contribui para realçar o movimento de debilitação do herói, debilitação esta que é igualmente operada no plano sintático, pelo início da estrofe com a oração subordinada, deslocando-se a principal para o segundo verso. Com efeito, esse que, sendo apresentado, desde o início, como um herói, deveria ser um super-sujeito, senhor de seus atos e das suas conseqüências para os outros homens, mantém-se passivo e alheio: a espada que empunha como sua e que deveria ser, para ele, um instrumento de poder e ação, é “achada" em suas mãos, não está ali por iniciativa sua. Note-se que a ação indicada pelo verbo que finaliza o segundo verso (“desce”), refere-se apenas ao movimento descendente do seu olhar. Mais do que essa espada, que ele olha sem saber a que se destinará, ele próprio é apresentado como um instrumento de desígnios supremos e desconhecidos.

A terceira estrofe, constituída por um só verso, possui dois verbos, ambos no pretérito perfeito do indicativo; o primeiro, um transitivo direto, na segunda pessoa do singular e na voz ativa ("Ergueste"), exprime a ação do herói; o segundo ("fez-se"), na terceira pessoa do singular e na voz passiva, modifica o sentido dessa ação, deslocando-a para outro agente e conferindo-lhe uma dimensão transcendente. Consubstancia-se, assim, na própria linguagem poética, o papel reservado ao homem, que, embora 
em estreita afinidade e unidade com a divindade e com as coisas à sua volta, não age como sujeito, é simples "persona", ator de um drama, cujo roteiro é regido por desígnios desconhecidos e que o superam inteiramente.

Naturalmente, variam as interpretações sobre o sentido dessa polifonia. Maria Helena Nery Garcez, por exemplo, assim o analisa:

"É como se, algumas vezes, o épico onisciente se dignasse a ler-nos e a interpretar-nos a História de Portugal e da Humanidade, outras vezes precisasse dirigir-se à figura focalizada para revelar-lhe a ela e a nós o seu papel na mesma História e ora cedesse a voz à própria personagem, porque esta já se encontrasse num grau de iniciação suficiente para ter consciência do lugar que lhe coube no plano divino."19

Já Carlos Felipe Moisés interpreta a plurivocidade no sentido de uma “... sugestão do desencontro, da harmonização difícil e da perda de rumos que se sucederam ao apogeu de Portugal”, sendo em função desse desencontro que as vozes diversas “... convergem alternadamente para o mar, símbolo primordial, catalisador da
alma portuguesa, e para a figura mítica de d. Sebastião, que morreu para além
do mar, no norte da África, no ápice da glória de Portugal como nação sobe-
rana, e poderá voltar também pelo mar. Com isso, a origem do mito sebastia-
nista se confunde com o imaginário marítimo, conferindo algum sentido à
frase enigmática do início do livro, que descreve o Ocidente como 'futuro do
passado.,." Não é o caso de se tentar conciliar essa diversidade de interpretações. Afinal, estamos tratando com uma poética que faz da plurissemanticidade um valor intencional, e, por conseguinte, nada mais esperável e legítimo do que uma variedade de pontos de vista.

Além dos recursos estilísticos diversos, acima mencionados, a abertura semântica desses poemas é promovida pelo movimento oximoresco, que aí se destaca

\footnotetext{
${ }^{19}$ GARCEZ, 1989. p.97-8n.

${ }^{20}$ MOISÉS, C. F 1996.p.59.
} 
como um princípio construtivo primordial, como é ressaltado por Roman Jakobson, em sua análise do poema "Ulysses".

A menção a Jakobson traz à tona um ponto decisivo, que é preciso comentar: a natureza do vínculo que preside o movimento dos oxímoros na poesia de Fernando Pessoa.

Segundo Jakobson, trata-se de "oxímoros dialéticos", conceito que, como observa José Augusto Seabra, não parece contemplar o verdadeiro sentido dessas oposições, tão caras a Fernando Pessoa. Tomando por base o próprio verso — “O mytho é o nada que é tudo" [3] —, que inicia o citado poema pessoano, argumenta Seabra, a meu ver com bastante propriedade, que há, no caso, “... mais do que uma unidade de contrários, uma sua perfeita identidade”: a afirmação de que “... o 'nada' é ‘tudo" implica “... a reversibilidade das oposições pela sua subsistência numa só realidade poemática." 21

Esse é um ponto de fato axial não apenas para a compreensão do poema em apreço, mas de toda a obra poética pessoana, pois, com efeito, o que nela se salienta é uma identidade e reversibilidade dos opostos, cuja consequiência hermenêutica é a de uma flagrante indeterminação, portanto, de uma impossibilidade cognoscitiva: tudo / nada; ser / não ser; verdade / mentira; saber / não-saber, apresentam-se, em praticamente todo o discurso poético pessoano, como valores permutáveis e identificados, colocando em suspenso qualquer juízo definitório.

${ }^{21}$ SEABRA, 1974. p.41-42. 


\title{
5.30 "teatro estático"
}

Segundo a definição dada por Fernando Pessoa, "teatro estático" ou "drama estático” é aquele “... cujo enredo dramático não constitui ação — isto é, onde as figuras não só não agem, porque nem se deslocam nem dialogam sobre deslocarem-se, mas nem sequer têm sentidos capazes de produzir uma acção; onde não há conflito nem perfeito enredo." ${ }^{22}$ Em outras palavras,

\begin{abstract}
“... o enredo do teatro é, não a acção nem a progressão e consequência da acção - mas, mais abrangentemente, a revelação das almas através das palavras trocadas e a criação de situações (...). Pode haver revelação de almas sem acção, e pode haver criação de situações de inércia, momentos de alma sem janelas ou portas para a realidade., 23
\end{abstract}

Dessa modalidade de produção ortônima, escolho comentar os fragmentos de "Primeiro Fausto"24. Mesmo tratando-se de uma produção inacabada, de valor artístico discutível, entendo que não pode ser desconsiderada, pois integra o conjunto das produções do autor. É preciso, sim, considerá-la com a necessária reserva, uma vez que o material apresentado não foi organizado por Fernando Pessoa e sim por seus editores.

O lugar das personagens é aqui ocupado por conceitos personificados e contrapostos em torno de uma questão central: a luta das forças racionais da Inteligência

\footnotetext{
${ }^{22}$ PESSOA, 1973. p.112.

${ }^{23}$ PESSOA, 1973. p.112.

${ }^{24}$ Segundo consta, Pessoa tinha em mente um "Plano dos 3 Faustos", conforme o esquema seguinte: I. "Oposição entre a Inteligência e a Vida"; II. "Oposição entre o Desejo e a Realidade"; III. "Oposição entre Não-Ser e Ser". "A Inteligência busca compreender"; "O Desejo busca possuir (compreender de perto)"; "O Não-Ser busca Ser". (PESSOA, 1977. p.791). Cronologicamente, os fragmentos variam entre 1912 e 1932, tendo sido selecionados e ordenados, primeiramente, por E. F. da Costa, segundo esquema traçado por Fernando Pessoa. Baseio-me nessa seleção e ordenação, que consta de: PESSOA, 1977. p.453-90. Há, entretanto outra seleção e ordenação, feita por Teresa Sobral Cunha e publicada pela Edunicamp.
} 
(representada por Fausto) contra as forças irracionais da Vida (diversamente representada, de acordo com as circunstâncias do drama $)^{25}$, fracassando a primeira, ao tentar dirigir a Vida, ao tentar adaptar-se a ela, ao tentar dissolvê-la. Todo o discurso se desenvolve em torno do anseio de desvendar o "mistério" da existência, "O mistério de tudo ...", "O perene mistério, que atravessa/ Como um suspiro céus e corações..." [545.1:II e III], redundando a indagação fáustica sempre em malogro total. Vendo em tudo um só mistério, doloroso e insolúvel, no qual tudo se esvai, Fausto representa o pólo oposto do objetivismo absoluto de Alberto Caeiro. Observe-se as passagens, que abaixo transcrevo:

[545.1:XXIII]

O mistério do mundo,

O íntimo, horroroso, desolado,

Verdadeiro mistério da existência

Consiste em haver esse mistério.

[545.1:XXVI]

Mais que a existência

É um mistério o existir, o ser, o haver

Um ser, uma existência, um existir [...]

Este é o problema que perturba mais.

O que é existir — não nós ou o mundo -

Mas existir em si?

Alberto Caeiro, como se sabe, manifestando-se totalmente receptivo à evidência sensível, professa uma visão radicalmente objetivista das coisas, eliminando 
qualquer espaço para o mistério: “O mistério das cousas? Sei lá o que é mistério! / O único mistério é haver quem pense no mistério! [210]; “O mistério das cousas, onde está ele?/ Onde está ele que não aparece/ Pelo menos a mostrar-nos que é mistério?” [244]. Paralelamente à recusa do pensamento, das construções elaboradas do espírito, Caeiro recusa a rima, o metro ordenado, elementos que ele tem como falseadores da verdade, dada unicamente pelos sentidos e que deve ser mantida em toda a sua pureza: "O que nós vemos das cousas são as cousas. / Por que veríamos nós uma cousa se houvesse outra? / Por que é que ver e ouvir seria iludir-nos / Se ver e ouvir são ver e ouvir?" [229].

Fausto não pode fazer isto. Representando a Inteligência, ele tem por dever perseguir "A essência inatingível...", que se situa fora do mundo fenomênico e "Furtase até a si mesma" (545.1:XIV).

Ah, tudo é símbolo e analogia!

$O$ vento que passa, a noite que esfria,

São outra coisa que a noite e o vento -

Sombras de vida e de pensamento.

Tudo o que vemos é outra coisa.

A maré vasta, a maré ansiosa,

É o eco de outra maré que está

Onde é real o mundo que há.

Tudo o que temos é esquecimento.

A noite fria, o passar do vento,

São sombras de mãos, cujos gestos são

${ }^{25}$ Cf. PESSOA, 1977. p.789. Segundo esquema deixado pelo poeta, a previsão era de cinco atos: I "Conflito da Inteligência consigo própria"; II "Conflito da Inteligência com outras Inteligências"; III "Conflito da Inteligência com a Emoção"; IV "Conflito da Inteligência com a Ação"; V "Derrota da Inteligência". Sabe-se que, no segundo ato, Pessoa pretendia personalizar a luta da Inteligência para dirigir a Vida, devendo esta última ser representada “... por três discípulos ou outras pessoas” (PESSOA, 1977. p.790). José Augusto Seabra transpõe essa intenção pessoana para o plano da heteronímia , assinalando aí “... mais uma abertura para a abordagem do problema dos heterônimos” (SEABRA, 1974. p.22). 
A ilusão madre dessa ilusão.

Observe-se, no verso interjectivo que inicia o poema, a expressão do desalento de Fausto: "Ah, tudo é símbolo e analogia!". Os verbos "passa" e "esfria", acentuam, no segundo verso, o caráter fugaz dos próprios substantivos a que se referem: "vento" (ar em movimento) e "noite" (espaço de tempo entre o por e o nascer do sol). As rimas emparelhadas reforçam o vínculo analógico entre as coisas: a própria "analogia" rima com "esfria" e "vento" com "pensamento".

Diz o primeiro verso da segunda estrofe: "Tudo o que vemos é outra coisa", ou seja, tudo o que vemos é substitutivo, é simbólico. A coisa mesma é ímpar, transcendente, logo, não pode ser congruente com a "outra" coisa que apenas a simboliza. Talvez por isso, a rima do primeiro com o segundo verso resulte frustrada: a inversão das vogais ("coisa" e "ansiosa") frustra a consonância, chamando a atenção para a incongruência acima referida.

Ainda nesta segunda estrofe, a repetição de palavras merece uma atenção especial. Note-se que "outra", que já aparecera no terceiro verso da primeira estrofe, reaparece no primeiro verso da segunda, debilitando o sentido de permanência do substantivo "coisa" (aquilo que existe ou pode existir) e conferindo-lhe um caráter de irrealidade, de substitutivo: trata-se de uma "outra coisa", que não é a verdadeira. Já no terceiro verso da segunda estrofe, "outra" assume uma conotação oposta, conferindo um caráter de transcendência à "maré" verdadeira, da qual a "maré vasta [...] ansiosa", que conhecemos no plano sensível, não passa de mero "eco". Esse duplo sentido gera tensão, ambigüidade. 
Na terceira estrofe, essa tensão se intensifica. Observe-se que, até o final da segunda estrofe, poder-se-ia pensar numa evocação platônica, de uma verdade extrafenomênica. Agora, essa impressão se desfaz. O que se põe é uma contraposição ao pensamento do filósofo grego. "Tudo o que temos é esquecimento", diz o primeiro verso, não a reminiscência de um mundo verdadeiro. E esse sentido negativo é intensificado nos três versos subsequentes: note-se que, sendo o penúltimo verso mais longo que os demais — é o único decassílabo do poema — seria de se esperar que seu sentido fosse mais amplo, todavia, essa expectativa é frustrada pelo seu "enjambement" com o último verso, do qual depende para completar o seu sentido; ademais, longe de resguardar a verdade daquele mundo real de que fala o último verso da segunda estrofe, o que se põe com esse último verso do poema é uma ampliação do mundo de "ilusão", que ultrapassa as fronteiras do mundo fenomênico e alcança também as "mãos" e os "gestos" supostamente paradigmáticos, despindo-os de sua suposta força veritativa e reduzindo-os a mera “... ilusão madre dessa ilusão.”

Outros recursos apoiam e ampliam o sentido cético que domina esse "drama estático". Por exemplo, as repetições de palavras, dentro do mesmo verso ou da mesma estrofe:

[545.1:XV]

Do eterno erro na eterna viagem,

O mais que [exprime] na alma que ousa,

É sempre nome, sempre linguagem,

$O$ véu e capa de uma outra cousa.

Observe-se neste exemplo, as repetições de palavras: "eterno [...] eterna", “sempre [...] sempre”. São recursos que contribuem para reforçar as noções da eternidade do erro, da insuficiência da palavra (que não revela, antes, vela e encobre, pois é 
sempre "O véu e capa de uma outra cousa"), intensificando o sentimento de decepção, de frustração, de vazio e inutilidade de toda forma de busca.

Mas, se de um lado, não existe certeza, se a busca da verdade é interminável, infinita, mesclando saber e não-saber, por outro, a Inteligência não pode desistir. Em meio à dúvida, à contradição não resolvida, ela se volta sobre si mesma, tenta deslindar seus paradoxos insolúveis, presa pelo próprio fascínio dessa infinitude. Ela sabe que debate em vão, mas mantém-se em estado de busca permanente:

[545.1:X]

O segredo da Busca é que não se acha.

Eternos mundos infinitamente,

Uns dentro de outros, sem cessar decorrem

Inúteis; Sóis, Deuses, Deus dos Deuses

Neles intercalados e perdidos

Nem a nós encontramos no infinito.

Tudo é sempre diverso, e sempre adiante

De [Deus] e Deuses: essa, a luz incerta

Da suprema verdade.

Observe-se, no trecho acima, a ausência de rima, a cadência mais livre, criando um ritmo menos previsível, menos cantante que o dos versos tradicionais. São recursos que acentuam a incerteza que pontua os momentos dessa "Busca", com maiúscula, de uma verdade suprema que se deixa entrever, ao final, por uma "luz incerta". Reforçando a inutilidade de se perseguir algum tipo de apoio e ordenação, o termo ("Inúteis"), que concluiria o sentido do terceiro verso é deslocado para o início do quarto, este, por sua vez, também incompleto e dependente do quinto e do sexto versos, com os quais se encadeia sem pontuação, debilitando a coerência do discurso. No "enjambement" que interliga os três últimos versos, os dois endecassílabos com acentuação variada, corroboram a diversidade e precariedade denunciada no plano dos 
enunciados. Contrastando com os versos longos que o antecedem, o terceiro e último verso desse "enjambement" é o único com apenas seis sílabas poéticas, intensificando assim o caráter débil da "suprema verdade".

O poema subsequente tem uma estrutura inteiramente diversa:

[545.1:XI]

Nos vastos céus estrelados

Que estão além da razão,

Sob a regência de fados

Que ninguém sabe o que são,

Há sistemas infinitos,

Sóis centros de mundos seus,

E cada sol é um Deus.

Eternamente excluídos

Uns dos outros, cada um

É universo.

Compõe-se de três estrofes irregulares: a primeira de seis versos, a segunda de um só verso e a terceira de três. Todos os versos são heptassílabos, exceto o que finaliza o poema, que tem apenas quatro sílabas.

A estrofe de um só verso se destaca espacialmente da primeira e da segunda, embora complete o sentido da primeira e forme uma rima consoante e emparelhada com o seu último verso. As rimas são misturadas. Os quatro primeiros versos obedecem ao esquema de alternância (estrelados e fados; razão e são); o quinto não tem rima, reforçando assim o caráter ilimitado dos "sistemas infinitos"; o sexto verso, como foi dito, rima com o único verso da segunda estrofe (seus e Deus); os três versos da última estrofe são sem rima, o que acentua o caráter de exclusão recíproca de cada um dos sóis e reforça a afirmação de que cada um é um universo inacessível à razão humana. 
A Inteligência não desiste, mantendo sua disposição zetética, inquisitiva, na busca do "Eterno incógnito e incognoscível!".

[545.1:XVI]

Não haverá,

Além da morte e da imortalidade,

Qualquer coisa maior? Ah, deve haver

Além da vida e morte, ser, não ser,

Um inominável supertranscendente,

Eterno incógnito e incognoscível!

Deus? Nojo. Céu, inferno? Nojo, nojo.

Pr'a que pensar, se há de parar aqui

O curto vôo do entendimento?

Mais além! Pensamento, mais além!

A clareza das idéias, a autotransparência da consciência, sobre as quais Descartes fundara a inteira certeza do Cogito, parecem a Fausto, pelo contrário, um lugar de desconhecimento, de incerteza, de obscuridade — "Quanto mais fundamente penso, mais/ Profundamente me descompreendo" [545.2:IV]; "Quanto mais claro/ Vejo em mim, mais escuro é o que vejo" [545.2:XVII]. Voltar-se para dentro de si mesmo, perscrutar as profundezas do seu íntimo, é, inversamente ao que parecera à filosofia do “sujeito pensante”, uma experiência de frustração.

Observe-se a figura insistente do "Quanto mais [...] mais ...", preenchida sempre por paradoxos que reforçam o sentido de frustração da expectativa. Ou então, a fórmula: "Quanto mais [...] menos ...”, mas igualmente preenchida por paradoxos: "Quanto mais compreendo/ Menos me sinto compreendido" [545.2:XVII].

O "vazio cepticismo antigo" não passou de um "Mudo adivinhador", ignaro da “... força toda do que adivinhou..." [545.2:XIII]. Visava a epoché, a paz de espírito, a ataraxia, e a perseguia como se fosse uma meta possível. Para Fausto, pelo contrário, a 
epoché e a disposição zetética não podem conduzir à ataraxia. A suspensão do juízo, a consciência da impossibilidade de conhecer, a atitude de indagação permanente, supõem movimentos especulativos que não podem neutralizar o sentimento paradoxal que sempre acompanha esse tipo de exercício e que se traduz como o "horror de conhecer", ou seja, “ ... horror/ [...] Paradoxal deste pensar...” [545.2:XVII]: "Não é o vício/ Nem a experiência que desflora a alma, / É só o pensamento.../ [...] Só pensar/ Desflora até ao íntimo do ser." [545.2:XXI].

Tal como em Álvaro de Campos, as máscaras são aqui metáforas do caráter ilusório e representativo da existência, do fingimento que acompanha todos os atos e pensamentos, aproximando a vida humana de uma grande peça teatral. A própria dúvida é uma das máscaras a serem arrancadas. Não a última, pois, sob ela, há camadas e camadas de máscaras sucessivas, restando, ao fim ao cabo, um intervalo que jamais se preenche: “Todas as máscaras que a alma humana / Para si mesma usa, eu arranquei — / A própria dúvida, tremendamente, / Arranquei eu de mim, e inda depois / Outra máscara [...] [545.2:XVIII].

“O segredo da busca é que não se acha.” [545.1:X]. Nesse movimento de paradoxos sucessivos, a síntese se mostra impossível, só uma alternância infinita de crença e descrença, verdade e erro, interpenetrando-se e confundindo-se numa permutabilidade contínua, que os esvazia de todo sentido. "Por que pois buscar/ Sistemas vãos de vãs filosofias/ [...] Se o erro é condição da nossa vida,/ A única certeza da existência?/ Assim cheguei a isto: tudo é erro,/ Da verdade há apenas uma idéia/ À qual não corresponde realidade./ Crer é morrer; pensar é duvidar" [545.2:III]. 
Em meio a essa sucessão de contradições não resolvidas, em que os opostos se confundem sem se superarem e sem se contradizerem verdadeiramente, o pensamento tem apenas um destino: buscar e duvidar. Não há conhecimento possível, pois nenhuma totalidade pode abarcar os paradoxos inconciliáveis que compõem a verdade. 


\section{UMA DIALÉTICA SEM SÍNTESE}

Nos capítulos anteriores, a partir do exame de alguns exemplos da poesia ortônima e heterônima, confirmou-se a já sabida pluralidade interna de cada um desses segmentos, bem como o fluxo contínuo de estilos, atitudes e linhas de pensamento que permeia toda a obra poética de Fernando Pessoa.

Sobre o significado desse multifacetamento, dividem-se os críticos e estudiosos de Fernando Pessoa, observando-se, todavia, uma maior recorrência de juízos baseados em pressupostos tendencialmente conciliantes e totalizantes. De acordo com esses pressupostos, o ortônimo e os heterônimos representariam caminhos diversos, pelos quais Fernando Pessoa tentaria ir além da parcialidade e insuficiência das formulações particulares, atingindo uma espécie de síntese poética aglutinadora e conciliadora do maior número possível de pontos de vista sobre o ser e a verdade.

Esse pressuposto, de notório acento hegeliano, subjaz, por exemplo, à explicação oferecida por Massaud Moisés: “O fulcro [...] da cosmovisão pessoana é constituído por um esforço no sentido de conhecer o universo, como um absoluto possível e para além da contingência individual"1. Os heterônimos seriam heterônimos-símbolos de “... visões-matrizes da realidade”, “... cosmovisões arquetípicas [...] nas quais se enquadrariam todas as cosmovisões particulares, incapazes de se expressar como tal", através

\footnotetext{
${ }^{1}$ MOISÉS, M. 1966. p.350.
} 
dos quais, Fernando Pessoa tentaria “... explicar e transcender o caos geral e atingir uma verdade absoluta adentro da floresta de relativismos em que se acha embrenhado ...".2

Também a explicação de Linhares Filho se ancora, e até mais claramente, nessa base hegeliana: o ortônimo e os heterônimos seriam personalidades diversas, pelas quais Fernando Pessoa tentaria lograr “ “... a síntese de uma compreensão e interpretação do universo ...”’3. Seria lógico, então, encarar todas essas personalidades “... como detentoras de teses, que ao mesmo tempo seriam antíteses, tomada cada tese em relação às demais, tudo se encaminhando [...] para a síntese suprema do poético da 'Outra coisa'.,4

Outra leitura fundamentada em pressupostos hegelianos é "O poema e as máscaras", de Carlos Felipe Moisés. Como foi salientado na Revisão da Literatura, entende o citado estudioso que Fernando Pessoa busca, através da heteronímia, “... conhecer a realidade como um absoluto possível, para além das contingências" ${ }^{\prime 5}$, movimentando-se toda a sua poesia em "... circunvoluções concêntricas e espiraladas" relação a esse movimento interno da obra pessoana, o poema "Tabacaria", de Álvaro de Campos, tem um papel simbólico, representando assim, ao mesmo tempo, uma "síntese"

\footnotetext{
${ }^{2}$ MOISÉS, M. 1966. p.350-1.

${ }^{3}$ LINHARES FILHO, 1982. p.24-5.

${ }^{4}$ LINHARES FILHO, 1982. p.36.

${ }^{5}$ MOISÉS, C. F. 1998. p.56.

${ }^{6}$ MOISÉS, C. F. 1999. p.177. (A “espiral” é uma conhecida metáfora do movimento progressivo subentendido pela dialética hegeliana).
} 
e “... um centro receptor e irradiador das linhas de força que percorrem a obra de Pessoa"7 . Em última análise, tudo se passaria

“... como se cada heterônimo, o ortônimo incluído, correspondesse a graus diferentes de uma escala móvel de aproximação da realidade, tarefa inviável para um sistema único e fixo. Desse modo, o conhecimento se ofereceria como projeto exeqüível, não pela coerência interna do sistema, já que muitas das afirmações ou postulados dos heterônimos evidentemente se contradizem, mas pela variedade e abrangência de visões e posturas, levadas a seu limite extremo, como única possibilidade de abarcar o Ser em sua totalidade., 8

Os exemplos desse tipo de concepção são muitos e penso que não é o caso de multiplicá-los. O que estou a questionar é, mais exatamente, o pressuposto que lhes é subjacente, a saber, que o desdobramento de Fernando Pessoa em poetas heterônimos se deveria a uma tentativa de suprir a parcialidade da sua perspectiva particular e lograr uma espécie de verdade-síntese, ou "Verdade-Infinito", semelhante à visada por Álvaro de Campos no seu "Ultimatum". 9

Contra esse pressuposto básico, manifesta-se Leyla Perrone-Moisés, por exemplo, argumentando que, na heteronímia,“... o processo de relacionamento do Um com o Múltiplo segue o modelo hegeliano até certo ponto" ${ }^{\text {10. }}$

\footnotetext{
"Encarar o problema da heteronímia como a manifestação da multiplicidade do Um, é inscrevê-lo num certo hegelianismo, numa filosofia da presença e da totalidade, numa teologia. O Múltiplo, como complementar do Um, constituiria uma alteridade em relação que acabaria por assegurar a unidade do mesmo. O que se passa em Pessoa não é a multiplicação do mesmo em ou-
}

\footnotetext{
${ }^{7}$ MOISÉS, C. F. 1999. p.19.

${ }^{8}$ MOISÉS, C. F. 1999. p.178.

${ }^{9}$ PESSOA (CAMPOS), 1995. p.517-19.

${ }^{10}$ PERRONE-MOISÉS, 1990. p.26.
} 
tros, mas o desencadeamento de uma alteridade tal que a volta ao Um se torna impossível." ${ }^{11}$

A autora levanta, aqui, com toda pertinência, a inadequação de uma leitura de Fernando Pessoa com base no pressuposto hegeliano da complementaridade do um e do múltiplo (do infinito e do finito). De fato, ainda que se tenha em conta que esse princípio está subjacente a muitos momentos do discurso pessoano, notadamente no já tantas vezes citado "Ultimatum", é preciso considerar que a visão de mundo de Álvaro de Campos, ou de qualquer outro componente do universo poético pessoano, inclusive do próprio Fernando Pessoa ortônimo, não eqüivale ao significado que se depreende desse conjunto poético, visto em sua totalidade. Tem razão Leyla Perrone-Moisés quando observa que a heteronímia não se caracteriza como um processo de autodesdobramento dialético, mas como uma "dialética entravada", onde a síntese, a "volta ao Um", é algo de todo impensável.

Um dos pontos que mais se evidenciaram na análise textual foi o intenso movimento oximoresco. Esse movimento, recordando brevemente, mostrou-se particularmente notório no discurso de Fernando Pessoa ortônimo:

\footnotetext{
"Melhor é nem sonhar nem não sonhar / E nunca despertar" [166]; "Dando o que nunca damos." [174]; "O segredo da Busca é que não se acha" [545.1:X]; "Quanto mais fundamente penso, mais/ Profundamente me descompreendo" [545.2:IV]; "Quanto mais claro/ Vejo em mim, mais escuro é o que vejo" [545.2:XVII].
}

E também no discurso do heterônimo Álvaro de Campos:

\footnotetext{
"Depus a máscara, e tornei a pô-la. / Assim é melhor, / Assim sem a máscara. / E volto à personalidade com a um términus de linha" [494]; "Estava bêbado, já não sabia vestir o dominó que não tinha tirado" [456]; "Afinal / Que vida fiz eu da vida? / Nada. / Tudo interstícios, / Tudo aproximações, / Tudo função do irregular e do absurdo, / Tudo nada." [507].
}

${ }^{11}$ PERRONE-MOISÉS, 1990. p.26. 
Em relação a esse jogo de oxímoros, observe-se o seu poder sugestivo e evocativo, a sua capacidade de aflorar significados inacessíveis à linguagem convencional.

Há, de certo um não dito, mas este, como bem alerta Luigi Pareyson, não é tal que esteja a solicitar "explicitação", pois, pelo contrário, pertence àquela classe de discursos que são eloqüentes não tanto pelo que dizem, mas, mais propriamente, pelo que não dizem. E isto porque, se por um lado, instauram um intervalo intransponível entre o dito e o não dito, por outro, abrem a possibilidade de um sentido ulterior, que transforma a própria palavra poética num manancial semântico inesgotável. Citando Pareyson, esse tipo de "não dito" que aí subjaz "...non è un residuo sottinteso che si possa facilmente enunciare, bensí un implicito infinito che alimenta un discorso continuo e senza fine" ${ }^{12}$. Não é, pois, um significado inefável, mas um significado inexaurível, permanentemente aberto a uma infinita gama de reações interpretativas — é nesse sentido que se pode dizer que ele “... non è oggetto ma origine del pensiero, $[. .$.$] non conte-$ nuto ma fonte dei contenuti..." ${ }^{\text {13 }}$. Nesse caso, não se trata de "desmascarar", mas de interpretar, aprofundar o explícito em busca dos significados que ele próprio contém e anuncia.

Retomemos um dos versos já analisados no capítulo sobre a poesia do ortônimo; justamente aquele que é objeto da controvérsia de José Augusto Seabra contra Jakobson: "O mytho é o nada que é tudo" [3]. Não se trata, aqui, como assinala Seabra,

\footnotetext{
${ }^{12}$ PAREYSON, 1994. p.77. T. da A.: “... não é um resíduo subentendido, que possa ser facilmente enunciado, mas, antes, um implícito infinito que alimenta um discurso contínuo e sem fim."

${ }^{13}$ PAREYSON, 1994. p.9. T. da A.: “... não é objeto mas origem do pensamento, [...] não conteúdo mas fonte dos conteúdos...”.
} 
de um "oxímoro dialético". Os termos contrários (nada / tudo) não se fundem numa síntese dialética, mas, mais propriamente, propõem-se como permutáveis.

Do ponto de vista hermenêutico, a conseqüência é, logicamente, uma indeterminação de sentido e não uma síntese dialética. De fato, tanto nesse verso extraído do poema [3], de "Mensagem", como em vários outros, ortônimos e heterônimos, os contrários quase sempre se apresentam como valores permutáveis, reversíveis, acarretando, portanto, uma recíproca debilitação dos seus significados. Observe-se que os pares oximorescos mais freqüentes — ser/ não-ser; ser/ devir; saber/ não-saber; verdade/ mentira; tudo/ nada — vão se alternando. Prevalece, desse modo, a idéia de uma coexistência ambígua, que gera indeterminação de sentido e, por conseguinte, desautoriza qualquer juízo definitório. Em suma, não há uma real superação dos opostos — como seria o caso de uma contradição nos moldes da dialética hegeliana - , mas uma simples coexistência dos contrários.

Isto ocorre também no campo teórico. Veja-se, por exemplo, o trecho em que Fernando Pessoa define o "transcendentalismo panteísta” como “... um sistema essencialmente envolvedor de uma fusão de elementos absolutamente opostos ..."14; ou a sua justificativa quanto ao uso recorrente de paradoxos e "paradoxos contraditórios" em seus textos: trata-se de um procedimento destinado a “... que desde logo o leitor visse claramente, por não ver claramente, em que rede de idéias nos enleamos se queremos

\footnotetext{
${ }^{14}$ PESSOA, 1995. p.397.
} 
distinguir com qualquer espécie de clareza em que fundamentos assentam os conhecimentos." 15

O que aqui está em pauta não é, pois, o alcance de uma verdade-síntese, mas, muito pelo contrário, de um lado, o desvelamento da impossibilidade dessa verdade, do outro, uma tentativa de concretizar na própria palavra, o caráter paradoxal da verdade.

A propósito, é oportuno transcrever o competente juízo de Benedito Nunes, que, já num escrito datado de 1969, ressaltava o fato de Fernando Pessoa ater-se, mais precisamente, à oposição e à identidade dos contrários, e não propriamente à contradição dialética caracteristicamente hegeliana:

\begin{abstract}
"A verdade mesma [...] não corresponde ao conhecimento de uma realidade, seja por meio da intuição, seja pelo encadeamento dedutivo do raciocínio. Ela é, para adotarmos a terminologia atual de certos representantes da filosofia existencial, uma exigência, que se traduz na inquieta demanda do Absoluto, de encontro ao qual se debate o pensamento, cujo destino é buscar e duvidar. Desde que crer implica em descrer, desde que a verdade irrompe como erro e o erro constitui a imagem da verdade, nenhum desses termos supera efetivamente o outro, nenhum deles contradiz o outro. Em vez da negação da negação, síntese dos opostos, temos a identidade dos contrários. Não foi, de fato, a contradição dialética, mas a simples oposição dos contrários e a identidade deles, que Fernando Pessoa aproveitou de suas leituras de Hegel. ${ }^{16}$
\end{abstract}

Em escrito posterior, intervém José Augusto Seabra, comentando que o significado da contradição na poesia de Fernando Pessoa é “... a reversibilidade das oposições pela sua subsistência numa só realidade poemática." ${ }^{17}$

\footnotetext{
${ }^{15}$ PESSOA, 1995. p. 557-8.

${ }^{16}$ Cf. NUNES, 1969. p.238. (A ortografia foi atualizada).

${ }^{17}$ SEABRA, 1974. p.41-42.
} 
De fato, a contradição dialética não se realiza verdadeiramente na obra de Fernando Pessoa. Os múltiplos, os contraditórios, não supõem aí um encaminhamento dialético caracteristicamente hegeliano, antes, mantêm-se como alteridades, decorrendo a sua força expressiva justamente desse seu dialogismo essencial e irredutível.

Um leque de possibilidades equipolentes e dialogicamente articuladas, que remetem reciprocamente umas às outras, entrelaçando-se continuamente, sem encaminhamento sintetizador - eis o que a poesia de Fernando Pessoa nos oferece. E é por isso, justamente, que soa inteiramente falso o propósito de submeter essa plurivocidade a um modelo explicativo conciliador, do tipo pautado na dialética hegeliana, que anula as diferenças reunindo-as em sínteses totalizantes.

É preciso um outro modelo explicativo. E este deve ser tal que não apague nem esvazie a força do conflito, que respeite o papel positivo da diferença, enquanto esta é um elemento constitutivo da própria forma poética criada por Fernando Pessoa.

Dizendo de outro modo, é preciso um modelo hermenêutico diverso, que encare a heteronímia precisamente como ela se apresenta, quer dizer, como lugar de alteridades não suscetíveis de redução ou conciliação.

Para tanto, podem ser de útil contribuição os conceitos bakhtineanos de "dialogismo" e "polifonia". Baseando-nos nesses conceitos, podemos dizer, por analogia, que Fernando Pessoa ortônimo e os heterônimos, além de serem personalidades internamente conflituais, entabulam entre si relações dialogantes, sobre o drama do ser e do conhecimento, sem ter em vista uma conciliação de seus pontos de vista. São, pois, 
facetas dialógicas irredutíveis, que não aceitam se enquadrar numa mecânica fagocitante, do tipo prescrito pela filosofia de Hegel, sob pena de destruir a sua vitalidade expressiva.

Obviamente, não se trata aqui de uma polifonia tradicional, em que as vozes diversas se movimentam livremente, porém unificadas pelo eixo tonal que lhes serve de base. Trata-se de um outro tipo de polifonia, digamos, "atonal", cujo sentido independe de eixos conciliadores. Mais propriamente, os heterônimos se corporizam como entidades autônomas em relação ao seu autor humano, definindo-se como alteridades dotadas de identidade própria, o que acaba por refletir tanto no nível explícito do seu discurso, quanto no plano da articulação interativa dos seus pontos de vista entre si e com Fernando Pessoa ortônimo. Dessa forma, debilitam tanto a idéia de uma hegemonia do autor empírico em relação aos autores ficcionais, quanto a concentração, em um deles apenas, de uma função de porta-voz da Weltanschauung autoral.

De certo, em sua busca incansável, Fernando Pessoa perscruta todos os caminhos possíveis, deixando-se embalar, em um ou outro momento, pelo sonho da reconstituição ou aproximação do absoluto. Nesses momentos, o cultivo da "ideação complexa" de fato se insinua como instrumento conjugador das antíteses fundamentais do conhecimento - subjetivo e o objetivo, o espiritual e o material, o interior e o exterior. Mas, não dura muito tempo. O discurso poético de Fernando Pessoa revela uma índole zetética, distante de soluções apaziguadoras. E com efeito, o que nele acaba por se consubstanciar é a própria impossibilidade de tais soluções: as vozes diversas, ortônima e heterônimas, articulam-se com peso equipolente, sem possibilidade de unificação, configurando-se, em meio a esse debate sem fim, um quadro de plurivocidade, inconclusibilidade e irredutibilidade dialógica, que inviabiliza o sonho romântico/idealista da 
síntese final, para além das contingências individuais. A verdade é paradoxal, sabe ele muito bem, é reunião de contrários, logo, não se deixa capturar na forma de conclusões definitivas.

Isto posto, penso que, a se tentar identificar o fulcro da cosmovisão pessoana, bem antes da hipótese de uma conciliação da sua diversidade intrínseca, coloca-se a reflexão sobre o sentido dessa diversidade como tal.

Não seria este, afinal, o sentido primeiro que nos deixou Fernando Pessoa, qual seja, o de uma polifonia em aberto, capaz de consubstanciar, na própria palavra poética, o paradoxo originário, irredutível e inexaurível, de que se constitui a verdade, e, por conseguinte, a impossibilidade da episteme, entendida como saber especular, absoluto e definitivo?

Naturalmente, tudo isso sugere uma aproximação da poética de Fernando Pessoa ao horizonte reflexivo da filosofia cética. E é aí que pode surgir um aparente embaraço, já que, como confirmou a análise textual dos poemas ortônimos e heterônimos, estes se exibem como verdadeiras defesas de tese, revestindo-se portanto de um cunho afirmativo, incompatível com a epoché que os pirrônicos postulavam como condição para uma legítima atitude cética.

Por outro lado, considerando-se o conjunto formado por esses segmentos diversos de que se compõe a obra poética pessoana, a coisa muda de figura. Lembremonos de que isso é bem compatível com a explicação dada pelo próprio Fernando Pessoa, ao assinalar que, de um lado, a obra de cada heterônimo forma “... uma espécie de dra- 
ma"; do outro, “... todas elas juntas formam outro drama ... ${ }^{, 18}$. Em outras palavras, são planos semânticos diversos, cada qual com seu significado próprio.

A propósito do suposto dogmatismo de certas passagens da prosa pessoana, lê-se em Jacinto do Prado Coelho: "O que acontece é que, de cada vez, [Fernando Pessoa] afirma de modo categórico...", constatando-se, no nível individual dos discursos de cada integrante do universo heteronímico, “...juízos dogmáticos, que podem completarse ou corroborar-se mas podem também contradizer-se"19. Em conjunto, no entanto, conforme prossegue o crítico, essa plurivocidade alcança um significado bem diferente, podendo-se dizer que a sustentação de posições diversas e até antinômicas, em pé de igualdade, oferece ao leitor um horizonte de flagrante indeterminação de sentido, no qual se espelharia “... a própria ambigüidade do mundo." ${ }^{20}$ É verdade que Coelho está a analisar a prosa de Fernando Pessoa, e é nesse sentido que ressalta o caráter ensaístico do seu estilo, caracterizando-o como próprio “... de quem procura na dúvida; não expõe problemas: enuncia factos, princípios, leis, ávido de arrumação e de severa hierarquia". ${ }^{21}$ Penso, contudo, que os pontos fundamentais desse argumento podem ser perfeitamente aplicados ao que ocorre no plano do discurso poético, já que, como disse acima, os poemas ortônimos e heterônimos podem ser vistos como verdadeiras defesas de tese.

Afora o fato de que Fernando Pessoa repudia com veemência a atitude dogmática, qualificando-a como incompatível com o seu perfil pessoal — "Nunca sou dog-

\footnotetext{
${ }^{18}$ PESSOA apud GARCEZ, 1985. p.10.

${ }^{19}$ COELHO, J. do P. Prefácio de PESSOA. 1973, p.XXI.

${ }^{20}$ COELHO, J. do P. Prefácio de PESSOA. 1973, p.XXXI.

${ }^{21}$ COELHO, J. do P. Prefácio de PESSOA. 1973, p.XXI.
} 
mático, porque o não pode ser quem de dia para dia muda de opinião, e é, por temperamento, instável e flutuante",22 —, não é difícil reconhecer que o conceito de verdade que se depreende da sua poesia é inteiramente estranho ao horizonte desse tipo de pensamento. É um valor "impreenchível”, em permanente inadequação com o que pretende designar, um valor “...transferível sempre de horizonte a horizonte, descobrindo-se, a cada passo, como um erro, que outra verdade vem recobrir para novamente transformar-se em erro" ${ }^{23}$. Enfim, um valor que não se deixa alcançar por nenhum dos caminhos trilhados pelo poeta, nem pela via dos encadeamentos dedutivos, nem pela da intuição mística. Em relação à fé, à disponibilidade para com "a verdade eterna", penso que Benedito Nunes tem razão, ao afirmar: “A atitude de Fernando Pessoa [...] está longe dessa adesão participante que caracteriza o espírito do legítimo crente. Ela é dialética até certo ponto, e paradoxal quase sempre. 'Como todos, não creio no que creio' (Barrow-on-Furness, I).” 24

Por outro lado, pode-se objetar que teses diversas e contrastantes se encontram subjacentes à postura poética de cada poeta, ortônimo ou heterônimo, e que as mesmas estão a solicitar visões globalizantes, sintetizadoras.

A meu ver, impõe-se, antes, que essa diversidade seja mantida como tal. Em primeiro lugar, por serem, na maioria das vezes, variações concernentes aos perfis poéticos diversos inventados por Fernando Pessoa para compor a trama caleidoscópica do seu "drama em gente", algumas delas correspondentes a fases cronologicamente distantes da

\footnotetext{
22 PESSOA apud COELHO, J. do P. Prefácio de PESSOA. 1973, p.XXI.

${ }^{23}$ NUNES, 1969. p.237. (A ortografia foi atualizada).

${ }^{24}$ NUNES, 1969. p.237.
} 
sua produção. Em segundo lugar — e isto é o que vejo como mais decisivo —, porque essa pluralidade irredutível possui estreita correlação com a construção polifônica da obra pessoana. É um princípio construtivo de sua obra. ${ }^{25}$

Como foi comentado linhas atrás, já no uso intensivo dos paradoxos, tem-se a consubstanciação, no próprio discurso poético, da visão de Fernando Pessoa sobre o caráter paradoxal da realidade. Tudo isto nos coloca bem longe daquele horizonte especulativo, dominado pelo espectro de uma verdade una, conciliadora, tal como foi sempre visado pelo racionalismo metafísico ocidental. Trata-se, aqui, de uma contraditoriedade essencial, irredutível, que Pessoa postula, pascalianamente, como inerente à própria verdade, enquanto esta é reunião de paradoxos, que não podem submeter-se a sínteses racionais. Estas operam à custa de apagar conflito e, em última análise, de apagar também o diálogo entre os opostos, destruindo, portanto, a sua virulência expressiva.

Há uma outra objeção que se costuma colocar contra a identificação do ceticismo na poética de Fernando Pessoa. Para muitos, isto significaria ignorar a presença de uma vertente mística e esotérica igualmente importante em sua poesia.

Ora, o argumento que se pode aqui interpor é, antes de mais nada, que o ceticismo, enquanto atitude filosófica de radical desconfiança da razão, não inclui, necessariamente, uma negação ou desconfiança das revelações advindas da intuição religiosa.

\footnotetext{
${ }^{25}$ Não se limita a afirmações esparsas, feitas aqui e ali, como, por exemplo: "A suprema verdade que se pode dizer de uma coisa é que ela é e não é ao mesmo tempo. Por isso, pois, que a essência do universo é a contradição [...] uma afirmação é tanto mais verdadeira quanto maior contradição envolve." (PESSOA, 1995. p.393). Ou, em outro lugar: "Tudo quanto existe envolve contradição, porque envolve o ser e o não-ser ao mesmo tempo" (PESSOA, 1995. p.710).
} 
Mesmo no que se refere ao ceticismo antigo, existem estudos recentes que tratam justamente da possibilidade de suspensão do juízo sem suspensão das crenças. ${ }^{26}$

Mais próximos de nós, Montaigne e Pascal são dois conhecidos expoentes do ceticismo na era moderna, difundindo-o nos séculos XVI e XVII, respectivamente. Autores de duros questionamentos contra o racionalismo metafísico - não no sentido de que tenham excluído o exercício da razão, mas de que apontaram os seus limites eles se notabilizaram por sua explícita propensão religiosa. Para ambos, a intuição religiosa se apresentou como um meio privilegiado de superação da insuficiência cognoscitiva do homem. Sendo o homem um ser paradoxal e misterioso e sendo a verdade composta de uma reunião de contrários, nenhum dos dois pode ser explicado pelos procedimentos racionalistas (que passam por cima das contradições e anulam a sua riqueza instigante), apenas pela totalidade da intuição. A fé é o modo de conhecimento próprio do coração, escreveu um dia Pascal, e este tem suas próprias razões, que a razão não pode desacredi$\operatorname{tar}$.

Não há, pois, qualquer conflito entre o misticismo e a atitude cética. Pelo contrário, as duas vias se conjugam e se complementam perfeitamente, podendo-se dizer que, muitas vezes, se realizam como as duas faces de uma mesma moeda. Tanto quanto Montaigne, Pascal e outros pensadores céticos que vislumbraram o caminho da fé como único canal de acesso ao Absoluto, Fernando Pessoa apresenta como fulcro de sua obra a consciência da insuficiência do conhecimento humano, ou seja, de que, pelos sentidos e pela razão, o homem nada pode conhecer com absoluta certeza e segurança, nem a si mesmo nem ao que lhe é externo, restando-lhe a revelação e a graça. Em suma, os ace-

\footnotetext{
${ }^{26}$ Cf. MARCONDES, 1996. p.16.
} 
nos de Fernando Pessoa à Divindade são perfeitamente coerentes com o alcance cético de sua obra. E isto fica ainda mais claro quando se tem presente que, em sua poesia, um dos pontos mais insistentes é a submissão do homem a instâncias e desígnios que o superam inteiramente. Com efeito, ao longo de toda a diversificada trajetória poética de Fernando Pessoa, o que se tem de mais constante é a imagem do homem como “... mero joguete nas mãos de algo que o ultrapassa, seja Deus, seja um simbólico Destino, seja o Acaso e o Imponderável, seja a natureza ambígua de sua própria humanidade (e tudo isso se eqüivale)...." ${ }^{27}$

Como já disse anteriormente, não vejo o misticismo como um veio secundário da poética pessoana, mas como um caminho possível para a meditação de questões cruciais, inacessíveis no âmbito da metafísica racionalista — na impossibilidade de expressar racionalmente a natureza paradoxal da verdade, a expressão dessa contradição deslocar-se-ia para a esfera da fé. Trata-se, então, de um caminho, dentre os vários que ele trilha em sua busca interminável da verdade, não um sentido preeminente de sua poética, nem uma profissão de fé, mas um caminho possível, ao qual ela apela, em virtude da insuficiência dos demais.

Feitas estas ponderações, resta recapitular que essa plurivocidade do "drama em gente" é inerente ao seu próprio modo de estruturar-se. Não é uma resultante de algum equívoco construtivo ou de algum suposto inacabamento acidental. Por isso mesmo, solicita do leitor uma consideração intensivamente ativa e processual, capaz de

${ }^{27}$ MOISÉS, C. F. 1999. p.111. 
percorrer suas faces e interfaces, não para conseguir "visões englobantes", mas para se imergir em sua pluralidade e colhê-la, de per si, como um sentido possível.

O ortônimo e os heterônimos representam visões diversas e equipolentes sobre o problema do ser e da verdade, cujo sentido conjunto não reside neste ou naquele poeta, nesta ou naquela proposição explicitamente enunciada, nem tampouco solicita uma conciliação dialética da sua diversidade, mas, antes, requer que se respeite o seu princípio construtivo multifacetário, colhendo-o tal como se apresenta. Esse horizonte reflexivo, que preside toda a construção da obra pessoana, é bem semelhante ao horizonte dubitativo, inquisitivo e suspensivo, que caracteriza o pensamento dos céticos antigos. Em seu âmago, está a dualidade e equipolência dos opostos, por conseguinte, a impossibilidade de qualquer asserção definitiva. O sentido que assim se impõe é o de uma verdadeira epoché. 


\section{CONCLUSÃO}

Com o objetivo de expor as considerações finais do presente trabalho, cujo tema versa sobre o ceticismo na obra poética de Fernando Pessoa, faço, a seguir, uma breve retomada do itinerário analítico e reflexivo até aqui desenvolvido.

Seguindo os passos estabelecidos no projeto inicial, o primeiro capítulo foi dedicado a uma revisão da literatura crítica sobre Fernando Pessoa, não para oferecer uma relação exaustiva das análises realizadas por outros autores, mas para tentar resumir e comentar alguns resultados alcançados e melhor situar o leitor em relação à minha proposta interpretativa. Comecei pela linha das análises histórico-sociológicas, passando em seguida às análises biográfico-psicanalíticas, às filosóficas e, finalmente, às mais preponderantemente voltadas para a conformação estilística da obra poética pessoana.

Cumprido esse primeiro passo, passei à elaboração do segundo capítulo, também de caráter introdutório, dedicado à exposição dos fundamentos teóricos de minha análise.

Na primeira seção, tratei de dois conceitos pertencentes ao campo da teoria da literatura — polifonia e intertextualidade — nos quais me inspirei em momentos diversos de minha análise. Por serem bastante conhecidos, não dediquei-lhes um tratamento minucioso. Apenas procurei destacar os aspectos que me pareceram mais afins com os procedimentos composicionais empregados por Fernando Pessoa e que me foram de grande valia como estímulo reflexivo sobre sua obra. 
Abordei, em seguida, a questão das relações entre filosofia e poesia, retomando algumas doutrinas mais conhecidas e situando minha posição em relação a elas. No campo das teorias novecentistas, ressaltei a importância decisiva do reconhecimento que Martin Heidegger dedica ao alcance "fundante" da poesia, por ele vista, primordialmente, como origem, inauguração de um significado, e não como documento ou expressão de significados preconcebidos, preexistentes. Nesse mesmo sentido, ressaltei o nome de um outro filósofo contemporâneo, Luigi Pareyson, cujo pensamento estético mostra-se igualmente dedicado ao reconhecimento da ontologicidade da arte e da poesia.

Na terceira seção, procurei destacar o alcance ontológico das poéticas vanguardistas do novecentos, quer dizer, o fato de que sua preocupação auto-expressiva e auto-reflexiva não as confina na esfera do formalismo, mas sinaliza em direção a uma tomada de consciência do alcance fundante da arte. Para tanto, recorri a algumas passagens de Luigi Pareyson, Gianni Vattimo e Umberto Eco, autores que muito insistem sobre o fato de que os produtos dessas poéticas se apresentam como verdadeiras tomadas de posição filosófica sobre a arte. A idéia central, defendida por esses autores, é que, na arte, o modo de formar é, ao mesmo tempo, um modo de ver as coisas e de se posicionar diante do mundo, dispensando a emissão de juízos a respeito do seu objeto de reflexão.

Em particular, procurei destacar as implicações do reconhecimento desse caráter fundante e inaugurante da arte para a leitura e interpretação poética, visando, com isso, esclarecer os pressupostos constantes de minha proposta, a saber, de tomar a obra pessoana não tanto como documento ou expressão de alguma convicção ou sentimento do seu autor, mas, mais especialmente, como fundação de um significado novo, que não 
simplesmente se oferece à explicitação, mas sobretudo é uma fonte inesgotável de reações fruitivas e interpretativas.

Os conceitos centrais da "teoria da formatividade", de Luigi Pareyson, respaldo teórico constante de minha reflexão sobre a dimensão filosófica da poesia pessoana, foram tratados na quarta seção desse mesmo capítulo, sendo precedidos de um delineamento geral da “ontologia hermenêutica", propugnada por esse filósofo. À luz de seus conceitos estéticos, busquei conduzir minha análise no sentido de identificar o ceticismo pessoano não como um significado externo ao qual a forma poética remeteria, mas como um significado consubstanciado com o próprio modo como a mesma se acha configurada. Por se tratar de um pensamento não muito conhecido em nosso meio, dediquei-lhe um comentário mais detido.

Finalizando o capítulo 2, passei em revista alguns desenvolvimentos mais conhecidos da filosofia cética, desde o seu surgimento na Grécia helênica até às teorias relativistas, vigentes à época de Fernando Pessoa. Conforme expliquei desde o início, o escopo de minha pesquisa não foi selecionar idéias de filósofos céticos, para posteriormente identificá-las nos temas e enunciados da poesia pessoana (como se a sua dimensão cética implicasse um prévio conhecimento dessas doutrinas e um aproveitamento textual diretamente extraído de tal ou tal filósofo), mas apenas apontar afinidades entre os dois âmbitos. Nesse sentido, concentrei maior atenção nos aspectos que me pareceram mais afins com a postura poética de Fernando Pessoa, sem me preocupar especialmente com o seu possível conhecimento dessas teorias e se os conceitos por elas propostos estariam diretamente enunciados em sua poesia. 
O terceiro capítulo teve por objetivo oferecer uma visão geral das principais direções estilísticas e filosóficas de Fernando Pessoa. O ponto de referência foi a união de filosofia e poesia no poetar pessoano e a inserção histórica de sua obra na "crise" do racionalismo metafísico. Na seção intitulada "Fernando Pessoa: ‘ ... um poeta estimulado pela filosofia ...", o objetivo foi salientar a perfeita consciência, por parte de Fernando Pessoa, quanto à sua primordial natureza de poeta, quer dizer, quanto ao fato de que, mesmo tendo o profundo dom da especulação, não se reduziria a ser um filósofo com faculdades poéticas, ou seja, aquele cuja obra se limita a simples versificações de conceitos e raciocínios e que, portanto, não é poeta verdadeiro. Na seção seguinte, cujo tema foi a inserção de Fernando Pessoa no horizonte histórico da chamada "crise da razão", apontei alguns aspetos de sua poética, mais afins com o citado contexto. A partir dessa referência de base, teci considerações de caráter geral sobre o sensacionismo, a criação dos heterônimos e o misticismo pessoano, considerados como elementos centrais de sua sintonia com o horizonte epistemológico de incerteza e descrença, gerado pelo declínio do racionalismo metafísico hegeliano.

No quarto capítulo, foram examinados os textos poéticos dos três autores ficcionais que compõem o núcleo heteronímico. A meta precípua foi evidenciar a pluralidade interna de suas obras e seu caráter essencialmente dialógico. Tive em conta, naturalmente, o fato de que, sendo criação pessoal de Fernando Pessoa, os heterônimos se articulam segundo a proposta programática por ele estabelecida, impregnando-se da marca inconfundível de seu autor humano. Todavia, mantive igual atenção ao fato de que o mundo poético multipolar em que se inserem esses poetas ficcionais apresenta-se como uma teia de relações dialógicas e interativas, elaborada mediante uma contrastação de 
"vozes" diversas, que se afirmam em relação ao seu criador como alteridades, ou seja, como entidades autônomas, tanto do ponto de vista estilístico quanto do ponto de vista filosófico, configurando-se, já aí, uma estrutura inequivocamente polifônica.

O quinto capítulo dedicou-se especificamente à poesia de Fernando Pessoa ortônimo, percorrendo alguns textos representativos dos seus três momentos mais caraterísticos — "Cancioneiro", "Mensagem" e "teatro estático". Ao fim desta visita, pareceu-me claro que, por um lado, nenhuma dessas facetas é dominante sobre as demais, por outro, tampouco elas se apresentam como "partes" de um "todo" a ser obtido pela conciliação de suas perspectivas diversas.

A análise textual, realizada no quarto e quinto capítulos, teve por base apenas o que constituiu o núcleo tradicional das primeiras edições da poesia de Fernando Pessoa, evitando os "inéditos", publicados posteriormente, pois, conforme expliquei anteriormente, muitos deles estão lacunários e nem se sabe ao certo se o poeta os considerava aprovados.

No sexto capítulo, teve lugar uma avaliação geral dos resultados das análises textuais realizadas no quarto e quinto capítulos. Os estudos efetuados verificaram a hipótese inicialmente levantada, confirmando-a em seus pontos basilares, a saber:

a) Fernando Pessoa ortônimo e os poetas ficcionais, Alberto Caeiro, Ricardo Reis e Álvaro de Campos, defendem perspectivas possíveis sobre o problema do saber e da verdade, nenhum deles se confirmando como detentor de um posto privilegiado em relação aos demais (naturalmente, isto não significa que os heterônimos saiam do plano estabelecido pelo poeta. Não, a sua autonomia integra justamente esse plano, ou seja, é 
em obediência a esse plano que os heterônimos se afirmam como personalidades independentes);

b) dessa forma, tampouco se legitima a pretensão de alcançar um significado global, através de uma hipotética soma dessas diferentes perspectivas, oferecendo-se, pelo contrário, um jogo de contrastações e diferenças internas inconciliáveis e irredutíveis;

c) essa plurivocidade caracteriza essencialmente o modo de formar pessoano, conferindo à sua obra um alcance eminentemente suspensivo, dubitativo e inquisitivo, o qual é significativamente congruente com o contexto especulativo do ceticismo filosófico, sendo justo entendê-lo como uma verdadeira epoché poética, refratária a qualquer explicação conciliadora; obviamente, esse tipo de ceticismo não concerne à filosofia de vida do homem Fernando Pessoa, mas à filosofia que rege sua poesia e se mostra perfeitamente consubstanciada com o modo como a mesma se configura.

Um ponto que procurei ressaltar, sempre que se fez pertinente essa consideração, foi a perfeita compatibilidade da identificação do ceticismo como nota característica da poética de Fernando Pessoa com o reconhecimento do misticismo que também se faz presente em sua obra. O ceticismo, enquanto atitude filosófica que se caracteriza pela desconfiança da razão, acompanha-se, frequentemente, de um encaminhamento para as revelações advindas da intuição religiosa. Ao longo da história da filosofia, as duas vias muitas vezes se conjugaram e se complementaram, podendo-se mesmo dizer que se realizaram como as duas faces de uma mesma moeda. 
Preocupei-me, igualmente, em salientar que nada disso diminui a relevância do misticismo dentro da poética pessoana, que o apelo místico tem aí um escopo próprio: desvelar um caminho possível para a meditação de questões cruciais, inacessíveis no âmbito da metafísica racionalista. E, para afastar qualquer dúvida, basta lembrar que, se Fernando Pessoa optasse por algum caminho específico, ou mesmo se o recusasse, incorreria numa forma de dogmatismo (afirmativo ou negativo). Aí, sim, não se poderia qualificá-lo como poeta cético. Mas, pelo contrário, todos esses caminhos de busca da verdade compõem um quadro reflexivo de amplo espectro, onde nada é afirmado ou negado com certeza.

Em conformidade com o projeto estabelecido para esta investigação, concentrei-me, primordialmente, nos aspectos construtivos da poesia de Fernando Pessoa, ou seja, naqueles aspectos que definem o seu modo de formar. Esse pressuposto pareysoniano não se mostrou incompatível com a tarefa de avaliar a dimensão filosófica da poesia pessoana. Pelo contrário, justamente pela convicção de que a forma é uma organicidade indivisível, na qual os aspectos estilísticos e semânticos se encontram plenamente consubstanciados, visei colher, na própria configuração formal dessa poesia, o seu legítimo alcance filosófico.

Orientou-me, o tempo todo, o pressuposto de que, se Fernando Pessoa organiza suas formas poéticas polifonicamente, quer dizer, mantendo "vozes" diversas sem submetê-las a qualquer unificação, essa "pluridiscursividade" tem para ele um sentido.

Digo isto porque, na esteira de Luigi Pareyson, acredito que o significado primeiro da poesia (e da arte de modo geral) é aquele que se desenvolve no nível de suas 
formas, quer dizer, no modo de formar, e não nos juízos que profere a respeito de determinado assunto. Assim sendo, se o discurso primeiro da poesia é o que ela faz através do modo de formar e não o veiculado através de simples enunciados e afirmações explícitas, então a avaliação do sentido cético na poesia de Fernando Pessoa remete ao próprio modo como se dispõem as suas formas, e não ao que estas comunicam através de temas e enunciados, isoladamente considerados.

À pergunta contida no título do trabalho, respondo, pois, que Fernando Pessoa é, sim, um poeta cético. E isto porque, dada a peculiaridade da sua estruturação polifônica, dada a situação de equivalência das posições epistemológicas que aí se colocam em jogo, a sua obra coloca o leitor em permanente estado de dúvida, sem outra escolha senão a epoché, a suspensão do juízo, a abstenção de qualquer decisão sobre uma ou outra das posições epistemológicas que diante dele se entrelaçam. 


\section{REFERÊNCIAS BIBLIOGRÁFICAS}

\section{De Fernando Pessoa}

PESSOA, Fernando. Páginas de estética e de teoria e crítica literárias. 2.ed. Lisboa: Edições Ática, 1973. 358p. (Textos estabelecidos e prefaciados por Georg Rudolf Lind e Jacinto do Prado Coelho).

PESSOA, Fernando. Obra poética. 7.ed. Rio de Janeiro: Nova Aguilar, 1977. 842p. (Organização de Maria Aliete Galhoz)

PESSOA, Fernando. Poemas. Rio de Janeiro: Nova Fronteira. 1985. 162p. (Organização de Cleonice Berardinelli).

PESSOA, Fernando. Mensagem. Poemas Esotéricos. Espanha: Archivos / CSIC, 1993. (Edição Crítica coordenada por José Augusto Seabra).

PESSOA, Fernando. Poemas de Ricardo Reis. Lisboa: Imprensa Nacional / Casa da Moeda, 1994. (Edição Crítica organizada por Luís Fagundes Duarte, v. III).

PESSOA, Fernando. Obras em prosa. Rio de Janeiro: Nova Aguilar, 1995. 729p. (Organização de Cleonice Berardinelli).

PESSOA, Fernando. Livro do desassossego. 2.ed. Campinas: Editora da UNICAMP, 1996. $2 \mathrm{v}$.

PESSOA, Fernando. Melhores poemas. 9.ed. São Paulo: Global, 1997. 171p. (Seleção de Teresa Rita Lopes).

PESSOA, Fernando. Álvaro de Campos. Livro de versos. 3.ed. Lisboa: Editorial Estampa, 1997. (Edição crítica organizada por Teresa Rita Lopes: introdução, transcrição, organização e notas). 


\section{Sobre Fernando Pessoa}

ALCÂNTARA, Maria Beatriz Rosário de. Fernando Pessoa e o momento futurista de Álvaro de Campos. Brasília: Fundação Waldemar de Alcântara, 1985.108p.

BARBOSA, Frederico. Pessoa além dos heterônimos. Cult - Revista Brasileira de Literatura. São Paulo, Ano II, p.50-1, jan. 1999.

COELHO, António Pina. Os fundamentos filosóficos da obra de Fernando Pessoa. Lisboa: Editorial Verbo, 1971. 331p.

COELHO, J. do P. Tópicos para uma leitura crítica. In: PESSOA, F. Páginas de estética $e$ de teoria e crítica literárias. 2.ed. Lisboa: Edições Ática, 1973. p.XVI-XXXI. (Prefácio).

COELHO, Jacinto do Prado. Diversidade e unidade em Fernando Pessoa. 5.ed. rev. e atualizada. São Paulo: Verbo/ Edusp, 1977. 299p.

FEITOSA, Márcia Manir Miguel. Fernando Pessoa e Omar Khayyam: o Ruba'iyat na poesia portuguesa do século XX. São Paulo: Giordano, 1998. 214p.

FERRAZ, Heitor. O poeta do exílio. Cult - Revista Brasileira de Literatura. São Paulo, Ano II, p.44-7, jan. 1999.

GAMA, Rinaldo. O drama da linguagem. Cult - Revista Brasileira de Literatura. São Paulo, Ano II, p.40-3, jan. 1999.

GARCEZ, Maria Helena Nery. Alberto Caeiro: "descobridor da natureza"?. Porto: Centro de Estudos Pessoanos, 1985. 211p.

GARCEZ, Maria Helena Nery. Do desconcerto e do concerto do mundo em Mensagem. Estudos portugueses e africanos. Campinas, n.12, jul./dez, 1988, p.1-14.

GARCEZ, Maria Helena Nery. Trilhas em Fernando Pessoa e Mário de Sá-Carneiro: coletâneas de artigos e ensaios. São Paulo: Moraes/ Editora da Universidade de São Paulo, 1989. 136p.

GARCEZ, Maria Helena Nery. O tabuleiro antigo: uma leitura do heterônimo Ricardo Reis. São Paulo: Editora da Universidade de São Paulo, 1990. 103p.

GARCEZ, Maria Helena Nery. Mensagem: profissão de fé poética. Estudos portugueses e africanos. Campinas, n.25/26, jul./dez, 1995, p.159-169.

GARCEZ, Maria Helena Nery. Quinto império e parusia. In: IANNONE, C.A. et al. (Org.) Sobre as naus da iniciação: estudos portugueses de literatura e história. São Paulo: Editora UNESP, 1998. p.95-104. 
GIL, José. Fernando Pessoa ou a metafísica das sensações. Lisboa: Relógio d'Água, [s.d.]. 249p.

GOMES, Álvaro Cardoso. Fernando Pessoa: as muitas águas de um rio. São Paulo: Pioneira/ Editora da Universidade de São Paulo, 1987. 75p.

GOMES, Álvaro Cardoso (Org.). Fernando Pessoa; antologia poética. São Paulo: Moderna, 1996. 152p.

JAKOBSON, Roman. Os oxímoros dialéticos de Fernando Pessoa. In: JAKOBSON et al. Textos selecionados. 2.ed. São Paulo: Abril Cultural, p.119-139, 1978 . (Os Pensadores).

LIND, Georg Rudolf. Teoria poética de Fernando Pessoa. Porto: Editorial Inova, 1970. 350p.

LINHARES FILHO, José. A “outra coisa” na poesia de Fernando Pessoa. Fortaleza: Edições Universidade Federal do Ceará/ PROEDI, 1982. 99p.

LOURENÇO, Eduardo. Fernando Pessoa revisitado; leitura estruturante do drama em gente. Porto: Editorial Inova, 1973. 248p.

MOISÉS, Carlos Felipe. Roteiro de leitura: Mensagem. São Paulo: Ática, 1996. 120p.

MOISÉS, Carlos Felipe. Roteiro de leitura: Poemas de Álvaro de Campos de Fernando Pessoa. São Paulo: Ática, 1998. 136p.

MOISÉS, Carlos Felipe. O poema e as máscaras; introdução à poesia de Fernando Pessoa. 2.ed. rev. atua. Florianópolis: Letras Contemporâneas, 1999. 191p.

MOISÉS, Massaud. Fernando Pessoa: o espelho e a esfinge. 2.ed. rev. aum., São Paulo: Cultrix, 1998. 247p.

NICOLA, José de; INFANTE, Ulisses. Fernando Pessoa. São Paulo: Scipione, 1995. 95p.

NUNES, Benedito. O dorso do tigre; ensaios. São Paulo: Perspectiva, 1969. p.213-262: Os outros de Fernando Pessoa.

PADRÃO, Maria da Glória. A metáfora em Fernando Pessoa. Porto: Editorial Inova, 1973. 215p.

PAVIANI, Jayme. Estética mínima: notas sobre arte e literatura. Porto Alegre: EDIPUCRS, 1996. p.63-77: A modernidade em W. Benjamin e F. Pessoa.

PAZ, Octavio. Os signos em rotação. São Paulo: Perspectiva, 1972. p.201-220: O desconhecido de si mesmo: Fernando Pessoa 
PERRONE-MOISÉS, Leyla. Fernando Pessoa: aquém do eu, além do outro. 2.ed. São Paulo: Martins Fontes, 1990. 159p.

PINTO, Madalena Vaz. A festa da fragmentação. Cult - Revista Brasileira de Literatura. São Paulo, Ano II, p.48-9, jan. 1999.

SACRAMENTO, Mário. Fernando Pessoa: poeta da hora absurda. 2.ed. Porto: Editorial Inova, 1970. 229p.

SEABRA, José Augusto. Fernando Pessoa ou o poetodrama. São Paulo: Perspectiva, 1974. 209p.

SEABRA, José Augusto. O heterotexto pessoano. São Paulo: Perspectiva, 1988. 265p.

SEABRA, José Augusto. Poética e filosofia em Fernando Pessoa. Actas do IV Congresso Internacional de Estudos Pessoanos. Fundação Eng. António de Almeida. v.I, p.401-9.

SEGOLIN, Fernando. Fernando Pessoa: poesia, transgressão, utopia. São Paulo: EDUC, 1992. 163p.

SERRÃO, Joel. Fernando Pessoa: cidadão do imaginário. [s.1.]: Livros Horizonte, 1981. 207p.

SEVERINO, Alexandrino E. Fernando Pessoa na África do Sul. Marília: Faculdade de Filosofia, Ciências e Letras de Marília, 1969-1970. (v.I, 1969; v.II, 1970).

SIMÕES, João Gaspar. Vida e obra de Fernando Pessoa: história de uma geração. 5.ed. rev. e aum. Lisboa: Publicações Don Quixote, 1987. 635p.

SQUEFF, Maria Ozomar Ramos. A filosofia na poesia de Fernando Pessoa. Porto Alegre: Universidade Federal do Rio Grande do Sul, 1980. 111p.

VIEGAS, Sônia Maria de Andrade. A experiência do absoluto em Fernando Pessoa. Boletim do Centro de Estudos Portugueses da Faculdade de Letras da UFMG. Belo Horizonte, ano 1, n.1, junho, 1979, p.21-47. 


\section{De e sobre Luigi Pareyson}

ABDO, Sandra Neves. A autonomia da arte na estética da formatividade. Belo Horizonte: Faculdade de Filosofia da UFMG, 1992. 146p. (Dissertação, Mestrado em Filosofia).

ABDO, Sandra Neves. Arte e historicidade na estética de Luigi Pareyson. Síntese Nova Fase. Belo Horizonte: Edições Loyola, n.69. v.22, 1995, p.193-206.

ABDO, Sandra Neves. Filosofia e história: um falso conflito. Síntese Nova Fase. Belo Horizonte: Edições Loyola, n.79. v.24, 1997, p.547-560.

BAGETTO, Luca. Luigi Pareyson: la realizzazione della libertà. Rivista di estetica, fasc.40-1, p.117-143, 1993.

CARCHIA, Gianni. Esperienza e metafisica dell'arte. L'estetica di Luigi Pareyson. Rivista di estetica, fasc.40-1, p.76-86, 1993.

ECO, Umberto. A estética da formatividade e o conceito de interpretação. In: ECO. A definição da arte. São Paulo: Martins Fontes, 1981, p.13-32.

ECO, Umberto. Le sporcizie della forma. Rivista di estetica, fasc.40-1, p.17-23, 1993.

FERRARIS, Maurizio. Un'estetica senza opere. Rivista di estetica, fasc.40-1, p.87-109, 1993.

PAREYSON, Luigi. Arte e persona. Rivista di Filosofia, fasc. 1-2, p. 18-37, 1946.

PAREYSON, Luigi. Unità della filosofia. Filosofia. Turim: Edizioni di "Filosofia", Anno III, n.I, p.83-96, gen., 1952.

PAREYSON, Luigi. Conversazioni di estetica. Milão: Mursia, 1966. 185p.

PAREYSON, Luigi. Esistenza e persona. Nova ed. Gênova: Il Melangolo, 1985. 294p.

PAREYSON, Luigi. L'esperienza artistica. Milão: Marzorati, 1974. 294p.

PAREYSON, Luigi. Conversaciones de estética. Madri: Visor, 1988. 232p.

PAREYSON, Luigi. Estetica: teoria della formatività. 5.ed. Milão: Tascabili Bompiani, 1991. 337p.

PAREYSON, Luigi. Conversations sur l'esthétique. Paris: Éditions Gallimard, 1992. 220p. (Tradução de Gilles A. Tiberghien. Título original: Conversazioni di estetica).

PAREYSON, Luigi. Verità e interpretazione. 4.ed. Milão: Mursia, 1994. 260p. 
PAREYSON, Luigi. Ontologia della libertà; il male e la sofferenza. Turim: Einaudi, 1995. 478p.

PAREYSON, Luigi. Filosofia da liberdade. Síntese Nova Fase. Belo Horizonte: Edições Loyola, n.72. v.23, 1996, p.75-90. (Tradução de Sandra Neves Abdo. Título original: Filosofia della libertà).

PAREYSON, Luigi. Os problemas da estética. 3.ed. São Paulo: Martins Fontes, 1997. 246p. (1ed. 1984. Tradução de Maria Helena Nery Garcez. Título original: I problemi dell'estetica.).

RAVERA, Marco (Org.) Luigi Pareyson: filosofia dell'interpretzione. Turim: Rosenberg \& Sellier, 1988. 243p. (Antologia de textos).

RUSSO, Francesco. Esistenza e libertà: il pensiero di Luigi Pareyson. Roma: Armando Editore, 1993. 255p.

SARTO, Pablo Blanco. Hacer arte, interpretar el arte; estética y hemenéutica en Luigi Pareyson. Pamplona: EUNSA, 1998. 338p.

VATTIMO, Gianni. Pareyson dall'estetica all'ontologia. Rivista di estetica, fasc.40-1, p.3-16, 1993.

\section{Sobre: ceticismo, epicurismo, estoicismo, relativismo}

ASSOUN, Paul-Laurent. Freud: a filosofia e os filósofos. Rio de Janeiro: Livraria Francisco Alves, 1978.

BRUGGER, Walter. Dicionário de filosofia. São Paulo: Herder, 1962. 703p.

CHÂTELET, François (Org.) História da filosofia: idéias e doutrinas. Rio de Janeiro: Zahar Editores, 1973. 221p. (v.1, A filosofia pagã).

CHÂTELET, François (Org.) História da filosofia: idéias e doutrinas. Rio de Janeiro: Zahar Editores, 1974. (V.2, A filosofia medieval; do século I ao século XV). 232p.

CORRÊA, José de Anchieta. Freud e a ilusão da filosofia da consciência. In: A presença de Freud no mundo contemporâneo. Brasília: Editora da Universidade de Brasília, [s.d].

DELACAMPAGNE, Cristian. História da filosofia no século XX. Rio de Janeiro: Jorge Zahar Editor, 1997. 308p. 
EPICURO et al. Antologia de textos. São Paulo: Abril Cultural, 1973. (Os Pensadores, $\mathrm{V})$.

GIGANTE, Marcello. Scetticismo e epicureismo: per l'avviamento di un discorso storiografico. Nápoles: Bibliopolis, 1981. 244p.

GUIMARÃES, Lívia. Hume entre o academicismo e o pirronismo. Kriterion - Revista de Filosofia. Belo Horizonte, v. XXXV, n.93, p.106-122, jan.-jun.,1996.

HUME, David. Investigação sobre o entendimento humano. São Paulo: Abril Cultural, p.127-198, 1973. (Os Pensadores, XXII).

MARCONDES, Danilo. Juízo, suspensão do juízo e filosofia cética. Kriterion - Revista de Filosofia. Belo Horizonte, v. XXXV, n.93, p.9-21, jan.-jun.,1996.

MONDOLFO, Rodolfo. El genio helénico y los caracteres de sus creaciones espirituales. Tucumán: Universidad Nacional de Tucumán, 1943. 148p.

NUNES, Benedito (Org.). A crise do pensamento. Pará: UFPA, 1994. 206p.

SMITH, Plínio Junqueira. O ceticismo de Hume. São Paulo: Loyola, 1995. 301p. (Filosofia, 32).

SOUZA, José Cavalcante de (Org.). Os pré-socráticos: fragmentos, doxografia e comentários. 2.ed. São Paulo: Abril Cultural, 1978. 365p.

VERDAN, André. Le scepticisme philosophique. Paris: Bordas, 1971. 146p.

WAELHENS, Alphonse De. Inconscient, sujet, verité. Revue Philosophique de Louvain. Louvain, maio, 1974.

HIRSCHBERGER, Johannes. História da filosofia na antigüidade. São Paulo: Herder, 1965. 327p.

HIRSCHBERGER, Johannes. História da filosofia moderna. São Paulo: Herder, 1967. $434 \mathrm{p}$.

NIETZSCHE, F. W. Além do bem e do mal; prelúdio a uma filosofia do futuro. São Paulo: Companhia das Letras, 1992. 


\section{Geral}

ABBAGNANO, Nicola. Diccionario de filosofia. México: Fondo de Cultura Económica, 1986. (11a. reimpressão). 1206p.

ABDALA JUNIOR, Benjamim. História social da literatura portuguesa. São Paulo: Ática, 1982.

AMORA, Antônio Soares. Introdução à teoria da literatura. São Paulo: Cultrix, 1999. $159 \mathrm{p}$.

ARISTÓTELES. Poética. In Aristóteles II. São Paulo: Abril Cultural, 1979. p. 237-310. (Os Pensadores, IV).

BAKHTIN, Mikhail. Problemas da poética de Dostoiévski. 2.ed. rev. Rio de Janeiro: Forense Universitária, 1997. 275p.

BARROS, Diana Luz Pessoa; FIORIN, José Luiz (Org.). Dialogismo, polifonia, intertextualidade: em torno de Bakhtin. 2.ed. São Paulo: EDUSP, 1999. 81p.

BOSI, Alfredo (Org.). Leitura de poesia. São Paulo: Ática, 1996. (p.7-48: Sobre alguns modos de ler poesia: memórias e reflexões).

BOSI, Alfredo. O ser e o tempo da poesia. São Paulo: Cultrix, 1977. 220p. (Cap. 1, 2, 3, p.11-107).

BOSI, Alfredo. Céu, inferno; ensaios de crítica literária e ideológica. São Paulo: Ática, 1988. 287p. (Cap.: A máquina do mundo: entre o símbolo e a alegoria, p.80-95).

BRAS, Gérard. Hegel e a arte: uma apresentação à Estética. Rio de Janeiro: Jorge Zahar Editor, 1990. 149p.

BRUNEL, Pierre (Org.) Dicionário de mitos literários. Rio de Janeiro: José Olympio, 1997. 939p.

CAMPOS, Haroldo de. A arte no horizonte do provável. São Paulo: Perspectiva, 1976.

CAMPOS, Maria José R. Arte e verdade. São Paulo: Loyola, 1992. 134p.

CÂNDIDO, Antônio et al. A personagem de ficção. 9.ed. São Paulo: Perspectiva, 1995. 119p. (Debates, 1)

CANDIDO, Antonio. Na sala de aula: caderno de análise literária. 7.ed. São Paulo: Ática, 1999. 95p.

CROCE, Benedetto. Breviário de estética. 9.ed. Madri: Espasa Calpe, 1985. 142p. 
CUNHA, Antônio Geraldo da. Dicionário etimológico Nova Fronteira da língua portuguesa. 2.ed. Rio de Janeiro: Nova Fronteira, 2001. 839p. (14a. impressão. Edição revista e acrescida de um Suplemento).

DERRIDA, Jacques. L'écriture et la différence. Paris: Éditions du Seuil, 1967.

DESCARTES, René. Discurso do método. São Paulo: Abril Cultural, 1973. (Os Pensadores, XV).

DUFRENNE, Mikel. Estética e filosofia. São Paulo: Perspectiva, 1981. 266p.

DUFRENNE, Mikel. A estética e as ciências da arte: o estudo actual dos principais problemas estéticos e das diferentes artes. Lisboa: Livraria Bertrand, 1982. 248p. (v2)

ECO, Umberto. A estrutura ausente: introdução à pesquisa semiológica. São Paulo: Perspectiva, Editora da USP, 1971. 426p. (Estudos, 6).

ECO, Umberto. As formas do conteúdo. São Paulo: Perspectiva, 1974. 184p. (Estudos, 25).

ECO, Umberto. Obra aberta: forma e indeterminação nas poéticas contemporâneas. São Paulo: Perspectiva, 1976. 288p. (Debates, 4).

ECO, Umberto. A definição da arte. São Paulo: Martins Fontes, 1981. 281p.

ECO, Umberto. Lector in fabula: a cooperação interpretativa nos textos narrativos. São Paulo: Perspectiva, 1986.

ECO, Umberto. Arte e beleza na estética medieval. 2.ed. Rio de Janeiro: Globo, 1989. $224 p$.

ECO, Umberto. Semiótica e filosofia da linguagem. São Paulo: Ática, 1991.

ECO, Umberto. Interpretação e superinterpretação. São Paulo: Martins Fontes, 1993. $183 \mathrm{p}$.

FABRIS, A. Futurismo: uma poética da modernidade. São Paulo: Perspectiva/ Edusp, 1987. (Estudos, 94).

FERRY, Luc. Homo aestheticus. Paris: Grasset, 1990. 470p.

FISCHER, Ernst. A necessidade da arte. 9ed. Rio de Janeiro: Zahar Editores, 1983. $254 \mathrm{p}$.

FIZ, Simón Marchán. La estética en la cultura moderna. Madri: Alianza Forma, 1992. 270p. 
FOCILLON, Henri. Vida das formas. Rio de Janeiro: Zahar Editores, 1983. 156p.

FORMAGGIO, Dino. Arte. Lisboa: Editorial Presença, 1985. 160p.

FRANÇA, J. L. et al. Manual para normalização de publicações técnico-científicas. 5.ed. rev. Belo Horizonte: Ed. UFMG, 2001. 211 p.

FREUD, Sigmund. Uma dificuldade no caminho da Psicanálise. In: História de uma neurose infantil e outros trabalhos. Rio de Janeiro: Imago, v.XVII, p.175-8, [C.1969].

FREUD, Sigmund. O ego e o id. Rio de Janeiro: Imago, 1975. 81p.

GADAMER, Hans-Georg. Verdad y método; fundamentos de uma hermenéutica filosófica. Salamanca: Ediciones Sígueme, 1977.

GIVONE, Sérgio. Historia de la estética. Madri: Tecnos, 1990. 316p.

GOLDSTEIN, Norma. Versos, sons, ritmos. 11.ed. São Paulo: Ática, 1999. 80p.

GRASSI, Ernesto. Arte como antiarte. São Paulo: Duas Cidades,1975. 291p.

HAUSER, Arnold. História social da literatura e da arte. 3.ed. São Paulo: Mestre Jou, 1972. 1193p. (Tomo II)

HEGEL, Georg W. Friedrich. Esthétique; textes choisies. Paris: PUF, 1954. 227p.

JAPIASSU, Hilton. Nascimento e morte das ciências humanas. 2ed. Rio de Janeiro: Francisco Alves, 1982. 262p.

KANT, Immanuel. Crítica da razão pura. São Paulo: Abril Cultural, 1980. 415p. (Os Pensadores).

KANT, Immanuel. Crítica da faculdade do juízo. 2.ed. Rio de Janeiro: Forense Universitária, 1995. 384p.

LAMANNA, E. Paolo. Historia de la filosofía. Buenos Aires: Hachette, 1957. 410p. (v. I, Filosofía de la Antigüedad).

LANCEROS, Patxi. Apunte sobre el pensamiento destructivo. In: VATTIMO, Gianni et al. En torno a la posmodernidad. Barcelona: Anthropos, 1994. p.137-59.

LANGER, Susanne K. Ensaios filosóficos. São Paulo: Cultrix, 1971. 161p.

LUIJPEN, W. Introdução à fenomenologia existencial. São Paulo: EPU, Ed. Da Universidade de São Paulo, 1973. 400p. 
MERLEAU-PONTY, Maurice. Signos. São Paulo: Martins Fntes, 1991. 392p.

MOISÉS, Massaud. A literatura portuguesa. 4.ed. São Paulo: Cultrix, 1966.

NUNES, Benedito. O drama da linguagem. São Paulo: Ática, 1989. 175p.

NUNES, Benedito. Introdução à filosofia da arte. São Paulo: Buriti, 1991. 128p.

NUNES, Benedito. A filosofia contemporânea: trajetos iniciais. São Paulo: Ática, 1991. $142 p$.

NUNES, Benedito. Passagem para o poético: filosofia e poesia em Heidegger. 2.ed. São Paulo: Ática, 1992. 304p.

NUNES, Benedito. No tempo do niilismo e outros ensaios. São Paulo: Ática, 1993. 199p.

OLIVEIRA, Maria Eugênia Dias de. O texto dentro do texto: "O nome da rosa" e a enciclopédia semântica medieval. Kriterion. Belo Horizonte: Departamento de Filosofia da Faculdade de Filosofia e Ciências Humanas da UFMG, v.XXX, jul/87 - jun/88, p.103-189.

REIS, C.; LOPES, A. C. Dicionário de narratologia. Coimbra: Almedina, 1987.

RICOEUR, Paul. De l'interprétation; essai sur Freud. Paris: Seuil, 1965. 575p.

RICOEUR, Paul. Le conflit des interprétations: essais d'herméneutique. Paris: Seuil, 1969. 501p.

SARAIVA, A. J.; LOPES, O. História da literatura portuguesa. 17.ed. corr. e atual. Porto: Porto Editora, 1996. 1216p.

SCHELLING, F. W.J. Le système de l'idéalisme transcendental. Louvain: Éditions Peeters, 1978. 270p.

SOURIAU, Etienne. A correspondência das artes: elementos de estética comparada. São Paulo: Cultrix / Ed. da USP, 1983. 271p.

SUBIRATS, Eduardo. Da Vanguarda ao pós-moderno. 2.ed. São Paulo: Nobel, 1986. $110 \mathrm{p}$.

TATARKIEWICZ, Wladyslaw. Historia de seis ideas: arte, belleza, forma, creatividad, mímesis, experiencia estética. 3.ed. Madri: Tecnos, 1992. 422p.

TELES, Gilberto Mendonça. Vanguarda européia e modernismo brasileiro: apresentação dos principais poemas, manifestos, prefácios e conferências vanguardistas, de 1857 a 1972. 6a ed. rev. e aum. Petrópolis: Vozes, 1982. 448p. 
VALlEJO, A.; MAGALHÃES, L. C. Lacan: operadores da leitura. São Paulo: Perspectiva, 1981. 169p.

VATTIMO, Gianni. Etica de la interpretación. Buenos Aires: Paidos, 1992. 224p.

VATTIMO, Gianni. Poesia e ontologia. Nova ed. aum. Milão: Mursia, 1985. 207p.

WEYRAUCH, Célia S.; VINCENZI, Lecticia B. (Org.). Moderno e Pós-Moderno. Rio de Janeiro: UERJ, 1994. 86p. 